UNIVERSIDADE DE SÃO PAULO - FEUSP

SÔNIA REGINA GUARALDO

A FORMAÇÃO CONTÍNUA EM SERVIÇO: UM ESTUDO DAS REPRESENTAÇÕES DE PROFESSORES E GESTORES EM TRÊS MUNICÍPIOS PAULISTAS

SÃO PAULO - SP

2015 
SÔNIA REGINA GUARALDO

\section{A FORMAÇÃO CONTÍNUA EM SERVIÇO: UM ESTUDO DAS REPRESENTAÇÕES DE PROFESSORES E GESTORES EM TRÊS MUNICÍPIOS PAULISTAS}

Dissertação de Mestrado - versão reformulada - apresentada ao Programa de Pós-Graduação da Faculdade de Educação da Universidade de São Paulo para obtenção do título de Mestre em Educação.

Área de concentração: Didática, Teorias de Ensino e Práticas Escolares.

Orientadora: Prof. ${ }^{a}$ Dr. ${ }^{a}$ Sonia Teresinha de Sousa Penin

\section{SÃO PAULO - SP}

2015 
AUTORIZO A REPRODUÇÃO E DIVULGAÇÃO TOTAL OU PARCIAL DESTE TRABALHO, POR QUALQUER MEIO CONVENCIONAL OU ELETRÔNICO, PARA FINS DE ESTUDO E PESQUISA, DESDE QUE CITADA A FONTE.

Catalogação na Publicação

Serviço de Biblioteca e Documentação

Faculdade de Educação da Universidade de São Paulo

371.12

G914f
Guaraldo, Sônia Regina

A formação contínua em serviço: um estudo das representações de professores e gestores em três municípios paulistas / Sonia Regina Guaraldo; orientação Sonia Teresinha de Sousa Penin. São Paulo, s. n., 2015.

216 p.; grafs.; tabs.; anexos

Dissertação (Dissertação - Programa de Pós-Graduação em Educação - Área de Concentração: Didática, Teorias de Ensino e Práticas Escolares) - Faculdade de Educação da Universidade de São Paulo.

1. Representações 2. Formação continuada de professores 3. Prática de ensino 4. Autonomia I. Penin, Sonia Teresinha de Sousa, orient. 


\section{Banca Examinadora}

Prof $^{\mathrm{a}} \mathrm{Dr}^{\mathrm{a}}$ Sonia Teresinha de Sousa Penin - Instituição: FEUSP

Prof $^{\mathrm{a}}$ Dr $^{\mathrm{a}}$ Elba Siqueira de Sá Barreto - Instituição: FEUSP

Prof $^{a}$ Dr $^{a}$ Bernardete Angelina Gatti - Instituição: Fundação Carlos Chagas

São Paulo, 09 de setembro de 2015

Aprovado em 
Ao meu marido Paulo e aos meus filhos Júlia e Bernardo. 


\section{Agradecimentos}

A Deus, por me conceder a graça de realizar este trabalho e por me dar força e coragem nos diversos momentos de dificuldade.

À Prof ${ }^{a}$ Dr $^{a}$ Sônia Teresinha de Sousa Penin, pela atenção, pelo apoio e pelas palavras sábias na orientação deste trabalho.

Às professoras Doutoras Elba Siqueira de Sá Barreto e Bernadete Angelina Gatti, por terem gentilmente aceitado participar da banca de defesa de minha dissertação e pelas orientações no exame de qualificação.

Ao Professor Doutor Fábio Mariano da Paz, pelas conversas e pelo incentivo, iluminando caminhos e contribuindo com o trabalho em diversos momentos.

Às professoras Andréa Ramos e Eudóxia Aparecida da Silveira Símaro, pela cuidadosa revisão do texto original.

Aos diretores, coordenadores, professores e gestores de formação contínua dos Sistemas A, B e C, pela inestimável colaboração.

Às minhas queridas sobrinhas Ana Clara Costa e Isabela Maria da Costa, pela doce presença e acolhimento nesse período de estudo.

A toda minha família e a todos os amigos que me ajudaram e apoiaram ao longo desta jornada.

Aos profissionais do ensino da Secretaria Municipal de Educação de Birigui, pelo constante diálogo sobre formação contínua que muito contribuiu para a formulação das reflexões tecidas neste estudo. 
Pois quantos são os modos em que se diz, tantos são os significados do ser. Aristóteles 
GUARALDO, Sônia Regina. A FORMAÇÃO CONTÍNUA EM SERVIÇO: Um estudo das representações de professores e gestores em três municípios paulistas. Dissertação (Mestrado em Educação - Faculdade de Educação - USP - Universidade de São Paulo, São Paulo-SP, 2015.

\section{RESUMO}

Esta pesquisa apresenta um estudo das representações sobre formação contínua de profissionais da gestão e da docência em três municípios do interior paulista, a partir da perspectiva teórica da antropologia dialética de Henri Lefebvre. Tendo como principal objetivo desvendar que representações sobre formação contínua possuem os sujeitos envolvidos na pesquisa, confrontam-se neste estudo a análise dos dados obtidos através da realização de entrevistas com gestores escolares e municipais, a análise das manifestações obtidas através da aplicação de questionário tipo survey com todos os professores das séries iniciais do ensino fundamental, além dos dados coletados a partir da realidade socioeconômica e educacional observada nos municípios dos quais fazem parte as redes de ensino municipal pesquisadas, em especial os dispositivos formais de incentivo à participação na formação contínua previstos em lei, os índices educacionais obtidos nas últimas avaliações censitárias em larga escala, como também as propostas de formação contínua desenvolvidas nos anos de 2012 e 2013. A partir da análise individual e comparativa dos dados obtidos nas três redes de ensino, a investigação aponta para a influência que as diferentes representações de gestores e professores, confrontadas especialmente ao contexto educacional dos sistemas de ensino, exercem uns sobre os outros, modificando-se. Nesse sentido, observa-se que nos contextos em que o conjunto de ações de formação contínua é provido em maior quantidade e, presumivelmente, em melhor qualidade, os professores tendem a representar a capacitação profissional em serviço como fonte de conhecimento pedagógico com vistas à melhoria da prática e os gestores a demonstrar maior grau de envolvimento e autonomia na condução desses programas.

Palavras-chave: Representações, Formação Contínua, Prática Pedagógica, Autonomia 
GUARALDO, Sônia Regina. CONTINUING EDUCATION IN SERVICE: a study of teachers and managers representations in three counties. Dissertation (Master of Education - Faculty of Education - USP - University of São Paulo, São Paulo-SP, 2015.

\begin{abstract}
This research presents a study of the representations about the continuing education of professionals of management and teaching over three municipalities in the countryside of the State of São Paulo, from the theoretical perspective of Henri Lefebvre's dialectical anthropology. Having as its main goal to unveil which representations of continuing education have the subjects involved on the research, the following aspects are confronted along the investigation: the data analysis obtained through interviews with school managers and city managers; the analysis of the survey answered by all teachers of the first years of elementary school; and data collected from socioeconomic and educational realities observed in the municipalities which are part of the teaching system surveyed, especially the formal incentive tools of continuing education provided by the law, the educational indexes obtained during the latest census evaluation in large scale, as well as proposals of continuing education developed in 2012 and 2013. From the individual and comparative analysis of the data obtained in the three teaching networks, the investigation points the influence that different representations of managers and teachers, especially confronted with the educational context of the teaching system, exert to each other, modifying themselves. In this sense, it is observed that in the contexts where the set of education actions is provided in larger quantity and, presumably, in better quality, teachers tend to represent the professional capacity as a source of pedagogical knowledge in order to improve the practice and the demonstration, by managers, of a bigger level of involvement and autonomy in the conduction of these programs.
\end{abstract}

Keywords : Representations, Continuing Formation, Pedagogical Practice, Autonomy 


\section{Lista de figuras}

Figura 1 Organograma atual da Secretaria de Educação-

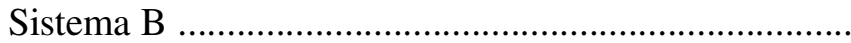




\section{Lista de Gráficos}

Gráfico 1 Distribuição das matrículas de ensino fundamental

$\left(1^{\mathrm{a}}\right.$ a $4^{\mathrm{a}}$ série$)$ dependência administrativa do estado de São Paulo, 1996 - 2001

Gráfico 2 Distribuição das matrículas de ensino fundamental (anos iniciais) dependência administrativa do estado de São Paulo, 2005 - 2014

Gráfico 3 Movimento das matrículas na rede municipal de 1999 a 2013.

Gráfico 4 Movimento das matrículas na rede municipal de 1999 a $2013 .$.

95

Gráfico 5 Movimento das matrículas na rede municipal de 1999 a

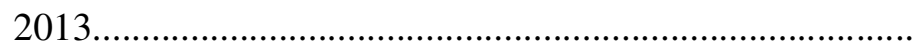




\section{Lista de Quadros}

Quadro 1 Objetivos e Eixos da entrevista com gestores municipais e

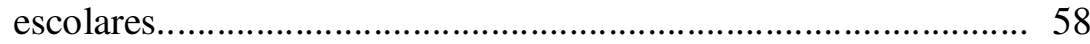

Quadro 2 Resultado do IDEB - Sistema A............................................ 65

Quadro 3 Estrutura de organização da Secretaria de Educação do

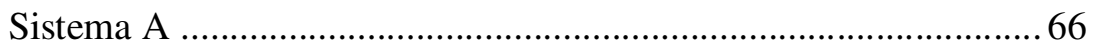

Quadro 4 Programas de Formação Contínua previstos na jornada de trabalho dos professores do Sistema A …..................................... 69

Quadro 5 Atribuições no processo de formação contínua referentes aos cargos do magistério público municipal ...................................... 70

Quadro 6 Metas e ações para a formação continuada dos profissionais da educação do Sistema A ................................................................. 72

Quadro 7 Principais temas/áreas apontados para a abordagem na formação

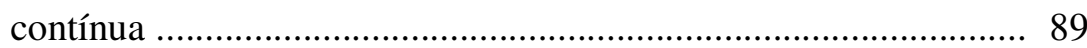

Quadro 8 Resultado do IDEB - Sistema B ........................................... 96

Quadro 9 Programas de Formação Contínua previstos na jornada semanal de trabalho dos professores do Sistema B .................................... 99

Quadro 10 Resultado do IDEB - Sistema C ........................................... 122

Quadro 11 Composição do quadro do magistério público municipal -

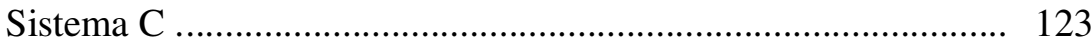

Quadro 12 Programas de Formação Contínua previstos na jornada semanal de trabalho dos professores do Sistema C

Quadro 13 Principais aspectos de interferência na formação profissional nos Sistemas A, B e C 


\section{Lista de Tabelas}

Tabela 1 Questionários enviados e devolvidos ....................................... 56

Tabela 2 Dados sócio-econômicos do município........................................ 63

Tabela 3 Fatores que mais motivam a participação nos cursos oferecidos... 83

Tabela 4 Porcentagens referentes à participação caso a formação não fosse contada para a progressão funcional.......................................... 85

Tabela 5 Frequência de participação manifesta pelos professores do Sistema A........................................................................... 86

Tabelas 6 Percentuais de formação em nível de pós-graduação manifestos pelos professores ................................................................... 86

Tabela 7 Relevância da formação contínua para o enfrentamento dos desafios pedagógicos ................................................................... 90

Tabela 8 Principais contribuições à construção de conhecimento pedagógico............................................................................ 91

Tabela 9 Dados sócio-econômicos do município............................................. 94

Tabela 10 Fatores que mais motivam a participação nos cursos oferecidos... 110

Tabelas 11 Percentuais de formação em nível de pós-graduação manifestos pelos professores …............................................................... 112

Tabela 12 Principais temas/áreas apontadas para a abordagem na formação

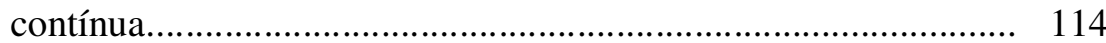

Tabela 13 Relevância da formação contínua para o enfrentamento dos desafios pedagógicos ............................................................... 115

Tabela 14 Principais contribuições à construção de conhecimento

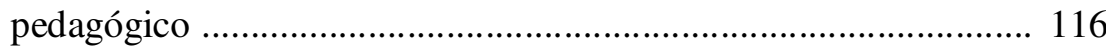

Tabela 15 Dados sócio-econômicos do município ....................................... 120

Tabela 16 Fatores que mais motivam a participação nos cursos

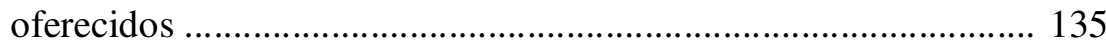

Tabela 17 Percentuais de formação em nível de pós-graduação manifestos

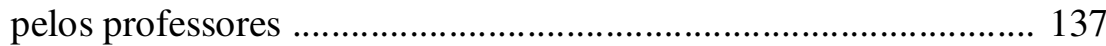

Tabela 18 Principais temas/áreas apontadas para a abordagem na formação contínua .................................................................... 140

Tabela 19 Relevância da formação no enfrentamento dos desafios

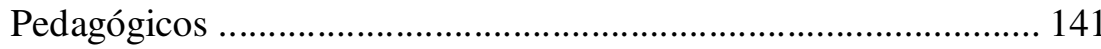


Tabela 20 Principais contribuições à construção de conhecimentos

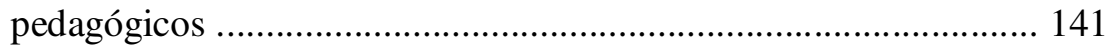




\section{Lista de Siglas}

\begin{tabular}{|c|c|}
\hline $\mathrm{BM}$ & Banco Mundial \\
\hline CPSA & Coordenador Pedagógico do Sistema A \\
\hline CPSB & Coordenador Pedagógico do Sistema B \\
\hline CPSC & Coordenador Pedagógico do Sistema C \\
\hline EMEI & Escola Municipal de Educação Infantil \\
\hline EMEF & Escola Municipal de Ensino Fundamental \\
\hline FUNDAP & Fundação de Desenvolvimento Administrativo \\
\hline FUNDEB & $\begin{array}{l}\text { Fundo de Manutenção e Desenvolvimento da Educação Básica e } \\
\text { Valorização do Magistério }\end{array}$ \\
\hline FUNDEF & $\begin{array}{l}\text { Fundo de Manutenção e Desenvolvimento do Ensino } \\
\text { Fundamental e Valorização do Magistério }\end{array}$ \\
\hline GMSA & Gestor Municipal do Sistema A \\
\hline GMSB & Gestor Municipal do Sistema B \\
\hline GMSC & Gestor Municipal do Sistema C \\
\hline GESA & Gestor Escolar do Sistema A \\
\hline GESB & Gestor Escolar do Sistema B \\
\hline HEC & Hora de Estudo Coletivo \\
\hline HTP & Hora de Trabalho Pedagógico \\
\hline НТРC & Hora de Trabalho Pedagógico Coletivo \\
\hline НТРP & Horas de Trabalho no Desenvolvimento de Projetos e Pesquisas \\
\hline HTPFC & Hora de Trabalho Pedagógico de Formação Contínua \\
\hline IDEB & Índice de Desenvolvimento da Educação Básica \\
\hline INEP & Instituto Nacional de Estudos e Pesquisas \\
\hline LDB & Lei de Diretrizes e Bases \\
\hline MEC & Ministério da Educação \\
\hline PDE & Plano de Desenvolvimento da Educação \\
\hline PISA & Programa Internacional de Avaliação de Alunos \\
\hline PNAIC & Pacto Nacional pela Alfabetização na Idade Certa \\
\hline PNE & Plano Nacional de Educação \\
\hline PPP & Projeto Político Pedagógico \\
\hline PPPI & Projeto Político Pedagógico Institucional \\
\hline
\end{tabular}


PREAL Programa de Promoção das Reformas Educativas na América Latina

OCDE Organização para Cooperação e Desenvolvimento Econômico

SARESP Sistema de Avaliação do Rendimento Escolar de São Paulo

SEADE Fundação Sistema Estadual de Análise de Dados

SEE/SP Secretaria de Educação do Estado de São Paulo 
SUMÁRIO

INTRODUÇÃO....................................................................................................... $\quad 20$

PARTE I

1. A FORMAÇÃO CONTÍNUA DE PROFESSORES: Responsabilidades

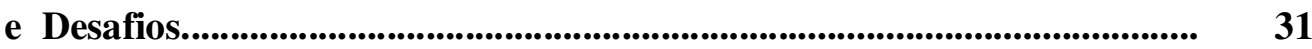

1.1. Os novos paradigmas na formação docente ................................................ 33

1.2. Os sistemas municipais e a responsabilidade pela formação contínua de professores

2. A TEORIA DAS REPRESENTAÇÕES DE HENRI LEFEBVRE: UMA POSSIBILIDADE DE COMPREENDER AS CONCEPÇÕES E PRÁTICAS DOCENTES SOBRE FORMAÇÃO....................................... 46

3. METODOLOGIA: INSTRUMENTOS DE PESQUISA, COLETA E ANÁLISE DOS DADOS........................................................................... 52

3.1. Fonte de dados e critérios de análise .................................................... 54

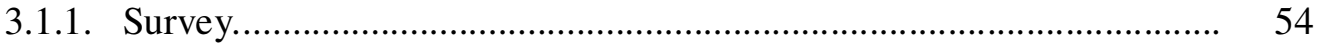

3.1.2. Entrevista semi-estruturada ….......................................................... 57

3.1.3. Análise de documentos ....................................................................... 59

3.1.4. Análise de Conteúdo..................................................................... 60

PARTE II - OS SISTEMAS DE ENSINO: AS RELAÇÕES ENTRE CONTEXTO E REPRESENTAÇÕES ................................................ 62

4. O SISTEMA A .................................................................................... 63

4.1. Contexto sócio-econômico, Estrutura da Secretaria Municipal de Educação e Plano de Carreira ............................................................................ 63

4.2. A proposta de Formação do Sistema A....................................................... 73

4.3. Representações sobre Formação Contínua............................................. 77

4.3.1. Representação sobre Formação Contínua pelos gestores municipais...... 78

4.3.1.1. Formação Contínua como responsabilidade de outrem......................... 78

4.3.2. Representações sobre Formação Contínua pelos professores da rede...... 82

4.3.2.1. Fatores que mais motivam a participação na Formação Contínua......... 83 
4.3.2.2. Expectativas sobre a Formação Contínua e sua relevância para a prática.

4.4. A falta de autonomia na condução das ações de formação contínua e o foco nas vantagens profissionais

92

\section{O SISTEMA B}

5.1. Contexto sócio-econômico, Estrutura da Secretaria Municipal de Educação e Plano de Carreira ............................................................................ 94

5.2. A proposta de Formação do Sistema B................................................... 99

5.3. Representações sobre Formação Contínua ................................................... 103

5.3.1. Representação sobre Formação Contínua pelos gestores municipais....... 103

5.3.1.1. Formação Contínua como meio de melhoria nos resultados das

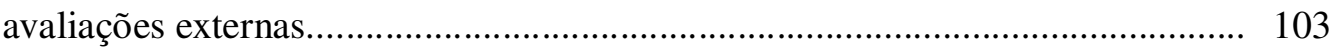

5.3.1.2. Formação Contínua como responsabilidade de outrem ......................... 107

5.3.2. Representações sobre Formação Contínua pelos professores da rede ....... 109

5.3.2.1. Fatores que mais motivam a participação na Formação Contínua ......... 109

5.3.2.2. Expectativas sobre a Formação Contínua e sua relevância para a Prática.

5.4. As Representações sobre formação contínua e o foco na prática pedagógica

6. O SISTEMA C

6.1. Contexto sócio-econômico, Estrutura da Secretaria Municipal de Educação e Plano de Carreira

6.2. A proposta de Formação do Sistema C 126

6.3. Representações sobre Formação Contínua 129

6.3.1. Representação sobre Formação Contínua pelos gestores municipais

6.3.1.1. Formação Contínua como meio de melhorar os resultados do Sistema..

6.3.1.2. Formação Contínua como responsabilidade de outrem

6.3.2. Representações sobre Formação Contínua pelos professores da rede 131

6.3.2.1. Fatores que mais motivam a participação na Formação Contínua 134

6.3.2.2. Expectativas sobre a Formação Contínua e sua relevância para a Prática

6.4. Um cenário incerto, marcado por contradições. 
7. TRÊS SISTEMAS: SINGULARIDADES, REGULARIDADES E ALGUNS CAMINHOS........................................................................................... 145

CONSIDERAÇÕES FINAIS ............................................................................... 156

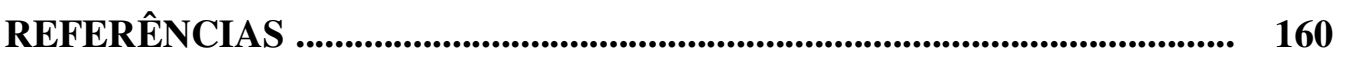

ANEXOS............................................................................................................... 166 


\section{INTRODUÇÃO}

A necessidade de realizar esta pesquisa sobre as representações dos professores referentes à formação contínua em serviço surgiu a partir do interesse em compreender o poder exercido por essas representações nos processos de capacitação profissional, considerando a maneira como os profissionais do ensino se apropriam dos conhecimentos e os introduzem em suas práticas, bem como a influência que as diversas configurações educacionais exercem sobre essas representações, modificando-as e sendo por elas modificadas.

Desde o início de nossa trajetória profissional, já sentíamos na prática a problemática da formação contínua, cujos desafios - enfrentados tanto na docência como na gestão das redes estadual, particular e municipal - sempre estiveram presentes. $\mathrm{Na}$ coordenação pedagógica da rede estadual, os desafios eram decorrentes da indefinição de identidade que sofria o cargo, que se configurava como um misto entre inspetor de alunos/auxiliar do diretor e formador. Mesmo entendendo a necessidade de que as ações de formação incidissem diretamente na melhoria da prática docente, não se dispunha, na época, dos saberes necessários e condições estruturais e organizacionais que permitissem a realização de um trabalho de formação com essas características.

A atuação docente na rede particular de ensino durante onze anos trouxe uma experiência de formação profícua, aproximando os estudos à prática concreta dos professores. Ainda que se percebesse certa hierarquização entre teoria e prática, os estudos teóricos, realizados individual e coletivamente, propunham experiências em sala de aula e registros reflexivos acerca de estudos e práticas realizadas. Mesmo considerando as limitações e possibilidades da proposta, essa experiência de formação representou grande avanço na maneira de compreender a importância da adequada relação entre teoria e prática, de se privilegiar a escola como lócus de formação e da necessária presença de uma assessoria técnica que dê conta de gerir de forma equilibrada a capacitação profissional, a fim de garantir ao mesmo tempo a qualidade da formação e a autonomia da escola durante o processo.

$\mathrm{O}$ ingresso na rede municipal de ensino possibilitou a vivência da formação contínua a partir de uma nova ótica. A experiência como Dirigente Municipal de Ensino trouxe, assim como as enormes responsabilidades, os desafios de oferecer formação para os professores da rede em meio a um contexto no qual havia um grande caminho a percorrer, a fim de proporcionar uma capacitação profissional com vistas à melhoria da 
prática através da geração de conhecimento pedagógico. O trabalho realizado junto à equipe da secretaria de educação aconteceu a partir de uma perspectiva que contemplasse a formação de uma equipe pedagógica composta por profissionais efetivos da rede e que pudessem, de forma gradativa, pensar a formação a partir da escola, com o envolvimento dos professores e desenvolvendo mecanismos eficazes que garantissem o real avanço dos saberes docentes.

Os propósitos nada modestos requereram durante esses anos uma série de aprendizagens dos profissionais formadores, já que o que se pretendeu desde o início foi intervir na maneira de pensar a formação de professores, vista por grande parte dos docentes com base em uma concepção transmissiva e com foco nas progressões funcionais.

$\mathrm{O}$ interesse em estudar mais profundamente como professores e gestores agem e concebem as práticas de formação de professores e o despertar do entendimento da pesquisa como uma maneira de compreender a realidade para agir sobre ela foram em parte despertados pelo curso de pós-graduação latu sensu denominado Escola de Gestores, estruturado pelo Ministério da Educação em parceria com a Universidade Federal de São Carlos - UFSCAR. O curso, desenvolvido na modalidade semipresencial, tinha como objetivo a realização de estudos e execução de tarefas voltadas para o diagnóstico da realidade escolar e propostas de intervenção com base nos problemas observados.

Os estudos realizados de forma mais sistemática, as mudanças em relação à concepção de formação docente do grupo profissional do qual faço parte, bem como as ações necessárias a serem empreendidas para que os processos de formação contínua continuem se aperfeiçoando, fizeram com que, exercendo a função de secretária de educação ou o cargo efetivo de diretora de escola, sentisse necessidade de refletir mais profundamente sobre os mecanismos que podem fazer com que a capacitação de professores cumpra seu papel na melhoria da qualidade da educação pública oferecida.

Dessa forma, pesquisar como outros municípios articulam sua formação de professores, captando representações de seus profissionais a esse respeito, pode não só nos levar a identificar em que medida a gestão municipal ou escolar interfere na maneira de pensar e agir em relação aos processos de formação contínua, também, a partir da percepção do outro, pode nos levar a ver a nós mesmos, de modo que o rigor da pesquisa ofereça dados mais objetivos da realidade da qual fazemos parte: a educação pública municipal. 
A questão central deste estudo é descobrir quais representações possuem os professores do ensino fundamental e gestores escolares e municipais de três redes municipais de ensino do interior paulista a respeito da formação permanente, tendo como cenário principalmente o contexto educacional ao qual estão submetidos em seus respectivos municípios.

Ao analisar as representações desses sujeitos, contextualizadas em suas realidades particulares, pretendemos demonstrar como veem a formação continuada em serviço oferecida pelos respectivos sistemas de ensino, buscando compreender como pensam esse importante elemento das atuais políticas educacionais. Apreendendo essas representações, buscaremos elementos para avaliar como tais propostas se refletem no cotidiano desses professores e podem estar conduzindo sua postura diante da formação profissional.

Pesquisar as representações dos profissionais da educação sobre formação em serviço torna-se relevante ao nos fornecer elementos sobre como as políticas de formação praticadas pelos sistemas de ensino pesquisados têm sido determinadas por contextos mais amplos, presentes no atual cenário educacional brasileiro, como é o caso das avaliações externas, que tem representado para alguns daqueles que conduzem as políticas públicas de educação os únicos parâmetros norteadores de suas ações.

Dessa forma, interessa-nos também conhecer representações dos professores e gestores a respeito da formação contínua a fim de identificar nelas que conceitos as definem, considerando os novos paradigmas sobre o tema em decorrência das novas configurações de sociedade trazidas pelo século XXI e suas mudanças na forma de entender a tarefa de educar.

$\mathrm{O}$ interesse em conhecer como os profissionais que atuam na docência representam diversos temas voltados à área da educação tem sido alvo de inúmeras investigações no Brasil e no exterior.

Procurando conhecer as pesquisas que investigam a temática da formação de professores sob a ótica desses profissionais, realizamos um levantamento dos antecedentes teóricos sobre o tema. Dentre os objetivos identificados nessas pesquisas, destacaram-se, além da identificação de concepções e representações sobre formação contínua, da avaliação de impacto de propostas de formação, a análise de modalidade e o formato das capacitações oferecidas. Ainda assim, na investigação sobre tais antecedentes, procuramos identificar nas metodologias utilizadas aquelas que buscavam captar representações, olhares e concepções desses profissionais, mesmo que tais 
pesquisas tivessem objetos diferentes e não se utilizassem diretamente de referenciais teóricos idênticos ao priorizado no presente trabalho.

André (2009) indica um aumento significativo das pesquisas no campo da formação de professores nos últimos anos. Segundo o mapeamento realizado por ela, na década de 1990, o volume de pesquisas que tinham como foco a formação de professores era de $7 \%$, tendo atingido $22 \%$ em 2007. Segundo a autora, a mudança ocorrida não envolve só a quantidade, mas também seus objetos de estudo. “(...) nos anos 2000, o foco dirige-se ao (à) professor (a), aos seus saberes, às suas práticas, às suas opiniões e às suas representações, chegando a 53\% do total de estudos". Ainda em suas palavras

Um aspecto muito promissor das pesquisas mais recentes é a atenção dada ao professor. Muitos estudos foram produzidos nos últimos anos, em torno das opiniões, das representações, dos processos de constituição de identidade, dos saberes e práticas dos professores. Conhecer de perto quem é o professor da educação infantil, da educação básica ou superior parece-nos não só relevante, mas fundamental para que se possam delinear estratégias efetivas de formação. Aproximar-se das práticas dos professores, adentrar o cotidiano de seu trabalho é, sem dúvida, imprescindível para que se possa pensar, com eles, as melhores formas de atuação na busca de uma educação de qualidade para todos (ANDRÉ, 2009, p.4)

Um dos pontos mais discutidos nas pesquisas investigadas é aquele que avalia seus impactos quanto à mudança de postura do professor nas ações pedagógicas que desenvolvem. As pesquisas de Altobelli (2008) e Bauer (2011) apontam para uma mudança na concepção e nas ideias sobre alfabetização, mas a falta de acompanhamento, dentre outros fatores apontados, impede que tais ideias sejam incorporadas de fato ao trabalho com os alunos.

Tal conclusão também é observada no estudo de Valiengo (2012). Tendo como objetivo analisar as representações dos professores capacitados nos programas Letra e Vida (SP/Brasil) e Programa Nacional de Ensino de Português (Portugal), a pesquisa descreveu o entendimento dos impactos proporcionados em suas atuações pedagógicas após capacitações ocorridas nos Programas de Formação. À semelhança dos estudos citados, a autora também aponta novas concepções incorporadas ao discurso dos professores, que afirmam ter modificado sua prática após a capacitação e, embora aponte algumas rotinas veiculadas no curso, como a leitura diária na sala de aula e a identificação das hipóteses de escrita das crianças, sugere que essa avaliação, por parte dos professores, não representa uma modificação no modo de ensinar. 
Embora a autora reconheça a iniciativa de formação por parte dos governos como algo positivo, sinaliza que tais ações parecem ser insuficientes para a modificação qualitativa de práticas educativas envolvendo processos de ensino e aprendizagem de leitura e escrita. Revela carência de estudos sobre as melhores maneiras de se realizar uma formação continuada, já que é notória a necessidade de tê-la no processo em que o profissional se torna alfabetizador.

Lellis (2003) destaca diversas mudanças detectadas a partir do olhar do professor. $\mathrm{O}$ estudo analisou os resultados obtidos através da observação e preenchimento de questionários por parte de vinte professores durante a participação em um curso de formação para o ensino de ciências.

O trabalho procurava responder a duas questões centrais: 1- Até que ponto um curso nesses moldes pode contribuir para uma efetiva mudança - em direção a uma menor fragmentação dos conhecimentos - na concepção que o professor tem a respeito dos conteúdos de ciências? 2 - Que tipos de mudanças podem acontecer na visão e na atitude dos professores em relação à sua própria prática pedagógica a partir de uma intervenção desse tipo?

A autora observa, através da fala desses profissionais, o reconhecimento de novas atitudes em sua forma de trabalhar, novas abordagens metodológicas em relação ao conteúdo e postura de iniciativa frente a novas formas de trabalho, além de maior interesse e participação por parte dos alunos.

Sugere, ainda, que o curso interferiu na concepção que os professores tinham sobre o conteúdo de ciências, mas ressalta que a análise foi realizada a partir das próprias observações da pesquisa ao longo do curso e dos relatos dos professores, não havendo outros dados coletados em sala de aula. Ainda assim, considera os resultados favoráveis, uma vez que o objeto da pesquisa era a mudança nas concepções do professor a respeito do conteúdo, sendo este, na visão da pesquisadora, um primeiro passo para a mudança, apontando, ao mesmo tempo, fatores limitantes de caráter institucional presentes no cotidiano do professor.

Finaliza o trabalho reconhecendo as limitações presentes numa formação continuada com caráter isolado, sugerindo a própria escola como espaço de formação, além de uma reestruturação geral do sistema educativo, passando por melhoria salarial e diminuição da carga horária.

Ao utilizar-se da abordagem metodológica da teoria das representações sociais de Serge Moscovici, Nunes (2010) analisa o discurso dos professores de uma escola 
pública comunicando-se, através de cartas, com professores em processo de formação inicial. Nesse estudo, tendo como dados as narrativas sobre formação docente, procura detectar o conhecimento que ambos os grupos julgam ser importantes para sua atuação profissional e sobre o papel que assumem no processo de apropriação de conhecimentos pelos alunos/as sob sua responsabilidade.

A análise das referidas cartas procurou desvendar, através das narrativas sobre os cursos de formação docente, as representações sobre o que é ser professor, através do modelo social de professor, das atitudes em relação à formação docente e das informações a respeito dos conhecimentos necessários ao cumprimento das funções docentes.

Em sua análise, a autora chama a atenção à postura dos professores durante os cursos de formação. Mesmo os mais experientes encontram dificuldade em abandonar a postura de estudante durante esses momentos, revelando, segundo ela, uma representação social sobre formação que enxerga o formador como portador de verdades universais. Aponta como consequência certa hierarquização no modo de enxergar a questão teoria e prática. Conformam a teoria veiculada à sua utilização prática, ou a utilização da teoria na prática, o que, segundo a autora, as distancia ainda mais. Quando analisa as representações sobre como veem o trabalho pedagógico e o papel do aluno diante da aprendizagem, essa ideia se confirma. Ao chamar atenção ao que Buker (2001) denomina pedagogia diretiva, concebe o aluno num papel passivo diante das ações de aprender e o professor como transmissor de conhecimentos.

Sugere uma formação de professores que compreenda que os sujeitos sempre vão reconstruir aquilo que será tomado como objeto do conhecimento, devendo, assim, incidir na mudança das representações sociais, através de alterações pequenas, operadas no cotidiano e nas relações estabelecidas com o convívio social, mas que são ponto de partida para a adesão ou implementação de propostas que darão conta dos desafios. E conclui:

A possibilidade de mudanças significativas na prática pedagógica vai se dar quando às mudanças nas representações coincidirem transformações nas condições concretas onde essas vão ser ancoradas. É praticamente impossível fazer coincidir o discurso em uma realidade que o nega sistematicamente (NUNES, 2010).

Mendes (2008) utiliza-se também da teoria das representações sociais para analisar a visão de professores de uma escola da rede municipal de Presidente Prudente 
sobre um momento destinado à formação de professores naquela cidade, o HTPC Hora de Trabalho Pedagógico Coletivo". Intitulado "HTPC: Hora de Trabalho Perdido Coletivamente", o trabalho conclui, a partir da análise das representações desses professores, que eles desejam aprender, mas consideram que esse momento não tem atingido seus objetivos. Falta-lhes clareza sobre o que seria um trabalho coletivo, e de que forma a existência desses momentos semanais de formação poderiam fortalecer o trabalho em equipe. Para eles, a postura dos gestores e a forma de participação dos professores não têm gerado mudanças significativas na prática pedagógica.

A autora atribui essa avaliação dos professores, principalmente, à organização desses momentos na escola. Segundo ela, o contexto das políticas em relação à formação permanente não tem garantido os elementos possibilitadores para a existência de oportunidades de estudo mais proveitosas, uma vez que tais momentos são permeados pela falta de diretrizes e objetivos, coordenados por gestores que se pautam, ao mesmo tempo, pela liberdade excessiva e pelo autoritarismo na sua condução.

Aponta como caminho a ampla discussão em contexto municipal baseada na literatura existente sobre as modalidades e tipos de formação, a fim de que esse conhecimento seja incorporado às políticas educacionais do município, assegurando espaços de estudos que ajudem a esclarecer aos profissionais da educação a proposta de formação centrada na escola e a forma como pode ser conduzida. Inclui, dentre outras proposições, a efetivação da gestão democrática, incluindo o fortalecimento do papel do Orientador Pedagógico e a consolidação dos momentos de HTPC como espaços reais de formação e trabalho em equipe, tendo deles excluídas as atividades improdutivas e burocráticas.

Sem utilizar-se do marco teórico das representações, Assis (2014) aborda o tema da formação de professores. Procura desvelar o olhar de onze professores atuantes em uma escola da rede municipal de Araçatuba, objetivando especificamente analisar um programa de formação contínua dessa rede, o HTPP - Horas de Trabalho no Desenvolvimento de Projetos e Pesquisas ${ }^{2}$ e, na visão desses professores, que impactos estaria gerando para uma melhor atuação em sala de aula.

\footnotetext{
${ }^{1}$ Horário instituído através da aprovação do Estatuto do Magistério - Lei no 79/99. A partir de então, os professores de Educação Infantil e do Ensino Fundamental passaram a ter em sua carga horária no mínimo 4 horas-atividade para serem realizadas em local de livre escolha e 4 horas de trabalho pedagógico coletivo semanal para serem realizadas na escola.

${ }^{2} \mathrm{O}$ Programa é parte integrante da jornada do professor para o qual são destinadas duas horas, além de outras duas destinadas ao HTPC - Hora de Trabalho Pedagógico Coletivo. O HTPP tem por finalidade a
} 
A problemática que leva a autora à pesquisa se dá no pressuposto de que as atuais políticas de formação de professores não têm gerado os benefícios educacionais esperados na melhoria da qualidade de ensino.

A pesquisa de abordagem qualitativa detectou um posicionamento favorável dos professores em relação à existência e aos impactos do programa na rede, pois ele favorece um espaço privilegiado para discussões e socialização das dificuldades e aprimoramento profissional, mas, segundo sua percepção, há uma má organização do tempo que, embora restrito, não é utilizado de maneira eficaz e em sua totalidade.

A partir do posicionamento dos professores em relação aos aspectos discutidos pela pesquisadora, foi possível desvendar sua concepção em relação ao que definem como formação contínua. A autora conclui que, embora se posicionem favoravelmente em relação aos seus benefícios para a melhoria educacional, mantêm um discurso revelador de pressupostos da racionalidade técnica, já que não se colocam como sujeitos de sua própria formação, atribuindo a alguém externo essa responsabilidade.

Os docentes envolvidos na pesquisa destacam, ainda, a falta de articulação e comunicação entre a escola e os gestores municipais, ressaltando que, após a consolidação do programa HTPP, criado com o propósito de promover o desenvolvimento profissional e melhorar qualitativamente a educação, não se verificou por parte da Secretaria Municipal de Educação indícios de ações de acompanhamento ou avaliação do programa.

Sugere, por fim, uma aproximação e maior presença dos gestores municipais na definição das ações de formação, com base nas reais necessidades das instituições, apontando como condição indispensável a organização de políticas que garantam condições estruturais, organizacionais, administrativas e pedagógicas minimamente planejadas e articuladas entre si para que o programa cumpra, de fato, o que propõe.

Não encontramos pesquisas que abordassem especificamente, através da perspectiva teórica de Henri Lefebvre, a análise das representações de professores sobre formação continuada, tendo como cenário o cotidiano determinado pelas políticas públicas.

Encontramos, dessa forma, diversas pesquisas que se utilizavam da teoria das representações de Henri Lefebvre, como a realizada por Almeida (2012) que analisou as representações docentes no ensino médio sobre leitura, escrita e aprendizagem por

elaboração e efetivação de projetos de pesquisa, a articulação com a comunidade e o aperfeiçoamento profissional. 
competências no currículo do Estado de São Paulo, e muitas delas abordando diversos temas no campo da geografia.

Entendemos, assim, que a pesquisa que nos dispusemos a realizar traz como contribuição a possibilidade de olhar o campo da formação continuada através das representações de professores e gestores pela perspectiva dialética de Lefebvre, que oferece as condições de entendê-las a partir das políticas determinadas por diretrizes nacionais como também aquelas observadas na realidade particular das cidades analisadas.

A nosso ver, a análise das realidades únicas de cada sistema de ensino pesquisado é que nos traz a chance de entender a força do cotidiano nas representações sobre formação de professores e de que forma interfere no modo de sentir, pensar e agir sobre esse tema, que tem sido considerado elemento indispensável para a concretização de políticas eficazes na garantia da educação de qualidade.

A pergunta orientadora deste projeto centra-se no que seria para os profissionais uma formação construída na profissão. Assim: Quais representações os profissionais da educação mantêm a respeito da formação continuada em serviço?

Assim, nosso pressuposto nesta pesquisa centra-se na ideia de que a forma como cada sistema de ensino articula a formação continuada, além de outros elementos do cotidiano dos sistemas de ensino, pode interferir na representação que seus profissionais elaboram sobre a capacitação profissional em serviço e conduzir suas ações e decisões em relação ao tema. Ao mesmo tempo, entendendo o movimento cíclico produzido entre representações e contexto, é possível afirmar a interdependência entre ambos.

Para tanto, nosso objetivo geral nesse trabalho é identificar que representações sobre formação contínua em serviço possuem professores e gestores dos três sistemas de ensino investigados.

Os objetivos específicos que orientaram esta pesquisa se deram no sentido de:

- Analisar as formas pelas quais os municípios pesquisados articulam as propostas de formação continuada às necessidades de formação dos professores das respectivas redes.

- Analisar representações dos professores dessas redes de ensino, a fim de apreender a imagem que fazem a respeito do processo de formação em serviço.

- Analisar representações dos gestores dos sistemas de ensino sobre formação contínua. 
Esta dissertação, exceto sua introdução e as considerações finais, foi organizada em duas partes. $\mathrm{Na}$ primeira parte encontram-se os três primeiros capítulos: 1) Formação Contínua: Responsabilidades e Desafios; 2) A teoria das representações de Henri Lefebvre: Uma possibilidade de conhecer as representações docentes sobre formação; 3) Metodologia, instrumentos de pesquisa.

O primeiro capítulo discute brevemente a problemática da formação contínua frente às exigências inerentes ao novo fazer docente, aos novos pressupostos que orientam a questão da formação de professores e às novas responsabilidades decorrentes da descentralização do ensino.

No segundo capítulo, expõe-se o marco teórico que sustenta esta pesquisa: a teoria das representações de Henri Lefebvre, cujos pressupostos fornecem a possibilidade de compreender as concepções docentes sobre formação e, em seguida, no terceiro capítulo, detalha-se a metodologia utilizada, descrevendo-se os instrumentos de pesquisa e a sua forma de análise.

$\mathrm{Na}$ parte dois - Os Sistemas de ensino: As relações entre contexto e representações - encontram-se os capítulos nos quais se analisam os dados da pesquisa. Dessa forma, nos capítulos quatro, cinco e seis expõem-se, respectivamente, os dados analisados considerando contexto e representações dos Sistemas A, B e C. Destacam-se, em cada um dos Sistemas, a legislação no que tange aos processos de formação contínua, a estrutura de formação contínua disponível e a organização. Expomos, também, a análise das manifestações de professores e gestores, analisando, em cada um, a maneira como os diversos elementos se articulam considerando o binômio contexto/representações.

O sétimo capítulo analisa os principais resultados da pesquisa mediante uma perspectiva comparativa, em que são confrontados os diversos aspectos considerados neste estudo.

Concluímos o texto através das considerações finais acerca dos resultados observados, propondo-se novas reflexões, reconhecendo a impossibilidade de esgotamento do assunto. 
PARTE I 


\section{A FORMAÇÃO CONTÍNUA DE PROFESSORES: Responsabilidades e}

Desafios

Segundo os novos pressupostos que orientam a forma de entender a tarefa de ensinar, não basta a mera transmissão de conhecimentos acadêmicos. Cabe ao professor e à escola, por exemplo, o combate ao analfabetismo cívico (IMBERNÓN, 1996), modificando a atividade do professor através do aparecimento de uma profissão cada vez mais complexa, que exige habilidades profissionais diferentes. Nesse sentido, a construção de um novo profissional requer uma formação inicial e permanente que atenda a tais exigências. O professor do século XXI precisa desenvolver capacidades de aprendizagem da relação, da convivência, da cultura, do contexto, das relações com todo o grupo que envolve a educação (IMBERNÓN, 2002).

Ao mesmo tempo em que presença de profissionais com novas habilidades se faz urgente, as escolas e os professores se veem em meio a um contexto em que os resultados por vezes negativos, presentes no cenário educacional atual são, na maioria das vezes, atribuídos aos agentes escolares, em especial ao professor que, desprestigiado socialmente, tende a ser o grande vilão. Oriundos das classes desfavorecidas, chegam à universidade com importantes defasagens educacionais, que muitas vezes não lhes permitem o rendimento e a aquisição dos saberes necessários ao ato de ensinar. Além disso, os cursos ligados à área do magistério, de modo geral, não têm fornecido subsídios teóricos e práticos para que possam intervir adequadamente. Decisivamente, a formação inicial tem deixado lacunas com relação ao cumprimento da tarefa de ensinar e propiciar às crianças a aquisição das habilidades exigidas pelas avaliações externas e o pleno desenvolvimento para o exercício da cidadania.

Vários são os problemas que reforçam a crise na educação brasileira, em especial na formação docente. Um deles é o grande número de cursos de licenciatura a distância, sobre os quais se exige cautela por conta dos questionamentos em relação à sua qualidade, especialmente quanto à tutoria, estrutura, acompanhamento e avaliação, já que cursos nessa modalidade demandam equipes docentes com boa formação, tecnologias sofisticadas e ágeis, materiais bem produzidos e testados, polos bem instalados, monitores e tutores bem formados, sistemas de controle bem delineados com pessoal adequado (GATTI et al., 2011, pág. 105).

Tanto os cursos presenciais como os ministrados a distância não apresentam uma base formativa comum. Seus currículos são fragmentados com um conjunto 
disciplinar bastante disperso. Embora se verifiquem, nos últimos anos, por parte do governo federal, iniciativas de enfrentamento do problema, os cursos voltados às licenciaturas apresentam-se, na maioria das vezes, com uma característica aligeirada, que pouco fortalece a profissionalização docente e as conexões entre teoria e prática. Segundo Gatti, Barreto e André, (2011, p. 114), "pouquíssimos cursos propõem disciplinas que permitam algum aprofundamento em relação a educação infantil, e, mesmo assim, o aspecto metodológico do trabalho com crianças é pouco referido.

Além das dificuldades apontadas em relação à formação inicial dos professores, são vários os pontos nevrálgicos observados nos programas de formação. Dentre eles, encontram-se poucas políticas que fortaleçam o corpo docente e as equipes como um todo, através de um trabalho colaborativo. Embora se reconheça a necessidade de trazer o debate acadêmico para dentro das escolas, não se observa a adequada exploração do papel das universidades e dos programas de formação em larga escala para que suas ações se articulem às necessidades das redes de ensino, já que a tendência de Estados e Municípios é a de abraçar propostas formatadas, que muitas vezes não oferecem respostas às problemáticas locais. O tempo e espaços destinados à formação e à socialização de experiências bem sucedidas são insuficientes, não havendo integração nas escolas, entre as escolas, e entre professores dos diferentes anos e segmentos. Ainda, não se observam ações no sentido de avaliar os resultados das capacitações oferecidas, através da observação da atuação dos professores, bem como da adoção de medidas quantitativas e qualitativas de avaliação e que serviriam também como ação formativa (DAVIS, NUNES e ALMEIDA, 2011).

Imbernón (2010) indica mudança na formação, apontando a existência de inúmeros programas com essa finalidade, bem como de incontáveis estudos sobre eles, mas destaca o baixo impacto que apresentam na qualidade de ensino e nas práticas dos docentes, o que faz com que o autor indique a necessidade de revisão crítica desses modelos de formação. A exemplo disso, apontamos o estudo de Bauer (2011), em que demonstra mudanças nos discursos dos professores participantes de um programa de formação oferecido em larga escala, mas não em suas práticas de sala de aula.

Fusari e Franco (2005) afirmam que pesquisas realizadas no Brasil e em outros países desde a década de 70 revelam um descompasso muito grande entre a mobilização para a "capacitação" e os poucos resultados e mudanças no processo de ensinoaprendizagem. Essas constatações contribuíram para o questionamento acerca da formação de professores como mudança de práticas e houve, então, um grande avanço 
na crítica às ações de formação baseadas numa concepção linear, prescritiva e extremamente pontual.

O descompasso entre formação, prática e sucesso na aprendizagem também encontra-se descrito nos relatórios do Programa de Promoção da Reforma Educativa na América Latina e Caribe - PREAL, do Programa Internacional de Avaliação de Alunos PISA e da Organização para Cooperação e Desenvolvimento Econômico - OCDE e é reforçado por Nóvoa (2011). Segundo ele, há um "consenso discursivo" diante das necessidades formativas, no entanto, as práticas dizem o contrário, "raramente temos conseguido fazer aquilo que dizemos que é preciso fazer" (p.4).

$\mathrm{Na}$ análise das políticas de formação em nível mundial, Gatti et al. (apud VESUB, 2005-2007) apontam problemas comuns em diferentes países. Segundo os autores, as ações são isoladas, pontuais e de curta duração, e reproduzem as mesmas relações de poder/saber próprias do vínculo escolar. Apontam ainda para a ausência de formação de grupos específicos e a não consideração do desenvolvimento profissional e de seus contextos, revelando ausência de monitoramento e avaliação eficientes, somando-se à descontinuidade de políticas e às ações adotadas na formação inicial.

As discussões atuais acerca do tema, especialmente as realizadas nos Estados Unidos, Canadá, Península Ibérica e alguns países da América Latina, vão ao encontro dos questionamentos básicos no campo e focam a necessidade de conexão entre as aprendizagens dos alunos e dos professores e o entendimento dos processos de mudança pessoal e profissional de docentes e demais profissionais que dão suporte à tarefa de ensinar, como supervisores, coordenadores e diretores.

\subsection{Os novos paradigmas na formação docente}

A realidade posta pelo atual cenário e as exigências por novas habilidades profissionais também impulsionaram mudanças na importância dada a este setor das políticas educacionais, fazendo surgir novos paradigmas na concepção da formação de professores, assim como diversos modelos aplicados.

Por longo tempo, os professores foram concebidos como um "conglomerado homogêneo" (GATTI, 1996) a quem era atribuída função unicamente instrumental, como reprodutores e meros executores de currículo, tendo com isso perdido a prática de se aventurar e ousar no exercício autônomo de produção de conhecimento pedagógico (IMBERNÓN, 1996). “Aos professores, permite-se apenas que ajustem os meios para 
se atingir objetivos definidos por outras pessoas. O ensino torna-se meramente uma atividade técnica". (ZEICHNER, 2008).

Inspirados nas ideias de John Dewey, que defendia a reflexão como o processo adequado de pensar a partir de situações problemáticas, vários autores, como Donald Schön, desenvolveram estudos sobre o profissional reflexivo que ajudaram a entender melhor como o profissional da escola compreende suas experiências e participa da aprendizagem profissional (SCHÖN, 1983). Conforme sinaliza Contreras (1999, p. 106),

A ideia de profissional reflexivo desenvolvida por Schön (1983; 1992) trata justamente de dar conta da forma pela qual os profissionais enfrentam aquelas situações que não se resolvem por meio de repertórios técnicos; aquelas atividades que, como ensino, se caracterizam por atuar em situações que são incertas, instáveis, singulares e nas quais há conflitos de valor. Para isso, Schön parte da forma com que habitualmente se realizam as atividades espontâneas da vida diária, distinguindo entre "conhecimento na ação" e "reflexão na ação".

Ultrapassando a concepção do professor apenas como reprodutor e veiculador de propostas prontas, Carr e Kemmis (1986 apud Diniz, 2002, p. 36) assinalam a ineficácia de uma formação com tais características e sugerem como as concepções baseadas no pensamento de Dewey podem trazer uma visão da educação como um processo complexo ou uma atividade modificada à luz das circunstâncias.

Profissionais sábios e experientes desenvolverão julgamentos altamente complexos e agirão com base nesses julgamentos para intervir na vida da sala de aula ou da escola e influenciar os eventos de uma ou de outra maneira. Mas os ventos da sala de aula terão sempre um caráter indeterminado e aberto. A ação dos profissionais em questão nunca controlará ou determinará completamente a manifestação da vida da sala ou da escola (CARR e KEMMIS, 1986 apud DINIZ, 2002, p.36).

Davis, Nunes e Almeida (2011) reforçam essa ideia e sinalizam para um debate intenso sobre as políticas de formação em serviço, como também para as mudanças em suas práticas em que a perspectiva em relação aos programas de formação continuada tem se modificado nas últimas décadas e os professores passam a ser vistos

[...] com suas identidades pessoais e profissionais, imersos numa vida grupal, na qual partilham de uma cultura, derivando dessas relações seus conhecimentos, valores e atitudes, com base nas representações constituídas nesse processo que é, ao mesmo tempo, 
social e intersubjetivo (GATTI, 2003, p. 196 apud DAVIS, NUNES e ALMEIDA, 2011).

No entanto, salienta a necessidade de conhecer tais experiências de formação, considerando suas restrições, limitações e equívocos quanto às possibilidades de ação e avanço.

Sob a perspectiva do tipo de orientação que conduz a formação contínua desenvolvida no Brasil, encontramos a predominância de dois principais modelos identificados no relatório de formação continuada realizado por Davis, Nunes e Almeida (2011). O primeiro deles foca o caráter individual, na figura do professor e na sua importância social, no qual ganha destaque a superação de déficits da formação inicial e os ciclos de vida profissional. O segundo modelo apóia-se no coletivo, na equipe pedagógica das escolas e se distingue em duas vertentes, ora centrado na figura do coordenador pedagógico, ora na equipe como um todo e na escola como lócus de formação. Esse segundo modelo, defendido principalmente por Fullan (1993), traz uma perspectiva cujas ações educativas mudam seu foco do individual ao coletivo, não se circunscrevendo ao individual e ao utilitário. Para o autor, é preciso mudar as concepções a respeito do aprimoramento profissional, dando-lhe, efetivamente, a característica de formação contínua. Assinala que é preciso que as escolas compartilhem de ideias básicas como: acreditar na possibilidade de superação daquilo que se faz, fazendo sempre mais e melhor; reconhecer a autocrítica como parte imprescindível no processo de melhoria profissional; cultivar atitudes de reconhecimento e disseminação de boas práticas pedagógicas; aceitar que, sem disposição para aprender, nada se consegue. Reforça, com isso, a ideia de formação contínua como uma tarefa complexa, que passa necessariamente pela coletividade dos indivíduos que compõem as equipes escolares e seus sistemas de ensino. Em suas palavras, "não se trata de transformar pessoas, mas sua cultura".

O conjunto das mudanças pelas quais a forma de entender a educação e as novas habilidades presentes na função docente passou a incluir também as mudanças na maneira de conceber a formação permanente desenvolvida pelos governos, que tem sido considerada condição sine qua non para o alcance de padrões de ensino mais elevados, uma vez que a partir das décadas de 1980 e 1990, com o debate da crise da escola e as transformações da sociedade globalizada, este aspecto das políticas de educação tem assumido papel central na discussão sobre o papel dos professores e sua profissionalidade. 
Diante das evidências de que a qualidade da educação oferecida em um país tem reflexos determinantes em seu desenvolvimento e na qualidade de vida existente em um determinado contexto (BALDOCK, MANNING E VICKERSTAFF, 2003), os professores e sua formação passam a ser o centro das preocupações e políticas educacionais, o que tem aumentado a sua responsabilidade, como também daqueles que atuam como formadores.

\subsection{Os sistemas municipais e a responsabilidade pela formação contínua de} professores

A complexidade imposta pelas exigências inerentes ao novo ato de educar, as deficiências observadas nos processos de formação inicial de professores e os novos paradigmas no campo da formação que sinalizam para que os resultados da formação docente ultrapassem os limites do discurso, constituindo-se, de fato, em saberes docentes que integrem o cotidiano das salas de aula e incidam sobre a aprendizagem dos alunos, impõe, em especial aos agentes formadores das secretarias municipais de educação, consideráveis desafios.

É preciso considerar que, para os sistemas municipais de ensino, a tradição no campo da formação de professores, dentre outros aspectos, como sua experiência acumulada no que se refere à orientação pedagógica, constitui-se atribuição relativamente recente. Nota-se que tais responsabilidades nem sempre foram delegadas aos municípios, uma vez que, somente após a Constituição Federal de 1988, a Lei de Diretrizes e Bases da Educação 1996 e, sobretudo, após a EC 14/96, os municípios assumem novas atribuições e responsabilidades educacionais.

É na perspectiva dos desafios apontados nas novas configurações políticas, legais e administrativas fomentadas pela descentralização das decisões sobre o ensino, aliadas às responsabilidades sinalizadas pela atual LDB, que está inserida a demanda de promover de forma autônoma a formação de professores com vistas à garantia de uma educação de qualidade para todos os alunos. Tal incumbência, prevista na Lei de Diretrizes e Bases, em seu artigo 62,§ $1^{\circ}$ esclarece que "A União, o Distrito Federal, os Estados e os Municípios, em regime de colaboração, deverão promover a formação inicial, a continuada e a capacitação dos profissionais de magistério". Ao mesmo tempo, garante através de seu artigo 67, que os planos de carreira devem assegurar "período reservado a estudos, planejamento e avaliação, incluído na carga horária de trabalho". 
De maneira decisiva, a Constituição de 1988 inaugurou para os municípios brasileiros um período em que suas responsabilidades educacionais passam a ser maiores. Ainda segundo a Lei de Diretrizes e Bases da Educação de 1996,

Os Municípios incumbir-se-ão de:

I - organizar, manter e desenvolver os órgãos e instituições oficiais dos seus sistemas de ensino, integrando-os às políticas e planos educacionais da União e dos Estados;

II - exercer ação redistributiva em relação às suas escolas;

III - baixar normas complementares para o seu sistema de ensino;

IV - autorizar, credenciar e supervisionar os estabelecimentos do seu sistema de ensino;

V - oferecer a educação infantil em creches e pré-escolas, e, com prioridade, o ensino fundamental, permitida a atuação em outros níveis de ensino somente quando estiverem atendidas plenamente as necessidades de sua área de competência e com recursos acima dos percentuais mínimos vinculados pela Constituição Federal à manutenção e desenvolvimento do ensino.

VI - assumir o transporte escolar dos alunos da rede municipal.

As imposições da legislação educacional, que indicaram fortemente a descentralização do ensino, deflagram os processos de municipalização do ensino fundamental. No estado de São Paulo esse processo teve início, efetivamente, no ano de 1996, quando 46 municípios paulistas tiveram, parcialmente, seu ensino municipalizado.

O processo, que se intensificou em 1998 através do decreto $\mathrm{n}^{\circ}$ 43072, representou um instrumento para celebrar o convênio de parceria educacional entre estados e municípios. Além disso, foram publicados diversos decretos e resoluções ${ }^{3}$

\footnotetext{
${ }^{3}$ O Decreto 40.673/96, posteriormente alterado pelo Decreto 40.889/96, instituiu o programa Ação de Parceria Educacional Estado-Município para atendimento ao ensino fundamental, consolidando o processo de municipalização, iniciado em 1989 com o Decreto 30.375/89. O instrumento administrativo criado para viabilizar o programa foi um Termo de Convênio, do qual faziam parte um Plano de Trabalho com objetivos e metas, um Plano de Aplicação de Recursos e um Cronograma de Desembolso Financeiro. $\mathrm{Na}$ assinatura dos dois primeiros eventos de municipalização, apenas 46 municípios apresentaram todas condições legais e financeiras para aderir a parceria. Os professores, diretores e coordenadores pedagógicos foram cedidos por cinco anos de vigência dos convênios, embora sua situação funcional não se alterasse: continuaram a ser funcionários do estado, sem perdas e vantagens trabalhistas, e o estado permanecia responsável por seus salários e aposentadorias. Mensalmente os municípios deveriam reembolsar ao estado apenas o montante da folha de pagamento desses profissionais (MARTINS, 2003, p.8).
} 
para viabilizar a municipalização, garantindo o amparo legal e financeiro. Segundo a $\mathrm{SEE} / \mathrm{SP}$, o processo de municipalização deveria ser incorporado pelos municípios para assegurar os preceitos definidos na Constituição Federal de 1988 que, em seu artigo 211, parágrafo $2^{\circ}$, define a obrigatoriedade dos Municípios atuarem prioritariamente no Ensino Fundamental e na Educação Infantil.

\section{GRÁFICO 1 - DISTRIBUIÇÃO DAS MATRÍCULAS DE ENSINO FUNDAMENTAL ( $1^{\mathrm{a}}$ a $4^{\mathrm{a}}$ série) DEPENDÊNCIA ADMINISTRATIVA DO ESTADO DE SÃO PAULO, 1996 -2001}

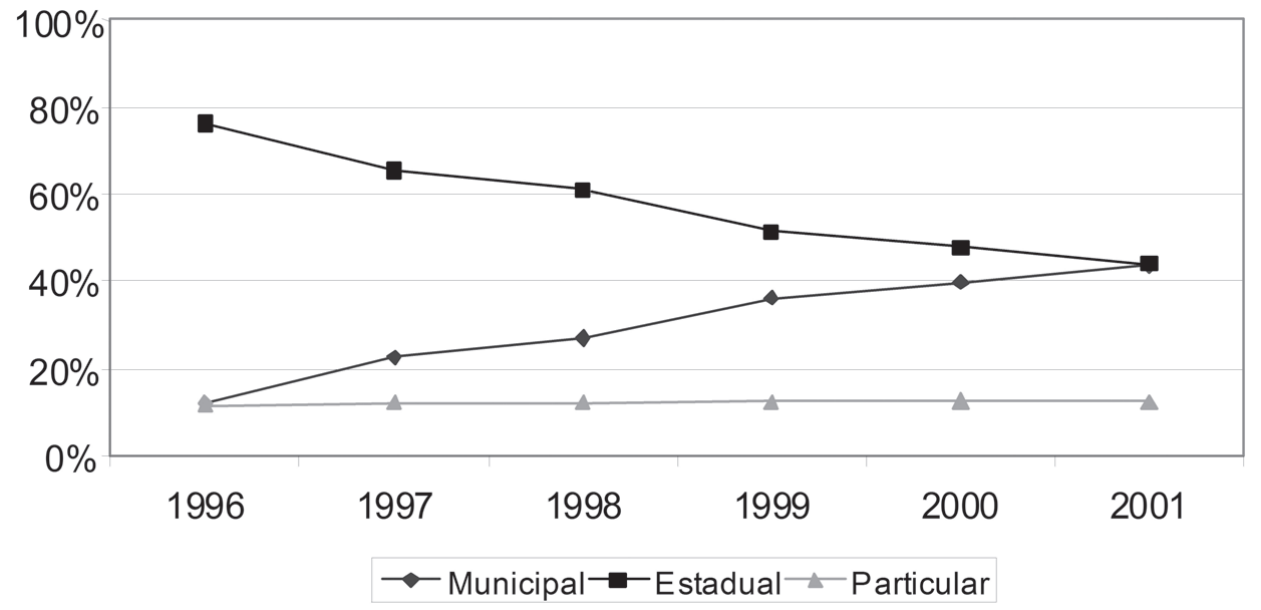

Fonte: Centro de Informações Educacionais - CIE/Secretaria de Estado da Educação do Estado de São Paulo - SEESP - .

Como se pode observar no gráfico acima, a Secretaria Estadual da Educação, responsável por $79 \%$ das matrículas do ensino fundamental em 1995, teve um decréscimo no atendimento para essa etapa de ensino, caindo de $77 \%$ para $44 \%$ no período de 1996 a 2001, ao mesmo tempo em que os municípios saltaram de 12\% para $44 \%$ sua participação no conjunto da oferta. 


\section{GRÁFICO 2 - DISTRIBUIÇÃO DAS MATRÍCULAS DE \\ ENSINO FUNDAMENTAL (ANOS INICIAIS) \\ DEPENDÊNCIA ADMINISTRATIVA DO \\ ESTADO DE SÃO PAULO, 2005 - 2014}

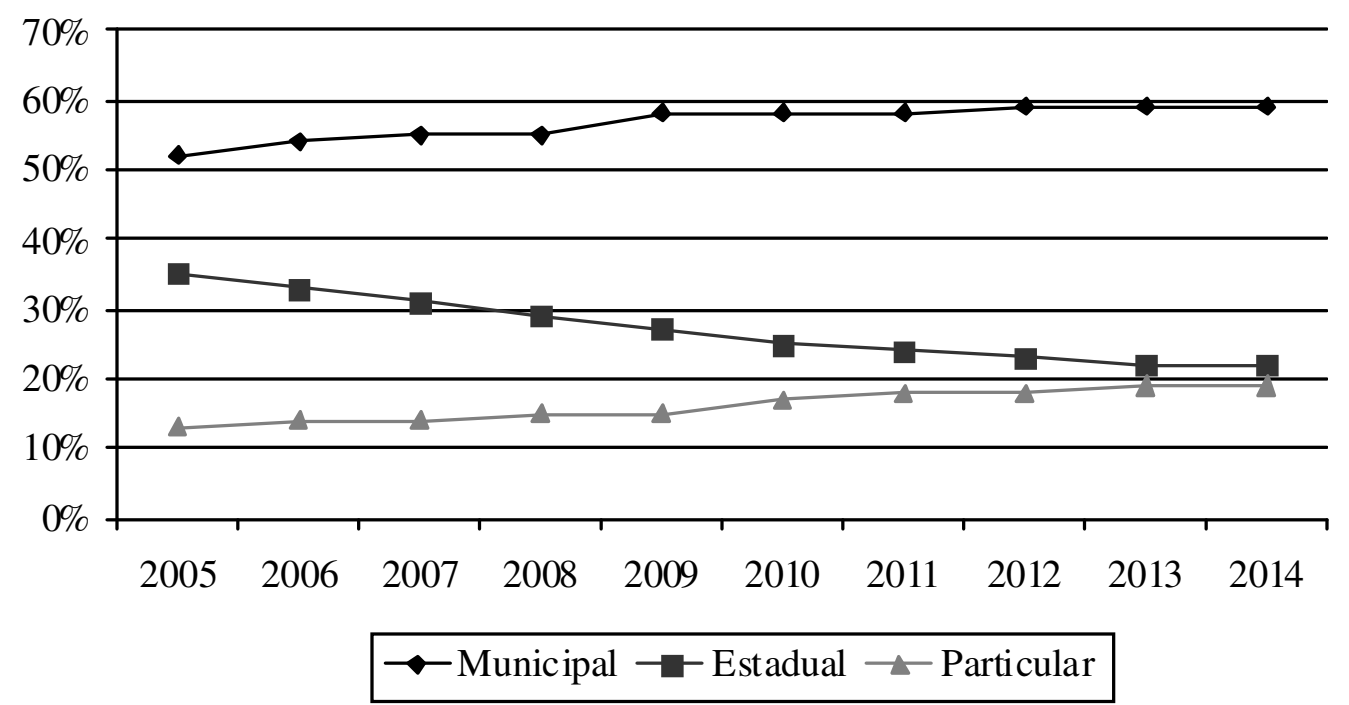

Fonte: Seade

O decréscimo do atendimento na rede estadual se mantém ao longo dos anos, decaindo a $22 \%$ do total de matrículas nos anos iniciais do ensino fundamental, em 2014. As redes municipais se consolidam como detentoras dos maiores percentuais, alcançando, em 2014, 59\% do total de matrículas no segmento. É interessante notar, ainda que este não seja o foco deste estudo, que a rede particular tem aumentado sensivelmente seu número de matrículas nos últimos anos.

As novas competências originadas a partir do processo de municipalização provocaram mudanças nas configurações das secretarias de educação dos municípios. Martins (2003) aponta a municipalização do ensino como um processo cuja arquitetura gerou um mosaico fragmentado, que desconsiderou as peculiaridades locais em sua implementação.

(...) A necessidade de forjar novas formas de desempenho das políticas educacionais exige que as instituições envolvidas em sua implementação adquiram um novo corpo de informações e de conhecimentos burocrático-administrativos para assumir as novas funções, o que, sem dúvida, gera um período de tensão política e de vácuo no conjunto normativo-legal, pois sua racionalidade não responde mais às necessidades do cotidiano. Isto é, entre o que este conjunto propugna para que a gestão da política educacional funcione em outro paradigma, e sua efetiva operacionalização, configura-se um período de instabilidade institucional que imprime rumos inesperados às suas diretrizes, na tentativa de romper a cultura fortemente arraigada em seus órgãos gestores e nas próprias unidades escolares. É nesse vácuo que os professores, diretores e coordenadores pedagógicos têm sido chamados a desempenhar suas funções, enfrentando as inovações propostas pelas Secretarias Municipais de Educação, estas próprias protagonistas estreantes em 
seus novos papéis institucionais, pois acabaram de assumi-los. Temos, portanto, uma dupla aprendizagem: da própria esfera executiva municipal que está aprendendo a desempenhar suas novas funções e dos atores escolares, demandados a serem criativos, colaboradores e aceitarem as mudanças propostas e a compreenderem a situação de indefinição profissional a que estão submetidos (MARTINS, 2003, p. 12).

A política de descentralização tem, segundo a mesma autora, fortes argumentos voltados para a defesa da localidade como espaço para o exercício da democracia, além da necessidade de novos modelos de gestão de ensino, uma vez que os grandes sistemas vinham mostrando-se incapazes de oferecer educação de qualidade e responder com rapidez aos diversos problemas, nas mais diversas cidades do estado. Assim, a diversidade de problemas encontrados teria maiores possibilidades de resolução, uma vez que a proximidade com o poder executivo permitiria maior participação dos profissionais da educação, dando a eles maiores chances de reivindicação (MARTINS, 2003).

No entanto, o "jeito de fazer política” (MARTINS, 2003) presente nas relações institucionais poderia representar entraves, como a manipulação das informações em favor de interesses locais e de grupos, desprezo pelos novos critérios apontados para as novas formas de administrar, negociação de influências e níveis de participação nas decisões da esfera executiva em favor de interesses de grupos, enfim, questões que influenciariam substancialmente o modelo de gerenciamento da política educacional.

Com a descentralização do ensino, os municípios passam, assim como os sistemas estaduais de ensino, a responder pelos índices que avaliam o rendimento dos alunos. Nesse sentido, principalmente o IDEB - Índice de Desenvolvimento da Educação Básica, tem atualmente representado para a sociedade um instrumento de medida da qualidade do ensino oferecido e, dessa forma, influenciado fortemente a condução das políticas de formação continuada. O IDEB, criado em 2007 pelo INEP, é resultado da combinação de dois fatores: a) indicadores de fluxo (aprovação, reprovação e evasão) e b) indicadores de desempenho medidos pelos exames realizados a cada dois anos nas séries finais do ensino fundamental ( $5^{\circ}$ e $9^{\circ}$ ano $)$, a Prova Brasil.

A implantação do IDEB traz explicitada a intenção de que as escolas se configurem em instâncias eficazes de construção de uma aprendizagem sólida, através da elevação gradativa de seus índices individuais, elevando, assim, os índices dos municípios, dos estados e do Brasil que têm seu índice projetado para 6,0 em 2021. 
Paz (2010) aponta a elevação do IDEB como um das principais objetivos do PDE - Plano de Desenvolvimento da Educação. O plano que, segundo o autor, não procura esconder tais interesses, recorre a políticas de responsabilização (accountability) e responsabilização social.

Se a educação é definida, constitucionalmente, como direito de todos e dever do Estado e da família, exige-se considerar necessariamente a responsabilização, sobretudo da classe política, e a mobilização da sociedade como dimensões indispensáveis de um plano de desenvolvimento da educação. Com efeito, a sociedade somente se mobilizará em defesa da educação se a incorporar como valor social, o que exige transparência no tratamento das questões educacionais e no debate em torno das políticas de desenvolvimento da educação. Desse modo, a sociedade poderá acompanhar sua execução, propor ajustes e fiscalizar o cumprimento dos deveres do Estado (BRASIL, 2007, p. 11).

Mesmo reconhecendo os avanços em relação às ações propostas pelo $\mathrm{PDE}$, o autor não deixa de ressaltar os perigos em reduzir as metas do plano aos resultados das avaliações externas que gerarão o IDEB.

Afonso (1999), ao apresentar as tensões do "paradoxo do Estado neoliberal", que tem se caracterizado por suas decisões ao mesmo tempo altamente centralizadoras e intervencionistas versus aquelas de caráter não-intervencionistas e descentralizadoras, descreve um cenário em que elementos do mercado e outras lógicas do setor privado fomentam determinados tipos de avaliação, especialmente a designada pelo autor como avaliação "estandardizada criterial com publicitação de resultados".

Como mostra Mary Henkel em Government, evaluation and change estudo que cobre um período decisivo de transformações nas políticas públicas inglesas, entre 1983 e 1989, "o governo identificou a avaliação como uma componente significativa na sua estratégia de conseguir alguns objetivos decisivos: controlar as despesas públicas, mudar a cultura do setor público e alterar as fronteiras e a definição das esferas de atividade pública e privada"(cf. Henkel 1991ª, p.9). Desse modo, a avaliação reaparece claramente relacionada com funções gestionárias tendendo a ser, como refere E. House(1993, p. $\mathrm{x}$ ), uma "avaliação centrada na eficiência e na produtividade sob o controle direto do Estado" (AFONSO, 1999, p. 146).

A busca por uma educação de melhor qualidade baseada nas avaliações externas tem conduzido à lógica de gerenciamento da educação. Souza (2011) aponta como principais elementos dessa lógica a ênfase nos produtos ou resultados, a atribuição de mérito a alunos, instituições ou redes de ensino, dados de desempenho escalonados, 
resultando em classificação, dados predominantemente quantitativos, destaque à avaliação externa, não articulada à autoavaliação. Segundo a autora, tais procedimentos geram algo que considera incompatível com os princípios da educação: uma competição na qual o maior perdedor é quem mais pode estar necessitando do apoio das esferas governamentais.

O IDEB, dessa forma, constitui uma importante marca do atual cenário educacional dos sistemas municipais de ensino e aparece como um forte condutor de diversas ações ligadas às políticas educacionais e, dentre elas, a formação contínua de professores. Nesse sentido, nota-se que, a exemplo do IDEB, outros fatores interferem diretamente na formulação e condução de tais políticas, como é o caso das novas configurações de carreira, em decorrência da autonomia municipal instituída a partir da descentralização do ensino.

Paz (2014), ao analisar a configuração dos estatutos e planos de carreira do magistério público em quinze municípios sedes das regiões do Estado de São Paulo, conclui que os processos de descentralização possibilitaram, de fato, formulações de políticas de carreira conforme os contextos locais e exercício de diferentes poderes. No entanto, destaca que, das legislações municipais analisadas, "27\% sequer tratam do afastamento ou licença remunerada para frequentar cursos de aperfeiçoamento, especialização ou pós-graduação, havendo pouco avanço no que tange à regulamentação de critérios objetivos para sua concessão" (PAZ, 2014).

Ainda no que tange à ligação entre formação contínua e carreira docente, aponta que em mais da metade dos estatutos e planos de carreira, a progressão funcional não está atrelada à avaliação de desempenho, mas à apresentação de cursos, atualização, aperfeiçoamento, licenciatura e pós-graduação.

Ramos (2013), ao estudar as ações de formação de dois municípios paulistas Monte Mor e Sumaré - observou, dentre outros aspectos apontados pela autora, nos dois municípios, a existência de impactos na carreira gerados pela participação na formação contínua, o que, em sua análise, estaria impulsionando uma "corrida por certificação", levando os professores dessas redes a recorrer a instituições com pouca ou nenhuma tradição na busca de realização de cursos de pós-graduação, apenas pelos benefícios que seriam obtidos na evolução salarial.

As configurações do atual cenário educacional, incluindo os aspectos já descritos, têm impulsionado os sistemas municipais de ensino a investir na formação e desenvolvimento de professores e as políticas educacionais implantadas desde meados 
da década de 1990, no Brasil, trouxeram grandes possibilidades de investimento nessa área, devido à instituição do FUNDEF - Fundo de Manutenção e Desenvolvimento do Ensino Fundamental e Valorização do Magistério, criado por iniciativa do governo federal através da Emenda Constitucional n. 14, de 12 de dezembro de 1996.

Inseridos dentro dessa perspectiva de autonomia educacional local, os sistemas de ensino municipais têm procurado realizar uma capacitação em serviço com o objetivo de que as habilidades de seus profissionais evoluam. Através de contratação de profissionais ou empresas, de forma direta ou indireta, a maioria tem procurado preparar mais e melhor seus profissionais.

Com a criação do FUNDEB - Fundo de Manutenção e Desenvolvimento da Educação Básica, através da Emenda Constitucional n. 53, de 6 de dezembro de 2006, a regulamentação dos percentuais de investimento do fundo foi mantida, tendo sido autorizadas ações de formação a partir da utilização da parcela de $40 \%$ do fundo, sendo incluídos, a partir de então, os professores da creche ao ensino médio.

As Orientações Gerais para a Rede Nacional de Formação Continuada (2005) esclarecem

A Lei $n^{\circ} 9424$ que instituiu o FUNDEB estabelece que 60\% dos recursos do Fundo sejam destinados à remuneração do magistério, sendo que a parcela restante (de até $40 \%$ ) deve ser aplicada em ações variadas, de manutenção e desenvolvimento do ensino fundamental público, dentre as quais a formação (inicial e continuada) dos professores e a capacitação de pessoal técnico-administrativo.

De igual modo, Resolução $\mathrm{n}^{\circ}$ 03/97, do Conselho Nacional de Educação, definiu, no artigo $5^{\circ}$, que os sistemas de ensino "envidarão esforços para implementar programas de desenvolvimento profissional dos docentes em exercício, incluída formação em nível superior em instituições credenciadas, bem como, em programas de aperfeiçoamento em serviço". Desse modo, os planos de carreira devem incentivar a progressão, por meio de qualificação inicial e continuada dos trabalhadores da educação. Por suas vez, o Plano Nacional de Educação - PNE - (Lei n. 10.172/2001), ao estabelecer os objetivos e metas para a formação inicial e continuada dos professores e demais servidores da educação, enfatiza que se faz necessário criar programas articulados entre as instituições públicas de ensino superior e as secretarias de educação, de modo a elevar o padrão mínimo de qualidade de ensino (BRASIL, 2005, p.16).

Dessa forma, Estados e Municípios passaram a ter mais possibilidades de investir e organizar sua formação permanente, bem como de participar dos programas organizados pelo governo federal, integrando, como exemplo, ações como as previstas na Rede Nacional de Formação Continuada, através dos programas Pró-Letramento, Gestar II e Especialização em Educação Infantil, e mais recentemente, implementando 
as ações do PNAIC - Pacto Nacional de Alfabetização na Idade Certa. A organização/gestão da educação em nível municipal adquire amplitude e importância no tempo presente, sendo fundamental para a construção de uma educação pública que seja realmente democrática e de qualidade para todos (BORDGNON; GRACINDO, 2004; GRACINDO, 2001).

Dentre as grandes preocupações e dificuldades observadas quando se analisam as propostas de formação de professores em Estados e Municípios encontra-se a falta de delineamento de suas principais linhas, incluindo a forma de articular as escolas e o sistema municipal, bem como aquelas organizadas por agências externas, como é o caso das parcerias com universidades e programas de larga escala como os desenvolvidos pelo governo federal.

O estudo de Davis, Nunes e Almeida (2011) constatou que as secretarias municipais de educação

ainda não tinham elaborado uma política de Formação Continuada com contornos próprios. Nelas, dois procedimentos foram observados: a) relegar a Formação Continuada dos docentes às iniciativas das próprias escolas, sem lhes fornecer amparo efetivo quanto a como proceder, algo que equivale a abandonar a função de estados e municípios de aprimorar suas respectivas redes de ensino; e, b) contratar firmas especializadas em formação continuada, que oferecem pacotes formativos prontos para o conjunto dos professores, independentemente de seus problemas e necessidades, ignorando a variedade de suas demandas e, inclusive, as de aprendizagem dos alunos (DAVIS, NUNES E ALMEIDA, 2011).

Segundo o mesmo estudo, o que ocorre atualmente, sobretudo nas secretarias municipais de educação, é a ausência de um conhecimento sólido de suas redes de ensino, que lhes permita diagnosticar carências e possíveis encaminhamentos para.

As políticas de formação continuada desenvolvidas nos municípios têm sido fortemente determinadas por um conjunto de elementos que compõe o atual cenário da educação brasileira, no qual se destacam os avanços no campo do conhecimento, as avaliações censitárias em nível nacional e estadual, as reformas curriculares ocorridas nos anos de 1990, a descentralização do ensino, etc. Essas medidas, importantes por buscarem a superação dos problemas de acesso e permanência, acabaram por descortinar as deficiências nos processos de formação inicial e continuada, uma vez que se reconhece que a qualidade da escolarização oferecida às crianças e jovens entrelaça- 
se ao desenvolvimento profissional dos professores, em articulação com o trabalho docente.

Diante de tais responsabilidades, impõem-se para os sistemas municipais de ensino os desafios de articular seus projetos político-pedagógicos a fim de que contemplem maior coerência entre suas metas, ações e resultados. Salienta-se necessidade de que na formulação de suas políticas docentes estejam articulados os diversos aspectos que envolvem carreira e formação contínua, de modo que as progressões funcionais não estejam vinculadas à mera apresentação de títulos e certificados voltados à progressão acadêmica e não acadêmica. 


\section{A TEORIA DAS REPRESENTAÇÕES DE HENRI LEFEBVRE: UMA POSSIBILIDADE DE COMPREENDER AS CONCEPÇÕES DOCENTES SOBRE FORMAÇÃO}

A teoria das Representações de Henry Lefebvre significou neste estudo a lente pela qual observamos a realidade pesquisada - os sujeitos, suas falas e atitudes e o contexto cultural/educacional nos quais se inserem. Foi através desse referencial teórico que nos orientamos ao considerar as representações como um meio de compreender que sentidos os sujeitos envolvidos nesse estudo, sejam eles professores ou gestores escolares, atribuem aos processos de formação contínua, seja participando, planejando ou executando as ações condizentes a cada âmbito de atuação.

Reconhecemos que a teoria das Representações trouxe novas possibilidades de entender os indivíduos não só como processadores de informações, mas como sujeitos que produzem e comunicam ativamente suas representações. Nessa perspectiva, "A questão da representação passa a ser questão básica. E o que, de um modo geral, diferencia a pesquisa, nesse campo, daquela realizada no interior das ciências empíricas é o fato de o sujeito fazer parte do que se quer conhecer" (PENIN, 2013, p. 141), deixando evidente a impossibilidade de separação entre sujeito, objeto e sociedade.

Não podemos entender o estudo das representações como posicionamentos ou produção de imagens que servem à interpretação, mas sim como uma teorização dotada de linguagem e estrutura própria, que influencia valores e conceitos, interpretando, formando o real e produzindo comportamentos e relações com o meio ambiente. Sua função é contribuir para a formação de condutas e orientação nas comunicações sociais.

Henri Lefebvre (1983) descreve as representações como "(...) contemporâneas da constituição do sujeito, tanto da história de cada indivíduo como na gênese do indivíduo na escala social"(LEFEBVRE, 1983, apud PENIN e ROBERTI, 2013, p. 152).

Lefebvre (1983) desenvolveu os conceitos de "vida cotidiana" e "obra", dentre outros, que nos permitem uma análise sobre o contexto escolar. A vida cotidiana, repleta de fatos comuns e repetitivos, configura um nível da totalidade composta pela

diversidade de ações e sentimentos humanos. É no cotidiano, constituído como um nível de realidade social, o local de construção e transformação da sociedade. Desvelar esse nível significa compreender as representações. Para ele, há uma ruptura entre sujeito e 
objeto do conhecimento e as representações ocupam um espaço "entre" o indivíduo e a sociedade, cujo conceito é formulado a partir de condições históricas.

Conforme sinaliza Penin (1989, p.39),

(...) é no âmbito da análise do cotidiano que podemos melhor entender as ações dos sujeitos que movimentam a escola e com isso alcançar a natureza dos processos constitutivos da realidade escolar, tendo em vista a sua transformação.

As representações, segundo Lefebvre (1983), são formadas pelo "vivido" e pelo "concebido". O primeiro forma-se a partir das experiências da vida social e prática nos planos individuais e coletivos dos indivíduos, enquanto o último é constituído pelo discurso teórico sobre o saber criado e divulgado, num movimento incessante, dialético, que ocupa lugar entre os dois. Caracterizam-se por sua natureza ao mesmo tempo social, psíquica e política e formam-se a partir da maneira pela qual os grupos são e se comportam, como se veem, pensam sua maneira de agir, como sofrem e sonham o futuro. As

“(...) representaciones no son simples hechos, ni resultados comprensibles por su causa ni simples efectos. Son hechos de palavra ( o si prefere de discurso ) y de practica social" (LEFEBVRE, 1983, p. 94 - 95).

No mesmo sentido, SACRISTAN (1998) assinala:

A educação é um campo de pensamento e prática no qual projetamos ideais diversos, utopias individuais e coletivas, ideologias globais ou valores concretos que pretendemos que se desenvolvam e que outros compartilhem, por meio de propostas, ou por meio de imposições e também por manipulações ocultas. Tanta projeção e carga ideológica gera por si mesma um discurso, uma linguagem que costuma, com demasiada freqüência, desligar-se da realidade e ganhar autonomia própria.. Nessa medida nem sempre dá conta da realidade, e até pode ocultá-la e manipulá-la. O discurso muda e se remodela, porque, como afirma Cherryholmes (1988, p.3), tem relação com tempo e lugar, mas essas mudanças não deveriam confundir-se com outros correlativos na prática à qual se referem. Não se pode dizer que $o$ que se diz e o que acontece sejam realidades totalmente independentes, mas sim que gozam de certa autonomia. Daí ser evidente que, para conhecer a realidade, é preciso ir além do discurso que se elabora sobre a mesma. (SACRISTAN, 1998, p. 135)

Conhecer a realidade, dessa forma, significa reconhecer o poder das representações nesse espaço entre o "vivido" e o "concebido", onde se pode, por conta 
desse poder, substituir a realidade vivida pela percebida pelos sujeitos. Sendo resultado do ser individual e social é inerente ao viver e sua compreensão.

Sabemos que a cultura escolar constitui-se de saberes sistematizados relativos à pedagogia e de saberes provenientes da lógica institucional, composta por saberes ou práticas discursivas - interpretações, reinterpretações ou até distorções, presentes no cotidiano escolar (PENIN, 1995). Neste sentido, a formação em serviço ou a reflexão crítica sobre a prática representa um dos temas que permeiam essas práticas discursivas.

Dessa forma, não são apenas os conceitos, as teorias, as ideologias, formadoras do "concebido", os únicos elementos a serem considerados na análise. O senso comum, o do conhecimento adquirido no cotidiano de um mundo habitado por representações, onde as realidades individuais se articulam com o saber, os sonhos e as lembranças e as ficções, constitui a chave da compreensão do homem na sociedade.

De acordo com Lefebvre, "las representaciones no son falsas ni verdaderas, sino La vez falsas o verdaderas: verdaderas como respuestas a problemas "reales"”. (LEFEBVRE, 1983, p.62). Assim, não se deve compreender as representações com a pretensão de rechaçá-las, já que os processos pelos quais se formam, ganham força, circulam e deslocam o representado, sobreposto por seu representante por meio da representação. Segundo Lefebvre (1983), aquilo que se representa está presente e ausente na representação que medeia essas duas ocorrências não excludentes, faces de uma mesma condição de existência mútua.

Conforme pondera Lufti (1996, p.96),

(...) não é possível viver e compreender uma situação sem representála. A filosofia, tradicionalmente, quer eliminar as representações. Sem elas, entretanto, só restam a morte e o nada. A teoria deve expor o poder da representação no mundo contemporâneo, deslindar os mecanismos de sua produção e permanência, e ao fazê-lo, anunciar um pensamento novo e ativo já em marcha.

Nessa perspectiva, é também necessário compreender as representações para além da visão simplificadora do certo/errado, existe/não existe, falso/verdadeiro, desvelando sua ação motivadora e inibidora, clarificadora e mistificadora nas condutas que envolvem o fazer escolar.

Outro conceito de grande importância a ser compreendido é o conceito de obra, cujo sentido, segundo Lefebvre (1983), esclarece as representações e é por elas 
esclarecido, num movimento que remete à prática, à criação. Rica, inesgotável para a análise, indecifrável. Única e ao mesmo tempo feita de uma multiplicidade, mantém sua originalidade.

Lefebvre (1983) afirma que as representações fazem a mediação para o verdadeiro conhecimento. A questão, segundo ele, é que tanto representações como conhecimento podem se objetivar, alertando sobre a importância de se estudar cada uma delas. Das representações podem se originar mimetismos e simulacros, que apresentam independência entre o saber crítico e a atitude crítica. Mesmo sabendo que esta última pode propor mais mudanças no contexto, é importante estudar a natureza das objetivações, já que, como produtos, se assemelham às obras.

Nas obras não há essa independência, uma vez que seu caráter orgânico é de totalidade. A tarefa da pesquisa é distinguir as verdadeiras obras dos simulacros e mimetismos, reconhecendo nos diferentes contextos os processos de superação das representações, que se constituem como um espaço de busca, de procura, de "ausência", como denomina Lefebvre (1983) .

O pensamento de Henri Lefebvre sobre a importância do conhecimento cotidiano confirma este propósito de investigação, já que a validade das ideias que são apresentadas pode ser verificada através da "fala" de professores e gestores nos contextos investigados. Podemos afirmar que, por esse viés teórico, é possível verificar o posicionamento desses profissionais, formado pela vivência singular de cada sujeito e pela vivência coletiva e social dos sujeitos envolvidos em seus contextos específicos, frente aos novos arranjos da formação continuada em serviço com relação às concepções básicas desses docentes.

Reconhecemos que os professores e gestores demonstram suas representações não só através de suas manifestações, mas também ao adotar posturas, em nosso caso específico, as posturas e atitudes identificadas a partir de um nível de realidade descrito através da fala. Sendo assim, entendemos que, para identificar as representações, não basta ouvir os professores, mas procurar apreender como agem no cotidiano e em sala de aula, ainda que através do nível de realidade manifesto nos discursos. Além disso, ao analisar as circunstâncias de comunicação e os registros escritos através dos quais os docentes das redes pesquisadas manifestam-se avaliando, sugerindo ou mesmo planejando, reúne-se um conjunto de dados empíricos que tornarão possível esta análise.

Assumimos a teoria de Lefebvre como um referencial capaz de oferecer a possibilidade de análises das representações que, na prática, pretendem apreender sua 
estrutura discursiva e simbólica, buscando as unidades nucleares do conteúdo, seus significados e relações com o "dito" pelos indivíduos. Em cada um dos contextos analisados, perceberemos como cada sujeito se apropria do que foi selecionado a respeito de sua realidade, considerando como ele combina, estrutura e reestrutura esses elementos.

A contribuição desta pesquisa está em desvelar em que medida as ações articuladas pelos sistemas de ensino pesquisados, no que se refere ao alcance de uma prática mais reflexiva e inovadora, superam as representações, suplantam o real, movimentam-no, propondo uma realidade diferente. Em outras palavras, o quanto esses projetos são reveladores de verdadeiras obras, e o quanto representam apenas produtos.

Para Lefebvre, uma obra se caracteriza pelo fato de não refletir o real, mas por suplantá-lo, movimentá-lo, por propor uma realidade diferente, por conter sempre uma utopia. Ser um lugar de um não-lugar. Ao mesmo tempo em que mostra as contradições, resolve-as. Para ele

El producto se reproduce por repetición, equivalencia, identificación.
Reproduce su condición. La actividad productora tiende a volverse
autónoma. Por el contrario, la actividad poiética no puede dejar de
acentuar su carácter apropiador. Se apropia las condiciones exteriores
transformándolas, o sea todos los fragmentos de la unidad
fragmentada. Es económica, social, política, técnica, implica un saber
y un mercado, etcétera. Lejos de volverse autónoma, establece un
nexo de comunicación, una mediación universal (LEFEBVRE, 1983).

Investigar a realidade educacional desses três municípios, procurando captar momentos de ausência, de busca, de conhecimentos e desconhecimentos (LEFEBVRE, 1983) é uma forma de entender a origem das representações para superá-la. Um percurso de confrontação entre representações, conhecimento sistematizado, saber cotidiano e formas pessoais de entendimento, "pode operar o movimento lógicodialético, transformador de representações em conhecimentos" ( PENIN, 1995, p. 12).

Nesse sentido, a perspectiva de análise sob o viés da teoria de Lefebvre pode contribuir na análise dos fenômenos que conferem à prática cotidiana um caráter de reprodução ou de transformação. Analisando-se criticamente este nível de realidade, é possível enfatizar o poder das representações, neste caso, dos professores e gestores das referidas redes de ensino acerca do processo de formação continuada. 
Não pretendemos, no entanto, apresentar afirmações conclusivas em torno das representações, pois, segundo Lefebvre (1983), o estudo do cotidiano de uma determinada realidade reflete apenas aquela realidade específica, naquele momento. Nessa lógica dialética entre os conceitos, perceberemos como, de alguma forma, a ausência se torna presença através das ações evidenciadas, podendo representar, neste contexto, a obra.

Dessa forma, seja a conclusão dessa pesquisa o desvelamento de simulacros, criações miméticas ou, na melhor das hipóteses, de verdadeiros momentos de criação, entendemos que reconhecer a realidade posta pode auxiliar na superação de práticas de formação ineficazes e contribuir para a reflexão no processo de planejamento das formações docentes em serviço, realizado por gestores municipais. Como afirma Lefebvre (1983, p. 243-244), "é na vida cotidiana e a partir dela que se cumprem as verdadeiras criações, aquelas que produzem os homens no curso de sua humanização: as obras". 


\section{METODOLOGIA: INSTRUMENTOS DE PESQUISA, COLETA E ANÁLISE DOS DADOS}

A metodologia utilizada neste estudo se apoia na perspectiva da antropologia dialética de Henri Lefebvre, reconhecendo no método uma possibilidade de compreender e explicar os problemas e as contradições que envolvem a produção de explicações sobre os fenômenos sociais.

O encaminhamento da pesquisa nessa direção leva-nos à condução do que Lefebvre (1985) nos aponta como algumas das regras práticas do método dialético. “Tudo está ligado a tudo" e que uma interação insignificante, negligenciável por que essencial em determinado momento, pode tornar-se essencial num outro momento ou sob um ou outro aspecto (LEVEBVRE, 1983).

Dessa forma compreendemos que a análise do contexto de cada sistema de ensino pesquisado nos fornece elementos para conhecermos o todo de cada realidade específica onde se inserem os sujeitos e suas representações sobre formação contínua.

$\mathrm{Na}$ busca por alcançar as representações e reconhecendo a singularidade de cada contexto educacional analisado, optamos, nos capítulos quatro, cinco e seis, por apresentá-los e analisá-los individualmente, a fim de que fossem estabelecidas relações entre os elementos que compõem cada cenário específico, procurando considerar os diversos aspectos que se ligam à questão da capacitação profissional em serviço em cada realidade específica. Conforme pondera Konder (1997, p. 58),

Tudo tem a ver com tudo, os diversos aspectos da realidade se entrelaçam e, em diferentes níveis dependem uns dos outros, de modo que as coisas não podem ser compreendidas isoladamente, uma por uma, sem levarmos em conta a conexão que cada uma mantém com coisas diferentes.

Ainda segundo o mesmo autor, a dialética não pensa o todo negando as partes, nem as partes extraídas do todo e, conforme esse pensamento, nosso esforço se deu no sentido de compreender a conexão íntima existente entre elas, alcançando as contradições. "Não podemos dizer ao mesmo tempo que determinado objeto é redondo e é quadrado. Mas devemos dizer que o mais se define com o menos, que a dívida se define pelo empréstimo" (LEFEBVRE, 1985 apud KONDER, 1997 p. 49).

Para obter uma gama de dados empíricos, procurarmos nos utilizar de diversos instrumentos de pesquisa, como survey, aplicado aos professores das três redes, 
entrevista semi-estruturada, realizada com três gestores (um gestor municipal, um diretor de escola e um coordenador pedagógico), bem como análise de possíveis documentos que pudessem favorecer a compreensão de cada realidade observada, no que tange aos processos de formação contínua dos três sistemas, em especial nos anos de 2012 e 2013.

Os questionários aplicados à totalidade dos professores do ensino fundamental das três redes e as entrevistas realizadas com os gestores se deu como base na literatura básica da área de formação de professores e foram elaborados concomitantemente, em momento anterior à coleta dos documentos analisados, tendo como principal objetivo apreender as representações desses sujeitos sobre o tema. Sua análise mereceu especial atenção, pois, conforme sinaliza Moscovici (1961), é na expressão da opinião sobre o objeto que se manifestam as representações sobre esse mesmo objeto. Desse modo, é preciso, segundo o autor, analisar não só o que é manifestado através da fala, mas o que essa mesma fala denota, ou seja, que posicionamentos, críticas ou desejos estão ocultos nessas mensagens.

Ainda no levantamento do contexto educacional, consideramos a evolução do Índice de Desenvolvimento da Educação Básica - IDEB - nas quatro últimas avaliações realizadas nas séries iniciais do ensino fundamental. $\mathrm{O}$ índice de desenvolvimento humano, o percentual de renda per capita, o orçamento dos municípios, o perfil de formação dos docentes de cada rede, além dos programas de formação continuada desenvolvidos por tais municípios, as decisões sobre o currículo e as formas de organizá-lo, puderam compor o grande panorama desta análise, em que procuramos confrontar dados concretos obtidos e as representações dos profissionais destas redes. Tal confrontação também se deu em nível de análise entre as realidades concretas desses municípios, procurando-se observar as implicações e os reflexos das atuais políticas de Estado, especialmente em nível nacional, na implementação das políticas em nível municipal.

A aproximação da pesquisadora na busca dos dados para a pesquisa se deu de maneira semelhante nas três redes de ensino. Inicialmente agendou-se uma visita junto ao Secretário de Educação de cada município, ocasião em que foram explanadas as intenções da pesquisa, requisitando-se autorização e colaboração em relação aos procedimentos a serem realizados. Os três gestores concordaram em participar, autorizando a aplicação de questionários e a realização das entrevistas, bem como comprometendo-se a fornecer os documentos solicitados. 
Nos três municípios, a pedido do Secretário, foi disponibilizado um funcionário da secretaria de educação, que enviou e recolheu os pacotes de questionários aplicados aos professores do ensino fundamental nas unidades escolares de cada rede.

No que tange ao fornecimento de documentos, o Sistema B e C atenderam prontamente, disponibilizando o que havia nas secretarias, como cronogramas de formação e outros registros relativos às atividades de formação contínua no município. No Sistema A, tais documentos não nos foram fornecidos, levando-nos a realizar nossa análise a partir do que havia disponível em sites oficiais.

Tal coleta de dados, forneceu-nos elementos para entendermos a trajetória educacional de cada município, considerando o caminho percorrido por cada um deles na construção de um sistema educacional autônomo, especialmente no que se refere ao desenvolvimento de programas de formação em serviço.

Num percurso de confrontação entre representações, conhecimento sistematizado, saber cotidiano e formas pessoais de entendimento pode operar o movimento lógico-dialético, transformador de representações em conhecimentos (PENIN, 1995). Considerando as representações como um conjunto de palavras e ações, procuramos analisá-las comparativamente, buscando entender em que medida o novo se faz presente no conjunto de ações desenvolvidas pelos municípios pesquisados. Em outras palavras, o que há de inovador, que pode representar a gênese da mudança e da construção de novos paradigmas em relação à formação docente em serviço e qual a força exercida pelas realidades particulares na concepção de formação em serviços desses docentes.

\subsection{Fonte de dados e critérios de análise}

\subsubsection{Survey}

Dentre os possíveis caminhos para a compreensão do comportamento humano no contexto das ciências sociais, apontamos o survey como um instrumento capaz de assegurar melhor representatividade, permitindo assim uma generalização mais ampla das representações dos professores sobre a formação contínua dos três municípios pesquisados.

Fink \& Kosecoff (1985) definem survey, termo inglês geralmente traduzido como levantamento de dados, como "método para coletar 
informação de pessoas acerca de suas ideias, sentimentos, planos, crenças, bem como origem social, educacional e financeira" (GUNTHER, 1999, p.231).

As perguntas contidas nesse questionário versaram sobre a importância que os professores atribuem ao processo de formação contínua de modo a detectar os fatores que motivam a sua participação, a avaliação que fazem das propostas de formação continuada na rede, a relevância que atribuem aos temas tratados e em que medida a percepção desses profissionais sobre o tema é modificada pelas circunstâncias impostas pela realidade à qual pertencem.

Dividimos o questionário em duas seções, sendo que a primeira procurou traçar o perfil de formação dos professores, como também o tempo de magistério e na unidade escolar em que atuam, além de descrever sua situação funcional. O conjunto de dados coletados sobre os aspectos acima mencionados trouxe-nos a possibilidade de identificar melhor os sujeitos envolvidos na pesquisa.

A segunda seção foi composta por questões que tiveram como objetivo identificar e analisar quais conceitos compõem a representação dos professores sobre o tema. Nesse sentido, estabelecemos duas categorias de orientação para a análise, a saber: 1. Fatores que mais motivam a participação na formação contínua; 2. Expectativas sobre formação contínua e sua relevância para a prática.

O primeiro item procura identificar as motivações dos professores para sua participação na formação contínua, abordando esse aspecto através da análise do que foi espontaneamente apontado também através de questões diretas apreendendo seu posicionamento em relação ao valor que atribuem à ligação entre formação contínua e valorização na carreira. Analisam-se, ainda neste item, suas repostas quanto à frequência nos cursos oferecidos e as informações sobre sua formação em nível de pósgraduação.

No segundo item, as questões que compuseram esta categoria de análise tinham como objetivo desvelar representações sobre formação contínua, considerando a manifestação dos professores em relação às suas expectativas quanto ao formato de cursos, áreas do conteúdo a serem contempladas e relevância desses cursos de formação para a prática pedagógica.

Ao perguntar aos professores sobre como veem a formação oferecida pelo município, se mais teórica ou mais ligada à prática, e ao questioná-los sobre qual o formato ideal de um curso de formação e, ainda, que temas deveriam ser abordados nas 
formações, nossa intenção era apreender que conceitos guiam sua forma de pensar o papel do professor no processo de formação permanente, se mais passivo ou ativo, através do desvelamento de seu grau de satisfação em relação ao desenvolvimento das propostas de formação. À medida que se manifestam em relação a essas propostas, também nos fornecem elementos para o entendimento da forma como acontecem.

Procuramos, ainda, detectar como percebem a contribuição dos cursos oferecidos em seu município para o enfrentamento dos desafios pedagógicos e, ainda, que outros fatores relacionados à formação, mesmo aquela desenvolvida na própria unidade, representam contribuições para a superação de tais desafios.

Considerando as representações como um conjunto de palavras e ações (LEFEBVRE, 1983), levantamos os dados relativos à frequência de participação nos cursos, aliada à análise de outros fatores como avaliação que fazem da proposta de formação e fatores motivacionais ligados à carreira, uma possibilidade de reflexão para além das falas desses professores, detectando os movimentos de contradição ali presentes. Há uma possibilidade de compreender como se comportam, como manifestam suas ações de forma concreta em relação ao tema em análise.

Os questionários foram impressos, empacotados por unidade escolar, e, após autorização do Secretário de Educação, encaminhados às unidades escolares do município. Conforme mencionado, não tivemos problemas nessa etapa do trabalho de pesquisa, uma vez que, nas três realidades pesquisadas, havia um funcionário da própria secretaria incumbido pelo secretário de educação de enviar e recolher os questionários. No entanto, o retorno dos pacotes não se deu de maneira semelhante nas três redes de ensino, uma vez que, como mostra a tabela, no Sistema B a devolutiva se deu de forma mais satisfatória que nos demais.

\section{Tabela 1 - Questionários enviados e devolvidos}

\begin{tabular}{|c|c|c|c|c|c|c|c|c|}
\hline \multicolumn{2}{|c|}{ Sistema A } & \multicolumn{3}{c|}{ Sistema B } & \multicolumn{3}{c|}{ Sistema C } \\
\hline Enviados & Devolvidos & $\%$ & Enviados & Devolvidos & $\%$ & Enviados & Devolvidos & $\%$ \\
\hline 343 & 212 & 62 & 343 & 327 & 95 & 146 & 85 & 58 \\
\hline
\end{tabular}


Os dados coletados foram organizados em forma de tabelas e quadros a partir dos eixos citados, além de terem sido destacadas as falas consideradas importantes para a orientação de análises qualitativas sobre os tópicos abordados.

\subsubsection{Entrevista semi-estruturada}

Além de apreender as representações que gestores das três redes de ensino possuem sobre a capacitação em serviço desenvolvida no município, as entrevistas semi-estruturadas também nos possibilitaram conhecer as propostas de formação de cada uma das realidades, especialmente nos aspectos que envolvem sua articulação entre as escolas de cada rede e o sistema municipal de ensino. Para tanto, em cada município foram realizadas três entrevistas, somando um total de nove, distribuídas do seguinte modo: uma com um representante da Secretaria de Educação ${ }^{4}$, indicado pelo Secretário como responsável pela formação continuada do Sistema, uma com um diretor de escola e uma com um coordenador pedagógico.

A entrevista é apontada como meio eficaz na obtenção de informação/realização da pesquisa, uma vez que, pela sua dimensão social, caracteriza-se pela interação linguística entre pesquisador e pesquisado, como afirma Freitas (2002, p. 9),

Ela não se reduz a uma troca de perguntas e respostas previamente preparadas, mas é concebida como uma produção de linguagem, portanto dialógica. Os sentidos são criados na interlocução e dependem da situação experienciada, dos horizontes especiais ocupados pelo pesquisador e pelo entrevistado. As enunciações acontecidas dependem da situação concreta em que se realizam, da relação que se estabelece com os interlocutores, depende de com quem se fala. $\mathrm{Na}$ entrevista é o sujeito que se expressa, mas sua voz carrega o tom de outras vozes, refletindo a realidade de seu grupo, gênero, etnia, classe, momento histórico e social.

A relevância desse tipo de instrumento de coleta de dados pode ser encontrada nos estudos de Manzini (1991), que busca explicitar seu alcance para a pesquisa científica:

\footnotetext{
${ }^{4}$ No texto nos referimos ao representante da secretaria de educação como gestor municipal, já que foi o indicado pelo secretário como representante do sistema no que se refere à condução das propostas de formação contínua. Esclarecemos que, em nenhum dos sistemas, a nomenclatura "gestor municipal" refere-se ao secretário de educação, ainda que não fossem colocadas restrições para que este participasse pessoalmente da pesquisa.
} 
$\mathrm{Na}$ entrevista semi-estruturada, a resposta não está condicionada a uma padronização de alternativas formuladas pelo pesquisador como ocorre na entrevista com dinâmica rígida. Geralmente, a entrevista semi-estruturada está focalizada em um objetivo sobre o qual confeccionamos um roteiro com perguntas principais, complementadas por outras questões inerentes às circunstâncias momentâneas à entrevista. $\mathrm{O}$ uso de gravador é comum a este tipo de entrevista. É mais adequada quando desejamos que as informações coletadas sejam fruto de associações que o entrevistado faz, emergindo, assim, de forma mais livre (Ibid. p. 154).

O quadro abaixo mostra o objetivo da entrevista, bem como os eixos que nortearam as suas questões.

\section{Quadro 1 - Objetivos e eixos da entrevista com gestores municipais e escolares}

\begin{tabular}{|c|c|}
\hline \multicolumn{2}{|c|}{ A formação continuada na perspectiva de gestores municipais } \\
\hline $\begin{array}{l}\text { Objetivo: } \\
\text { Apreender que representações } \\
\text { possuem os gestores entrevistados } \\
\text { sobre formação contínua em serviço, } \\
\text { compreendendo os modelos de } \\
\text { formação adotados pela rede de } \\
\text { ensino. }\end{array}$ & $\begin{array}{l}\text { Eixos orientadores das questões } \\
\text { - Diagnóstico e planejamento } \\
\text { - Execução e acompanhamento } \\
\text { - } \quad \text { Avaliação e registro }\end{array}$ \\
\hline
\end{tabular}

A escolha dos profissionais entrevistados foi concedida aos secretários de educação, que procederam à indicação. Com exceção das entrevistas realizadas com gestores do Sistema A, em que havia pessoas da equipe na mesma sala onde se realizou a entrevista ${ }^{5}$, as demais ocorreram em sala reservada, estando presentes somente o entrevistado e a entrevistadora.

No Sistema C, a entrevista com o gestor municipal foi realizada na sede da Secretaria de Educação, sendo que o coordenador pedagógico e o diretor de escola,

\footnotetext{
${ }^{5}$ Não descartamos a possibilidade de contaminação nos resultados obtidos a partir das entrevistas, uma vez que a presença de pessoas ligadas à equipe da Secretaria de Educação pode ter interferido nas manifestações das pessoas entrevistadas, sobretudo a coordenadora pedagógica e a diretora de escola. No entanto, houve curtos espaços de tempo em que os entrevistados ficavam a sós com a entrevistadora.
} 
ambos da mesma unidade, foram entrevistados na própria escola onde trabalham. Nos demais sistemas, as entrevistas foram realizadas na sede da Secretaria de Educação.

As entrevistas foram gravadas em áudio e transcritas uma a uma, na sequência de perguntas e respostas.

\subsubsection{Análise de documentos}

Reconhecendo a necessidade de obter dados concretos para serem confrontados com as falas obtidas nos questionários e entrevistas, buscamos juntar uma série de documentos que pudessem confrontar-se aos discursos. Para tanto, investigamos a presença de todo tipo de registro do processo de formação contínua, como cronogramas, atas de reuniões, registros de planejamento e avaliações, enfim, ações concretas que pudessem mensurar o quanto a formação contínua oferecida integra a vida cotidiana das escolas e interfere na representação que esses profissionais fazem .

Os documentos coletados das três secretarias de educação pesquisadas são aqueles que fazem referência às políticas de formação desenvolvidas nos municípios. Para isso, solicitamos através de ofício ao Secretário de Educação os seguintes documentos: Plano de Carreira do Magistério Público Municipal ou Plano de Carreira dos Servidores Públicos Municipais, organograma da estrutura pedagógica e administrativa da Secretaria de Educação (efetivos e em comissão), relação dos cursos de capacitação realizados em 2012 e 2013, contendo nome do curso, tema, duração, público-alvo, data e forma de avaliação e documentos oficiais da Secretaria de Educação que contivessem diretrizes curriculares e de formação de professores.

Conforme mencionamos, no Sistema A só tivemos acesso aos documentos disponibilizados em sites oficiais.

Entendemos que a coleta dos referidos documentos nos fornece subsídios para a caracterização da modalidade de formação oferecida, proporcionando uma análise baseada em elementos sólidos e que possibilitam uma confrontação com outros dados coletados, como o questionário aplicado aos professores e as entrevistas realizadas, conforme já mencionado. 


\subsubsection{Análise de Conteúdo}

Os dados foram analisados a partir de uma perspectiva qualitativa, apoiada nas concepções de análise de conteúdo proposta por Bardin.

A análise de conteúdo pode ser considerada como um conjunto de técnicas de análises de comunicações, que utiliza procedimentos sistemáticos e objetivos de descrição de conteúdo das mensagens (...). A intenção da análise de conteúdo é a inferência de conhecimentos relativos às condições de produção e de recepção das mensagens, inferência esta que recorre a indicadores (quantitativos ou não) (BARDIN, 1977 apud FRANCO, 2008, p. 24).

A metodologia de análise de conteúdo possibilita ao pesquisador um estudo que ultrapassa as aparências, as leituras superficiais, já que as mensagens presentes nos ambientes pesquisados (fala, escrita, documentos) possuem uma grande quantidade de informações sobre o seu autor. Nelas estão implícitas suas concepções de mundo, interesses e representações.

Ao mesmo tempo, entendemos que é preciso partir da análise dos dados empíricos para a exploração dos conteúdos da comunicação (tal como manifesto), evitando "uma análise baseada, apenas, em um exercício equivocado e que pode redundar na situação de uma mera projeção subjetiva" (FRANCO, 2008, p. 27).

A investigação baseada no conteúdo que ali está presente, não descartando a possibilidade de análise do conteúdo oculto nas mensagens e de suas entrelinhas, pode nos encaminhar para além do manifesto explicitamente, podendo ser decifrado por códigos especiais e simbólicos.

De forma lógica, o pesquisador, comportando-se como um arqueólogo ao analisar as manifestações, infere conteúdos que extrapolam o manifesto nas mensagens e podem estar associados a outros elementos do conteúdo de comunicação, permitindo a passagem da descrição para a interpretação.

Conforme afirma Bardin, o primeiro contato com o material de análise é a "leitura flutuante", em que são levantadas as questões norteadoras, fazendo com que surjam os temas recorrentes, como resultado de cada questão. Em cada um dos instrumentos utilizados (questionário, entrevista, coleta de documentos), elegemos os eixos orientadores dos temas a serem analisados conforme quadros explicitados anteriormente, a partir dos objetivos já delineados para esta pesquisa. Os eixos de 
análise foram estabelecidos segundo os critérios de recorte, categorização e codificação observados por Bardin (1999). 


\section{PARTE II - OS SISTEMAS DE ENSINO: AS RELAÇÕES ENTRE CONTEXTO E REPRESENTAÇÕES}

Nesta parte do trabalho encontram-se os principais dados desta pesquisa, detalhando-se, nos capítulos quatro, cinco e seis, em cada um dos Sistemas, sua legislação, estrutura de formação contínua disponível, forma de organização. Expomos, também, as manifestações de professores e gestores, analisando, em cada um dos Sistemas de ensino, como os diversos elementos se articulam considerando o binômio contexto e representações. No capítulo sete estão condensados os principais dados da análise, onde se analisam comparativamente os três sistemas ${ }^{6}$.

\footnotetext{
${ }^{6}$ A fim de preservar a identidade dos municípios, ao nos utilizarmos de legislação municipal omitimos nas citações no texto e nas referências o nome das cidades nas quais se inserem os Sistemas de ensino estudados.
} 


\section{O SISTEMA A}

\subsection{Contexto sócio-econômico, Estrutura da Secretaria de Educação e Plano de Carreira}

O Sistema A pertence a um município situado no noroeste paulista a aproximadamente quinhentos quilômetros da capital e foi fundado no ano de 1908.

Nascido a partir da expansão cafeeira, o município tem sua economia caracterizada pelo crescimento das lavouras de cana-de-açúcar, além representar importante pólo de criação de gado de corte. A região, a topografia, o solo e o clima para o cultivo de cana-de-açúcar, mão de obra especializada e a facilidade de escoamento de produção tornaram a cidade sede de um dos maiores terminais sucroalcooleiros do estado de São Paulo. Além disso, há forte predominância do setor de serviços na cidade. Apresenta, ainda, significativa vocação para o ramo industrial, já que se verificam na cidade empresas de processamento de leite, de extrato de tomate e de outras conservas, dentre outras. Os dados da tabela abaixo mostram os principais indicadores relacionados aos aspectos sócio-econômicos do município.

\section{Tabela 2: Dados sócio-econômicos do município}

\begin{tabular}{|c|c|c|c|c|c|}
\hline População & $\begin{array}{c}\text { Receita do } \\
\text { Município }\end{array}$ & $\begin{array}{c}\text { Renda per } \\
\text { Capita }\end{array}$ & IDHM & $\begin{array}{c}\text { IDHM } \\
\text { Educação }\end{array}$ & $\begin{array}{c}\text { Taxa de } \\
\text { Analfabetismo }\end{array}$ \\
\hline 184.491 & 407.215 .673 & 847,76 & 0,788 & 0,744 & 3,85 \\
\hline
\end{tabular}

Fonte: Fundação Seade. Consulta em 19/03/2014.

A cidade comporta diversas faculdades e, dentre elas, uma universidade pública. No entanto, o maior número de matrículas é registrado nas faculdades da rede privada, destacando-se as registradas nos cursos de direito, engenharia bem-estar social. Ainda que em menor número, há registro significativo na área de educação, medicina veterinária e ciências.

$\mathrm{Na}$ educação básica, o ensino médio e os quatro últimos anos do ensino fundamental estão sob responsabilidade da rede estadual de ensino, estando a cargo do município os segmentos de educação infantil e os anos iniciais do ensino fundamental. 
O gráfico a seguir apresenta o movimento das matrículas dos segmentos pertencentes à rede municipal de ensino entre os anos de 1999 a 2013.

Gráfico 3: Movimento das matrículas na rede municipal de 1999 a 2013
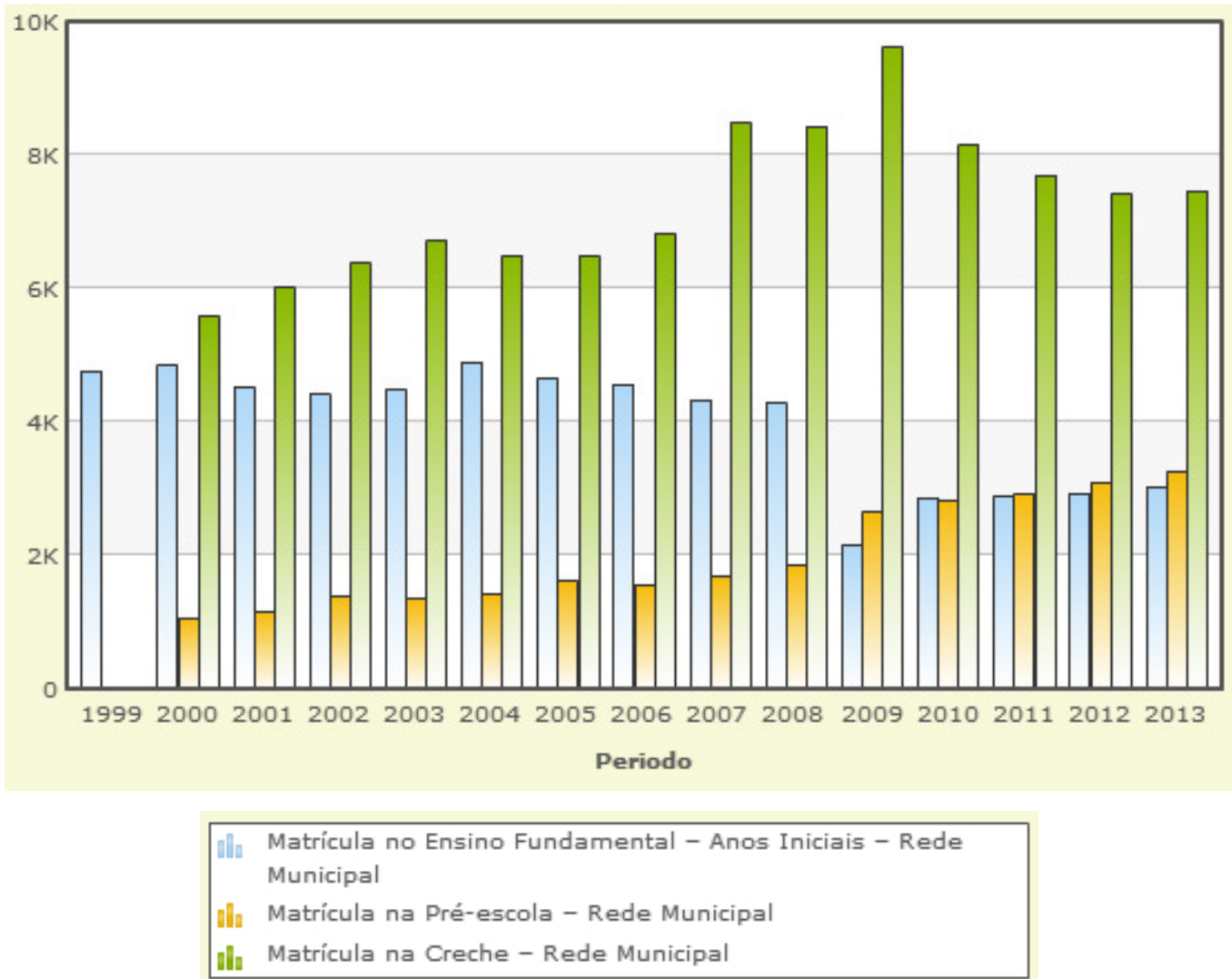

Fonte: Fundação Seade.

Os dados expostos no gráfico mostram o aumento de responsabilidades do município quando, a partir do ano 2000, tem em sua rede os alunos da primeira etapa do ensino fundamental, devido à municipalização do ensino. Nota-se, ainda, que no mesmo ano, a exemplo dos demais municípios brasileiros, o município passa a atender o segmento creche como uma etapa de ensino da educação básica, já que, até a promulgação da nova LDB, esse setor pertencia à assistência social. É possível perceber também uma diminuição das matrículas na etapa de pré-escola, que se deu, principalmente, devido à implantação do ensino fundamental de nove anos. O Sistema registrou, segundo o censo escolar de 2013, um total de 13.730 alunos, sendo 3.024 matriculados na etapa creche, 3.242 na pré-escola e 7.464 na primeira etapa do ensino fundamental. 
O sistema A é, dentre os três sistemas pesquisados, aquele que apresenta os menores progressos na evolução das notas do IDEB. Apresentando crescimento de apenas 0,4 pontos na trajetória da avaliação, um percentual consideravelmente inferior se comparado com os demais municípios da pesquisa e aos demais municípios brasileiros e paulistas, não consegue atingir a sua meta, que, em 2011, deveria ser de 5,8 .

\section{Quadro 2 - Resultado do IDEB - Sistema A}

\begin{tabular}{|c|c|c|c|c|c|c|c|c|c|c|c|c|}
\hline \multicolumn{5}{|c|}{ Ideb Observado } & \multicolumn{8}{|c|}{ Metas Projetadas } \\
\hline $\begin{array}{c}2005 \\
*\end{array}$ & $\begin{array}{c}2007 \\
*\end{array}$ & $\begin{array}{c}2009 \\
=\end{array}$ & $\begin{array}{c}2011 \\
*\end{array}$ & $\begin{array}{c}2013 \\
*\end{array}$ & $\begin{array}{c}2007 \\
=\end{array}$ & $\begin{array}{c}2009 \\
=\end{array}$ & $\begin{array}{c}2011 \\
*\end{array}$ & $\begin{array}{c}2013 \\
*\end{array}$ & $\begin{array}{c}2015 \\
*\end{array}$ & $\begin{array}{c}2017 \\
*\end{array}$ & $\begin{array}{c}2019 \\
\quad\end{array}$ & $\begin{array}{c}2021 \\
=\end{array}$ \\
\hline 5.1 & 5.3 & 5.5 & 5.6 & 5.8 & 5.2 & 5.5 & 5.8 & 6.1 & 6.3 & 6.5 & 6.8 & 7.0 \\
\hline
\end{tabular}

Fonte: Inep

Os índices apresentados pelo sistema A superam a média das escolas municipais brasileiras, que é de 4,9, do mesmo modo que também superam a média das escolas brasileiras que atendem os anos iniciais do ensino fundamental, que é de 5.2.

Como se nota em relação ao índice alcançado em 2013, o sistema municipal acrescenta dois décimos à nota obtida em 2011, passando de 5.6 para 5.8. No entanto, não atinge a meta projetada para o município, que é de 6,1. Das vinte e cinco unidades do sistema de ensino que atendem a esta modalidade de ensino, apenas 7 atingem a meta prevista.

No que se refere ao aprendizado da língua, especialmente na competência leitora e interpretação de textos, $56 \%$ das crianças têm, segundo avaliação de 2013, um aprendizado adequado, percebendo-se um aumento de 8 pontos percentuais em relação à última avaliação. Em relação ao percentual de alunos com aprendizado insuficiente, o número obtido é de $11 \%$, três pontos percentuais a menos que a avaliação anterior neste nível.

Ainda em relação ao aprendizado da língua, nota-se, dentre as escolas da rede, evidente disparidade entre as notas obtidas, já que o desempenho observado varia de $33 \%$ (menor nota) a $80 \%$ ( maior nota ) de aprendizado adequado.

Em matemática o desempenho é inferior ao do ensino da língua em toda a rede - 47\% de aprendizado adequado -, notando-se a mesma disparidade em relação ao 
aprendizado adequado. $26 \%$ na menor nota contra $72 \%$, na maior nota obtida. Embora seja notado um avanço de 2 pontos em relação ao aprendizado da matemática, o percentual de alunos com aprendizado insuficiente permanece o mesmo, $16 \%$ com quase nenhum aprendizado.

A referida Secretaria de Educação possui uma estrutura dividida da seguinte forma: Conselhos Municipais, Departamentos e Serviços de Assessoria. Os Conselhos vinculados à pasta são: o Conselho Municipal de Educação, o Conselho do FUNDEB e o Conselho de Alimentação Escolar.

A seguir, descreveremos como estão organizados os referidos departamentos e assessorias da Secretaria Municipal de Educação:

\section{Quadro 3 - Estrutura de organização da Secretaria de Educação do Sistema $\mathrm{A}^{7}$}

\begin{tabular}{|l|l|}
\hline Ouvidoria da Secretaria Municipal de Educação \\
\hline Função: Atuar como canal de comunicação entre os munícipes e a gestão municipal. \\
\hline Setores & $\begin{array}{l}\text { 1. Assessoria Planejamento e Elaboração de Projetos de Educação. } \\
\text { 2. Serviço de Avaliação e Controle. }\end{array}$ \\
\hline Departamento de Educação Municipal \\
\hline Função: Formular políticas, estratégias e planos para o Sistema Municipal de Ensino. \\
\hline Setores & $\begin{array}{l}\text { 1. Divisão de Educação Infantil. } \\
\text { 2. Serviço de Coordenação Pedagógica da Educação Infantil. }\end{array}$ \\
$\begin{array}{l}\text { 3. Divisão de Ensino Fundamental. } \\
\text { 4. Serviço de Coordenação Pedagógica do Ensino Fundamental. } \\
\text { 5. Divisão de Educação Especial Inclusiva. } \\
\text { 6. Serviço de Coordenação Pedagógica da Educação Especial e Inclusão. }\end{array}$ \\
\hline Departamento de Supervisão do Ensino \\
\hline $\begin{array}{l}\text { Função: Supervisionar o Sistema Municipal de Ensino através do acompanhamento, assessoramento, a } \\
\text { avaliação e a pesquisa do processo administrativo e pedagógico das unidades educacionais do sistema. }\end{array}$ \\
\hline
\end{tabular}

\footnotetext{
${ }^{7}$ Todos os Departamentos possuem um diretor e eles ocupam a mesma posição hierárquica na SME, estando acima de todos eles o chefe da pasta, o Secretário Municipal de Educação. Ressalta-se que, entre todos os cargos e funções apresentados no organograma da SME, somente os Supervisores de Ensino (Departamento de Supervisão de Ensino) e os Terapeutas Ocupacionais e Psicólogos (Assessoria Multidisciplinar) ocupam cargos efetivos, com nomeação por concurso público. Orientadores Pedagógicos (Serviço de Coordenadoria) ocupam funções resultantes de processo seletivo de provas e projetos. Os demais profissionais do organograma (efetivos ou não na rede municipal) ocupam cargos comissionados ou funções gratificadas (ASSIS, 2014).
} 


\begin{tabular}{|c|c|}
\hline Setores & $\begin{array}{l}\text { 1. Assessoria Multidisciplinar. } \\
\text { 2. Divisão de Avaliação. } \\
\text { 3. Serviço de Avaliação Institucional. } \\
\text { 4. Serviço de Avaliação Pedagógica. }\end{array}$ \\
\hline \multicolumn{2}{|c|}{ Departamento de Educação Complementar } \\
\hline \multicolumn{2}{|c|}{$\begin{array}{l}\text { Função: Desenvolver a qualificação para o trabalho, a educação complementar e os cursos } \\
\text { profissionalizantes. }\end{array}$} \\
\hline Setores & $\begin{array}{l}\text { 1. Divisão de Educação para o Trabalho. } \\
\text { 2. Divisão de Educação de Jovens e Adultos. } \\
\text { 3. CEMFICA - TV. } \\
\text { 4. CEMFICA C SU. } \\
\text { 5. CEMFICA SOLAR. }\end{array}$ \\
\hline \multicolumn{2}{|c|}{$\begin{array}{l}\text { Departamento de Formação Contínua de Professores e Funcionários e de Desenvolvimento de } \\
\text { Tecnologias Educacionais }\end{array}$} \\
\hline \multicolumn{2}{|c|}{$\begin{array}{l}\text { Função: Formação dos docentes e demais servidores da educação de forma contínua e no } \\
\text { desenvolvimento do uso de novas tecnologias na educação. }\end{array}$} \\
\hline Setores & $\begin{array}{l}\text { 1. Divisão de Coordenação e Pesquisa de Novas Tecnologias na Educação da Secretaria de } \\
\text { Educação. } \\
\text { 2. Serviço de Formação Continuada de Professores. } \\
\text { 3. Serviço de Capacitação em Novas Tecnologias em Educação. }\end{array}$ \\
\hline \multicolumn{2}{|c|}{ Departamento de Serviços de Apoio à Educação } \\
\hline \multicolumn{2}{|c|}{$\begin{array}{l}\text { Função: Formular e avaliar os serviços de apoio ao aluno e à comunidade escolar na área de } \\
\text { alimentação e transporte. }\end{array}$} \\
\hline Setores & $\begin{array}{l}\text { 1 Divisão de Assistência Técnica na Secretaria de Educação. } \\
\text { 2.Serviço de Alimentação Escolar. } \\
\text { 3. Serviço de Armazenagem, Distribuição e Controle. } \\
\text { 4. Serviço de Manutenção e Fiscalização do Transporte Escolar. } \\
\text { 5. Serviço do Controle de Frota e do Transporte. } \\
\text { 6. Serviço Expediente e Apoio Administrativo. }\end{array}$ \\
\hline \multicolumn{2}{|c|}{ Departamento de Apoio Administrativo e Financeiro } \\
\hline \multicolumn{2}{|c|}{$\begin{array}{l}\text { Função: Prover os recursos materiais, humanos e financeiros, necessários à prestação dos serviços } \\
\text { municipais de educação. }\end{array}$} \\
\hline Setores & $\begin{array}{l}\text { 1. Serviço de Arquivo, Imagem e Som. } \\
\text { 2. Serviço de Informática. } \\
\text { 3.Divisão de Gestão. } \\
\text { 4. Serviço de Gestão dos Recursos Humanos. } \\
\text { 5. Serviço de Controles Contábeis e Financeiros. } \\
\text { 6. Serviço de Gestão de Recursos Materiais, Equipamentos Mobiliários e de Manutenção } \\
\text { Física da Rede. }\end{array}$ \\
\hline
\end{tabular}

Fonte: Site oficial do município 
Os Departamentos e Serviços de Assessoria dessa Secretaria de Educação apresentam, a nosso ver, um quadro bastante generoso quanto às possibilidades de oferecer uma estrutura completa às unidades de ensino atendidas pelo município.

O plano de carreira do município em que se insere o Sistema A foi reformulado no ano de 2009, através de lei complementar, e representa uma legislação bastante completa, já que consegue abarcar quase a totalidade das situações previstas no campo de atuação profissional, chegando ao extremo de ter incluídos profissionais como secretários de escola, psicólogos e enfermeiros, que atuam junto às unidades, no conjunto dos profissionais contemplados.

Não é intento analisar todas as particularidades do referido documento. Aternos-emos, apenas, aos aspectos da lei que fazem referência à formação de professores, seja na forma como esta compõe a jornada do professor, seja na forma de progressões e incentivos na carreira, constituindo-se em fatores que podem estar interferindo na representação que esses profissionais possuem sobre o assunto.

Consta como jornada de trabalho dos professores do Sistema A o conjunto das atividades desenvolvidas com os alunos, as horas de trabalho pedagógico coletivo HTPC, as horas de trabalho no desenvolvimento de projetos e pesquisa da unidade escolar de interesse pedagógico da comunidade escolar - HTPP e horas de trabalho em local de livre escolha. Há, ainda, o HTFC - Horas de Trabalho de Formação Contínua, destinadas aos professores de educação especial.

As HTPCs têm a finalidade de constituir-se num espaço de formação contínua em serviço e acontecem nas próprias unidades escolares, locais onde também ocorrem os HTPPs, que se destinam à elaboração de projetos e pesquisas, à articulação com a comunidade e ao aperfeiçoamento profissional de acordo com a proposta pedagógica. As HTFCs podem acontecer em locais distintos, como na própria escola e na sede da secretaria de educação.

As horas dedicadas à formação em serviço, vinculadas à jornada de trabalho, estão assim especificadas: 


\section{Quadro 4 - Programas de Formação Contínua previstos na jornada de trabalho dos professores do Sistema A}

\begin{tabular}{|c|c|c|}
\hline Programa & Contemplados & $\begin{array}{c}\text { Horas dedicadas } \\
\text { semanalmente }\end{array}$ \\
\hline HTPC & Todos os professores ${ }^{8}$ da rede & 2 \\
\hline HTPP & $\begin{array}{c}\text { Professores com jornada de trabalho } \\
\text { semanal de 30 horas ou mais }\end{array}$ & 2 \\
\hline HTFC & $\begin{array}{c}\text { Professores de Educação Básica II - } \\
\text { Educação Especial }\end{array}$ & 6 \\
\hline
\end{tabular}

Fonte: Lei complementar oficial do município

Além da formação em serviço integrada à jornada de trabalho, a lei complementar que estabelece o plano de carreira traz consigo outros incentivos à formação contínua, uma vez que um de seus artigos indica a formação com aspecto da valorização do professor.

Formação permanente e sistemática de todo o pessoal do quadro dos profissionais da educação básica, promovida pela Secretaria Municipal da Educação ou realizada por universidades ou instituições de ensino de nível superior (Art. 58, LEI COMPLEMENTAR).

$\mathrm{O}$ art. 59 explicita a possibilidade de que os professores possam frequentar cursos de formação, atualização e especialização profissional, desde que condicionados aos interesses da administração municipal.

É também possível que 5 (cinco) profissionais efetivos da educação básica que tenham sido aprovados em processo seletivo específico tenham direito, anual e concomitantemente, a afastamento sem prejuízo de vencimentos e das demais vantagens do cargo, para frequentar cursos de pós-graduação stricto-sensu no prazo máximo de 18 (dezoito) meses. Ainda assim, aqueles que não se enquadrarem nessa opção poderão, ao

\footnotetext{
${ }^{8}$ Compõem a classe dos docentes: PEB I - Professor de Educação Básica I (professores de educação infantil e ensino fundamental, séries iniciais regular e supletivo); PEB II - Professor de Educação Básica II ( Professores de Educação Especial, professores de educação física e artes) e Tradutor e intérprete de libras na educação básica. A classe de especialistas é composta de Diretores de escola e Supervisores de ensino, todos contratados por concurso público. Além desses, estão previstas as funções de coordenador pedagógico e orientador pedagógico, ocupados por profissionais efetivos do magistério público municipal mediante processo seletivo interno com nomeação prevista para dois anos, renovável por mais dois. Os coordenadores pedagógicos atuam diretamente nas unidades escolares e os orientadores pedagógicos ficam sediados na secretaria de educação atuando na seguinte quantidade e núcleos: 03 para os núcleos de Educação Infantil e Creche, 3 para o núcleo de Ensino Fundamental, 4 para o núcleo de Educação Especial na perspectiva da inclusão e 2 para o núcleo de Planejamento, Assistência Técnica e Avaliação.
} 
frequentarem cursos de doutorado, mestrado, pós-graduação, aperfeiçoamento, especialização ou atualização, no país ou no exterior, afastar-se sem vencimentos, mas sem prejuízo das vantagens do cargo.

Os professores do Sistema A também podem obter progressões na carreira através da apresentação de certificados de cursos válidos, ou seja, que apresentem carga horária mínima de 30 horas e que sejam realizados pela secretaria de educação ou reconhecidos por órgãos oficiais, devendo estar voltados ao campo de atuação do profissional.

A progressão na carreira nessa modalidade acontece a cada quatro anos e tem por objetivo reconhecer a dedicação do profissional da educação básica de carreira que está sempre se atualizando, aprimorando seus conhecimentos com vistas à melhoria da qualidade do ensino e da aprendizagem (Art. 53, LEI COMPLEMANTAR). Obterão progressão aqueles que realizarem $100 \%$, ou seja, 210 horas de cursos e não possuírem faltas injustificadas durante três anos, sendo acrescidos $2 \%$ em seu salário-base.

Analisamos, ainda, em que medida o tema formação contínua em serviço aparece descrito nas atribuições dos cargos, nos termos da lei complementar.

\section{Quadro 5 - Atribuições no processo de formação contínua referentes aos} cargos do magistério público municipal

\begin{tabular}{|l|l|}
\hline \multicolumn{1}{|c|}{ Cargos } & Atribuições no processo de formação contínua \\
\hline PEB II - Educação Especial & $\begin{array}{l}\text { a) indicar ao SEE as áreas de sua atuação } \\
\text { profissional que necessitam de melhora na } \\
\text { formação, inclusive indicando cursos, instituições } \\
\text { e/ou nomes de profissionais que possam vir ao } \\
\text { encontro das suas necessidades; b) promover a } \\
\text { formação continuada para os professores do } \\
\text { atendimento especializado e para os professores do } \\
\text { ensino comum, visando ao entendimento das } \\
\text { diferenças e para a comunidade escolar em geral; } \\
\text { c) participar das HTPCs, HTPP e HTFCs; d) } \\
\text { participar de cursos e outros eventos ligados a sua } \\
\text { área de atuação. }\end{array}$ \\
\hline DIRETOR DE ESCOLA & $\begin{array}{l}\text { Coordenar, no âmbito da escola, as atividades de } \\
\text { planejamento, avaliação e desenvolvimento } \\
\text { profissional. }\end{array}$ \\
\hline COORDENADOR PEDAGÓGICO & $\begin{array}{l}\text { Planejar, organizar e efetivar as horas de trabalho } \\
\text { coletivo HTPC e as horas de trabalho de } \\
\text { desenvolvimento de projetos e pesquisas - HTPP, } \\
\text { sob a supervisão do diretor de escola, de modo que } \\
\text { este momento contribua para a formação contínua } \\
\text { dos profissionais da unidade escolar. }\end{array}$ \\
\hline ORIENTADOR PEDAGóGICO & $\begin{array}{l}\text { Orientar as atividades de estudo e pesquisa, em } \\
\text { momentos de formação, para os profissionais da } \\
\text { educação básica. }\end{array}$ \\
\hline
\end{tabular}

Fonte: Lei complementar 204/2009. 
Observamos que as ações de formação aparecem mais direcionadas como responsabilidade dos coordenadores pedagógicos, orientadores pedagógicos e professores de educação básica da educação especial, aparecendo, enquanto atribuição do cargo, de forma muito genérica no caso do diretor de escola e inexistindo enquanto atribuições dos supervisores de ensino.

No mesmo ano da reformulação da citada lei, a secretaria de educação tornou público o seu Projeto Político Pedagógico Institucional, o PPPI. Assis (2014) o define com um documento com uma

(...) visão ideológica de educação proposta (...) em conformidade com a concepção de educação progressista, aquela indicada por Freire (2002), que, em síntese, consiste na educação formadora da pessoa crítica, capaz de refletir, dialogar, se posicionar diante das diversas situações de sua realidade e seu entorno (ASSIS, 2014).

A autora relata em seu trabalho o processo de construção do referido documento, construído em conjunto pelos profissionais da secretaria de educação a partir dos dados levantados junto às escolas. Dessa forma, o documento serviu como elemento referência na construção dos Projetos Políticos Pedagógicos - PPP das unidades escolares. Conforme aponta o documento, a intenção é que representasse

um fio condutor tão objetivo quanto possível para que o próprio órgão e as escolas do município, sob sua responsabilidade, possam buscar a sua própria identidade e autonomia, por meio da construção do seu projeto político-pedagógico. Suas bases filosóficas, objetivos e diretrizes para ação estão em consonância com a perspectiva de atendimento, baseada nos eixos do Plano Nacional de Educação PNE (LEI COMPLEMENTAR 204/2009).

O documento elaborado pelo Sistema A traz uma série de objetivos e metas a serem alcançados para a melhoria da qualidade do ensino. Destacamos, a seguir, o quadro elaborado por Assis (2014) em que demonstra as ações previstas para os quatro anos subsequentes, incluindo cronograma para execução. 


\section{Quadro 6 - Metas e ações para a formação continuada dos profissionais da educação do Sistema A}

\begin{tabular}{|c|c|c|c|c|c|}
\hline \multirow{2}{*}{\multicolumn{2}{|c|}{$\begin{array}{l}\text { Meta: Capacitar todos os envolvidos direta ou } \\
\text { indiretamente com a educação, por meio de formação } \\
\text { continuada, garantindo que o processo se desenvolva } \\
\text { anualmente. }\end{array}$}} & \multicolumn{4}{|c|}{ Cronograma de Execução } \\
\hline & & 2009 & 2010 & 2011 & 2012 \\
\hline \multirow{6}{*}{ Ações } & $\begin{array}{l}\text { Formação continuada dos gestores, supervisores, } \\
\text { coordenadores, diretores de divisão de ensino e } \\
\text { técnicos educacionais. }\end{array}$ & $\mathbf{X}$ & $\mathbf{X}$ & $\mathbf{X}$ & $\mathbf{X}$ \\
\hline & $\begin{array}{l}\text { Qualificação adequada aos profissionais da } \\
\text { Educação Infantil, por meio do acesso ao nível } \\
\text { superior e da capacitação em serviço. }\end{array}$ & $\mathbf{X}$ & $\mathbf{X}$ & $\mathbf{X}$ & $\mathbf{X}$ \\
\hline & $\begin{array}{l}\text { Capacitação dos docentes do Ensino Fundamental } \\
\text { com aprofundamento de estudos atualizados que } \\
\text { possibilitem o atendimento, sem traumas, da } \\
\text { criança de } 06 \text { anos ingressante neste nível de } \\
\text { ensino e das demais, em seus processos de } \\
\text { aprendizagem. }\end{array}$ & $\mathbf{X}$ & $\mathbf{X}$ & $\mathbf{X}$ & $\mathbf{X}$ \\
\hline & $\begin{array}{l}\text { Colocação nas escolas de acervo de literatura } \\
\text { infantil e infanto-juvenil, de obras e textos } \\
\text { científicos, de livros indicados como referenciais } \\
\text { teóricos para a prática docente, com objetivo de } \\
\text { auxiliar nos estudos e escolha de temas para as } \\
\text { atividades de HTPC, proporcionando aos } \\
\text { professores um ambiente de leitura e formação } \\
\text { contínua. }\end{array}$ & $\mathrm{X}$ & $\mathrm{X}$ & $\mathrm{X}$ & $\mathrm{X}$ \\
\hline & $\begin{array}{l}\text { Capacitação de todos os funcionários da Secretaria } \\
\text { Municipal de Educação e das unidades escolares } \\
\text { que prestam serviços no atendimento ao público, } \\
\text { visando ao fortalecimento da identidade } \\
\text { institucional e da proposta de uma cidade } \\
\text { educadora. }\end{array}$ & $\mathrm{X}$ & $\mathrm{X}$ & $\mathrm{X}$ & $\mathrm{X}$ \\
\hline & $\begin{array}{l}\text { Previsão de realização e participação de/em } \\
\text { Seminários, Congressos, Encontros, Palestras, } \\
\text { cursos e outros movimentos/ações destinados à } \\
\text { atualização de conhecimentos voltados para a área } \\
\text { da Educação. }\end{array}$ & $X$ & $\mathrm{X}$ & $\mathrm{X}$ & $\mathrm{X}$ \\
\hline
\end{tabular}

Fonte: Assis, 2014, adaptado. 
Como se observa, o PPPI prevê ações de formação contínua para todos os profissionais que atuam na educação municipal. No entanto, embora a forma de elaboração, inclusive com estabelecimento de cronograma de execução a ser cumprido, procure demonstrar o comprometimento na realização de ações de formação, não oferece, a nosso ver, ações concretas que um cronograma de execução exigiria. Da mesma forma, a análise da íntegra do referido documento não identifica a concepção de formação de professores em que se pautam tais ações, representando, segundo nossa crença, nada mais do que um conjunto de diretrizes muito genéricas que não podem fornecer às unidades escolares um direcionamento claro do que fazer.

Mais adiante, ao procedermos a uma análise das representações dos professores e gestores municipais, bem como das ações concretas de formação dos anos de 2012 e 2013, poderemos clarificar melhor essa nossa hipótese sobre a condução das políticas públicas de formação do Sistema A. Por hora, nossa percepção é que o sistema está amparado por uma lei complementar e um conjunto de diretrizes que trazem em seu escopo a clara preocupação com a questão da formação em serviço e a valorização de seus profissionais.

\subsection{A proposta de formação do Sistema A}

A análise das propostas de formação do sistema A se deu a partir das entrevistas realizadas, bem como dos documentos obtidos através de site oficial do município, já que não nos foram fornecidos pela secretaria de educação os cronogramas de formação referentes aos anos de 2012 e 2013, conforme solicitado.

Dessa forma, a análise aqui tecida sobre os programas de formação contínua desenvolvidos no município se dará com base nas entrevistas realizadas com a gestora municipal, indicada pelo secretário para falar sobre a formação do município, como também pelas duas gestoras municipais, uma diretora de escola e uma coordenadora pedagógica, também indicadas pela secretaria de educação.

Ao relatarem as práticas de formação existentes, especialmente entre os professores do ensino fundamental, as gestoras apontaram basicamente três ações: a) os momentos de estudo previstos na jornada de trabalho, os HTPCs e os HTPPs; b) o curso 
Ler e Escrever ${ }^{9}$, ministrado aos coordenadores da rede, quinzenalmente; c) o PNAIC ${ }^{10}$, desenvolvido pela equipe da secretaria de educação junto aos professores do $1^{\circ}$ ao $3^{\circ}$ ano.

Pelo que se pode depreender das entrevistas, os HTPCs são, basicamente, desenvolvidos nas unidades escolares a partir das diretivas do curso Ler e Escrever, ministrado quinzenalmente aos coordenadores pedagógicos, que repassam seu conteúdo aos professores nas escolas. No caso do PNAIC, as atividades são realizadas em horário diverso ao da jornada de trabalho.

Os conteúdos ministrados nos cursos focam essencialmente as áreas de língua portuguesa e matemática, muito embora a ênfase dada pela gestora municipal seja na área de língua portuguesa, em especial a alfabetização e o letramento, e seu conteúdo programático e metodologia vêm formatados pelas instituições detentoras do arcabouço teórico desses cursos, no caso, a Secretaria de Estado da Educação e o Ministério da Educação. Em relação às concepções teóricas presentes nos dois programas, não houve manifestações por parte das gestoras entrevistadas.

Mesmo não listando inicialmente dentre as ações de formação do município, a gestora municipal faz uma importante referência ao que considera também uma ação formativa. Trata-se das capacitações oferecidas através do programa "Amigos do Zip", que, segundo a gestora traz, uma abordagem curricular transversal, trabalha questões ligadas a áreas das emoções, estimulando a criança a perceber-se e a se posicionar diante das dificuldades. Segundo ela, a parceria se dá por meio de contratação de uma empresa privada, que prevê dentre suas ações capacitar os professores para que desenvolvam o projeto junto aos alunos do primeiro ao terceiro ano.

Ao questionarmos como o Sistema planeja seus projetos de formação contínua, foi apontada a realização de duas reuniões que se fazem com os diretores de escola, uma a cada semestre. Além desses dois momentos em que a equipe da secretaria se reúne com os diretores, a gestora municipal apontou o que denomina "processo diagnóstico" como elemento norteador do planejamento das capacitações a serem desenvolvidas pela secretaria.

\footnotetext{
${ }^{9}$ Programa do Governo do Estado de São Paulo, que funciona em parceria com os sistemas municipais de ensino.

${ }^{10}$ Programa Nacional de Alfabetização na Idade Certa, realizado em parceria com o Governo Federal e Universidades.
} 
Desde que eu entrei, que foi em 2009, sempre temos reuniões da Secretaria, buscando verificar as fragilidades que estão acontecendo com o município. Em 2010 nós começamos o nosso processo diagnóstico. Esse processo diagnóstico visava fazer realmente uma avaliação, não era só uma verificação de onde as crianças estavam, mas, fazendo essa avaliação, e tendo tomado essas decisões sobre o que as crianças não estavam atingindo. Sendo assim, observar o que os professores que estavam com dificuldade de ensinar e nesse sentido, fazer uma proposta de formação pra que nós pudéssemos subsidiar esses professores. Então desde que eu estou como orientadora, a proposta da secretaria é sempre nesse norte. De nós estarmos olhando, percebendo através de reuniões, das visitas nas escolas, analisando semanário, e nesse processo diagnóstico, o que nós precisávamos oferecer aos professores pra estar dando um suporte no ensino, porque nós sabemos que tanto a criança tem o direito de aprender quanto o professor o direito de saber ensinar. Então é mais ou menos nessa visão e dessa forma que a gente vem pensando na formação. (GMSA)

Então, esses olhares que a gente obtinha nesses resultados, conversando sobre todo o processo final de diagnóstico, fazemos um relatório do que a gente percebeu na escola. Nós chamamos os diretores pra conversar e nós dialogamos no sentido: "olha foi esse o resultado o que você percebeu sobre isso? E dentro disso: o que você percebeu sobre isso", era possível pontuar quais situações privilegiaram, aquele resultado ou quais eram ações que as escolas tiveram e que precisava mais de suporte. Então achei uma situação bem assim, produtiva, porque permitia esse diálogo da gente estar analisando o resultado, e depois pensando no ano que vem.O que vocês acham importante, o que nós podemos pensar pro ano que vem? Então íamos pensando juntos sobre o que seria, o que precisaria estar sendo fortalecido. Então em cima do que a gente percebia desse diálogo, cada diretor e coordenador de escola, que realizou também com seus professores é que íamos pensando nas formações. (GMSA)

Segundo a gestora, o referido processo diagnóstico seria o mecanismo de planejamento da formação contínua que partiria das principais defasagens de aprendizagem observadas nos alunos e nas dificuldades de ensino dos professores, muito embora não consiga relatar de forma objetiva como isso acontece. Não explicita nenhuma sistematização para tal, evidenciando certo improviso e ausência de participação mais organizada por parte dos professores e gestores da rede.

Tais impressões se fortalecem pelo que se depreende da fala da coordenadora pedagógica em relação ao planejamento das formações contínuas no município, já que não lhe parece claro como a secretaria de educação planeja suas ações. 
Não. Não. Também eu não tenho acesso ao que elas têm, o que é oferecido, eu acho que isso fica a cargo da própria equipe pedagógica, de estar decidindo, vendo os cursos que são acessíveis e que elas querem estar colocando à disposição, oferecendo. (CPSA)

A ideia de um planejamento pouco claro e sistematizado se reforça na fala da própria gestora do município ao declarar o posicionamento da equipe em relação à formação desenvolvida junto aos professores dos quartos e quintos anos.

(...) lembra que eu falei que vamos verificando? A nossa equipe conversou sobre isso na semana passada, que os professores do quartos e quintos anos nós precisamos agora estar envolvendo. Por quê? Porque nós percebemos uma fragilidade maior. Tava do primeiro ao terceiro e a gente tentou socorrer. Nós percebemos que agora o primeiro e o terceiro já estão numa estrutura, nós vamos percebendo uma tranquilidade, não sei se assim posso dizer. Uma situação que já está tendo um alicerce, já está tendo um resultado, sim. Nós já estamos percebendo isso. Em contrapartida nós percebemos que os quartos e quintos anos estão precisando agora do nosso apoio. (GMSA)

Os indícios que nos levam a ponderar sobre a ausência de propostas e ações de formação pensadas pela rede de ensino a partir de suas necessidades sustentam-se também na fala da coordenadora pedagógica, ao demonstrar certa angústia pela falta de suporte que percebe na área. Ao ser perguntada sobre a existência de outras modalidades de formação oferecidas é enfática: "Não, não há." Em outra fala, acrescenta:

A rede precisava estar elaborando mesmo um programa de formação continuada. Eu acho que fica muito restrito quando você trabalha dentro da reflexão do próprio grupo, aquilo que os iguais pensam. Eu acho que fica muito dentro do igual. Não temos uma formação de pessoas, que, por exemplo, que faz, por exemplo, um mestrado, que trabalha mesmo com essa visão. (CPSA)

Não é nosso objetivo nesse momento estabelecer críticas com relação ao conteúdo e à metodologia ou relevância dos cursos ofertados. No entanto, chama-nos a atenção a falta de "autoria" ou até mesmo, ousamos dizer, de um projeto de formação que não esteja restrito ao "repasse" de cursos já formatados, sem que os mesmos passem por uma reflexão crítica, adequando-se à realidade.

Além de não ficarem claros os processos de planejamento da formação, e tampouco as formas de acompanhamento, a falta de articulação a um projeto maior 
também é detectada pelo fato de que a gestora municipal não faz referência, em nenhum momento, às diretrizes de formação do município, que tinham como meta "capacitar todos os envolvidos direta ou indiretamente com a educação, por meio de formação continuada, garantindo que o processo se desenvolva anualmente" (METAS E AÇÕES PARA A FORMAÇÃO CONTINUADA DOS PROFISSIONAIS DE EDUCAÇÃO DO SISTEMA A apud ASSIS, 2014). Além disso, nos parece, no mínimo, estranho, o fato de existir na estrutura organizacional da secretaria o "Departamento de Formação Contínua de Professores e Funcionários e de Desenvolvimento de Tecnologias Educacionais", sem que seu papel tenha sido considerado no relato das ações de formação contínua do município.

Nesse sentido, ainda é possível perceber a ausência de um projeto de formação articulado entre os formadores que atuam nos diversos segmentos atendidos pelo município. Ao ser questionada sobre o trabalho de formação desenvolvido junto aos professores da educação infantil, soube apenas informar que se trata de um projeto importado de outra cidade, cuja formação nele se encerra.

O conjunto de ações de formação descritas revela um contexto de ações fragmentadas, cujos responsáveis parecem isolados e desconectados de um projeto maior. Pelo que se pode inferir, não está claro para o sistema de ensino a ideia de formação contínua como um processo articulado entre toda a rede, que preveja a relação entre teoria e prática através de ações de planejamento, acompanhamento e avaliação sistematizados em que se faça notar uma presença mais autônoma da gestão municipal na condução das políticas de formação do município.

Como já mencionado antes, ao apresentarmos a legislação do ponto de vista da formação de professores, concluímos que esta traz em seu escopo a garantia de formação na jornada de trabalho, sendo quatro horas no total, se considerarmos as HTPCs e HTPPs, bem como possibilidades de avanço na carreira através da formação continuada. No entanto, a aparente inexistência de ações mais autônomas, revela um sistema que demonstra não aproveitar de maneira eficiente as possibilidades previstas.

\subsection{Representações sobre Formação Contínua}

Até o momento, procuramos revelar o contexto onde se insere o sistema, destacando sua estrutura organizacional, incluindo planos de carreira e a forma pela qual articulam seu projeto de formação contínua. Tal pano de fundo nos auxiliará na 
compreensão da manifestação de professores e gestores deste município sobre formação contínua, desvelando suas representações sobre o tema.

\subsubsection{Representação sobre Formação Contínua pelos gestores municipais}

As três entrevistas realizadas com os três gestores deste sistema de ensino trouxeram a possibilidade de identificar suas principais ações de formação no que se refere à organização de suas propostas de formação contínua.

Embora a rede conte em seu quadro com um departamento responsável por articular a formação contínua no município, a pessoa indicada pelo secretário de educação para responder em nome da secretaria pelas propostas de formação desenvolvidas foi uma das formadoras responsáveis por ministrar os cursos como o "Ler e Escrever" e o "Pnaic".

Tais entrevistas também nos permitiram avançar na compreensão das manifestações dos referidos gestores, desvelando de que forma se constituíam em representações orientadoras de palavras e ações na condução de propostas voltadas para a área.

A partir das entrevistas realizadas criamos duas categorias de análise em relação às manifestações desses gestores sobre formação contínua: 1. A formação contínua como meio de melhorar os resultados do sistema; 2. A formação contínua como responsabilidade de outrem.

No caso do Sistema A, não houve manifestações que nos levassem a considerar que os sujeitos entrevistados estabelecessem relações entre formação contínua e resultados do Sistema. Em nenhum momento foram percebidos indícios de ligação nesse sentido. A maior parte das falas dos três gestores nos conduziu a uma representação de formação como responsabilidade de outrem. É o que passaremos a expor.

\subsubsection{Formação Contínua como responsabilidade de outrem}

Diferente do observado nas manifestações de gestores dos outros Sistemas, em que a formação contínua parece constituir-se como elemento de melhoria dos resultados, os gestores do Sistema A parecem atribuir pouco sentido à formação de professores como um meio de melhorar seus índices. 
Um primeiro ponto a ser destacado quando analisamos as manifestações dos três gestores do Sistema ao se referir à formação contínua desenvolvida pelo município diz respeito ao "clima" notado durante a realização das entrevistas, dando-nos pistas para a compreensão das representações sobre o tema.

No caso da gestora municipal e da diretora de escola, que acumula também a função de coordenadora pedagógica devido ao número reduzido de alunos de sua unidade, notamos um clima que poderíamos denominar como "confortável", "conformado". Tanto a entonação como a forma como descrevem a formação parecem dizer: "estamos seguras de estar fazendo o que se deve", "estamos no caminho certo". Embora reconheçam a formação como um campo repleto de desafios, não parece haver, no caso dessas duas profissionais, nenhuma dúvida, insatisfação ou insegurança quanto ao formato adotado. A impressão que se tem é que tudo corre na mais perfeita ordem e dentro do previsto.

No discurso da gestora municipal, que descreve uma formação incompatível com o verificado, parece haver uma tentativa de "dourar a pílula", de atenuar a reflexão sobre a forma como se dá o processo. Ao declarar estar nessa função desde 2009, descreve um processo de levantamento das dificuldades que considera as reais necessidades de aprendizagem do professor como ponto de partida para as iniciativas de formação no município.

Esse processo diagnóstico visava fazer realmente uma avaliação. Não era só uma verificação de onde as crianças estavam, mas, fazendo essa avaliação, e tendo tomado essas decisões, o que as crianças não estavam atingindo. Sendo assim, observar no que os professores que estavam com dificuldade de ensinar e nesse sentido fazer uma proposta de formação pra que nós pudéssemos subsidiar esses professores. (GMSA)

No entanto, ao confrontarmos tal descrição às quase inexistentes propostas de formação cuja autoria pudesse ser atribuída à secretaria de educação (não se notando, conforme já descrito, nenhuma proposta de formação para os professores que atuam nos quartos e quintos anos do ensino fundamental), aos escassos momentos de planejamento envolvendo as equipes gestoras e a ausência de participação descrita pela coordenadora pedagógica entrevistada, as contradições evidenciam-se.

Ao mesmo tempo em que se refere ao processo diagnóstico, não articula, ainda que no discurso, uma relação entre o observado pela equipe e as ações de formação que 
desenvolve. De forma geral, notou-se na entrevista uma fala bastante evasiva, pautada em exemplos vagos e imprecisos. Ao ser perguntado sobre ações concretas relativas à formação, como registros, reflexão sobre a prática, foco das formações, formas de acompanhamento etc., seus exemplos restringiram-se às ações previstas nas determinações dos cursos repassados, no caso o "Ler e Escrever", o PNAIC e as ações de formação do projeto "Amigos do Zip". Não foi possível perceber, através dos exemplos que utiliza para descrever o "como" a rede pensa a formação, uma postura que revelasse autoria ou responsabilidade pelo processo de formação na rede municipal. Parece entender que tal responsabilidade não lhe pertence, mas sim a outras instâncias, entendendo-se como alguém que tem apenas a tarefa de fazer chegar o que foi pensado por outros, restringindo a proposta de formação da secretaria aos pressupostos defendidos pelo cursos repassados. “(...) porque a nossa proposta enquanto secretaria de educação é alfabetização e letramento."

Ao ser questionada sobre a forma como as escolas realizam devolutiva dos encontros de formação na escola, também traz um exemplo de uma das ações do curso "Ler e Escrever", desenvolvido com os coordenadores pedagógicos:

Vamos começar do "Ler e Escrever" com os coordenadores: Geralmente a gente dá, como se fosse uma "tarefinha", de uma situação-problema que eles vão ter que estar levando na escola, desenvolvendo e, no próximo encontro, socializando. Então essa devolutiva que a gente tem verificado, é nessa situação e também nas visitas pedagógicas que a fazemos. (GMSA)

No caso da diretora de escola, tal posicionamento também pode ser notado. Ao relatar o processo de formação ocorrido na rede municipal e na escola onde atua, faz referências apenas às diretivas obtidas a partir da formação com coordenadores que acontece quinzenalmente através do programa "Ler e Escrever". Assim como o notado em relação à gestora municipal, sua fala se mostrou também "conformada" quanto às ações empreendidas para o campo da formação de professores no município e na escola. No entanto, tanto sua fala como seus gestos denotam um tom aflito e inseguro diante da entrevistadora. Ao descrever as ações de formação da secretaria, fazia-o de forma breve e artificial, como alguém que fala "de fora" do processo. Seu discurso não revela uma posição autônoma diante da formação, uma vez que, ao esclarecer o formato desenvolvido na escola, também se restringe ao prescrito pelo programa. 
São as teorias, são os slides apresentados, os filmes, que são assistidos na reunião, ou uma palestra gravada com alguma especialista. Então todos os vídeos nós fomos assistindo e lá no HTPC, a gente assiste com os professores e faz uma releitura do que está acontecendo e faz uma relação com o que acontecendo na escola. Relação a partir dos textos. (GESA)

Ao ser solicitado que esclarecesse a forma como se dá a articulação dos referidos estudos com a prática de sala de aula, novamente exemplifica a partir do sugerido pelo curso. "Isso é só o que nós fizemos aqui, aí nós fazemos lá (na escola) com os professores e os professores fizeram com os alunos."

Chama atenção, ao mesmo tempo, a ausência de ações que identifiquem seus próprios anseios e convicções em relação à formação contínua, como também a falta de autonomia na condução de outras propostas de formação, ainda que constituídas a partir de diretivas do Sistema.

Ao contrário do verificado no posicionamento das duas gestoras, a coordenadora pedagógica, pareceu insatisfeita e angustiada ao falar da formação desenvolvida pelo município $^{11}$. Em sua avaliação considera insuficiente o tipo de trabalho orientado a ser desenvolvido durante os HTPCs. Segundo ela

\begin{abstract}
A rede precisava estar elaborando mesmo um programa de formação continuada. Eu acho que fica muito restrito quando você trabalha dentro da reflexão do próprio grupo, aquilo que os iguais pensam. Eu acho que fica muito dentro do igual. Não temos uma formação de pessoas, que, por exemplo, que fazem, por exemplo um mestrado, que trabalha mesmo com essa visão. (...) Eu vejo assim: há pessoas que pesquisam, que estudam, que faz a formação, por exemplo, se a gente falar, "ah eu tive contatos", "eu fui num congresso onde eu assisti a uma palestra com fulano de tal". Essa pessoa, a vida dela é um estudioso. Às vezes achamos muito teórico o que estão dizendo, mas é resultado de pesquisa mesmo, resultado de observações e você traz aquilo, você vai adequar aquilo pra sua realidade, pra dentro da sala de aula, pras dificuldades de seus alunos. (CPSA)
\end{abstract}

Como já mencionado, sua fala revela indícios de uma formação contínua de professores bastante restrita aos cursos repassados de outras instâncias pela equipe da Secretaria de Educação. Ao mesmo tempo, sua insatisfação parece não conduzi-la a novas formas de agir em relação às práticas de formação na unidade escolar onde atua, restringindo-se também ao repasse das ações do programa desenvolvido com os

\footnotetext{
${ }^{11}$ As críticas mais contundentes em relação à formação contínua desenvolvida no município foram manifestas nos momentos em que a coordenadora se encontrava sozinha com a entrevistadora.
} 
coordenadores pedagógicos do município. Sua fala revela um profissional inseguro, que se considera pouco capaz de conduzir ações inerentes a sua função.

O conjunto das diversas manifestações analisadas nos três gestores do Sistema nos conduz a uma representação de formação contínua como responsabilidade de outrem. É interessante notar que ao não serem percebidas nas propostas de formação do município, descritas através da fala dessas três gestoras, ações que incentivassem o desenvolvimento e o encorajamento da autonomia na condução de ações no interior das escolas, revela-se um contexto de representações geradoras de outras representações, formando uma espécie de círculo vicioso. Se por um lado a diretora de escola e a coordenadora pedagógica não evidenciam atitudes mais autônomas em seu lócus de atuação, por outro, não parece evidente que tais atitudes estejam sendo fomentadas por instâncias superiores, o que revelaria um contexto de representações que determinam e são determinadas.

\subsubsection{Representação de formação contínua pelos professores da rede}

Conforme já exposto, no Sistema A 62\% dos questionários enviados retornaram. Obtivemos, dessa forma, um total de 212 professores respondendo ao Survey.

A primeira seção de perguntas desse instrumento nos permitiu um levantamento aproximado do perfil dos professores da rede, lembrando que os dados relativos à situação funcional foram prestados pelos próprios professores e, conforme já mencionado, trata-se de um quadro traçado a partir de respostas de parte desses profissionais.

Do total de professores dos anos iniciais do ensino fundamental que responderam ao questionário $92 \%$ declararam ser efetivos. Dos $47 \%$ que trabalham em mais de uma escola, $87 \%$ atuam em outra unidade da rede pública. 99,5\% possuem pedagogia, sendo que, desse percentual, $38 \%$ possuem outra licenciatura.

$\mathrm{Na}$ segunda seção, as manifestações obtidas por esse instrumento foram classificadas em duas categorias, já explicitadas antes: 1 . Fatores que mais motivam a participação na formação contínua; 2. Expectativas sobre formação contínua e sua relevância para a prática. 


\subsubsection{Fatores que motivam a participação na Formação Contínua}

Com o objetivo de identificar as motivações dos professores sobre sua participação na formação contínua, procuramos abordar esse aspecto através da análise do que foi espontaneamente apontado pelos professores como motivação para a participação e através de questões diretas sobre seu posicionamento em relação à ligação entre formação contínua e valorização na carreira. Analisamos, ainda, suas repostas quanto à frequência nos cursos oferecidos e as informações sobre sua formação em nível de pós-graduação.

Apresentamos na tabela a seguir os principais fatores apontados pelos professores sobre o que motivaria sua participação em cursos de formação continuada.

\section{Tabela 3 - Fatores que mais motivam a participação nos cursos oferecidos ${ }^{12}$}

\begin{tabular}{|l|c|}
\hline Motivação para participação & ${\text { Sistema } \mathbf{A}^{\mathbf{1 3}}}$ \\
\hline Atualização/novos conhecimentos & $43 \%$ \\
\hline Aprimoramento da Prática & $24 \%$ \\
\hline Progredir na carreira/obter certificação & $12 \%$ \\
\hline Relevância/Qualidade do curso & $7 \%$ \\
\hline Socialização/ Reflexão sobre a prática & $6 \%$ \\
\hline Melhorar profissionalmente & $4 \%$ \\
\hline Não há motivação/ É obrigação & $4 \%$ \\
\hline
\end{tabular}

Um motivador que aparece destacado dentre as manifestações dos professores do Sistema é o que conduz à ideia de formar-se na busca de novos conhecimentos e atualização (43\%). Somado à ideia de melhorar profissionalmente (4\%), representam 47\% das manifestações expressas. A nosso ver, a ideia de fazer cursos em busca de atualização e novos conhecimentos, assim como a de fazer cursos para melhorar profissionalmente, pode estar ligada a diversos fatores e não nos revela, a princípio, as

\footnotetext{
${ }^{12}$ As porcentagens da tabela referem-se ao conjunto das manifestações dos professores de cada sistema pesquisado.

${ }^{13} 212$ professores e 249 manifestações
} 
reais motivações para a participação. Em outras palavras, o "não dito", expresso através do tom genérico dado ao eleger a atualização e a aquisição de novos conhecimentos, bem como melhorar profissionalmente, pode incluir outras motivações não manifestadas.

Tal raciocínio nos leva a considerar razoável que nossa análise se atenha aos fatores que apontam elementos mais concretos e que podem revelar mais claramente os motivos pelos quais os professores continuam se formando. Nesse sentido, quando os professores apontam como motivação para a participação na formação continuada a possibilidade de melhorar a prática pedagógica, de socializá-la e refletir sobre ela ou apontam ainda a relevância dos cursos ou temas tratados como critério de participação, temos, a nosso ver, um conjunto de fatores mais concretos para análise.

É possível perceber que os professores destacam os três fatores citados acima como elementos motivadores à participação. 37\% das manifestações sobre "melhoria da prática pedagógica", "socialização e reflexão sobre a prática" e "relevância dos cursos e temas tratados" indicam uma tendência pelo desejo de uma formação que dê conta das demandas do cotidiano desses professores.

Progredir na carreira, obter títulos e certificação pelos cursos é o principal motivador indicado em $12 \%$ das respostas obtidas entre os professores do Sistema A, o maior percentual dentre os três sistemas para esse fator. Observa-se, ainda, dentre as respostas dadas por esses professores, $4 \%$ das afirmações sobre a falta de qualquer motivação para a participação.

Ainda com relação à motivação para a participação em cursos, perguntamos aos professores se consideravam importante que os cursos de formação fossem contados para a progressão na carreira docente. Como era de se esperar, 100\% deles responderam afirmativamente.

Ao serem perguntados como seria sua participação caso as formações não fossem contadas para a progressão na carreira, assim se posicionaram: 
Tabela 4: Porcentagens referentes à participação caso a formação não fosse contada para a progressão funcional ${ }^{14}$

\begin{tabular}{|lrrr|c|c|c|}
\hline Se os cursos realizados não fossem & Sim & Não & Outro $^{15}$ \\
\cline { 4 - 7 } \\
contados para a carreira você & $69 \%$ & $27 \%$ & $4 \%$ \\
participaria? & & & & & \\
\hline
\end{tabular}

A ideia que liga progressões na carreira e formação confirma-se como um importante motivador para a participação nas capacitações oferecidas para os professores do Sistema A. Dentre os professores que responderam afirmativamente, três ainda complementaram, embora se tratasse de questão fechada. Enquanto uma delas declara o fato de que as formações contribuem para a prática, duas outras reforçam a ligação entre progressão e formação, sugerindo certo sentimento de desvalorização.

\footnotetext{
"acrescenta à minha prática” (1 resposta )

"os que tenho feito, não pude usar na progressão" (1 resposta)

"mas ficaria indignada, a valorização é mínima, seria mais vergonhoso ainda." (1 resposta )
}

O contexto da educação municipal parece determinar ainda mais os fatores motivacionais em relação à formação contínua oferecida. Dentre os professores que se posicionaram pela não participação, destacamos a fala de um docente.

"Creio que há um erro: os cursos oferecidos atualmente não estão atendendo às necessidades urgentes e reais dos alunos. Zoonoses e drogas não são o foco e sim alfabetização, letramento e conceitos matemáticos. Se pelo menos fossem estudos sobre Edgar Morin, Perrenoud, entre outros, tudo bem, mas fazer curso descontextualizado só para somar horas na progressão é incoerente"(1 resposta)

Parece revelar-se, no caso da professora, uma crítica quanto à forma de organização da formação continuada do Sistema, havendo, segundo ela, cursos descontextualizados com objetivo único de progressão funcional.

\footnotetext{
${ }_{15}^{14}$ As porcentagens da tabela referem-se aos 212 professores que responderam ao questionário.

${ }^{15}$ Não respondeu.
} 
Tabela 5 - Frequência de participação manifesta pelos professores do Sistema $\mathrm{A}^{16}$

\begin{tabular}{|l|c|c|}
\hline Com que frequência você participa dos & Sempre & Às vezes \\
\cline { 2 - 3 } $\begin{array}{l}\text { cursos de formação oferecidos pelo } \\
\text { município? }\end{array}$ & $\mathbf{4 8 \%}$ & $\mathbf{5 0 \%}$ \\
\hline
\end{tabular}

A metade dos professores afirma participar "às vezes" dos cursos de formação, mesmo sendo estes contados para progressão na carreira. Daqueles que afirmam participar "sempre", destacam-se manifestações significativas sobre a inexistência de cursos. A essa questão fechada, acrescentaram:

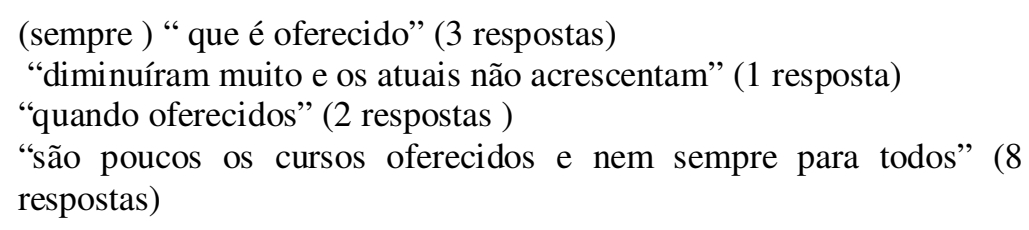

A relação entre formação e carreira nos três Sistemas é, em parte, também revelada pelos dados manifestos sobre a formação em nível de pós-graduação.

Tabelas 6 - Percentuais de formação em nível de pós-graduação manifestos pelos professores

\begin{tabular}{|c|c|}
\hline Possui curso de pós-graduação? & Sistema A \\
\hline Lato Sensu & $\mathbf{8 3 , 5 \%}$ \\
\hline $\begin{array}{c}\text { Stricto Sensu } \\
\text { (mestrado) }\end{array}$ & $\mathbf{0 , 5 \%}$ \\
\hline Total & $84 \%$ \\
\hline
\end{tabular}

Conforme já observado, o Sistema oferece benefícios para aqueles que realizam cursos de pós-graduação lato-sensu. A tabela acima mostra um percentual significativo

\footnotetext{
${ }^{16}$ As porcentagens da tabela referem-se aos 212 professores que responderam ao questionário.
} 
de professores com tal titulação, fortalecendo a ideia de que os incentivos podem estar influenciando o interesse dos professores pela realização de cursos de pós-graduação.

No Sistema A, 37\% das motivações manifestas apontam mais concretamente para questões pedagógicas, sendo que o maior índice de respostas de professores que se motivam pelos benefícios na carreira também é ali verificado (12\%), além de ser o único sistema no qual se apontou "nenhuma motivação para participar”(4\%).

É significativo também o número de professores que afirmaram não participar caso a formação não fosse contada para a progressão (27\%). Mesmo havendo incentivo na carreira aos que frequentam as capacitações oferecidas pelo sistema municipal de ensino, apenas $48 \%$ afirmam participar sempre. Se considerarmos as declarações dos professores quanto à escassez de propostas e qualidade da formação oferecida, vemos fortalecida nossa hipótese sobre a fragilidade do Sistema na consecução de seus programas de formação. Ao mesmo tempo em que a legislação voltada para a educação municipal e a organização da jornada cria tais espaços, estes não se consolidam.

\subsubsection{Expectativas sobre a Formação Contínua e sua relevância para a prática}

As questões que compuseram esta categoria de análise tinham como objetivo desvelar representações sobre formação contínua, considerando a manifestação dos professores em relação às suas expectativas quanto ao formato de cursos, áreas do conteúdo a serem contempladas e relevância desses cursos de formação para a prática pedagógica. Também como uma forma de conhecer as expectativas de formação contínua, solicitamos que avaliassem os cursos oferecidos a partir de questionamentos em relação à articulação entre teoria e prática.

A primeira questão dessa categoria de análise focava a avaliação que os professores fazem dos cursos de formação oferecidos, tendo três alternativas como opção: 1. São muito teóricos e não se relacionam com a realidade da escola; 2. Apresentam apenas receitas prontas, sem explicar o porquê das coisas; 3 . Outras.

A maioria dos professores que responderam ao questionário tende a considerar os cursos oferecidos muito teóricos. Conforme apuramos, 66\% optaram por esta alternativa. Por outro, há aqueles que parecem entender faltar fundamentação teórica aos cursos, uma vez que $8 \%$ optaram por classificá-los apenas como transmissão de receitas prontas. Dos 3\% que estabelecem outras críticas, fazem-no a partir de outras justificativas. Para estes, os cursos oferecidos “Apresentam experiências inexequíveis", 
"Não apresentam receitas, falam que sua prática é errada", "Falta prática, ludicidade", "São muito repetitivos", "Não são inovadores".

Já $22 \%$ dos professores parecem avaliar positivamente os cursos oferecidos a partir do que enxergam de contribuição a sua prática pedagógica. Enquanto $11 \%$ assinalam positiva a articulação entre teoria e prática, $2 \%$ apontam contribuições "apesar" da teoria.

Do total de professores que responderam ao questionário, $8 \%$ não responderam à questão e $4 \%$ não se posicionaram claramente em relação à pergunta.

Procurando desvelar a relação que estabelecem entre o formato dos cursos oferecidos e sua contribuição para a produção de novos conhecimentos pedagógicos, solicitamos aos professores que apontassem espontaneamente qual o formato de curso consideram mais apropriado para a formação contínua.

Dentre as 220 declarações sobre a preferência em relação ao formato de curso mais adequado na visão dos professores do Sistema A, 35\% apontam em direção ao enfoque teórico ou prático dado pelos cursos. Merecem destaque as declarações que são enfáticas em preferir cursos com pouca teoria, como é o caso de $18 \%$ das declarações que sinalizam uma preferência para "cursos práticos com pouca teoria" e para cursos "com troca de experiência" (3\%). Esses últimos explicam que cursos com troca de experiência são ideais porque "deixa de ser teoria" e porque "deixa de ser teoria e sim o real".

Há professores que parecem se manifestar em relação ao formato mais adequado de cursos a partir de um enfoque de ordem prática. A escolha por determinado formato de curso se dá considerando aqueles que melhor se encaixam ao cotidiano dos professores e que não comprometem o tempo de descanso desses profissionais. Dessa forma, 31\% das declarações apontam para uma preferência por cursos à distância (22\%), em horário de trabalho (7\%), semanal ou quinzenal (2\%). Dentre as justificativas para a escolha desse formato destacam-se, a título de exemplo: "flexibilidade de horário", "professores dobram período e não têm tempo", "sem prazos rígidos, pois o professor precisa estudar conforme sua rotina", dentre outras.

Há também aqueles que parecem fazer suas escolhas a partir de justificativas que enfatizam o aproveitamento do curso e suas possibilidades de aprendizagem por parte do professor. Os $18 \%$ que apontaram como melhores os formatos presencial $(12 \%)$ e semipresencial (6\%) levantam questões como maiores possibilidades de troca de experiência, resolução de dúvidas, maior participação e presença do formador. Os 
professores que apontaram como ideal os cursos de 180h (10\%) focaram, em sua maioria, a existência de maiores possibilidades de discussão e aprofundamento, muito embora uma das justificativas apontadas sinalize para a possibilidade de progressão funcional que cursos com essa carga horária oferecem.

Houve, ainda, 6\% dos professores que se manifestaram favoravelmente em relação a existência de "cursos lúdicos", aqueles que contemplam "o professor com papel ativo", cursos semelhantes ao "PNAIC" e de "participação facultativa". Não houve, no caso desses professores, nenhuma razão apontada para tais escolhas. Perguntamos também aos professores quais os temas que consideravam importantes serem abordados nos cursos de formação contínua e obtivemos os seguintes dados:

\section{Quadro 7: Principais temas/áreas apontadas para a abordagem na} formação contínua

\begin{tabular}{|c|c|}
\hline Tema/área & Percentual de respostas $^{17}$ \\
\hline Alfabetização e Letramento & $20 \%$ \\
\hline Metodologias de ensino & $22 \%$ \\
\hline Matemática & $14 \%$ \\
\hline Inclusão/Dificuldade de aprendizagem & $13 \%$ \\
\hline Língua portuguesa & $10 \%$ \\
\hline Outras áreas do conhecimento & $7 \%$ \\
\hline Voltados para a realidade & $7 \%$ \\
\hline Todas as áreas do conhecimento & $4 \%$ \\
\hline Gestão & $2 \%$ \\
\hline Temas transversais & $1 \%$ \\
\hline
\end{tabular}

Dos dados acima, destacamos a preferência dos professores pelas áreas ligadas ao estudo da língua. Está claro para nós a existência das tradicionais dificuldades apontadas pelos professores com relação ao ensino da língua, especialmente nos anos iniciais. Ainda assim, chama-nos a atenção o fato de $30 \%$ entenderem ser necessário focar esta área do currículo, e, dentre esses, $20 \%$ apontarem como mais importante a abordagem nas áreas de alfabetização e letramento. Embora se observe um significativo percentual que aponta para cursos voltados para a metodologia, nota-se certo

17313 declarações, sendo que houve professores que apontaram mais de uma área. 
desequilíbrio entre o apontado para outras áreas do conhecimento. Sobre isso, cabe questionar: Estariam os ( poucos ) cursos veiculados pela secretaria de educação e destacados, especialmente pela gestora municipal como foco do trabalho de formação no município, determinando as representações sobre as demandas de formação contínua desses professores?

Sobre a relevância da formação para o enfrentamento dos desafios pedagógicos enfrentados pelos professores, uma maioria significativa considera determinante o trabalho que se faz individual ou coletivamente na escola. É o que se pode observar na tabela abaixo.

Tabela 7: Relevância da formação contínua para o enfrentamento dos desafios pedagógicos

\begin{tabular}{|c|c|c|c|}
\hline $\begin{array}{c}\text { O trabalho } \\
\text { individual e } \\
\text { coletivo da escola } \\
\end{array}$ & $\begin{array}{c}\text { A ajuda externa } \\
\text { possibilitada } \\
\text { pelos cursos } \\
\end{array}$ & \multicolumn{2}{|l|}{ Outra } \\
\hline \multirow{9}{*}{$77 \%$} & \multirow[t]{9}{*}{ 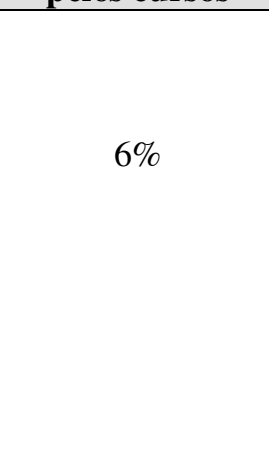 } & Os dois & $9 \%$ \\
\hline & & Não respondeu & $3 \%$ \\
\hline & & $\begin{array}{c}\text { A troca entre os pares, o trabalho em } \\
\text { equipe }\end{array}$ & $2 \%$ \\
\hline & & Reconhecer que é preciso atualizar-se & $0,4 \%$ \\
\hline & & $\begin{array}{l}\text { A estrutura para que se coloque em } \\
\text { prática o estudado }\end{array}$ & $0,4 \%$ \\
\hline & & Prática aliada à teoria & $0,4 \%$ \\
\hline & & Auxílio de especialistas & $0,4 \%$ \\
\hline & & Valorização & $0,4 \%$ \\
\hline & & Apoio da equipe & $0,4 \%$ \\
\hline
\end{tabular}

Nota-se que é apenas de $9 \%$ o percentual de professores que consideram relevantes a articulação dos dois fatores, sendo um número muito reduzido de professores que atribuem exclusivamente aos cursos maior relevância para o enfrentamento dos desafios pedagógicos. Tal posicionamento dos professores parece fortalecer a ideia da necessidade de cursos de contemplem as reais necessidades das unidades escolares, fortalecendo-as como lócus privilegiado de formação.

Nesse mesmo sentido, ao tentarmos articular a ideia de aquisição de conhecimentos baseados na prática educativa aliada aos cursos de formação, também perguntamos aos professores a quais fatores atribuíam seus atuais conhecimentos pedagógicos. Como se poderá observar na tabela abaixo, foi baixo (4\%) o percentual de professores que atribuíram seus conhecimentos pedagógicos unicamente ao curso de graduação realizado. 
Tabela 8: Principais contribuições à construção de conhecimento pedagógico

\begin{tabular}{|c|c|c|}
\hline $\begin{array}{c}\text { À minha prática e aos } \\
\text { cursos realizados }\end{array}$ & Ao meu curso de graduação & As duas opções \\
\hline $88 \%$ & $4 \%$ & $8 \%$ \\
\hline
\end{tabular}

Mesmo havendo 8\% que considerem como determinantes tanto o curso de graduação quanto os cursos realizados aliados à prática, o percentual que exclui os cursos de graduação é muito significativo (88\%). Houve ainda três professores que acrescentaram comentários para além da questão, atribuindo também os conhecimentos pedagógicos: "Aos meus estudos particulares", aos "cursos de Educação a distância" e a "troca de experiência e pesquisa".

O conjunto de elementos obtidos a partir da análise das manifestações em relação à expectativa dos professores quanto aos cursos oferecidos, bem como sua relevância para a prática pedagógica, evidencia uma tendência em avaliar negativamente os cursos oferecidos pelo sistema de ensino, já que 77\% atribuem crítica à forma pela qual o sistema articula a relação teoria e prática Nota-se, a partir dos dados expostos que parte significativa desses professores parece fazê-lo por não enxergar contribuições para sua prática pedagógica, atribuindo pouca relevância à ajuda externa possibilitada pelos cursos $(6 \%)$. Tal hipótese se fortalece ao notarmos que muitos professores parecem estar escolhendo seus cursos a partir de sua viabilidade prática, notando-se $31 \%$ dos professores que responderam ao questionário dizendo ser este o critério de escolha dos cursos.

Ao mesmo tempo em que é possível perceber anseios por uma formação que dê conta da realidade, é notório o percentual de professores que preferem cursos cujos temas já estejam sendo priorizados pelo sistema de ensino, sendo que 30\% mostram preferir cursos para a área de língua portuguesa, especialmente alfabetização e letramento. 


\subsection{A falta de autonomia na condução das ações de formação contínua e o foco nas vantagens profissionais}

Com o objetivo de desvelar as representações de professores e gestores do Sistema A, investigamos o cenário no qual se inserem os sujeitos envolvidos na pesquisa.

Dessa forma, a análise do contexto de formação trouxe-nos possibilidades de compreender melhor o cenário, entendendo-o como um nível de compreensão a ser confrontado às manifestações dos sujeitos, estabelecendo relações entre os diversos aspectos da realidade observada.

Conforme sugerido na análise tecida, verificamos que a confrontação entre os diversos elementos que compõem e contexto e as representações sobre formação contínua de gestores e professores possibilita-nos concluir a existência de um Sistema envolto numa espécie de círculo vicioso no que se refere à capacitação profissional.

Observamos que, no Sistema A, a legislação educacional oferece bons espaços de formação, com horas de estudo coletivo garantidas na jornada de trabalho e possibilidades de progredir na carreira, por meio da entrega de títulos, dentre outros benefícios já citados. Tal cenário de incentivos nos revelou um corpo docente qualificado, no qual $84 \%$ dos professores que responderam ao questionário possuem pós-graduação.

Contraditoriamente, a análise das propostas de formação desenvolvidas no município aponta para a ausência de iniciativas de autoria do Sistema que se restringe ao repasse de dois cursos, um do governo federal e um do governo estadual. Além disso, ainda que se registrasse a existência de encontros periódicos entre os coordenadores pedagógicos da rede, estes se constituem na transmissão de um dos dois cursos repassados, o "Ler e Escrever", também oferecido aos professores pelos coordenadores.

Dessa forma, o que se infere é que tal forma de agir e pensar os programas de formação em âmbito municipal não tem fomentado suporte técnico e encorajamento necessário para que os gestores (diretores e coordenadores) escolares possam se lançar em propostas de formação mais inovadoras, o que nos levou a atribuir-lhes uma representação sobre formação contínua como responsabilidade de outrem.

É nesse contexto que se desvelam representações de professores que pouco percebem relevância da formação oferecida pelo município para sua prática pedagógica, 
tendendo a representar a formação contínua como um meio de progredir na carreira. Ao mesmo tempo, é notória a quantidade de manifestações observadas que avaliam negativamente a capacitação profissional oferecida, manifestando anseios por uma formação voltada para a prática e que forneça subsídios para a produção de conhecimento pedagógico que dê conta da realidade vivida.

É possível perceber, como já dito, que contexto municipal e representações interagem e moldam um ao outro, num movimento que parece indicar a existência de um círculo vicioso, uma vez que nele se verificam, ao mesmo tempo, gestores com tendência a se responsabilizar pouco pelas inovações no campo da formação contínua e a não considerá-la importante para a obtenção de melhores resultados no sistema e professores que, embora reconheçam a necessidade de que a formação se volte para a resolução dos desafios pedagógicos, tendem a atrelar de maneira bastante significativa formação e vantagens na carreira.

Diante do cenário apresentado, ainda deixaríamos o seguinte questionamento: Seria o conjunto de problemáticas apresentadas em relação à formação contínua, incluindo as representações de gestores e professores, os fatores que estariam determinando o desempenho de aprendizagem verificado nos índices obtidos pelo sistema municipal?

Ainda que se reconheça a necessidade de estudar de maneira mais profunda todas as outras possíveis causas do baixo desempenho dos alunos, entendemos ser necessário compreender a realidade posta superando as representações que ora se objetivam entre gestores e professores. 


\section{O SISTEMA B}

\subsection{Contexto sócio-econômico, Estrutura da Secretaria de Educação e Plano de}

Carreira

A cidade à qual pertence o sistema $\mathrm{B}$ está situada a 443 quilômetros da capital paulista, no centro-oeste, e é considerada uma das mais populosas do interior. Com forte potencial econômico, a cidade possui diversas faculdades e universidades públicas e particulares, atraindo estudantes de diversas cidades e regiões do país.

Suas atividades econômicas recaem principalmente sobre o setor industrial. Além de diversas empresas que atuam no setor têxtil, metalúrgico e de construção, destaca-se especialmente o segmento voltado para a produção de alimentos, abrigando empresas de grande porte no setor. A seguir, expõem-se os principais indicadores sócioeconômicos da cidade.

Tabela 9: Dados sócio-econômicos do município

\begin{tabular}{|c|c|c|c|c|c|}
\hline População & $\begin{array}{c}\text { Receita do } \\
\text { Município }\end{array}$ & $\begin{array}{c}\text { Renda per } \\
\text { Capita }\end{array}$ & IDHM & $\begin{array}{c}\text { IDHM } \\
\text { Educação }\end{array}$ & $\begin{array}{c}\text { Taxa de } \\
\text { Analfabetismo }\end{array}$ \\
\hline 221.378 & 559.461 .067 & 794,23 & 0,798 & 0,776 & 4,06 \\
\hline
\end{tabular}

Fonte: Fundação Seade. Consulta em 19/03/2014.

Há diversas faculdades públicas e privadas na cidade, havendo, dentre as públicas, uma que oferece cursos na área da educação. Destacam-se, principalmente, os cursos na área de Ciências Sociais, Negócios e Direito, que detêm o maior número de matrículas, seguidos dos cursos voltados à área da saúde e bem-estar social. As matrículas na área da educação cresceram nos últimos anos, mas ainda são muito inferiores, se comparadas aos cursos citados.

$\mathrm{Na}$ educação básica, o ensino médio e os quatro últimos anos do ensino fundamental estão sob responsabilidade da rede estadual de ensino, ficando a cargo do município os segmentos de educação infantil e os anos iniciais do ensino fundamental.

O gráfico a seguir apresenta o movimento das matrículas dos segmentos pertencentes à rede municipal de ensino entre os anos de 1999 a 2013. 
Gráfico 4: Movimento das matrículas na rede municipal de 1999 a 2013
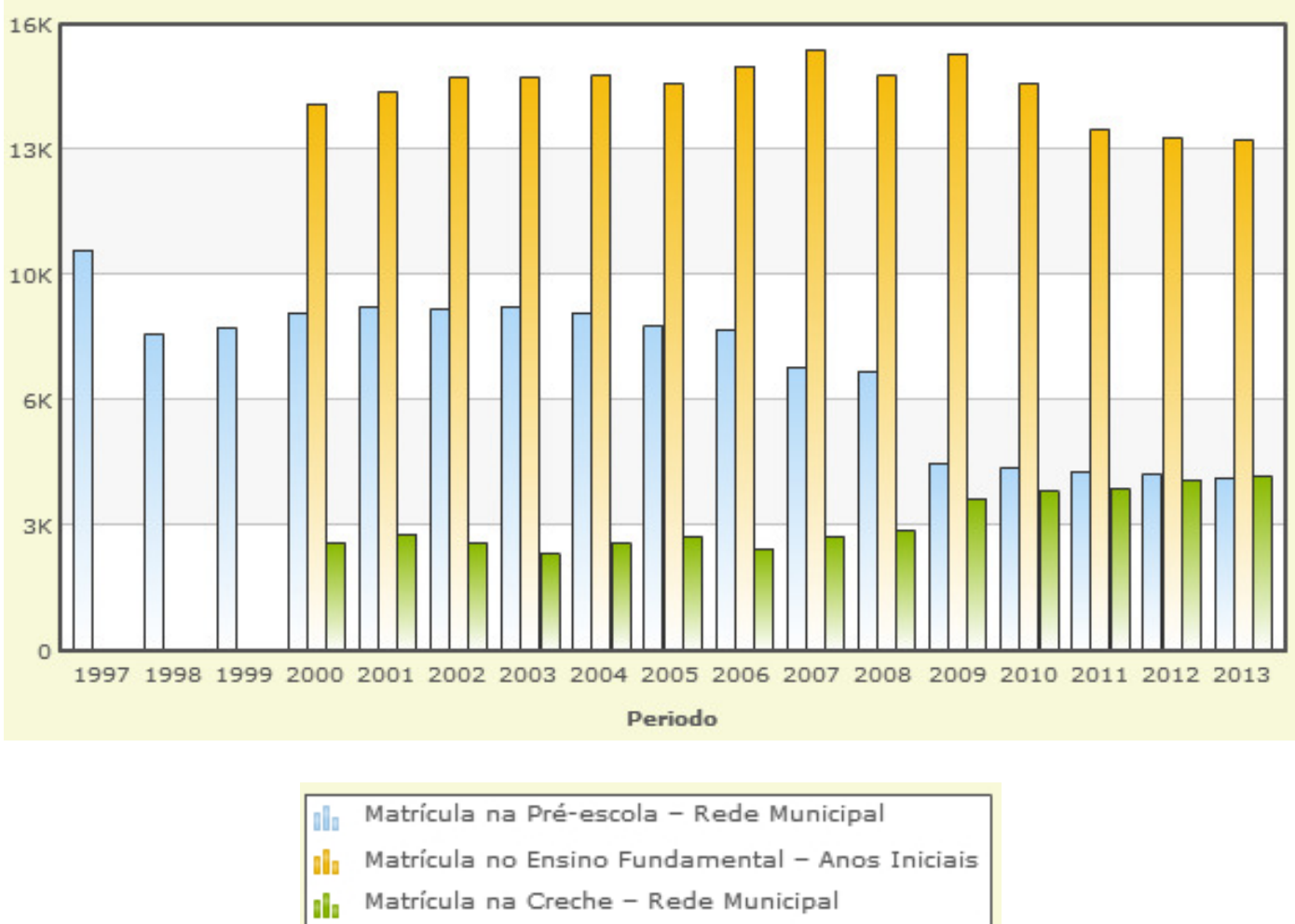

Fonte: Seade

Os dados expostos no gráfico mostram o aumento de responsabilidades do município quando, a partir do ano 2000, tem em sua rede os alunos da primeira etapa do ensino fundamental, devido à municipalização do ensino. Nota-se, ainda, que, no mesmo ano, a exemplo dos demais municípios brasileiros, passa a atender o segmento creche como uma etapa de ensino da educação básica, já que, até a promulgação da atual LDB, esse setor pertencia à assistência social. É possível perceber também uma diminuição das matrículas na etapa de pré-escola, que se observa a partir de 2008, principalmente, devido à implantação do ensino fundamental de nove anos. O Sistema registrou, segundo o censo escolar de 2013, um total de 16.461 alunos, sendo 4.414 na pré-escola, 7.579 na primeira etapa do ensino fundamental e 4.468 matriculados na etapa creche.

Quanto ao desempenho dos alunos do Sistema nas avaliações externas, apresentamos os resultados obtidos a partir da aplicação da Prova Brasil. O quadro abaixo mostra a evolução dos índices do IDEB no sistema municipal. 


\section{Quadro 8 - Resultado do IDEB - Sistema B}

\begin{tabular}{|c|c|c|c|c|c|c|c|c|c|c|c|c|}
\hline \multicolumn{5}{|c|}{ Ideb Observado } & \multicolumn{8}{|c|}{ Metas Projetadas } \\
\hline $\begin{array}{c}2005 \\
=\end{array}$ & $\begin{array}{c}2007 \\
*\end{array}$ & $\begin{array}{c}2009 \\
*\end{array}$ & $\begin{array}{c}2011 \\
*\end{array}$ & $\begin{array}{c}2013 \\
*\end{array}$ & $\begin{array}{c}2007 \\
=\end{array}$ & $\begin{array}{c}2009 \\
=\end{array}$ & $\begin{array}{c}2011 \\
*\end{array}$ & $\begin{array}{c}2013 \\
*\end{array}$ & $\begin{array}{c}2015 \\
*\end{array}$ & $\begin{array}{c}2017 \\
\quad\end{array}$ & $\begin{array}{c}2019 \\
*\end{array}$ & $\begin{array}{c}2021 \\
*\end{array}$ \\
\hline 5.4 & 5.6 & 6.4 & 6.4 & 6.5 & 5.4 & 5.7 & 6.1 & 6.3 & 6.6 & 6.8 & 7.0 & 7.2 \\
\hline
\end{tabular}

Fonte: Inep

Dentre os Sistemas pesquisados é o que apresenta o maior índice, avançando mais de um ponto em relação ao primeiro ano de aplicação da prova, 2005, crescendo de 5,4 para 6,5 no ano de 2013. O Sistema supera a média das escolas municipais em nível nacional, que é de 4,9, e a média das demais escolas brasileiras que atendem ao mesmo segmento, que é de 5,2. Além disso, mantém um crescimento sustentável ao longo dos anos e dentre as dezoito escolas avaliadas em 2013, apenas seis não atingem a meta projetada para a unidade.

No que se refere ao aprendizado da língua, especialmente na competência leitora e interpretação de textos, $61 \%$ das crianças têm, segundo avaliação de 2013, um aprendizado adequado, dois pontos a mais que a avaliação de 2011. No entanto, o percentual de alunos com aprendizado insuficiente vem crescendo nas últimas avaliações, passando de $8 \%$, em 2009, para 12\% em 2013. A maior nota observada entre as escolas é de $89 \%$, e a menor, de $46 \%$ com aprendizado adequado.

Em relação ao aprendizado na área de matemática, o desempenho médio é maior que o observado em português, ou seja, 66\% dos alunos apresentam desempenho adequado nas habilidades que envolvem resolução de problemas. Ocorre que o desempenho para o nível adequado de aprendizagem vem caindo ao longo das três últimas avaliações, já que em 2009 esse percentual era de 71\%, cinco pontos a mais que o verificado na avaliação de 2013. Além disso, é preciso ressaltar que o número de alunos com aprendizado insuficiente vem aumentando, subindo de 7\%, em 2009, para $12 \%$ em 2013.

Compreender como está organizado o Sistema B não é tarefa fácil quando se deseja fazer isso através da lei que rege o Estatuto do Magistério Público Municipal. Trata-se da Lei 3200 de 30/12/86, que se encontra fragmentada e desatualizada do ponto de vista do amparo legal que se deseja para um quadro de magistério desse porte, tendo 
passado por inúmeras emendas ao longo dos anos. Constam quase 150 modificações, alterações e acréscimos.

O referido Estatuto traz a seguinte organização do quadro do magistério, a saber:

I - Corpo docente: Professor de EMEI ${ }^{18}$, Professor de Educação Especial,

Professor de $\operatorname{EMEF}^{19}\left(1^{\mathrm{a}}\right.$ a $4^{\mathrm{a}}$ série) e Professor de Libras.

II - Corpo Dirigente: Diretor de EMEI, Auxiliar de Direção de EMEI, Diretor de

EMEF e Diretor de Escola Municipal ${ }^{20}$.

III - Especialistas em Educação (Grupo de Apoio Técnico): Assistente Técnico

de Área de EMEI, Assistente Técnico de Área de EMEF, Assistente Técnico de Área de Educação Especial, Assistente Técnico de Área de Entidades Assistenciais Conveniadas, Professor Coordenador de EMEI, Professor Coordenador de EMEF, Diretor de Gestão Administrativa, Assessor de Gestão Estratégica, Coordenador Administrativo de Alimentação Escolar, Diretor de Gestão Escolar, Assessor Especial de Políticas Educacionais, Supervisor da Educação Básica, Coordenador de Gestão Escolar e Coordenador de Comunicação Social.

\section{IV- Secretário Municipal da Educação.}

A lei não descreve as atribuições de cada um dos cargos, tampouco a sua forma de provimento. A partir de alguns indícios, chegamos à conclusão de que os cargos do corpo docente e do corpo dirigente são providos por concurso, pois detectamos editais de concursos promovidos pela prefeitura que abrangiam esses cargos. Já os cargos de Auxiliar de Direção de EMEI, Auxiliar de Direção de EMEF, Assistente Técnico de Área - EMEI, Assistente Técnico de EMEF, Coordenador de EMEI, Assistente Técnico de Área de Educação Especial e Assistente Técnico de Área de Entidades Assistenciais Conveniadas são cargos oriundos da própria rede de ensino, já que um dos requisitos para seu preenchimento é ser professor da rede de ensino há no mínimo três anos.

O Capítulo que trata dos direitos e deveres é o único conjunto de normas explícitas a que estão sujeitos os membros do quadro do magistério. Não há menção aos

\footnotetext{
${ }^{18}$ Escola Municipal de Educação Infantil

${ }^{19}$ Escola Municipal de Ensino Fundamental

${ }^{20}$ Trata-se do único cargo que permanece, já que os cargos de Diretor de EMEI e Diretor de EMEF serão extintos após sua vacância.
} 
processos de formação continuada, tampouco sobre a quem é atribuída a função de realizá-la.

A secretaria de educação, na tentativa de colocar em prática seu projeto de educação frente a uma legislação caduca, arrisca um trabalho pautado na informalidade legal. De qualquer sorte, elegemos como parâmetro da análise do quadro da secretaria de educação o organograma fornecido pela atual secretária de educação, que traduz o funcionamento prático através dos cargos disponíveis, o que, segundo informações, atende informalmente pela nomenclatura descrita na figura abaixo.

Figura 1 - Organograma atual da Secretaria de Educação - Sistema B

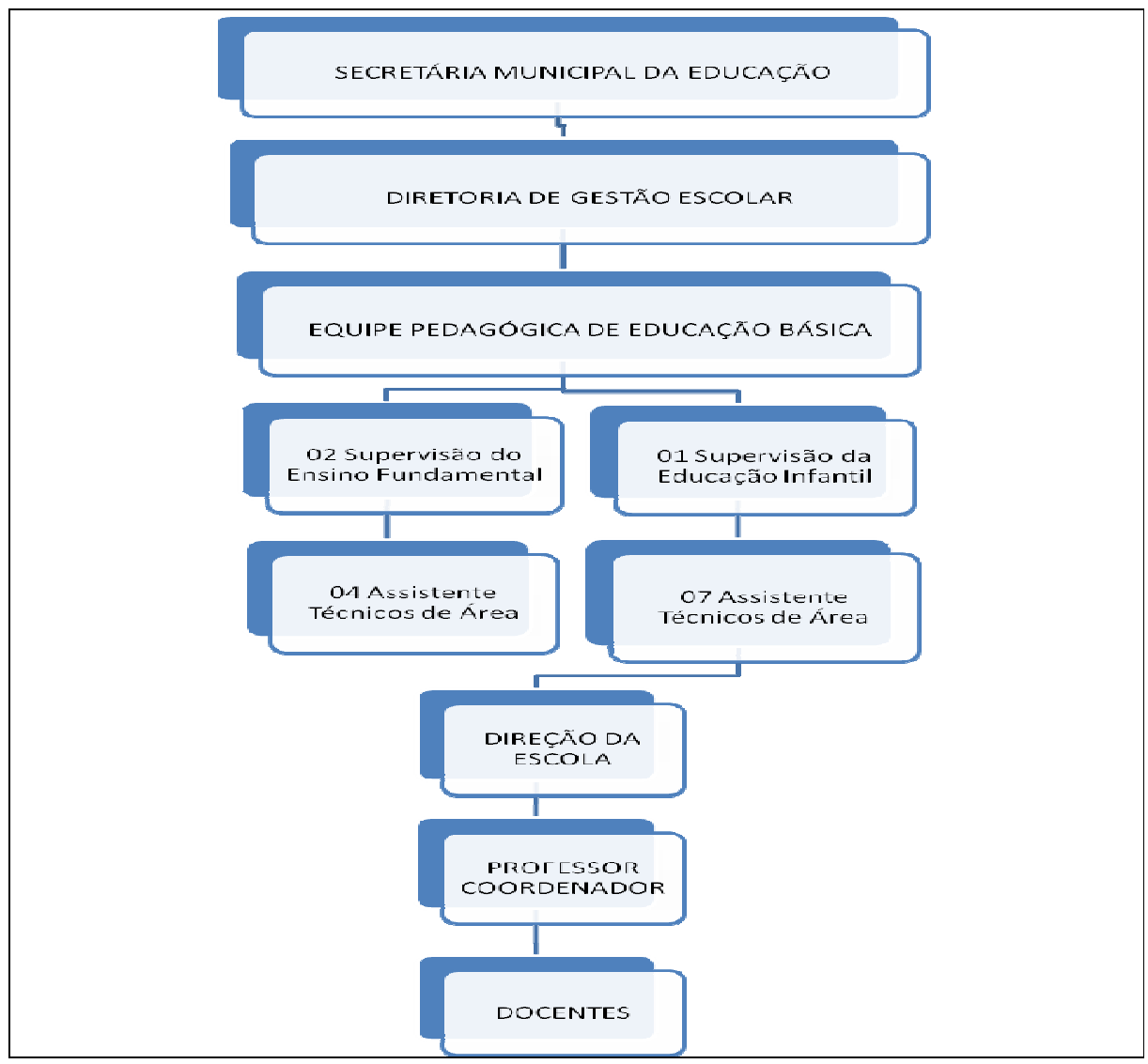

Fonte: Secretaria de Educação.

A jornada dos professores do Sistema B está assim organizada: 


\section{Quadro 09 - Programas de Formação Contínua previstos na jornada semanal de trabalho dos professores do Sistema B}

\begin{tabular}{|c|c|c|}
\hline Contemplados & Jornada com alunos & $\begin{array}{c}\text { Horas de Estudo em } \\
\text { Conjunto - HEC }\end{array}$ \\
\hline Professor de EMEI & 20 horas & - \\
\hline Professor de EMEF & 25 horas & 2 \\
\hline Professor de Educação & 20 horas & - \\
\hline Especial & & \\
\hline
\end{tabular}

Fonte: Plano de Carreira do Município.

Apenas os professores que atuam em escolas de ensino fundamental possuem em sua jornada duas horas de estudo por semana, sendo que o tempo dedicado ao trabalho pelos professores de Educação Infantil e Educação Especial não prevê nenhuma possibilidade de articulação pelo trabalho coletivo.

Não identificamos no Estatuto do Magistério do Sistema B nenhum tipo de incentivo à formação, como as progressões via acadêmica e não acadêmica observadas no sistema A, como também nenhum outro documento que contivesse normas ou diretrizes sobre o assunto. Nesse sentindo, identificamos a existência de normatizações relacionadas ao currículo do município. Trata-se da sua proposta curricular, elaborada para os três níveis de atendimento: berçário, educação infantil e ensino fundamental. O documento é composto, nas três etapas de ensino, pelas expectativas de aprendizagem, pelos conteúdos a serem contemplados e pelas orientações didáticas. No ensino fundamental, essa organização está voltada para as áreas do conhecimento desse segmento, divididos nas cinco séries, $1^{\circ}$ ao $5^{\circ}$ ano, sendo que o mesmo ocorre nas demais etapas, ou seja, há um tratamento específico para os conteúdos e faixa etária de cada um deles.

\subsection{A proposta de formação do Sistema $B$}

O cronograma de formação oferecido por esta secretaria de educação, assim como os dados obtidos através das entrevistas realizadas com gestores deste sistema, 
revelam uma grande preocupação e vontade de formar melhor seus professores e oferecer-lhes subsídios para atuarem em sala de aula.

Há uma gama bastante variada de propostas de formação no que concerne à quantidade de cursos e oficinas, como também à carga horária e ao público-alvo contemplado. São mais de cinquenta propostas de formação desenvolvidas nos dois anos analisados, voltadas para todos os segmentos dos profissionais que atuam na rede. Para os professores do ensino fundamental, destacam-se as propostas de cursos voltados para as áreas de leitura e escrita e matemática, que predominam dentre os cursos oferecidos para os professores desse segmento. Aos professores que atuam na educação infantil, os temas permeiam a especificidade da área. Há também cursos voltados para a área de gestão, o que inclui reuniões semanais, grupos de estudo e cursos de longa duração, como é o caso do curso "Escola de Gestores".

Os cursos, palestras, seminários e oficinas são desenvolvidos principalmente pela equipe técnica da secretaria de educação, com participação de professores de universidade pública local, além de assessorias contratadas, o que representa uma pequena parcela dentre os realizadores dos cursos.

As entrevistas realizadas confirmam a ampla oferta de cursos. A gestora municipal, indicada pela secretaria como responsável para falar sobre tais propostas, declarou que as formações são planejadas com base no levantamento feito pela secretaria de educação a partir das necessidades observadas na rede de ensino, através de reunião com os coordenadores que, após consulta aos professores, elegem os principais temas.

A gestora municipal, como as demais gestoras escolares entrevistadas, aponta também a avaliação externa realizada pela secretaria de educação como um indicador das necessidades da rede, que revelariam as maiores dificuldades apresentadas pelas crianças matriculadas no ensino fundamental.

Das mais de cinquenta propostas de formação desenvolvidas pela secretaria de educação, voltadas para o ensino fundamental, conclui-se que muitas delas acontecem nos horários de $\mathrm{HEC}^{21}$, sendo realizadas na própria escola, semanalmente, ou na sede da secretaria, conforme cronograma organizado pela equipe técnica.

Conforme já apontado, somente os professores de ensino fundamental são contemplados com horas de estudo na jornada de trabalho. Os HECs compreendem duas

\footnotetext{
${ }^{21}$ Horário de Estudos Coletivos
} 
horas semanais de estudo e são realizados na escola pelos coordenadores pedagógicos, que recebem da secretaria de educação orientações quinzenais para o direcionamento desses momentos em cada unidade. No entanto, como apontam os três entrevistados, tais proposições são bastante flexíveis, não havendo obrigatoriedade de aplicação nos moldes indicados, ficando os gestores escolares livres para o desenvolvimento de outras propostas que julgarem viáveis.

Quando eles percebem que há necessidade de que aquele assunto que foi discutido aqui na secretaria seja de interesse para os professores naquele momento eles já passam as informações, o curso e atendem a necessidade. Caso contrário, não. Os coordenadores têm a liberdade de observar a realidade da escola dele e fazer o planejamento de acordo com a sua realidade. (GMSB)

Fica evidente na fala dos entrevistados a autonomia dada pela secretaria de educação para que cada escola desenvolva a formação conforme a necessidade percebida por ela. É o que se pode inferir a partir da fala da diretora de escola, no trecho a seguir.

(...) dificilmente coincide de que o que está sendo estudado aqui seja o que está sendo estudado lá. Somos muito "pé no chão", avaliamos a nossa escola o tempo inteiro. Eu estou falando da minha realidade. (...) Tem escola que abraça com as duas mãos e leva. (...) a secretaria não faz o meu momento lá. Esse momento é nosso, próprio. Nós temos lá a nossa sequência. (GESB)

Ao ser questionada sobre a aplicação das propostas da secretaria pelos coordenadores, a gestora municipal declarou haver grande adesão por significativa parte deles, embora não haja uma quantificação a esse respeito.

A secretaria disponibiliza o material de estudo utilizado durante os encontros quinzenais, que se constitui basicamente de textos, slides, vídeos e, em alguns casos, sugestões de atividades práticas. Mesmo havendo ampla oferta de material e encontros, não foi possível perceber a existência de direcionamentos quanto às formas de organização de estudos, o que a nosso ver revela uma tendência bastante aberta no que diz respeito à estruturação desses momentos nas escolas, bem como sobre a forma de articulação entre estudo e prática de sala de aula.

As formas de avaliação da formação desenvolvida na rede também não seguem critérios únicos. As formações que acontecem na escola são acompanhadas pela secretaria de educação mediante relatório mensal, elaborado por escrito e enviado pelos 
coordenadores das escolas sobre o que foi realizado em cada unidade. Quanto às outras propostas, são abertas e bastante focadas no curso, ficando a critério do aplicador a forma de avaliar.

Não, é livre. Além dos documentos que os orientadores vão oferecendo, ele também tem a sua anotação. Já nos HECs, nas formações que nós oferecemos na secretaria, é através do relatório do HEC mesmo. Como os professores do primeiro ano, eles enviam uma avaliação bimestral pra nós. De como foram, inclusive, as discussões dos HECs e também do curso de formação que eles têm. Agora os demais professores, não. É sempre no final do curso, durante o curso. Aí vai depender de quem está organizando o curso. Posso exemplificar: eu ministrei curso no primeiro semestre. Então, ao final do dia, eu já conversei com os professores e perguntei, promovi com eles uma discussão sobre a possibilidade de aplicação daquelas atividades. No mesmo momento, foi oralmente. No caso de outra professora, ela propõe que os professores apliquem na sala e depois traga o resultado dos alunos. (GMSB)

Chamou-nos a atenção uma das propostas desenvolvidas na rede de ensino que tem como objetivo refletir sobre as características da criança da pré-escola e primeiro ano do ensino fundamental, focando estudos e ações dos professores. Conforme relato da gestora municipal, a formação é desenvolvida com professores da educação infantil e primeiro ano, em três escolas que contemplam os dois segmentos de ensino, por um assessor contratado pela secretaria. São realizados estudos mensais com propostas didáticas que são aplicadas e acompanhadas in loco pelo formador responsável e pela equipe da secretaria de educação, com análises posteriores baseadas no que foi observado à luz dos estudos realizados.

Embora represente uma ação bastante inovadora, os aspectos observados não são ainda socializados com os demais professores da rede que atuam nesses segmentos, representando uma ação isolada das demais.

Embora não seja objetivo específico analisar a fundo o processo de formação da cidade, mas que representações possuem sobre o tema os profissionais que lá atuam, percebemos uma forte preocupação em oferecer capacitação aos professores. No entanto, parece faltar ao sistema a sistematização de diretrizes que amparem as escolas quanto aos processos de formação. Neste sentido, não observamos indícios de propostas fomentadas pela secretaria de educação que estejam impulsionando as reflexões sobre o papel do professor e da escola como atores na construção dos saberes necessários à 
prática educativa, enfatizando as formas de condução dessas formações no interior da escola.

A diversidade de propostas de formação, bem como a inovação anunciada por algumas delas, através do observado nas ações desenvolvidas pela secretaria de educação, como também em algumas das ações que ocorrem no interior das unidades, parece oferecer um terreno fértil para que ações isoladas possam se converter, através da socialização e estabelecimento de metas mais claras, na concretização de verdadeiras obras, no sentido que nos propõe Lefebvre, sem com isso esquecer o que se constitui condição sine qua non dentre os princípios externados nas falas das entrevistadas: a autonomia e a responsabilidade de cada unidade na condução de suas propostas.

\subsection{Representações sobre formação contínua}

\subsubsection{Representação sobre formação contínua pelos gestores municipais}

Além de fornecer subsídios para a compreensão das propostas de formação do município, as entrevistas realizadas nos permitiram avançar na compreensão das manifestações dos referidos gestores, desvelando de que forma se constituíam em representações orientadoras de palavras e ações na condução de propostas voltadas para a área.

Apresentaremos, a partir de agora, a análise das representações dos gestores entrevistados no Sistema B a partir das duas categorias de análise criadas: 1. A formação contínua como meio de melhorar os resultados do sistema; 2. A formação contínua como responsabilidade de outrem.

\subsubsection{Formação contínua como meio de melhoria nos resultados das} avaliações externas

A ideia de formação contínua como meio de melhoria nos resultados das avaliações externas pode ser identificada nas manifestações do gestor municipal e gestor escolar (diretora de escola) do Sistema B.

Como se pode observar no excerto abaixo, o discurso da gestora municipal em

relação à presença da avaliação externa como fator determinante na condução dos objetivos de formação é bastante enfático ao não incluí-la como um elemento direcionador das políticas de formação. 
Não direcionaram. A preocupação foi mesmo um levantamento da primeira etapa. Desse primeiro grupo, não de coordenação, mas da equipe mesmo da secretaria de educação. Quando essa equipe entrou, ela se preocupou mesmo em fazer um levantamento, um diagnóstico da realidade das escolas sem a preocupação com o SAREM, SARESP (...). (GMSB)

As avaliações externas em nível municipal, estadual e federal representam, segundo a gestora municipal, uma avaliação diagnóstica, permitindo a análise do trabalho docente desenvolvido na rede com vistas à elaboração de propostas de formação que ofereçam subsídios para a melhoria de seu desempenho. No entanto, ainda que reconheça a função diagnóstica dessas provas, contradiz-se ao estabelecer relação entre a necessidade de capacitar os professores a partir dos resultados obtidos nas avaliações e ao declarar que não direcionam a formação.

É, uma consulta mesmo. De como estavam as escolas, da necessidade dos professores, pensando nas produções textuais, na função social da escrita, pensando mesmo: Será que isso está acontecendo nas escolas? Está havendo uma preocupação dos professores com relação a isso? Nossa educação está voltada para o ensino técnico, mas sem reflexão do processo? Reflexão pelas crianças, pelos professores, pela coordenadora. Não um processo de reflexão do aprendizado só da equipe técnica. Ou só do grupo de coordenadores. Isso não pode. $\mathrm{Na}$ nossa concepção isso não pode acontecer. Tem que passar pelo professor, inclusive pela criança. Agora, como fazer isso? Então, como fazer isso, se você não tem o professor que não está capacitado pra fazer isso, então você tem que capacitar. Então foi essa a nossa preocupação inicial. (GMSB)

Tal posicionamento conduz para a proposição de uma formação contínua que tem como foco a capacitação de professores voltada para as áreas de língua portuguesa e matemática, como também se pode verificar através do conjunto dos temas abordados nos cursos e oficinas oferecidos. Ainda que haja, como observado, preocupação em melhorar a atuação dos professores para a melhoria dos resultados de ensino no sistema, a preocupação com essas áreas, alvo das avaliações externas, parece representar um fator limitador na diversificação dos temas abordados. Nesse sentido, não observamos nas falas dessa gestora, nem nas áreas do conhecimento contempladas na formação do sistema do qual faz parte, um enfoque para as áreas de ciências ou história, por exemplo. Além disso, a utilização dos dados da avaliação externa municipal como direcionador das ações de formação do município também revela o mesmo. 
Para a gestora escolar do mesmo sistema, os resultados do IDEB também se constituíram como determinantes na condução das ações de formação da unidade escolar onde atua. Conforme relata, o índice representou um "divisor de águas", impulsionando mudanças importantes nas formas de conduzir as formações na escola.

Meu marco divisor foi em 2006 quando saiu o resultado da prova Brasil de 2005(...) A minha escola estava com 5,2. (...) Tinha ficado abaixo da média do município. Com tudo isso que a gente estuda. Eu tenho um perfil de grupo lá de pessoas responsáveis, na sua grande maioria são pessoas que arregaçam a manga e que querem ver acontecer.(...) E quando foi 2006 que saiu essa nota, eu me desesperei. Eu vim aqui e falei com o professor XX. Falei pro professor: Me ajuda, o que eu estou fazendo de errado?(...). Então ele falou assim: Diretora, tudo isso que você falou é verdade (...) o que está faltando é você ver assim, o que está sendo estudado e aprofundado no $\mathrm{HEC}^{22}$, teorizado, o professor está conseguindo transpor todo dia lá pra sala de aula dele?(...). A partir daí, em 2006, começo de 2007, eu comecei a trabalhar na escola com rotinas didáticas.(...) A nossa escola foi a primeira a trabalhar com etapas de produção de texto, com revisão de texto. Então eu comecei: tudo o que nós aprofundamos e estudamos, todos estudam e participam, formatamos uma opinião, um consenso de que aquilo vai ser bom e transformamos em rotina. É uma rotina da escola, semanalmente, quinzenalmente, aquilo tem que acontecer. (GESB)

Parece haver, no caso dessa gestora escolar, uma nova maneira de conceber a formação que desenvolvia na escola a partir da constatação dos resultados obtidos. Tais reflexões, realizadas conjuntamente com assessoria da secretaria de educação, conduziram a novas posturas na orientação das propostas de formação da unidade e inovadoras formas de articular a relação teoria/prática a partir do que denomina "marco divisor".

Isso parece revelar um novo entendimento com relação ao papel do professor na construção de seus saberes, ao mesmo tempo em que reforça a atuação dos gestores escolares na condução e responsabilização pelo processo.

Eles participam ativamente fazendo. Não só estudando teoricamente. Nós praticamos. Por exemplo: Nós estamos trabalhando com estratégias de leitura: síntese e sumarização, antecipação, conhecimento prévio, estratégias de leitura. Então, além de estudarmos o material teórico, depois a coordenadora pratica aquilo com os professores, ela faz a prática pros professores assistirem e depois ela lança um livro, uma sugestão pro professor preparar para o

${ }^{22}$ HEC - Horário de Estudos Coletivo 
próximo HEC e ele apresenta em forma de oficina. Ele fazendo com o grupo. (GESB)

O novo entendimento do papel do professor em seu processo de formação contínua por parte da gestora escolar do Sistema B parece constituir-se em uma ação independente no conjunto das demais ações de formação do município, uma vez que tal concepção não pode ser verificada na fala da gestora municipal.

Mesmo reconhecendo a ligação entre formação de professores e resultados observados, o incentivo para que o professor participe ativamente do seu processo de produção de conhecimento pedagógico fica mais no discurso. Embora a gestora municipal reconheça o ser humano como um sujeito inacabado, ao ser perguntada sobre o papel ativo do professor nesse processo, argumenta mais em favor de seu papel mediador junto aos alunos, em favor da responsabilidade que tem diante da promoção de interação através de seu papel mediador, sem explicitar as formas pelas quais o professor, a partir de propostas de formação contínua, teria a possibilidade de construir tais saberes.

(...) uma coisa que nos faz observar. Como é que o professor se entende enquanto sujeito, enquanto mediador, enquanto uma pessoa responsável mesmo pelo desenvolvimento do aluno (...). Será que ele está se enxergando mesmo nesse processo? Será que ele está se enxergando enquanto sujeito ativo, enquanto uma pessoa que vá promover toda essa mediação entre o conhecimento e o aluno? Então é preciso que ele se perceba uma pessoa também em processo de construção.(...) se eu defendo e penso numa teoria que pensa no sujeito como apropriação de todo conhecimento histórico e social da humanidade, nós ainda estamos produzindo conhecimento. Então nós ainda estamos produzindo conhecimento, não só do sujeito, do sujeito pronto e acabado. Então eu também tenho que me envolver nessas novidades que vão surgindo. (GMSB)

Ainda que não fosse possível identificar grandes inovações a partir da representação que exprime, a gestora parece demonstrar consciência sobre a necessidade de formação permanente com vistas a uma atuação docente que ao mesmo tempo se reconheça e reconheça o outro como sujeito na relação ensino-aprendizagem.

Nesse sentido, consideramos importante destacar o clima percebido durante a realização das entrevistas com as duas gestoras, durante as quais o conjunto de atitudes - gestos, entonação de voz, postura corporal, terminologia utilizada - revelou indícios de posicionamentos profissionais engajados e focados nas questões 
pedagógicas e de aprendizagem, demonstrando serem elas possuidoras de um sentimento de pertencimento de alguém que se sente responsável pela promoção da mudança. É o que, em parte, pode ser percebido no trecho a seguir. Ao questionarmos a diretora de escola sobre sua presença nos momentos de formação na unidade, assim descreveu:

Tudo, nós três! Tudo, o tempo inteiro, nos HECs nós estamos presentes. A vice-diretora vai fazendo registrando tudo que vai acontecendo pra ajudar no relatório de HEC, ela ajuda a coordenadora a fazer. (...). (...) a parte que eu mais gosto é o pedagógico. Eu não nasci pra ser diretora eu nasci pra ser coordenadora, mas sou diretora. (...) a parte que eu mais gosto é o pedagógico. Às vezes eu acho até que sou negligente em outras partes em função do pedagógico. Já teve ocasiões de tirar a funcionária da limpeza, mas ela tinha curso de pedagogia, tirava ela da limpeza e colocava ela na sala de aula pra ajudar o professor. Então o meu foco (pausa) eu prefiro que a escola não fique tão limpa, mas que o pedagógico ande. Então eu, a coordenadora e a vicediretora estamos sempre juntas, as três. Nenhuma das três é administrativa, as três, o foco é pedagógico. É lógico que eu cuido da parte administrativa a contento, mas não é o que eu gosto. (GESB)

Tais posturas, assim como a representação que essas gestoras possuem sobre formação permanente, parecem revelar o comportamento de profissionais que se comprometem com a mudança, pois, cada uma, a seu modo e em seu campo específico de atuação, demonstra responsabilizar-se pela proposição de inovações no campo da formação contínua de professores.

\subsubsection{Formação contínua como responsabilidade de outrem}

Como vimos, é possível reconhecer nas falas da gestora municipal e da diretora de escola um forte posicionamento quanto à autonomia de ambas na condução das propostas de formação no âmbito de atuação de cada uma delas.

Tais sinais não puderam ser identificados na fala da coordenadora pedagógica deste sistema de ensino. Sua fala cautelosa, econômica e reservada pouco mostra suas posições em relação à formação contínua. Seu tom de voz não revela inconformismo ou críticas às propostas veiculadas. Ao mesmo tempo, não é possível notar suas convicções ou posicionamentos pessoais tão engajados quanto o observado, por exemplo, na fala da diretora de escola entrevistada e em relação ao que considera importante no processo de 
formação contínua. De forma cautelosa, limita-se a descrever sucinta, genérica e formalmente as ocorrências da formação a partir do que lhe é perguntado.

Bastantes exemplos: elas mostram pra gente de como intervir, de como fazer em determinado assunto. Tudo isso é repassado. (...) Nada é imposto e sim oferecido. (...) É que a gente sempre procura enfatizar as necessidades da escola. Então tem assuntos abordados aqui que, por enquanto, a escola não está com dificuldade (...). Tem assuntos que são repassados aqui que eu repasso, mas não com aprofundamento. (CPSB)

Quando questionada sobre o ponto de partida para a realização da formação na escola, ressalta a realidade e as necessidades identificadas, no entanto, o faz de forma genérica, não sendo possível desvendar as formas pelas quais a autonomia proclamada por diversas vezes se faz presente em sua atuação. Nesse sentido, tende a exemplificar mais concretamente as ações de outros como a Secretaria de Educação, a universidade, etc.

A articulação teoria e prática aparece mais como uma atitude voluntária do professor e acontece como uma consequência de cursos que realiza fora da unidade escolar e menos como uma ação resultante de propostas de formação pensadas pela equipe da unidade escolar, diferentemente do que ocorre na unidade da diretora de escola entrevistada cuja proposta de aplicação prática é mais fortalecida. Pelo que se infere, tais iniciativas são deixadas unicamente a critério do professor.

$\mathrm{O}$ que se percebe é que a maioria dos professores que se disponibilizam a fazer esses cursos procuram levar para a prática sim de sala de aula e dar um retorno prá gente, se está dando certo, se não está. Então, esse espaço do HEC também é pra isso. Há essa socialização e há esse tempo pra aplicar em sala de aula. Então eles dão a devolutiva pra gente. Se algo está funcionando, se ainda não, se eles precisam melhorar. (CPSB)

Quando questionada se os professores aplicam as práticas por iniciativa própria, afirma que sim, pois, segundo ela, eles precisam perceber tal necessidade. Em suas palavras: "Tudo que é imposto, a gente percebe que não está fazendo porque gostou ou porque acredita e sim porque é imposto"

A presteza nas informações de que dispõe ao descrever a formação contínua desenvolvida pelo município e pela unidade escolar revela uma profissional organizada e ciente de seus deveres. Evidentemente, só uma análise mais profunda de suas ações 
poderia nos conduzir de forma mais assertiva às representações que possui sobre o tema. No entanto, a ausência de elementos mais concretos trazidos como exemplos de uma atuação mais autônoma não nos permitiu reconhecer este nível de realidade. Além disso, seus posicionamentos quanto a uma participação mais ativa por parte dos professores nos leva a atribuir a coordenadora pedagógica uma representação de formação contínua como responsabilidade de outrem, faltando-lhe um sentido maior de autoria e engajamento na proposição de inovações na área.

\subsubsection{Representação de Formação Contínua pelos professores da rede}

As manifestações sobre formação contínua foram obtidas através da realização de um Survey, enviado a 343 professores. Desse total, 327 retornaram, representando uma devolutiva de $92 \%$ dos questionários.

Com base na análise da primeira seção de perguntas, traçamos um breve perfil dos professores do Sistema B. Dos professores que responderam ao questionário $90 \%$ declararam ser efetivos, $17 \%$ afirmaram trabalhar em outra unidade, sendo que desse percentual, $68 \%$ em outra escola pública.

Quanto à formação, 72\% declararam possuir magistério em nível médio e 89\% possuir pedagogia. Dentre os que possuem pedagogia, $17 \%$ ainda declararam possuir outra licenciatura. Com relação à formação em nível de pós-graduação, apenas $25 \%$ dos professores afirmaram possuir esse nível de formação.

As manifestações obtidas por esse instrumento foram classificadas em duas categorias, já explicitadas antes: 1. Fatores que mais motivam a participação na formação contínua; 2. Expectativas sobre formação contínua e sua relevância para a prática. É o que passaremos a expor.

\subsubsection{Fatores que motivam a participação na Formação Contínua}

Com o objetivo de identificar as motivações dos professores sobre sua participação na formação contínua procuramos abordar esse aspecto através da análise do que foi espontaneamente apontado por eles como motivação para a participação e através de questões diretas sobre seu posicionamento em relação à ligação entre formação contínua e valorização na carreira. Analisamos, ainda, suas repostas quanto à 
frequência nos cursos oferecidos e as informações sobre sua formação em nível de pósgraduação.

Apresentamos na tabela a seguir os principais fatores apontados pelos professores sobre o que motivaria sua participação em cursos de formação continuada.

\section{Tabela 10- Fatores que mais motivam a participação nos cursos oferecidos ${ }^{23}$}

\begin{tabular}{|l|c|}
\hline Motivação para participação & Sistema B ${ }^{24}$ \\
\hline Aprimoramento da Prática & $33 \%$ \\
\hline Atualização/Novos conhecimentos & $31 \%$ \\
\hline Relevância/Qualidade do curso & $15 \%$ \\
\hline Melhorar profissionalmente & $8 \%$ \\
\hline Socialização/Reflexão sobre a prática & $6 \%$ \\
\hline Progredir na carreira/obter certificação & $2,5 \%$ \\
\hline Não há motivação/ É obrigação & $0,5 \%$ \\
\hline Disponibilidade de horário & $4,0 \%$ \\
\hline
\end{tabular}

Conforme mostra a tabela, os professores do Sistema B tendem a posicionar-se de maneira clara em relação às suas motivações para a participação na formação contínua, sendo apenas de $39 \%$ o percentual das manifestações pautadas em motivações pouco esclarecedoras. Desses, 31\% se referem a "formar-se em busca de melhoria profissional e atualização" e $8 \%$, "melhorar profissionalmente".

Dessa forma, $61 \%$ das manifestações indicam mais concretamente as motivações de participação, sendo que, desse total, 54\% apontam para as questões mais ligadas à prática pedagógica como o "aprimoramento da prática", com 33\%, figurando como o maior percentual de manifestações dentre os professores do Sistema, "a relevância e qualidade dos cursos", com $15 \%$, e a socialização e reflexão sobre a prática, com $6 \%$.

\footnotetext{
${ }^{23}$ As porcentagens da tabela referem-se ao conjunto das manifestações dos professores de cada sistema pesquisado.

${ }^{24} 327$ professores e 350 manifestações
} 
Ainda assim, há entre esses professores aqueles que apontam de forma concreta para motivações ligadas à carreira e progressão funcional $(2,5 \%)$ e disponibilidade de horário (4\%).

Cabe ressaltar que, dentre os três sistemas estudados, é o Sistema B cujos professores manifestaram de forma mais enfática motivações ligadas à prática pedagógica. Além disso, observa-se, dentre os três, o menor percentual de manifestações ligadas à carreira profissional.

Assim como os professores do Sistema A, 100\% dos professores do Sistema B concordam que os cursos de formação sejam contados para a progressão na carreira. No entanto, apenas $8 \%$ afirmam ser esta uma condição para a participação.

Houve também dentre os professores do Sistema B aqueles que se manifestaram para além da questão. Dentre os $92 \%$ que afirmaram participar ainda que a formação não fosse contada, tivemos as seguintes declarações: "por ética, profissionalismo", "porque quero aprimorar-me, mas considero motivadores os benefícios", "a criança é o foco", "dos que me interessam", "se for de interesse (os cursos não são contados)", "com certeza" e "se for interessante, dentro do horário". Dentre os que afirmaram não participar (8\%), uma professora declarou: “os cursos não acrescentam nada, ou muito pouco em sala de aula".

Mesmo notando-se na fala desses professores certo engajamento com relação às questões ligadas à formação, nota-se, ainda, um número elevado de professores neste sistema de ensino que afirma participar "às vezes" dos cursos de formação. À questão: "Com que frequiência você participa de cursos de formação oferecidos pelo município?", 35\% afirmou participar "sempre”, e, 64\% “às vezes".

Um dos professores respondeu para além da questão, afirmando não participar "nunca". Todos os demais se limitaram a responder a questão de forma objetiva.

A relação entre formação e carreira também pode ser notada no Sistema B. Não contando em seu plano de carreira com a possibilidade de progressão por via acadêmica, nota-se um baixo número de professores com formação em nível de pós-graduação. 
Tabelas 11 - Percentuais de formação em nível de pós-graduação manifestos pelos professores

\begin{tabular}{|c|c|}
\hline Possui curso de pós-graduação? & Sistema B \\
\hline Lato Sensu & $23, \%$ \\
\hline $\begin{array}{c}\text { Stricto Sensu } \\
\text { (mestrado) }\end{array}$ & $2,5 \%$ \\
\hline Total & $25,5 \%$ \\
\hline
\end{tabular}

Ainda assim, é o Sistema que possui o maior percentual dentre as declarações de formação em nível de pós-graduação stricto sensu.

Em síntese, a análise das representações dos professores sobre o que motiva a participação na formação contínua nos leva a considerar a interferência das especificidades locais na maneira de agir e pensar seus processos de formação.

No Sistema B, como já analisado, temos um cenário em que as propostas de formação apresentam-se de maneira mais efetiva, com uma ampla oferta de cursos e oficinas. Os professores vinculam de maneira significativa a ideia de formação e prática pedagógica, expressando-se positivamente em relação ao compromisso com a aprendizagem, mesmo sem uma formação com vistas à progressão funcional. Dentre os professores dessa rede, apenas 2,5\% das repostas sobre a principal motivação indicam tal fator como motivador, ainda que 4,5\% tenham apontado a disponibilidade de horário como condição de participação.

O Sistema B, que proporciona o menor número de horas dentro da carga horária para formação, também não prevê em sua legislação nenhum tipo de vantagem àqueles que realizam cursos de formação contínua, sejam eles na modalidade acadêmica ou nãoacadêmica. Nesse sentido, observa-se um número elevado de professores que afirmam participar "às vezes" da formação - 64\%. Além disso, o sistema possui, dentre os três, o menor índice de professores com pós-graduação (25,5\%). No entanto, 2,5\% desses professores possuem essa formação em nível stricto-sensu, contra $0,5 \%$ no Sistema A e $0 \%$ no Sistema C na mesma modalidade.

\subsubsection{Expectativas sobre a formação contínua e sua relevância para a prática}

Conforme explicitado, as questões que compuseram esta categoria de análise tinham como objetivo desvelar representações sobre formação contínua, considerando a 
manifestação dos professores em relação às suas expectativas quanto ao formato de cursos, áreas do conteúdo a serem contempladas e relevância desses cursos de formação para a prática pedagógica. Também como uma forma de conhecer as expectativas de formação contínua, solicitamos que avaliassem os cursos oferecidos a partir de questionamentos em relação à articulação entre teoria e prática.

A primeira questão dessa categoria de análise focava a avaliação que os professores fazem dos cursos de formação oferecidos, tendo três alternativas como opção: 1. São muito teóricos e não se relacionam com a realidade da escola; 2. Apresentam apenas receitas prontas, sem explicar o porquê das coisas; 3 . Outra.

Como pudemos perceber, os professores do Sistema B tendem a se manifestar mais favoravelmente em relação à formação contínua oferecida pelo município. Totalizando um percentual de $54 \%$ de manifestações que parecem avaliar os cursos oferecidos de forma positiva, percebe-se que esses professores reconhecem a contribuição dos cursos oferecidos para a prática pedagógica.

Os $46 \%$ que tendem a avaliar negativamente os cursos, o fazem devido ao fato de considerarem os cursos muito teóricos. Desses, apenas 2\% parecem entender faltar fundamentação teórica aos cursos, optando por classificá-los apenas como transmissão de receitas prontas. Os $3 \%$ que estabelecem outras críticas, fazem-no a partir de justificativas variadas. Para estes, os cursos oferecidos "São ministrados por pessoas sem experiência de sala de aula", "Precisam de maior aprofundamento", "São sempre oferecidos em horário de difícil participação".

Procurando desvelar a relação que estabelecem entre o formato dos cursos oferecidos e sua contribuição para a produção de novos conhecimentos pedagógicos, solicitamos aos professores que apontassem espontaneamente qual o formato de curso consideram mais apropriado para a formação contínua.

É possível perceber que, ao escolher os formatos dos cursos, os professores do Sistema B tendem a optar por aqueles cujos formatos privilegiem a relação teoria e prática, somando um total de $49 \%$. Dentre estes, $24 \%$ que afirmam preferir os "cursos com teoria e prática", e, para tanto, justificam-se mais a partir da necessidade de que a capacitação em serviço privilegie as questões da prática que definindo sua articulação com a teoria. Ainda desse total, 18\% afirmam preferir "cursos práticos com pouca teoria", fazendo a opção a partir das mesmas justificativas apontadas por aqueles que, aparentemente, optam pela articulação entre as duas. Dos $7 \%$ que afirmam preferir cursos com troca de experiência, ninguém justificou. 
É relevante também o percentual de professores que indicam o formato mais adequado justificando suas escolhas a partir do aproveitamento dos cursos. Tais preferências representaram um total $38 \%$ das manifestações dentre as quais destacam-se $18 \%$ que optam por formatos presenciais, a partir das seguintes justificativas: "relaciona teoria e prática", "permite troca de experiências", "é mais dinâmico", "posso esclarecer dúvidas", dentre outras que apontam também para a importância do contato e trocas entre os participantes. Um dos professores acrescentou a sua escolha a possibilidade que esta modalidade oferece "para que o professor não seja só ouvinte".

Ainda na perspectiva de escolhas baseadas no aproveitamento do curso, as justificativas sobre a preferência por módulos de curta duração enfatizam aspectos como a possibilidade de se abrangerem vários temas, de se conhecer o conteúdo com antecedência, de proporcionar momentos de reflexão, além de não ser "cansativo". Nas opções por cursos de frequência semanal ou quinzenal, os $11 \%$ que indicam ser este o melhor formato por conta da "constância na aprendizagem".

Como pudemos notar, é de apenas $10 \%$ o percentual de professores que fazem a escolha do formato dos cursos de capacitação considerando aspectos de praticidade. Dentre as justificativas apresentadas estão a "flexibilidade de horário" e a "facilidade".

Perguntamos também aos professores quais os temas que consideravam importantes serem abordados nos cursos de formação contínua e obtivemos os seguintes dados:

\section{Tabela 12 : Principais temas/áreas apontadas para a abordagem na formação contínua}

\begin{tabular}{|c|c|}
\hline Tema/área & Percentual de respostas $^{25}$ \\
\hline Matemática & $17 \%$ \\
\hline Todas as áreas & $16 \%$ \\
\hline Língua Portuguesa & $16 \%$ \\
\hline Dificuldades de aprendizagem & $11 \%$ \\
\hline Metodologias de Ensino & $14 \%$ \\
\hline Alfabetização e Letramento & $8 \%$ \\
\hline Conforme a necessidade & $5 \%$ \\
\hline Artes & $4 \%$ \\
\hline Temas transversais & $4 \%$ \\
\hline Ciências/Meio Ambiente & $3 \%$ \\
\hline Educação Física & $1 \%$ \\
\hline Ética profissional & $1 \%$ \\
\hline
\end{tabular}

\footnotetext{
${ }^{25} 530$ declarações.
} 
Percebe-se que, embora haja um número significativo de indicações para as áreas da língua e da matemática (41\%), há uma distribuição maior entre as áreas e disciplinas eleitas como prioritárias. Mesmo sendo a matemática a área com maiores indicações, englobando, dentre as respostas, as técnicas de raciocínio matemático e a geometria, há um percentual considerável de manifestações que indicam o desejo por cursos que contemplem todas as áreas (16\%).

Nota-se, ainda, que, ao indicar as áreas da língua, não prevalecem as questões da alfabetização e letramento, representando estas apenas $8 \%$ das manifestações.

Tais indicações podem aprofundar a reflexão sobre a influência do tipo de oferta feita pelo sistema de ensino na escolha dos principais temas, como as áreas da língua e da matemática - alvo das avaliações externas - como também nas demais possibilidades ofertadas para as outras áreas do conhecimento, como se percebe na análise das propostas de formação. O que isso parece dizer é que, mesmo havendo uma concentração maior na oferta de cursos voltados ao estudo da matemática e da língua, a diversidade e quantidade de cursos oferecidos pelo município podem estar estimulando os professores a considerarem outras possibilidades de formação, além das voltadas para o estudo da língua e da matemática.

Sobre a relevância da formação para o enfrentamento dos desafios pedagógicos enfrentados pelos professores, uma maioria significativa considera determinante o trabalho que se faz, individual ou coletivamente, na escola. É o que se pode observar na tabela abaixo.

Tabela 13: Relevância da formação contínua para o enfrentamento dos desafios pedagógicos

\begin{tabular}{|c|c|c|c|}
\hline $\begin{array}{c}\text { O trabalho } \\
\text { individual e } \\
\text { coletivo da escola }\end{array}$ & $\begin{array}{c}\text { A ajuda externa } \\
\text { possibilitada } \\
\text { pelos cursos }\end{array}$ & \multicolumn{2}{|c|}{ Outra } \\
\hline \multirow{4}{*}{$72 \%$} & \multirow{4}{*}{5} & Os dois & $20 \%$ \\
\cline { 3 - 4 } & \multirow{4}{*}{5} & Não respondeu & $1,8 \%$ \\
\cline { 3 - 4 } & & Todos abraçarem a causa & $0,3 \%$ \\
\cline { 3 - 4 } & & $\begin{array}{c}\text { Recursos humanos, diferentes } \\
\text { profissionais }\end{array}$ & $0,3 \%$ \\
\cline { 3 - 4 } & & Prática fora da escola & $0,3 \%$ \\
\cline { 3 - 4 } & & $\begin{array}{c}\text { A vontade do professor e o gosto por } \\
\text { trabalhar nessa profissão }\end{array}$ & $0,3 \%$ \\
\cline { 3 - 4 } & & Apoio da escola & $0,3 \%$ \\
\hline
\end{tabular}


Ainda que seja grande o percentual de professores que focam exclusivamente o trabalho desenvolvido pela escola (72\%), é também significativo o percentual de professores que incluem os cursos ofertados como importantes para o enfrentamento dos desafios pedagógicos, uma vez que $20 \%$ dos professores indicam para isso. Como se pode observar é de apenas 5\% o percentual de professores que atribuem exclusivamente aos cursos ofertados maior relevância no enfrentamento de tais desafios.

Nesse mesmo sentido, ao tentarmos articular a ideia de aquisição de conhecimentos baseados na prática educativa aliada aos cursos de formação, também perguntamos aos professores a quais fatores atribuíam seus atuais conhecimentos pedagógicos. Como se pode notar, a grande maioria atribuiu seus conhecimentos à prática e aos cursos realizados, sendo muito baixo (1\%) o percentual de professores que atribuíram seus conhecimentos pedagógicos unicamente ao curso de graduação realizado.

\section{Tabela 14: Principais contribuições à construção de conhecimento pedagógico}

\begin{tabular}{|c|c|l|c|}
\hline $\begin{array}{c}\text { A minha prática e aos } \\
\text { cursos realizados }\end{array}$ & $\begin{array}{c}\text { Ao meu curso de } \\
\text { graduação }\end{array}$ & \multicolumn{2}{|c|}{ Outra } \\
\hline $82 \%$ & $1 \%$ & As duas opções & $15 \%$ \\
\hline
\end{tabular}

Ainda assim, 15\% desses professores consideram as duas opções, havendo também um percentual de professores que se manifestaram para além da questão. Desses, 3,6\% indicaram outros tipos de estudos como "pesquisa/mestrado", "grupo de estudo", "leituras", "CEFAM", "HEC" e "disciplinas realizadas na universidade".

O que podemos concluir, a partir da análise das manifestações a respeito das expectativas sobre a formação contínua e sua relevância para a prática, é que os professores do Sistema B tendem para uma avaliação positiva, reconhecendo as contribuições da capacitação docente oferecida pelo município no enfrentamento dos desafios pedagógicos, ainda que uma parcela desses profissionais manifeste o desejo de uma formação mais focada nas questões práticas. Tal aspecto parece ser reforçado 
quando os professores indicam o trabalho individual e coletivo da escola como mais relevantes para o enfrentamento de tais desafios.

Neste sentido, é também a prática pedagógica e o aproveitamento dos cursos os fatores mais importantes a serem considerados ao eleger o formato mais adequado de cursos.

Quanto aos temas e áreas do conhecimento, destacam-se as áreas da língua e da matemática, mas merece destaque a indicação por cursos que abranjam todas as áreas, revelando certo equilíbrio dentre os temas apontados como prioritários.

Há, como se pode perceber, uma grande expectativa dos professores por uma formação que dê conta de suas reais necessidades e que privilegie a escola como lócus de formação, embora, pelo que se infere a partir da avaliação que fazem das propostas de formação do município, o sistema tem conseguido corresponder à expectativa da maioria dos professores.

\subsection{As representações sobre formação contínua e o foco na prática pedagógica}

Conforme vimos, o Sistema B possui uma legislação educacional bastante desatualizada, que não garante à equipe da secretaria de educação uma estrutura formal de cargos cujas atribuições atendam às demandas de formação contínua do município, o que obriga a atual gestão a improvisar, por meio dos cargos disponíveis, um organograma condizente ao que se deseja. Constata-se, ainda, que no plano de carreira do magistério não se vislumbram incentivos à formação, com exceção das duas horas previstas apenas na jornada dos professores do ensino fundamental.

As entrevistas realizadas e os cronogramas de formação fornecidos revelaram que a secretaria de educação toma para si a responsabilidade de capacitar seus professores, oferecendo uma gama de cursos aos segmentos de educação infantil, ensino fundamental e gestão, além de conduzir semanalmente junto aos coordenadores pedagógicos estudos sobre os conteúdos a serem contemplados nos encontros de formação ocorridos nas escolas entre os professores de ensino fundamental, o HEC. Há que se ressaltar que, mesmo havendo direcionamento dessas ações por parte da equipe da secretaria de educação, percebe-se grande abertura para o exercício da autonomia nas unidades em relação ao repasse dessas propostas que, conforme enfatizado pelas três gestoras, é de aplicação facultativa, devendo adequar-se a cada realidade em particular. 
Verifica-se, em relação à condução dos processos de formação contínua nas escolas, um diagnóstico bastante focado nos resultados das avaliações externas, o que nos permitiu atribuir à gestora municipal e a diretora de escola uma representação de formação contínua com foco nos resultados. Ao mesmo tempo, o engajamento e responsabilidade pela melhoria da prática pedagógica, bem como as inovações propostas, ainda que pontuais, apontam para a superação dessas representações, aproximando-se de verdadeiras obras, conforme sinaliza Lefebvre. Em relação à representação sobre formação contínua atribuída à coordenadora pedagógica, não foi possível formular as mesmas hipóteses. Ainda que inserida no contexto de formação orientado no Sistema, não pareceu possuir o mesmo engajamento, autoria e autonomia na proposição de inovações focadas em sua unidade escolar.

A vasta oferta de possibilidades de formação, oferecidas nos cursos disponibilizados pelo município, bem como a formação articulada junto aos coordenadores pedagógicos indica uma ênfase especial nos conteúdos a serem ministrados que no desenvolvimento de metodologias que forneçam aos gestores escolares o desenvolvimento de estratégias de intervenção na prática. Ainda assim, é possível perceber um conjunto de propostas de formação e de representações de gestores cujo foco centra-se na prática pedagógica. Tais elementos, somados a outros aspectos da realidade observada, constituem o pano de fundo para a análise das manifestações dos professores do Sistema.

A boa devolutiva dos questionários enviados aos professores nos deu a possibilidade de apreendermos dados mais concretos sobre a realidade estudada, alcançando de maneira mais efetiva as representações que os professores do Sistema mantêm sobre formação contínua.

A análise das manifestações, divididas nas duas categorias analisadas - fatores que motivam os professores a participar da formação contínua e expectativas sobre a formação contínua e sua relevância para a prática - nos fez concluir que os professores tendem a se motivar e a desejar um processo de formação profissional que atenda às demandas do cotidiano, fornecendo elementos concretos para o enfrentamento dos desafios impostos pela prática pedagógica Ao mesmo tempo, esses professores avaliam positivamente as propostas de formação desenvolvidas na rede, ainda que mais da metade desses professores afirme participar "às vezes” dos cursos oferecidos.

É quase inexistente no conjunto dessas manifestações a vinculação entre carreira e formação, ainda que reconheçam a validade de estímulo na carreira por meio da 
realização de cursos. Da mesma forma, ao eleger os formatos mais adequados para os cursos, poucos consideram os fatores de ordem pessoal e prática, sendo que a maioria desses professores manifestam sua opção a partir de justificativas pedagógicas e de aproveitamento dos cursos.

Ao reconhecermos que as representações são também originadas pelo contexto onde se insere o sujeito, sendo esse contexto também determinado pelas representações produzidas pelos indivíduos, formulamos os seguintes questionamentos: 1. a ausência de práticas de gestão mais inovadoras por parte da coordenadora pedagógica estaria sendo impulsionada pela falta de maiores investimentos da secretaria de educação ao não construir coletivamente entre os gestores tais estratégias de intervenção efetiva em cada realidade em particular? 2. Tais posturas não estariam também incentivando nos gestores uma busca solitária para resolução dos problemas? 3. A existência de possibilidades de progressão funcional via acadêmica e não acadêmica, somada às propostas de formação desenvolvidas pela rede estimularia a formação de um corpo docente mais qualificado e mais participativo nos programas de formação desenvolvidos pelo município?

Por outro lado, ainda perguntaríamos: Seria o desempenho satisfatório verificado nos índices alcançados pelo município resultado do clima de engajamento percebido através da maioria das representações sobre formação contínua de professores e gestores cujo foco está centrado na prática pedagógica?

Ainda que levantados tais questionamentos e reconhecendo a necessidade de investigações mais aprofundadas para a confirmação da existência de um possível círculo virtuoso originado pelas ações de formação verificadas no Sistema, vimos que a ausência de incentivos na carreira docente não interfere de maneira significativa nas representações que gestores e professores mantém sobre formação contínua, fazendonos insistir na crença de que o investimento na diversidade de propostas de formação oferecida e sua ênfase em resultados pode estar determinando as representações dos profissionais de ensino cujo foco está centrado na melhoria da prática pedagógica. 


\section{O SISTEMA C}

\subsection{Contexto Sócio-econômico, Estrutura da Secretaria de Educação e Plano de Carreira}

O Sistema C pertence a uma cidade situada no noroeste paulista, a 480 quilômetros da capital. Suas atividades econômicas estão voltadas para a agricultura e a pecuária leiteira, além de outras culturas como o arroz e o milho. É a cidade com menor número de habitantes dentre os três municípios em análise.

\section{Tabela 15: Dados sócio-econômicos do município}

\begin{tabular}{|c|c|c|c|c|c|}
\hline População & $\begin{array}{c}\text { Receita do } \\
\text { Município }\end{array}$ & $\begin{array}{c}\text { Renda per } \\
\text { Capita }\end{array}$ & IDHM & $\begin{array}{c}\text { IDHM } \\
\text { Educação }\end{array}$ & $\begin{array}{c}\text { Taxa de } \\
\text { Analfabetismo }\end{array}$ \\
\hline 59.237 & 113.442 .505 & 705,28 & 0,759 & 0,680 & 5,46 \\
\hline
\end{tabular}

Fonte: Fundação Seade. Consulta em 19/03/2014.

No Sistema C, as matrículas registradas no ensino superior na modalidade presencial concentram-se totalmente na rede privada de ensino. Segundo dados da Fundação Seade, a cidade registrou, no ano de 2012, cursos na área de agricultura e veterinária, Ciências Sociais, Negócios e Direito, Educação, Saúde e Bem Estar Social, sendo possível observar, a partir de 2003, acentuado decréscimo nas matrículas presenciais para a área da Educação. Naquele ano observava-se o registro de 715 matrículas presenciais na área, caindo gradativamente a cada ano, chegando a observarem-se, no ano de 2012, apenas 98 matrículas para a área.

$\mathrm{Na}$ educação básica, o ensino médio e os quatro últimos anos do ensino fundamental estão sob responsabilidade da rede estadual de ensino, ficando a cargo do município os segmentos de educação infantil e os anos iniciais do ensino fundamental.

O gráfico a seguir apresenta o movimento das matrículas dos segmentos pertencentes à rede municipal de ensino entre os anos de 1999 a 2013. 
Gráfico 5: Movimento das matrículas na rede municipal de 1999 a 2013

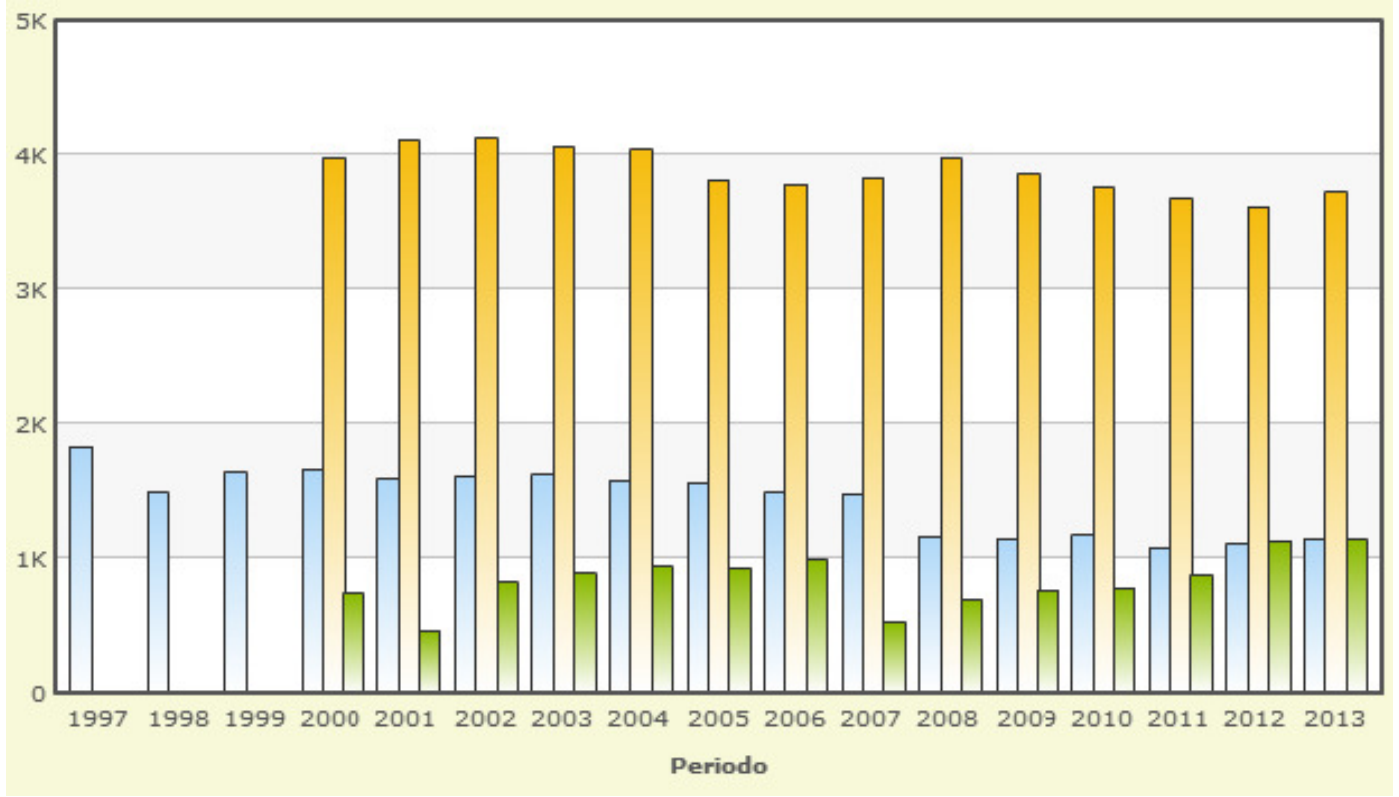

\begin{tabular}{|l} 
Ila Matrícula na Pré-escola - Rede Municipal \\
Wh Matrícula no Ensino Fundamental - Anos Iniciais \\
Wh Matrícula na Creche - Rede Municipal
\end{tabular}

Fonte: Seade

O aumento das matrículas na primeira etapa do ensino fundamental e na etapa de creche indica que, a partir do ano 2000, o município passa a assumir maiores responsabilidades na área da educação, devido à municipalização da primeira etapa do ensino fundamental e da inclusão das creches na área da educação em decorrência das novas diretrizes propostas pela LDB. Assim como os dois outros sistemas pesquisados, há uma sensível diminuição das matrículas na pré-escola em virtude da implantação do ensino fundamental de nove anos na rede. Conforme os dados do senso 2013, o Sistema C possui um total de 4781 alunos, sendo, 1149 na etapa de pré-escola, 2488 nas séries iniciais do ensino fundamental e 1144 na etapa de creche.

Quanto ao desempenho do Sistema nas avaliações externas, apresentamos a trajetória do município em relação aos resultados do Ideb, conforme mostra o quadro a seguir. 


\section{Quadro 10 - Resultado do IDEB - Sistema C}

\begin{tabular}{|c|c|c|c|c|c|c|c|c|c|c|c|c|}
\hline \multicolumn{5}{|c|}{ Ideb Observado } & \multicolumn{8}{|c|}{ Metas Projetadas } \\
\hline $\begin{array}{c}2005 \\
*\end{array}$ & $\begin{array}{c}2007 \\
*\end{array}$ & $\begin{array}{c}2009 \\
*\end{array}$ & $\begin{array}{c}2011 \\
*\end{array}$ & $\begin{array}{c}2013 \\
*\end{array}$ & $\begin{array}{c}2007 \\
\div\end{array}$ & $\begin{array}{c}2009 \\
=\end{array}$ & $\begin{array}{c}2011 \\
\quad \neq\end{array}$ & $\begin{array}{c}2013 \\
\quad *\end{array}$ & $\begin{array}{c}2015 \\
*\end{array}$ & $\begin{array}{c}2017 \\
*\end{array}$ & $\begin{array}{c}2019 \\
*\end{array}$ & $\begin{array}{c}2021 \\
*\end{array}$ \\
\hline 4.7 & 5.2 & 5.8 & 5.5 & 5.9 & 4.7 & 5.1 & 5.5 & 5.7 & 6.0 & 6.2 & 6.5 & 6.7 \\
\hline
\end{tabular}

Fonte: Inep

Observa-se que o Sistema C vem, ao longo da trajetória entre 2005 e 2013, cumprindo as metas estabelecidas para o Sistema. Apresenta, ainda, índice maior que as escolas municipais em nível nacional, que é de 4,9, e também maior que a média das escolas brasileiras que atendem alunos dos anos iniciais do ensino fundamental, que é de 5.2. Em relação às dez unidades escolares avaliadas no Sistema, quatro delas não atingem a meta projetada. Chama atenção a disparidade observada entre os índices obtidos por essas escolas, uma vez que a maior nota é de 7,4 e a menor, 3.3.

Ao analisarmos o desempenho nas duas áreas do conhecimento avaliadas, verificamos que as diferenças entre os melhores e os piores resultados aumentam. Em português, o maior percentual com aproveitamento adequado entre as escolas é de $85 \%$ e o menor, $10 \%$. O mesmo ocorre com o desempenho em matemática, cuja distância entre os melhores e piores é ainda maior. É de $89 \%$ o percentual observado no melhor desempenho contra 5\%, no pior.

Ainda em relação ao aprendizado de português, observa-se que o número de alunos com desempenho adequado cresce de $45 \%$ para $56 \%$. Entretanto, o percentual de alunos com desempenho insatisfatório cresce de 6\%, em 2009, para 16\%, em 2013.

Em matemática o desempenho adequado também cresce de $45 \%$ para $53 \%$, mas, à semelhança do que ocorre em português, o percentual de alunos com quase nenhum aprendizado é alto, saltando de 8\% em 2009 para 19\% em 2013.

Estando constituído enquanto sistema, a rede municipal em questão também atende as etapas de educação infantil, creche e pré-escola e ensino fundamental, séries iniciais.

Ao contrário do observado no Sistema B e à semelhança do Sistema A, a lei que rege o Plano de Carreira do Sistema C é recente, e sua promulgação se deu em 2009.

A referida lei traz em seu bojo todo o conjunto dos cargos destinados à pasta, tendo desde professores e outros cargos providos por concurso até cargos em comissão, 
ali definidos os requisitos de preenchimento de cada um deles, inclusive o cargo de Secretário de Educação.

O quadro do magistério traz a seguinte composição:

\section{Quadro 11 - Composição do quadro do magistério público municipal - Sistema C}

\begin{tabular}{|l|l|}
\hline Efetivos & Cargos em Comissão $^{\mathbf{2 6}}$ \\
\hline Professor I & Diretor de Escola \\
\hline Professor II & Coordenador Pedagógico \\
\hline Professor de Artes & Diretor de Departamento de Ed. Infantil \\
\hline Professor de Educação Física & $\begin{array}{l}\text { Diretor de Departamento de Ensino } \\
\text { Fundamental }\end{array}$ \\
\hline & Supervisor Educacional \\
\hline
\end{tabular}

Fonte: Estatuto do Magistério do Município.

Os profissionais do magistério contam, em sua jornada de trabalho, com uma disponibilidade de tempo bastante significativa no que se refere às horas destinadas à formação contínua. Embora haja certa diversidade de jornada entre os cargos, inclusive os que atendem ao mesmo segmento, todos os professores têm cinco horas semanais destinadas ao HTPC - Hora de Trabalho Pedagógico Coletivo, com vistas: a) à realização do trabalho coletivo escolar, e grupos de formação permanente, de reunião pedagógica ou de reunião de pais; b) ao planejamento, elaboração e avaliação do projeto político pedagógico da escola; c) ao aperfeiçoamento profissional do docente, através de reuniões, palestras, cursos, estudos, e outras atividades correlatas de interesse da Educação. As jornadas docentes estão assim organizadas:

\footnotetext{
${ }^{26}$ Os cargos em comissão que compõem o quadro do magistério denominados suporte pedagógico (Direção, Coordenação) são ocupados por professores contratados para empregos públicos permanentes da rede de ensino, após realização de processo seletivo organizado pela Secretaria de Educação, através do Conselho Municipal de Educação. O tempo de nomeação é de dois anos, renovável por igual período. Os diretores de departamento e o supervisor educacional serão cargos ocupados mediante livre nomeação do Prefeito.
} 


\section{Quadro 12 - Programas de Formação Contínua previstos na jornada semanal de trabalho dos professores do Sistema C}

\begin{tabular}{|c|c|c|c|c|}
\hline Contemplados $^{27}$ & Jornada total & $\begin{array}{c}\text { Jornada com } \\
\text { alunos }\end{array}$ & HTPC & HTPL $^{28}$ \\
\hline $\begin{array}{c}\text { Professor I - Educação } \\
\text { Infantil e Ensino } \\
\text { Fundamental }\end{array}$ & 30 & 20 & 05 & 05 \\
\hline $\begin{array}{c}\text { Professor II - Educação } \\
\text { Infantil e Ensino } \\
\text { Fundamental }\end{array}$ & 30 & 20 & 05 & 05 \\
\hline $\begin{array}{c}\text { Professor I II - } \\
\text { Educação Infantil e } \\
\text { Ensino Fundamental }\end{array}$ & 35 & 25 & 05 & 05 \\
\hline $\begin{array}{c}\text { Professor I e II- Educação } \\
\text { Infantil e Ensino } \\
\text { Fundamental - EJA }\end{array}$ & 15 & 10 & 03 & 02 \\
\hline $\begin{array}{c}\text { Professor de Artes e } \\
\text { Educação Física }\end{array}$ & 40 & - & - & - \\
\hline
\end{tabular}

Fonte: Plano de Carreira do Município.

São contempladas no plano as progressões ${ }^{31}$ obtidas através da realização de formação permanente, garantindo o avanço na carreira pela via acadêmica aos que apresentarem títulos (especialização, mestrado e doutorado), desde que observado o prazo de dois anos entre uma evolução e outra, cabendo ao Conselho Municipal de Educação e à Secretaria de Educação a análise preliminar dos títulos apresentados.

Ainda com relação à evolução por intermédio da realização de cursos, os profissionais podem progredir pela via não-acadêmica, que tem por objetivo reconhecer o crescimento profissional e o magistério público municipal, no respectivo campo de atuação, como um dos fatores relevantes para a melhoria do ensino (LEI COMPLEMENTAR ART. 75).

\footnotetext{
${ }^{27}$ Os cargos de Professor I e II - Educação Infantil e Ensino Fundamental com jornada total de 30 horas serão extintos na vacância.

${ }^{28}$ A HTPL - Hora de Trabalho Pedagógico de Livre Escolha é destinada ao planejamento de aulas e materiais pedagógicos.

${ }^{29}$ Educação de Jovens e Adultos.

${ }^{30}$ As horas dedicadas ao trabalho coletivo e horas de trabalho de livre escolha são compatibilizadas pela Secretaria de Educação, conforme grade curricular.

${ }^{31}$ Os profissionais do magistério público municipal podem evoluir na carreira pelas vias acadêmica e não acadêmica, pelos processos de avaliação de desempenho e pela evolução do tempo de serviço.
} 
Conforme estabelece o plano de carreira, os professores devem respeitar o interstício de dois anos para a entrega dos certificados dos cursos de atualização e aperfeiçoamento realizados por instituições credenciadas, com carga horária mínima de 8 horas. São considerados como requisitos e exigências o atendimento aos critérios de avaliação de indicadores de crescimento de sua capacidade profissional, através da conclusão de cursos, embora não haja critérios objetivos explicitados para tal avaliação, com exceção do crivo pelo qual passam os cursos analisados preliminarmente pela Secretaria da Educação e pelo Conselho Municipal de Educação.

Para a obtenção da evolução por via não acadêmica ainda é necessário que o professor tenha cumprido, no mínimo, três anos de efetivo exercício, contados a partir da data de sua admissão, não tenha sofrido nenhuma sanção disciplinar prevista em lei e preencha os requisitos e as exigências previstas para o emprego público permanente, no nível da carreira.

Embora não tendo como foco específico a formação contínua, a evolução funcional pela avaliação do desempenho, realizada anualmente, tem prevista em seu bojo a análise do "interesse em aprimoramento profissional contínuo" como um de seus fatores.

A seção que trata das possibilidades de afastamento docente concede ao profissional do magistério a possibilidade de frequentar cursos de aperfeiçoamento e pós-graduação, mestrado e doutorado, pelo prazo máximo de dois anos, sendo concedido àqueles que optarem por frequentar os referidos cursos sem prejuízo da docência o afastamento de suas funções para a frequência dos dias exigidos durante o curso, desde que comprovada a assiduidade, sem prejuízo da remuneração.

Procuramos identificar, também, nas atribuições descritas para cada um dos cargos, a exemplo do que fizemos com os demais sistemas pesquisados, o que essas mesmas atribuições indicavam quanto à responsabilidade em garantir que os espaços ofertados para formação contínua fossem, de fato, aproveitados.

Nesse sentido, o que encontramos foi, de certa forma, surpreendente, considerando o tempo de jornada dedicado a essa função. Não há nenhuma referência à articulação do processo de formação contínua em nenhum dos cargos em comissão que, na prática, conduzem as políticas públicas de educação do município, no caso os diretores de departamento de educação infantil e fundamental e o supervisor educacional, estando presentes no rol de suas atribuições, basicamente, questões de ordem administrativa. 
O mesmo também é observado nas atribuições do diretor de escola, ficando a cargo do coordenador pedagógico praticamente toda a responsabilidade referente ao planejamento, acompanhamento e avaliação.

Vale ressaltar que não obtivemos acesso a outros tipos de diretrizes ou normas reguladoras dos processos de formação contínua ou a quaisquer outros aspectos como, por exemplo, o currículo.

\subsection{A proposta de Formação do Sistema C}

Dentre os três sistemas analisados é o que possui o maior conjunto de oportunidades e espaços de formação, garantidos pelo estatuto do magistério. São, no mínimo, cinco horas semanais destinadas aos momentos coletivos de formação.

Conforme nos relatou o gestor municipal, as cinco horas dedicadas à formação são organizadas mediante consulta prévia aos professores da rede e coletadas pelo coordenador da escola que, juntamente com outros coordenadores da rede e a equipe da secretaria de educação, faz a eleição dos temas a serem abordados durante o ano. Assim, a cada semana ou a cada quinze dias, os coordenadores se reúnem para estudar os textos e temas que vão para as escolas, onde o coordenador local pode acrescentar outros elementos que julgar necessários ao seu contexto.

As entrevistas revelam que, no ano de 2013, a formação oferecida aos professores constitui-se, unicamente, de duas ações de formação: a desenvolvida durante os HTPCs e o curso destinado aos professores alfabetizadores do $1^{\circ}$ ao $3^{\circ}$ ano, o PNAIC, disseminado pelos técnicos lotados na secretaria de educação do município. Através de relação de eventos de formação fornecida pela secretaria, detectamos, ainda, no ano de 2012, a realização de oito palestras, com temas bastante variados e genéricos, como "a importância do trabalho em equipe", "Valores/mudanças do século XX". Já as oficinas ocorridas nesse mesmo ano têm como público-alvo os professores da educação infantil abordando leitura, brincadeiras, oficinas de folclore, ditos populares e cantigas de roda de verso, além de outros como: modelagem em argila, brinquedos em tecido, artes plásticas e massagem para bebês.

A formação desenvolvida no município não contempla os diretores de escola, sendo que é na figura do coordenador que estão centradas as funções de formação e acompanhamento da mesma. 
As avaliações externas aparecem como determinantes no conjunto dos temas abordados na formação de professores. Segundo a coordenadora pedagógica, eles estão presentes o ano todo, mas o modo de abordagem não está claro, pois se apresenta de forma contraditória em relação aos objetivos da avaliação externa na formação contínua. Enquanto o gestor municipal descreve tais ações somente como reflexão sobre a sua importância, a coordenadora relata ações mais concretas, como a aplicação aos alunos de atividades semelhantes às cobradas nas provas.

Não é que é bem voltada. Como todos os anos nós participamos dessas avaliações externas, alguns HTPCs são direcionados pra reflexão do que são essas avaliações, então porque elas acontecem, até pra conscientizar o professor da importância dessas avaliações que vêm. Nos próprios HTPCs são feitas leituras de manuais didáticos, de aplicação de provas, até pra conduzir melhor o professor no momento da aplicação. Não algo bem direcionado às questões em si, mas assim âmbito maior, sobre o porquê que existem essas avaliações, pra conscientizar mesmo os nossos professores dessa necessidade de estar aplicando essas avaliações externas. (GMSC)

Então, a nossa atuação em relação às nossas formações está mais relacionada ao referencial de conteúdo que será abordado nas avaliações. Se bem que são conteúdos que já são trabalhados na prática, já fazem parte do currículo da criança, mas trabalhos mais voltados pros referenciais, que tipo de habilidade, que tipo de conteúdo que vai ser cobrado nessas avaliações, que tipo de questão que vai cair pra estar repassando isso pros alunos. Nós não treinamos, não ficamos só nisso. (...) Elas preparam atividades em cima desses referenciais que vem de provas anteriores, que a gente já vem trabalhando com as crianças. (CPSC)

Não foram descritas ações reflexivas que considerassem a realização de diagnóstico sobre as necessidades dos alunos, baseadas em avaliações anteriores, externas e internas e que estivesse fomentando o direcionamento das formações e consequentemente o trabalho dos professores em sala de aula.

O conjunto das propostas de formação pensada pelo Sistema C conduz a uma tendência bastante transmissiva, já que a relação teoria e prática parece apresentar-se de forma desarticulada. Denota-se, pela fala do gestor municipal, a existência de separação entre elas ao se referir ao desejo das professoras por atividades práticas e ao assumir que essa relação está presente apenas nas ações do PNAIC.

Todos os cursos que nós elaboramos aqui pela secretaria, sempre reservamos um tempo pra relato de experiência. Pra que essa 
experiência colocada em sala de aula seja mais um, digamos assim, um conteúdo a ser trabalhado nas nossas formações. Até pra comprovar que tudo que é feito na teoria, tudo que é falado na teoria pode ser aplicado na prática. Nós percebemos muito isso através do relato dos professores. Então, em toda a formação, além, da análise teórica, da leitura de textos, nós temos o momento do relato de experiências. Isso contribui muito com a gente, inclusive o PNAIC, sua sugere muito isso, a discussão, colocar em pauta toda a prática, toda a vivência delas, realizadas em sala. Então, assim, o que eu percebo, como formador do pacto agora, é que muito do que a gente está lendo, estudando na teoria é o que muitas já aplicam na prática. (GMSC)

Quando se refere à articulação entre teoria e prática, restringe-se a troca de experiências. Além disso, é preciso ressaltar a ausência de "outros cursos de formação" montados pela secretaria de educação.

Ao exemplificar de que modo a formação contempla no município as questões da prática, descreve a montagem de oficinas para a educação infantil, destacando o desejo das professoras desse segmento em participar de oficinas práticas.

(...) No planejamento de início de ano, quando elas colocam as questões das formações elas pedem muitas oficinas práticas, porque é o que elas encontram, é o que vem ao encontro das necessidades de sala de aula. Então nós trazemos todo ano: nós temos a nossa semana de expressão cultural, nós temos a nossa semana do bebê, em que trazemos formações, palestras de fora, de pessoas renomadas no assunto, mas sempre a cobrança delas é que sejam oficinas, pra prática mesmo, pra aprendizagem prática. (...) Então, nós trouxemos alguns palestrantes, as próprias unidades buscam palestrantes na nossa cidade, pessoas que trabalham no SOS pra ter uma fala, policiais militares, assistentes sociais. É uma fala de formação não tanto pro nosso profissional, mas pra sociedade, o público, porque sempre pensamos muito também nessa parceria da família com a comunidade. (GMSC)

Nesse sentido, apresenta como exemplo de "oficinas práticas" ações nas quais não se percebe de que forma as bases teóricas e conceituais foram articuladas com as ações descritas. A hipótese de que teoria e prática são abordadas de forma separada e hierarquizada se confirma na fala da coordenadora: "Temos formações teóricas, voltadas pra teoria e temos formações pra prática, relacionadas à metodologia”. Assim se posiciona sobre a questão:

É porque quando você estuda algum autor, você estuda assim uma linha, uma proposta pedagógica baseada em alguma linha de pensamento em algum autor, fica mais na teoria. Agora quando você parte mesmo pra focar a metodologia, você vem com o como ensinar. 
Então você não fica preso em pensamentos de autores, no que seria o ideal. Partimos pra prática mesmo. É o como ensinar, que tipo de objeto vou usar, que material eu vou usar, na utilização de um material concreto. (CPSC)

Não há na rede documentos que norteiem as ações de formação, estabelecendo diretrizes ou cronograma das atividades programadas para o ano. Segundo o gestor municipal, "elas vão acontecendo conforme a necessidade".

Quanto às formas de acompanhamento e avaliação, estas se restringem às impressões colhidas em relação à satisfação dos participantes e não foram descritos quaisquer mecanismos de acompanhamento de práticas de formação nas escolas.

Novamente reforçamos o fato de que não realizamos uma análise profunda da proposta de formação dessa rede, restringindo-nos às falas dos gestores municipais e aos documentos por eles fornecidos. No entanto, é possível perceber que, embora haja espaços criados para que a formação aconteça, a secretaria de educação apresenta-se com uma fraca atuação na organização de propostas de formação mais consistentes, especialmente no que se refere à atuação dos professores como protagonistas de seu processo de construção de saberes docentes.

\subsection{Representações sobre Formação Contínua}

\subsubsection{Representação sobre Formação Contínua pelos gestores municipais}

A partir das duas categorias de análise criadas - a formação contínua como meio de melhorar os resultados do sistema e a formação contínua como responsabilidade de outrem - passaremos a expor o observado em relação à manifestação dos três gestores entrevistados nos Sistema C.

\subsubsection{Representação de Formação Contínua como meio de melhorar os resultados do Sistema}

No Sistema C, os resultados do sistema de ensino, sobretudo aqueles observados pelas avaliações externas em nível estadual e federal, também se constituem como os principais impulsionadores das propostas de formação contínua, conforme identificamos nas manifestações do gestor municipal e da coordenadora pedagógica. 
O gestor municipal, responsável por expor as propostas de formação do município, entende a formação também como uma forma de "saber melhor como lidar com essas avaliações externas, SARESP, Prova Brasil”. Esclarece, conforme já observado, que a formação "não é bem voltada ( para as avaliações externas)", mas que o tema costuma ser abordado de forma ampla, focando mais os procedimentos de aplicação que propriamente os conteúdos das provas.

Seu discurso nos conduziria a pensar que a temática das avaliações externas pouco influenciaria os momentos de estudo coletivo nas escolas, representando apenas orientações quanto aos momentos de aplicação da prova e conscientização de sua importância. No entanto, a fala da coordenadora pedagógica entrevistada revela uma contínua presença do tema na pauta dos HTPCs.

A nossa atuação em relação às nossas formações está mais relacionada ao referencial de conteúdo que será abordado nas avaliações. Se bem que são conteúdos que já são trabalhados na prática, já fazem parte do currículo da criança, mas trabalhos mais voltados pros referenciais, que tipo de habilidade, que tipo de conteúdo que vai ser cobrado nessas avaliações, o tipo de questão que vai cair pra estar repassando isso pros alunos. A gente não treina, não ficamos só nisso. As professoras do quinto ano, em ano de prova Brasil, elas focam o trabalho delas de língua portuguesa e de matemática na prova Brasil, porém nesse trabalho elas abordam todo o conteúdo que elas tem que trabalhar com a classe.(...) Nós fazemos uma análise desse referencial, que tipo de conteúdo vai ser cobrado nessas avaliações, fazemos uma análise do tipo de atividade, quais as características das atividades. Elas preparam atividades em cima desses referenciais que vem de provas anteriores, que a gente já vem trabalhando com as crianças. (...). Grifo nosso. (CPSC)

A coordenadora ainda afirma que os estudos sobre a Prova Brasil pautaram as discussões coletivas durante todo o ano de 2013. Nesse sentido, ao considerarmos que a maioria dos estudos é direcionada pela Secretaria de Educação, parece evidenciar-se certa contradição entre as falas da coordenadora pedagógica e as do gestor municipal, no que se refere à frequência com que ocorre nos momentos de estudo. No entanto, a centralidade em relação aos resultados fica evidenciada nas representações dos dois sujeitos.

Ao que se pode depreender do tipo de trabalho desenvolvido nos HTPCs, que se constituem, como já analisado anteriormente, nos principais momentos de formação para esses professores, não identificamos nas ações descritas inovações que pudessem levar os docentes a mudarem sua prática em sala de aula, ainda que estas tivessem como 
tema as disciplinas de língua portuguesa e matemática. Ao contrário, tais propostas parecem pautar-se em informações sobre o tipo de questão da prova, a forma de abordagem do conteúdo e os procedimentos de aplicação dos testes, o que, a nosso ver, reforça a ideia de treino.

Os dois sujeitos parecem conceber as ações de formação como instrumentos importantes na melhoria dos resultados do sistema, no caso, os observados como resultado direto das avaliações externas. No entanto, tal preocupação não deflagra ações mais consistentes a fim de oferecer aos professores maiores oportunidades de crescimento profissional. Parecem entender que, para que os índices sejam melhores, bastam esclarecimentos sobre os mecanismos de funcionamento das avaliações externas, ideia essa reforçada pela fala evasiva e titubeante da diretora de escola. Ao ser solicitada que descrevesse de que forma acontece o preparo dos professores para as avaliações externas, assim esclareceu:

Estamos trabalhando o SARESP agora, junto com a diretoria de ensino. Nós tivemos reuniões na diretoria de ensino, tivemos reuniões na prefeitura e diante do que eles passam pra nós, nós desenvolvemos aqui na escola. É bem informativo e alivia um pouco a tensão, porque a gente fica tensa com essas avaliações. Tira e esclarece bem as dúvidas. Dá um direcionamento bem bacana pra nos deixar bem tranquilos. (GESC).

De maneira geral, as falas da diretora de escola durante a entrevista não nos permitiram que lhe atribuíssemos uma representação de formação contínua com foco nos resultados. No entanto, suas declarações em relação ao assunto reforçam o que parece estar ocorrendo no município quanto ao tipo de direcionamento das formações em relação a avaliação externa.

\subsubsection{Representação de formação contínua como responsabilidade de}

\section{outrem}

A análise das representações dos gestores tecida até o momento nos revelou um posicionamento em relação à formação contínua cujo foco, especialmente em relação ao gestor municipal e à coordenadora pedagógica, centra-se nos resultados do Sistema. Percebemos também que tal representação ao objetivar-se não se concretiza em inovações na área da formação de professores, já que a ideia de treino para as avaliações 
externas parece bastante fortalecida, especialmente em relação à coordenadora pedagógica.

Ao mesmo tempo, o que se percebe é que há uma tendência no Sistema de ensino em assumir de forma muito tímida a autoria das ações em âmbito municipal. Nesse sentido, a autonomia e autoria sobre o processo parece, no caso dos três gestores entrevistados, estar sendo transferida a terceiros.

No entanto, os discursos dos três gestores entrevistados conduzem para a criação de uma imagem de gestão da formação centrada em amplos processos de participação e autonomia, como se pode verificar na fala do gestor municipal.

E nesse planejamento são colocadas as expectativas dos professores em relação ao ano, tanto em relação à sala de aula, quanto à formação. Desenvolvimento de projetos em sala de aula e quais formações externas poderiam contribuir. (GMSC)

(...) a gente sente mais a necessidade do grupo. (GMSC)

(...) na nossa pauta de planejamento essa questão de dar liberdade pro profissional colocar em questão o que ele acha pertinente (...). (GMSC)

São mais oficinas do que palestras, porque isso é até um pedido delas. (...) (GMSC)

(...) eles (a comunidade) colocam também muitas questões que contribuem pra gente pensar nas formações de nossos professores. (GMSC)

Então nós temos unidades aqui, por exemplo, que são mais periféricas, então muitas vezes a formação direcionada pra esse profissional dessa unidade é diferente de uma formação direcionada a uma unidade mais centralizada, onde os objetivos e anseios da comunidade e até do profissional daquela unidade é outro. (GMSC)

Ao relatar a existência de participação dos professores e da comunidade, assim como a preocupação ao atendimento das especificidades locais das escolas mais afastadas, parece simular a existência da gestão democrática. Contraditoriamente, ao descrever de forma concreta as ações de formação, relata ações pensadas por terceiros, como é o caso do Pnaic, o único curso ocorrido no ano de 2013, cuja estrutura já se encontra formatada. Conforme relata

(...) quando vem um curso do governo federal, ela já vem praticamente com uma estrutura pronta. É só de aplicação, então corresponde a cada município aplicar esse curso. (GMSC) 
A responsabilidade sobre as principais decisões a respeito da condução das ações de formação profissional não parece claras para o gestor, que atribui constantemente a outras instâncias tal função. Na confrontação entre o vivido, descrito através de sua fala e o concebido, formulado a partir das ideias que possui sobre participação e autonomia parece revelar-se uma espécie de pudor em tomar para si a condução das políticas de formação em nível municipal.

A mesma tendência em transferir a responsabilização pela condução das decisões na área também pode ser verificada em relação ao posicionamento da coordenadora e da diretora de escola, ainda que se observem diferenças na maneira como compreendem suas funções específicas.

A coordenadora pedagógica, a quem também atribuímos a representação de formação contínua como meio de melhorar os resultados nas avaliações externas, mostra-se na maior parte do tempo como uma "executora" de propostas, cuja função se centraria na tarefa de repassar a formação pensada pela secretaria de educação, através das coordenadoras de área de educação infantil e ensino fundamental. É o que se infere de suas falas.

Tem formações que são específicas pras coordenadoras, que é pra nós passarmos para os professores. Então, é feito primeiro uma formulação com a gente e depois a gente vem e multiplica com os professores (...). (CPSC)

Embora ressalte a autonomia dada pela secretaria de educação, para que outras ações pensadas pelas escolas possam ocorrer, não se percebe de forma concreta a existência de alguma inovação pensada pela equipe da escola.

Em relação à diretora de escola entrevistada não conseguimos atribuir-lhe representação de formação contínua com foco nos resultados, uma vez que pouco mostrou seu posicionamento pessoal em relação ao tema.

Sua fala breve pautou-se num discurso genérico, baseado em elementos do senso comum, com argumentos ainda mais abstratos que os observados em relação aos outros dois gestores do município. $\mathrm{O}$ teor e entonação de sua fala não nos sugeriram comprometimento profissional em relação ao tema tratado. Ao se manifestar, não demonstrou entender a formação contínua desenvolvida em sua unidade como uma tarefa inerente a sua função. Tal posicionamento pode ser ilustrado na seguinte fala dessa diretora de escola. 
Olha, a gente participa com a reunião de coordenador, de diretor lá embaixo (na secretaria). Eles sugerem cursos pra gente, principalmente pra coordenação que participa mais ativamente junto com os professores em HTPC. Recebemos as coordenadas de como vai ser, as sugestões do que a achamos necessário pros professores, pra eles articularem um curso bem bacana e, diante dessa pesquisa, eles buscam pra gente, a gente passa pro professor e muitas vezes a coordenadora mesmo diante da nossa realidade, elas procuram textos pra formar os professores diante de nossa dificuldade. (GESC)

A diretora de escola parece revelar uma crença de que cabe à coordenadora pedagógica a função de formar os professores, devendo principalmente repassar as orientações advindas da secretaria de educação.

Eu acredito que a secretaria num todo vê as dificuldades de todas as escolas e procura um curso que atenda à demanda de todos, mas nós temos autonomia de ver a nossa dificuldade e buscar entre nós e a gente estuda em HTPC, através da coordenação. (GESC)

$\mathrm{Na}$ mesma perspectiva, o discurso sobre a possibilidade do exercício da autonomia se faz presente. No entanto, a diretora parece isentar-se, seja como "autora" ou "executora", de uma atuação mais presente no conjunto das ações de formação de sua unidade.

Como já explicitado, a ausência de ações mais inovadoras, assim como o fato de estarem ausentes exemplos de posições mais autônomas por parte desses gestores entrevistados nos levam a considerar que possuem um entendimento de que a função de inovar na área de formação de professores não lhes cabe, fazendo com que atuem como coadjuvantes no processo, comprometendo-se pouco com mudanças mais efetivas.

\subsubsection{Representação de formação contínua pelos professores da rede}

Enviamos aos professores do ensino fundamental do Sistema C 146 questionários, dos quais 85 retornaram. A devolutiva de $58 \%$ dos questionários configurou o menor percentual dos três sistemas de ensino.

A exemplo dos dois Sistemas de ensino estudados, traçamos, com base na análise da primeira seção de perguntas, um breve perfil dos professores do Sistema C. Dos professores que responderam ao questionário, 95\% declararam ser efetivos, sendo que $50 \%$ deles afirmaram trabalhar em outra unidade, e desse percentual, $93 \%$ em outra 
escola pública, o que nos leva a considerar facilidades para o acúmulo de cargo no Sistema.

Quanto à formação, 89\% declararam possuir magistério em nível médio e 95\% afirmaram possuir pedagogia. Dentre os que possuem pedagogia, $47 \%$ ainda declararam possuir outra licenciatura. Com relação à formação em nível de pós-graduação, $62 \%$ afirmaram possuir este nível de formação.

Passaremos a expor, a partir de agora, a análise das manifestações obtidas por esse instrumento - 1. Fatores que mais motivam a participação na formação contínua; 2. Expectativas sobre formação contínua e sua relevância para a prática.

\subsubsection{Fatores que motivam a participação na Formação Contínua}

Com o objetivo de identificar as motivações dos professores sobre sua participação na formação contínua, procuramos abordar esse aspecto através da análise do que foi espontaneamente apontado pelos professores como motivação para a participação e através de questões diretas sobre seu posicionamento em relação à ligação entre formação contínua e valorização na carreira. Analisamos, ainda, suas respostas quanto à frequência nos cursos oferecidos e as informações sobre sua formação em nível de pós-graduação.

Apresentamos, na tabela a seguir, os principais fatores apontados pelos professores sobre o que motivaria sua participação em cursos de formação continuada.

\section{Tabela 16 - Fatores que mais motivam a participação nos cursos oferecidos ${ }^{32}$}

\begin{tabular}{|c|c|}
\hline Motivação para participação & Sistema C $^{\mathbf{3 3}}$ \\
\hline Atualização/Novos conhecimentos & $49,5 \%$ \\
\hline Aprimoramento da Prática & $19 \%$ \\
\hline Progredir na carreira/obter certificação & $9,5 \%$ \\
\hline Socialização/ Reflexão sobre a prática & $8,5 \%$ \\
\hline Melhorar profissionalmente & $8,5 \%$ \\
\hline Relevância/qualidade do curso & $5 \%$ \\
\hline
\end{tabular}

\footnotetext{
${ }^{32}$ As porcentagens da tabela referem-se ao conjunto das manifestações dos professores sistema pesquisado.

${ }^{33} 85$ professores e 95 manifestações
} 
A tabela acima sintetiza os dados relativos ao conjunto das principais motivações apontadas pelos professores para a participação em cursos de formação contínua.

Conforme se nota, $49 \%$ dos professores que apontam como principal motivador de participação na formação contínua o fator "Atualização/Novos conhecimentos" e $8,5 \%$, "melhorar profissionalmente". Somados, os dois fatores representam 57,5\%, ou seja, mais da metade dos motivos manifestos, chamando-nos a atenção o "não dito", já que a ideia de fazer cursos em busca de atualização e novos conhecimentos, assim como a de fazer cursos para melhorar profissionalmente, pode estar ligadas a fatores muito variados, não revelando, a princípio, as reais motivações para a participação. Em outras palavras, o tom genérico dado ao eleger a atualização e aquisição de novos conhecimentos, bem como melhorar profissionalmente, pode incluir outras motivações não manifestadas.

Dessa forma, as manifestações que apontam de maneira mais concreta os principais motivadores de participação são as voltadas à prática pedagógica como "aprimoramento da prática", "socialização/reflexão sobre a prática" e "relevância dos cursos", somando apenas $32,5 \%$, e os que apontam os fatores ligados à obtenção de benefícios na carreira são 9,5\%.

Diante dos dados, o que se nota é que, dentre as manifestações dos professores que responderam ao questionário, apenas $32,5 \%$ parecem reconhecer de forma segura a formação contínua como instrumento de interferência nas questões da prática.

Ao perguntarmos aos professores do Sistema C se consideram importante que a formação traga valorização profissional, através de benefícios na carreira, todos os professores da rede concordaram, mas $81 \%$ dos professores que responderam ao questionário aceitariam participar mesmo sem o benefício, e $12 \%$ não participaria caso a formação não produzisse tais benefícios.

Apenas um dos professores do Sistema se manifestou para além da questão. Segundo ele, sua participação se deve ao entusiasmo pelos alunos. $7 \%$ dos professores que responderam à pergunta colocam condições para a participação, como o horário do curso ou sua relevância.

Quanto à frequência de participação nos cursos de formação oferecidos pelo município, $63 \%$ dos professores afirmam participar "sempre” e 33\% "às vezes". Um dos professores que afirmaram participar "sempre" esclarece: "sempre que tem". Há, ainda, 
outra declaração dentre os que afirmaram não participar "nunca": "o município não oferece formação". 3,5\% dos professores deixaram de responder a esta questão.

Os benefícios para a carreira, considerando a possibilidade de progressão acadêmica, indicam uma possível interferência na quantidade de professores que possui este nível de formação, conforme mostra o quadro abaixo.

\section{Tabela 17 - Percentuais de formação em nível de pós-graduação manifestos pelos professores}

\begin{tabular}{|c|c|}
\hline Possui curso de pós-graduação? & Sistema C \\
\hline Lato Sensu & $62 \%$ \\
\hline $\begin{array}{c}\text { Stricto Sensu } \\
\text { (mestrado) }\end{array}$ & $0 \%$ \\
\hline Total & $62 \%$ \\
\hline
\end{tabular}

Apesar do percentual significativo de professores com formação em nível de pós-graduação, nenhum dos professores que responderam à pesquisa informou possuir formação em nível de mestrado ou doutorado, apesar da existência de incentivos, como progressões salariais e afastamento com remuneração.

A análise dos principais motivadores de participação na formação nos revelou um Sistema de ensino cujos professores pouco revelam ou o fazem de maneira pouco incisiva ao se manifestarem sobre os motivos que os impulsionam a se capacitar continuamente, já que chama atenção o percentual de manifestações que pouco esclarece sobre esse aspecto.

Ao mesmo tempo em que se verifica um percentual de professores que focam suas motivações na prática pedagógica, não se pode deixar de ressaltar que há também aqueles que encontram motivação apenas pelos benefícios salariais, uma vez que, nesse contexto, a legislação municipal favorece este aspecto. 


\subsubsection{Expectativas sobre a Formação Contínua e sua relevância para a prática}

As questões que compuseram esta categoria de análise tiveram como objetivo desvelar representações sobre formação contínua, considerando a manifestação dos professores em relação às suas expectativas quanto ao formato de cursos, áreas do conteúdo a serem contempladas e relevância desses cursos de formação para a prática pedagógica.

A primeira questão dessa categoria de análise focava a avaliação que os professores fazem dos cursos de formação oferecidos, tendo três alternativas como opção: 1. São muito teóricos e não se relacionam com a realidade da escola; 2. Apresentam apenas receitas prontas, sem explicar o porquê das coisas; 3 . Outra.

De maneira geral verifica-se certo equilíbrio entre os aspectos classificados como positivos e negativos, mas chama a atenção o percentual de $17 \%$ de professores que não responderam à questão.

Dos $45 \%$ que classificamos como avaliação negativa, 39\% optaram pela alternativa que aponta para o fato de os cursos serem muito teóricos. Desses, apenas $2 \%$ optaram pela alternativa "Apresentam apenas receitas prontas, sem explicar o porquê das coisas" e 4\% estabeleceram as seguintes críticas: "a abordagem é superficial”, "deve haver mais equilíbrio entre teoria e prática", "são teóricos, se relacionam com a prática, mas pouco enriquecem”.

Dos apontamentos que classificamos como avaliação positiva, 18\% acreditam que os cursos são bons e contribuem, $21 \%$ afirmam que os cursos são teóricos, mas se relacionam com a realidade da escola e $10 \%$ apontam para a existência de cursos que apresentam "teorias e práticas".

Sobre o formato ideal de cursos de formação apontados pelos professores, evidencia-se o desejo por cursos que contemplem a realidade da escola e a articulação entre teoria e prática.

Nesse sentido, é possível perceber que $47 \%$ parecem preferir cursos que ofereçam subsídios para o enfrentamento dos desafios pedagógicos. Desse total, 20\% apontam para a articulação entre teoria e prática, justificando a escolha com as seguintes afirmações: "Para que possa ser aproveitada", "Para vivenciar a teoria”, "Só a teoria não adianta”. Embora apontem para a articulação entre teoria e prática, parece haver nas justificativas uma tentativa de reafirmar a necessidade de experiências práticas. Tal desejo evidencia-se na manifestação "cursos práticos com pouca teoria”, representando 
também 20\% das manifestações que se apresentaram sem justificativas de escolha. O mesmo também parece ocorrer em relação aos $7 \%$ das manifestações que indicaram para cursos que deem conta da realidade vivida com os alunos. De qualquer sorte, consideramos bastante significativo o percentual de manifestações que sinalizam para a preferência por cursos voltados para a realidade de sala de aula.

Observa-se também no Sistema C um percentual de manifestações que fazem a opção pelo formato ideal de curso, considerando em primeiro lugar sua organização prática. Esse percentual é de $18 \%$, e as justificativas voltam-se para as questões do diaa-dia e para a organização do tempo do professor.

Houve, ainda, 25\% das manifestações que indicam preferência por "cursos presenciais", "em módulos de curta duração" e "com bons profissionais". No entanto, apenas uma explicação foi dada para a opção "em módulos de curta duração", em que uma das professoras diz ser este o melhor formato para "não perder o que fez".

Dentre os $7 \%$ das manifestações sem qualquer justificativa, encontra-se aquela que indica o PNAIC como formato ideal.

Embora os números não se apresentem de forma tão distinta dos demais sistemas estudados, o que se percebe é que, de modo geral, os professores se manifestam de modo aparentemente superficial, justificando-se pouco em relação ao tema perguntado.

Quanto aos temas a serem abordados durante as formações, assim se manifestaram: 


\section{Tabela 18: Principais temas/áreas apontadas para a abordagem na formação contínua}

\begin{tabular}{|c|c|}
\hline Tema/área & Percentual de respostas $^{\mathbf{3 4}}$ \\
\hline $\begin{array}{c}\text { Dificuldade de } \\
\text { aprendizagem/Inclusão/AEE }\end{array}$ & $25 \%$ \\
\hline Alfabetização e Letramento & $19 \%$ \\
\hline Matemática & $18 \%$ \\
\hline Todas as áreas & $9 \%$ \\
\hline Gestão de sala de aula/ Indisciplina/ \\
Desinteresse do educando e das famílias
\end{tabular}

Como se vê na tabela acima, $25 \%$ das manifestações apontam a preferência por temas voltados para as dificuldades de aprendizagem e inclusão. Assim como nos demais sistemas também se destacam as áreas de alfabetização e matemática, mas, no caso do Sistema C, a área de Língua Portuguesa aparece com apenas 5\% das manifestações. Somados, os temas voltados às dificuldades de aprendizagem, língua portuguesa e alfabetização e matemática têm $62 \%$ das manifestações, ficando os demais pulverizados em outros temas e áreas do conhecimento.

Sobre a relevância da formação para o enfrentamento dos desafios pedagógicos enfrentados pelos professores, uma maioria significativa considera determinante o trabalho que se faz, individual ou coletivamente, na escola. É o que se pode observar na tabela abaixo.

\footnotetext{
${ }^{34} 131$ declarações.

${ }^{35}$ Atendimento Educacional Especializado
} 
Tabela 19: Relevância da formação no enfrentamento dos desafios pedagógicos

\begin{tabular}{|c|c|c|c|}
\hline $\begin{array}{c}\text { O trabalho } \\
\text { individual e } \\
\text { coletivo da escola }\end{array}$ & $\begin{array}{c}\text { A ajuda externa } \\
\text { possibilitada } \\
\text { pelos cursos }\end{array}$ & \multicolumn{2}{|c}{ Outra } \\
\hline \multirow{3}{*}{$80 \%$} & \multirow{3}{*}{$4 \%$} & Os dois & $12 \%$ \\
\cline { 3 - 4 } & & Não respondeu & $2 \%$ \\
\cline { 3 - 4 } & & Formação de Qualidade & $1 \%$ \\
\cline { 3 - 4 } & & Interação com os pais & $1 \%$ \\
\hline
\end{tabular}

Apenas 4\% atribuíram exclusivamente tal relevância à ajuda externa possibilitada pelos cursos e $12 \%$ consideram os dois fatores como importantes. Como se nota, só $2 \%$ dos professores indicaram outros fatores.

Nesse mesmo sentido, ao tentarmos articular a ideia de aquisição de conhecimentos baseados na prática educativa aliada aos cursos de formação, também perguntamos aos professores a quais fatores atribuíam seus atuais conhecimentos pedagógicos. Como se pode notar, uma significativa maioria $(78 \%)$ atribuiu seus saberes à prática e aos cursos realizados, sendo muito baixo (1\%) o percentual de professores que atribuíram seus conhecimentos pedagógicos unicamente ao curso de graduação realizado.

Tabela 20: Principais contribuições à construção de conhecimentos pedagógicos

\begin{tabular}{|c|c|l|c|}
\hline $\begin{array}{c}\text { A minha prática e aos } \\
\text { cursos realizados }\end{array}$ & $\begin{array}{c}\text { Ao meu curso de } \\
\text { graduação }\end{array}$ & \multicolumn{2}{|c|}{ Outra } \\
\hline \multirow{2}{*}{$78 \%$} & \multirow{2}{*}{$1 \%$} & As duas opções & $20 \%$ \\
\cline { 3 - 4 } & & $\begin{array}{l}\text { Formação Contínua na } \\
\text { rede Estadual }\end{array}$ & $1 \%$ \\
\cline { 3 - 4 } & & Estudo em casa/Leituras & $1 \%$ \\
\cline { 3 - 4 } & & Prazer por aprender & $1 \%$ \\
\hline
\end{tabular}


No entanto, é importante destacar que $20 \%$ dos professores que responderam ao questionário consideram as duas opções.

O que se nota quanto às expectativas em relação à formação contínua é um forte desejo de que a formação contínua se volte para as necessidades da escola e para o enfrentamento dos desafios percebidos por estes professores.

Nesse sentido, o conjunto das manifestações sobre a avaliação e a expectativa em relação à formação contínua sugere a existência de certa insatisfação por parte de uma parcela dos professores, notando-se um cenário que parece estar inserido numa atmosfera de apatia, em que os professores demonstram pouco entusiasmo ao se referir à formação. São poucos os professores que se manifestaram para além das questões propostas. Ao mesmo tempo, a ausência de um clima mais motivado e engajado é notada mesmo dentre aqueles que se manifestaram positivamente em relação às ações de formação.

\subsection{Um cenário incerto, marcado por contradições}

A análise do conjunto dos elementos que compõe o contexto educacional do Sistema C desvelou-nos um cenário de contradições marcantes, ainda que as manifestações de professores e gestores tenham se apresentado de forma um pouco nebulosa, impondo desafios para o alcance de suas representações.

Verificou-se que, embora a legislação municipal apresente ótimos espaços de formação, garantidos através das cinco horas semanais de estudo coletivo e das oportunidades de valorização salarial em decorrência da participação nas formações contínuas, encontramos um conjunto de propostas de formação aparentemente frágil, se considerarmos os processos de planejamento, acompanhamento e envolvimento dos agentes responsáveis por sua promoção. Soma-se a isso a ausência de um clima mais motivado ao se estabelecerem vínculos entre formação e prática pedagógica, revelado através da manifestação de gestores e professores.

Dentre as fragilidades observadas nas propostas de formação voltadas aos professores do ensino fundamental, destaca-se seu caráter transmissivo, focado em resultados cujas ações pautam-se em orientações centrais incorporadas de maneira acrítica pelas unidades. Além disso, nota-se que é na figura do coordenador pedagógico que está inteiramente centrada a tarefa de promover formação docente, não se 
percebendo a presença de diretor da escola como uma figura de importância no processo.

Infere-se uma fraca articulação entre teoria e prática durante as cinco horas semanais de estudo coletivo. No entanto, essa mesma articulação é destacada como um ponto forte do Pnaic, único curso promovido pela secretaria de educação no ano de 2013 e apontado por alguns professores como modelo ideal de formação. O que se sugere é que tal relação parece estar restrita exclusivamente ao curso, uma vez que as falas dos gestores não demonstraram de maneira clara a existência da promoção de práticas reflexivas nas outras ações de formação do Sistema, sinalizando mais a hierarquização que a articulação entre a teoria e a prática.

O amplo processo de participação relatado para a eleição dos temas a serem trabalhados durante a formação também não condizem com as ações descritas, devido à escassez de cursos promovidos pela secretaria de educação e pela fraca diversidade de temas abordados. Nesse sentido, não foram destacados pelos gestores entrevistados outros temas como os apontados dentre as expectativas de formação, como é o caso de cursos voltados para a área da inclusão, por exemplo.

As entrevistas realizadas com os gestores nos revelaram uma representação de formação contínua com foco nos resultados das avaliações externas por parte do gestor municipal e da coordenadora pedagógica. No entanto, não detectamos, a partir delas, ações mais inovadoras. O que percebemos é que tais representações parecem objetivarse, concretizar-se em ações que pouco contribuem para a aprendizagem dos alunos, como é o caso do "treino para as provas", que parece ocorrer como reflexo de tais representações.

Ao mesmo tempo, esses mesmos gestores, assim como a diretora de escola entrevistada, pouco parecem sentir a urgência em suplantar o real, como sinaliza Lefebvre, propondo a utopia, criando um não-lugar. Neste sentido a ideia de produto sobrepõe-se à de obra, já que as ações descritas pautam-se na repetição, ausência de autoria e autonomia e na isenção da responsabilidade de inovar.

A análise das manifestações dos professores nos revelou um clima um tanto apático, pouco revelando sobre a forma de sentir e fazer em relação às temáticas de formação contínua abordadas pelo questionário. Como vimos, 57,5\% das manifestações indicam razões genéricas e imprecisas como motivadores e 9,5 encontram nos benefícios da carreira tais razões. 
Ao mesmo tempo em que se observam apenas 32\% das manifestações vinculando formação e prática pedagógica como motivação, é significativo o percentual de $47 \%$ das manifestações indicando preferência por formatos de curso de formação que enfatizem as questões da prática pedagógica.

Ainda que pouco revelem a partir das justificativas imprecisas apresentadas ao responder às diversas questões propostas pelo questionário é possível arriscar que os professores desse Sistema de ensino tendem a reconhecer na prática pedagógica o foco central das ações de formação, apontando a unidade escolar como lócus privilegiado para tais ações, embora demonstrem isso de forma tímida e pouco motivada.

Ao encerrarmos essa parte de nossa reflexão sobre o conjunto de elementos observados no Sistema C, ainda questionaríamos em que medida uma postura mais ciente da responsabilidade de inovar por parte dos gestores fomentaria uma melhor utilização dos ótimos espaços de formação presentes no município e a existência de um grupo de professores mais consciente da importância desempenhada pelos bons processos de formação contínua na vida das instituições escolares. 


\section{TRÊS SISTEMAS: SINGULARIDADES, REGULARIDADES E ALGUNS CAMINHOS}

É cierto que la desesperación, momento de la acción poietica, difere de la angustia, ese vacio del cual no se sale. Quienes rechazan el resgo porque no quierem sufrir ya no quieren la alegria.

\section{Henry Lefebvre}

Ao longo deste capítulo, descrevemos e analisamos o conjunto das principais ações no campo da formação profissional desenvolvidas nos três sistemas de ensino estudados, considerando, além das manifestações de gestores e professores em relação ao tema, os aspectos legais e estruturais que compõem o cenário específico de cada um deles.

Procuramos sintetizar no quadro abaixo os aspectos que consideramos importantes para uma análise comparativa entre os três Sistemas, já que, ainda que de maneira sucinta, tais informações ajudam a compor o panorama de formação existente em cada um dos sistemas municipais. 


\section{Quadro 13: PRINCIPAIS ASPECTOS DE INTERFERÊNCIA NA FORMAÇÃO PROFISSIONAL NOS SISTEMAS A, B e C}

\begin{tabular}{|c|c|c|c|}
\hline & SISTEMA A & SISTEMA B & SISTEMA C \\
\hline \multicolumn{4}{|c|}{ A LEGISLAÇÃO MUNICIPAL E A FORMAÇÃO CONTÍNUA } \\
\hline \begin{tabular}{lll} 
Horas & de & \multicolumn{2}{c}{ Trabalho } \\
Coletivo & na & jornada de \\
trabalho & & \\
\end{tabular} & Média de quatro horas & Duas horas & Cinco horas \\
\hline $\begin{array}{lll}\text { Progressão funcional via } \\
\text { acadêmica no plano de } \\
\text { carreira }\end{array}$ & Contemplado & Não contemplado & Contemplado \\
\hline $\begin{array}{l}\text { Progressão funcional via } \\
\text { não acadêmica por entrega } \\
\text { de certificados }\end{array}$ & Contemplada & Não contemplada & Contemplada \\
\hline $\begin{array}{l}\text { Afastamentos e licenças } \\
\text { para formação }\end{array}$ & Contemplado & Não contemplado & Contemplado \\
\hline \multicolumn{4}{|c|}{ ESTRUTURA E PRÁTICAS DE FORMAÇÃO } \\
\hline $\begin{array}{l}\text { Estrutura organizacional } \\
\text { da Secretaria de } \\
\text { Educação com finalidade } \\
\text { de promover formação } \\
\text { contínua }\end{array}$ & $\begin{array}{l}\text { Departamento destinado } \\
\text { exclusivamente } \\
\text { formação contínua, com } \\
\text { cargos e formas de } \\
\text { provimento previstos em } \\
\text { lei. }\end{array}$ & $\begin{array}{l}\text { Equipe de trabalho para a } \\
\text { formação contínua atuante } \\
\text { com estrutura } \\
\text { improvisada e adaptada. }\end{array}$ & $\begin{array}{l}\text { Equipe atuante na } \\
\text { formação contínua, cujos } \\
\text { cargos em comissão não } \\
\text { preveem, oficialmente, } \\
\text { tais atribuições. }\end{array}$ \\
\hline $\begin{array}{lll}\begin{array}{l}\text { Diretrizes } \\
\text { formação }\end{array} & \text { oficiais } & \text { de } \\
\end{array}$ & Possui & Não possui & Não possui \\
\hline Práticas de formação & $\begin{array}{l}\text { Poucos cursos oferecidos e } \\
\text { organizados pela } \\
\text { secretaria. Repasse de dois } \\
\text { cursos - PNAIC e Ler e } \\
\text { Escrever - no ano de } 2012 \\
\text { e } 2013 \text {. }\end{array}$ & $\begin{array}{l}\text { Ampla oferta de cursos e } \\
\text { oficinas organizados pela } \\
\text { secretaria de educação, } \\
\text { por parceiros contratados e } \\
\text { em parceria com } \\
\text { Universidade e outras } \\
\text { esferas governamentais. }\end{array}$ & $\begin{array}{l}\text { Pouca oferta de cursos e } \\
\text { oficinas. Predominam } \\
\text { ações em parceria com } \\
\text { outras esferas } \\
\text { governamentais, como a } \\
\text { realização do PNAIC. }\end{array}$ \\
\hline $\begin{array}{l}\text { Orientações r centrais } \\
\text { para os momentos } \\
\text { coletivos de formação }\end{array}$ & $\begin{array}{l}\text { Ocorrem basicamente } \\
\text { através das orientações do } \\
\text { programa Ler e Escrever, } \\
\text { organizado pela secretaria } \\
\text { de educação junto aos } \\
\text { coordenadores } \\
\text { pedagógicos. }\end{array}$ & 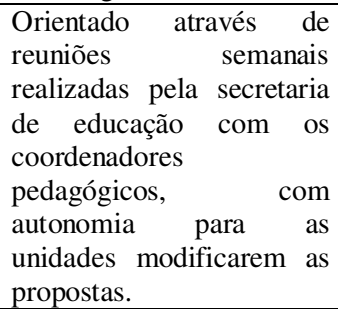 & 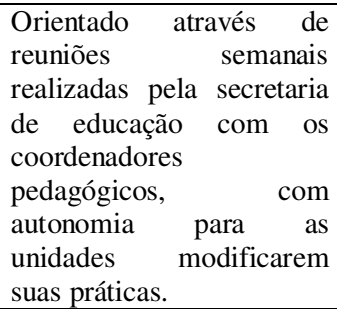 \\
\hline \multicolumn{4}{|c|}{ IDEB } \\
\hline Desempenho & $\begin{array}{l}\text { Crescimento sensível, sem } \\
\text { alcance das metas. }\end{array}$ & $\begin{array}{l}\text { Crescimento sustentado } \\
\text { com alcance das metas. }\end{array}$ & $\begin{array}{c}\text { Crescimento com } \\
\text { oscilações e alcance de } \\
\text { metas. }\end{array}$ \\
\hline $\begin{array}{l}\text { Interferência na } \\
\text { formação contínua }\end{array}$ & $\begin{array}{l}\text { Não direciona ações de } \\
\text { formação. }\end{array}$ & $\begin{array}{l}\text { Direciona ações de } \\
\text { formação. }\end{array}$ & $\begin{array}{l}\text { Direciona ações de } \\
\text { formação. }\end{array}$ \\
\hline \multicolumn{4}{|c|}{ REPRESENTAÇÕES } \\
\hline Gestores & $\begin{array}{l}\text { Tendência em repassar a } \\
\text { outros as principais } \\
\text { decisões sobre formação } \\
\text { contínua no município. } \\
\text { Formação contínua como } \\
\text { responsabilidade de } \\
\text { outrem. }\end{array}$ & $\begin{array}{l}\text { Formação contínua como } \\
\text { forma de melhorar os } \\
\text { resultados do Sistema, no } \\
\text { caso da gestora municipal } \\
\text { e diretora de escola. } \\
\text { Coordenadora pedagógica } \\
\text { tende a repassar as } \\
\text { responsabilidades pela } \\
\text { inovação no campo da } \\
\text { formação. }\end{array}$ & $\begin{array}{l}\text { Formação contínua como } \\
\text { meio de melhorar os } \\
\text { resultados do Sistema, no } \\
\text { caso do gestor municipal e } \\
\text { da coordenadora } \\
\text { pedagógica, que, assim } \\
\text { como a Diretora de } \\
\text { escola, demonstram pouca } \\
\text { autonomia na condução } \\
\text { das propostas de } \\
\text { formação. }\end{array}$ \\
\hline Professores & $\begin{array}{l}\text { Motivações e expectativas } \\
\text { sobre formação contínua } \\
\text { com tendência de ligação } \\
\text { aos benefícios na carreira. }\end{array}$ & $\begin{array}{l}\text { Motivações e expectativas } \\
\text { sobre formação contínua } \\
\text { mais ligadas à pratica } \\
\text { pedagógica. }\end{array}$ & $\begin{array}{l}\text { Motivações e expectativas } \\
\text { pouco manifestas, com } \\
\text { indícios de ligação com a } \\
\text { prática pedagógica. }\end{array}$ \\
\hline
\end{tabular}


Conforme descrito ao longo dos capítulos anteriores, cuja síntese das principais informações se apresenta no quadro acima, evidenciaram-se realidades distintas no que concerne aos modelos de estruturação das carreiras, às configurações das propostas de formação contínua e à estrutura de formação observada nas referidas secretarias de educação. A análise do referido conjunto nos permitiu perceber que os bons espaços de formação verificados nos Sistemas A e C, constituídos por horas da jornada de trabalho destinadas à formação, bem como pelas vantagens obtidas em decorrência da participação em cursos de formação, dentre outros fatores citados, encontram-se subaproveitados, uma vez que as condições existentes proporcionariam, em tese, boas oportunidades para o desenvolvimento de propostas de formação mais autônomas do que as observadas.

No Sistema A, a escassez de propostas de formação organizadas pela secretaria de educação evidencia-se, não sendo percebida a autonomia do Sistema, nem o envolvimento dos sujeitos responsáveis na construção de um projeto de formação para o município. No Sistema C, ainda que se observe uma presença sensivelmente mais marcante na condução de seus projetos de formação, estes se caracterizam pela dispersão e fragmentação, evidenciando-se nas falas dos gestores certa falta de clareza em relação ao que se pretende com a formação desenvolvida.

Por outro lado, a ausência de oportunidades semelhantes às verificadas nos Sistemas A e C não parece oferecer aos gestores do Sistema B obstáculos intransponíveis para uma formulação mais autônoma, em maior quantidade e qualidade que os demais. A inexistência de espaços semelhantes parece não impedir ao Sistema a ampla oferta de cursos e oficinas, sendo percebida, ainda que pontuais, a ocorrência de posturas e propostas inovadoras.

A análise das propostas de formação profissional, analisadas principalmente a partir do relato dos gestores dos três Sistemas de ensino, proporcionou-nos o conhecimento de um nível de realidade específico, formulado em grande parte a partir da fala dos entrevistados. A partir de nosso ângulo de observação, não constatamos, com exceção de alguns aspectos pontuais detectados particularmente no Sistema B, ações mais sistematizadas de acompanhamento e processos de avaliação de seus programas no sentido que nos propõem Davis, Nunes e Almeida (2011). Segundo os autores, para que o desenvolvimento profissional se efetive, é necessário 
Avaliar os resultados dos programas de Formação Continuada e, portanto, sua qualidade, por meio da apropriação, por parte dos professores, dos conteúdos e das habilidades neles oferecidos, sempre diversificando as modalidades de avaliação. Para evitar que a avaliação dos programas de Formação Continuada de professores centre-se basicamente nos resultados obtidos pelos alunos em avaliações censitárias, é especialmente importante variar estratégias. Observar a atuação docente em sala de aula, visitar as escolas de forma sistemática para discutir a prática pedagógica e os problemas enfrentados pelos docentes, coadunar esforços entre equipes centrais e equipes escolares etc., que são ricas fontes de informação sobre a qualidade das ações de Formação Continuada e sobre a implementação de mudanças nas práticas pedagógicas. O emprego de modalidades qualitativas de avaliação das ações de Formação Continuada e de acompanhamento de seus resultados pode e deve incorporar, inclusive, a participação das próprias equipes escolares, servindo como mais uma ação formativa (DAVIS, NUNES e ALMEIDA, 2011, p. 107).

Não entendemos que os municípios possuiriam as condições técnicas e estruturais para a realização de avaliações de impacto, cujo rigor metodológico necessário imporia desafios às secretarias. No entanto, concordamos com Davis, Nunes e Almeida (2011) sobre a necessidade de olhar mais atentamente para os processos de formação e suas consequências para a prática docente a partir da realização de procedimentos de acompanhamento construídos coletiva e colaborativamente, fornecendo aos profissionais que atuam como formadores no interior das escolas o desenvolvimento de habilidades profissionais.

As manifestações de gestores e professores, apreendidas através de questionários e entrevistas, nos permitiram alcançar as suas representações sobre formação contínua. Tais representações que surgem a partir de um trabalho de elaboração mental desses sujeitos, apoiam-se, dentre outras variáveis, no concebido, ou seja, no conhecimento por eles formulado. Segundo Lefebvre, as representações correspondem ao resultado do trabalho em que o sujeito formula suas concepções e as expressa (LEFEBVRE, 1983). Conforme aponta, tais representações são constituídas a partir das explicações originadas no cotidiano em meio a interações sociais. Neste ato comunicativo entre sujeito e objeto-mundo são produzidos símbolos com a capacidade de atribuir significados às coisas, através da linguagem.

Reconhecemos que as representações sobre formação contínua desses profissionais são constituídas pelos saberes acadêmicos da área, pelas opiniões e valores culturais e por inúmeros outros fatores presentes no cotidiano, incluindo as experiências 
de formação vividas em cada uma das realidades específicas, conforme aponta Penin (1995, p.8):

\begin{abstract}
Muitas das coisas existentes no real só são percebidas depois de conceituadas e nomeadas (...) e que a escola cria ou produz, ela própria, um saber específico, considerando, de um lado, a confrontação entre os conhecimentos sistematizados disponíveis na cultura geral, e de outro, aqueles menos elaborados, provenientes da lógica institucional quanto das características da profissão, como ainda da vida cotidiana escolar.
\end{abstract}

A análise dos depoimentos e do conjunto de respostas dadas nos questionários nos permitiu mapear os sentidos atribuídos à formação profissional em serviço, dando origem a conteúdos comuns que formam um sistema de interpretação pelo qual professores e gestores representam essa questão.

No caso dos gestores escolares, os conteúdos formam dois conjuntos semânticos distintos: um que corresponde a uma visão da formação contínua como meio de melhorar os resultados do sistema e outro formado por um conjunto de ideias através das quais se percebe pouco ou nenhum sentido de responsabilidade profissional pela autoria e autonomia na promoção da formação contínua oferecida no seu âmbito de atuação.

No primeiro conjunto, que se fundamenta na perspectiva de formação contínua como um meio de melhorar os resultados do Sistema, desvelam-se tendências e encaminhamentos distintos no Sistema B e C, nas quais parte de seus gestores parecem atribuir este significado aos processos de capacitação profissional que desenvolvem.

A representação de formação como elemento de melhoria dos resultados surge, a nosso ver, como resposta às pressões originadas a partir de diversos elementos presentes no social e que interferem no cotidiano das escolas e dos sistemas municipais de ensino. Não descartamos, nesse conjunto de fatores, a possibilidade do aumento dos níveis de consciência a partir das reflexões sobre a função social da escola e da necessidade de ensinar a todos. No entanto, o que nos parece é que o elemento central desse conjunto de pressões está focado no IDEB, que, no caso dos municípios pesquisados, é gerado principalmente a partir dos resultados da Prova Brasil, aplicada aos $5^{\circ}$ anos do ensino fundamental. O índice, acompanhado pelos diversos setores da sociedade, incluindo o setor legislativo, os tribunais de contas, os pais de alunos, a imprensa, etc., passa, nos últimos anos, a ser considerado como parâmetro único de qualidade de ensino. Em 
outras palavras, "A melhoria da qualidade do ensino tende, assim, a se traduzir, em última análise, no seu equacionamento em termos da capacidade de alcançar um bom resultado na pontuação do IDEB” (BARRETO, 2012, p.745).

Os dados gerados pela Prova Brasil têm funcionado como elementos balizadores das políticas públicas de educação, dentre os quais se inserem as políticas voltadas à formação de professores. Tais direcionamentos são confirmados por estudo qualitativo realizado em quatro sistemas de ensino sobre os diferentes usos dos dados das avaliações externas. A pesquisa apontou que

\begin{abstract}
Apesar de os sistemas de ensino pesquisados destacarem a apropriação da avaliação externa pelas escolas como um dos objetivos dessa política, foi possível perceber lacunas em relação às ações de formação mais específicas a respeito das possibilidades em utilizá-las no cotidiano escolar. Embora tenham sido obtidos alguns relatos sobre a ocorrência de momentos de formação junto às equipes escolares acerca das avaliações externas, na maioria dos casos se tratavam de ações direcionadas prioritariamente aos aspectos diretamente relacionados às etapas de aplicação da avaliação, aos esclarecimentos quanto à metodologia adotada ou até mesmo aqueles dirigidos à divulgação dos seus resultados. Esses tópicos, embora importantes, não se confundem com o desafio adicional de se pensar, discutir e deliberar em relação ao que pode ser feito com os resultados e como o desenho do sistema de avaliação adotado pode ser relacionado à prática docente (FUNDAÇÃO CARLOS CHAGAS, 2012, p. 93).
\end{abstract}

Assim como o observado em nossa pesquisa, o estudo constata poucas ações de formação voltadas para a reflexão dos processos de ensino e aprendizagem presentes no cotidiano das escolas, sobre "como" cada escola, cada sistema cria mecanismos inovadores que, de fato, produzam os avanços esperados.

Concordamos com Penin (1995) sobre a necessidade de entender como os "sujeitos" reagem às representações presentes no coletivo. "Entendo ainda que é a forma que toma essa reação do sujeito (mimese ou práxis), e não suas representações, que introduz no social novos elementos, nele interferindo” (PENIN, 1995, p.10).

Conforme sinaliza Lefebvre (1983), as representações não são falsas, nem verdadeiras, mas sinalizam uma realidade, podendo orientar ações e tomar forma. No caso dos quatro sujeitos entrevistados, as representações de formação contínua como meio de melhorar os resultados do ensino parecem orientar suas ações em direções variadas, ganhando forma, se objetivando. Nossa análise das representações desses sujeitos sugere que apenas em relação à gestora escolar (diretora de escola) do Sistema 
B tal objetivação parece possível de gerar conhecimento novo. Suas mudanças de postura na condução das ações de formação contínua na unidade onde atua revelam tentativas de superação da realidade observada, através da atitude crítica presente em suas condutas e na maneira de conceber o papel do professor na construção de seus saberes pedagógicos, o que, a nosso ver, pode constituir-se no germe da mudança, no sentido que nos propõe Lefebvre (1983). Já no caso da gestora municipal do mesmo sistema, seu saber crítico bem formulado e explicitado em suas manifestações não sugere articulação diferenciada com outros aspectos da realidade vivida de modo a permitir identificar ações ou objetivações inovadoras (uma obra, conforme conceito de Lefebvre). Ou seja, mesmo entendendo a necessidade de formação contínua e mesmo atuando como uma das propositoras de diversos cursos e oficinas de formação no município - o que revela um saber teórico bem estruturado (ou concebido, conforme Lefebvre) -, ela parece considerar pouco a importância e o protagonismo do professor no seu processo de formação contínua. Parece faltar a essa gestora, apesar do seu saber, uma atitude crítica, na qual o sujeito do ensino (o professor) e sua vivência na relação com os sujeitos da aprendizagem (alunos) devem ser considerados em propostas de formação contínua.

No caso do gestor municipal do sistema $\mathrm{C}$ e da coordenadora pedagógica do mesmo sistema, suas representações parecem tomar a forma de outras representações, conduzindo as ações em um sentido oposto ao que se desejaria, uma vez que não foram observadas propostas que pudessem constituir-se em verdadeiros processos de formação contínua. Apesar de atribuírem à formação contínua um sentido de melhoria nos resultados, pouco se mostram como responsáveis pela inovação, demonstrando pouca autonomia frente às suas responsabilidades de formadores.

Tal posicionamento compõe o conteúdo do segundo conjunto semântico, no qual se enquadram os gestores dos Sistemas A e C, e a coordenadora pedagógica do Sistema B. As manifestações desses profissionais nos revelaram, independente da área de atuação de cada um deles, uma constante reprodução de práticas cujos resultados mais se assemelham a produtos que a obras, conforme o conceito de Lefebvre.

A autonomia que proclamam em seus discursos parece de fato não existir, uma vez que o conjunto de ações de formação descrito parece orientar-se por uma perspectiva já determinada anteriormente por outras instâncias administrativas. Desse modo suas representações sobre formação contínua os aproxima do modelo de 
profissional que Contreras denomina expert infalível (CONTRERAS, 1999). Segundo o autor sua autonomia é enganosa e se baseia no entendimento do ensino

(...) como aplicação técnica, como prática dirigida à obtenção de resultados ou produtos previamente definidos, não é uma prática criativa, e sim apenas reprodutiva (...). As capacidades que se associam à ação autônoma, como a deliberação e o juízo, ficam aqui reduzidas a um conjunto de regras que devem ser seguidas. Ao ser, além disso, dependentes de outras instâncias e de outros técnicos de um escalão superior, os quais esboçam seu trabalho ou os modos de racionalização que deverão assumir para si, sua capacidade de ação autônoma se encontra minimizada. (CONTRERAS, 1999, p. 101)

Ao proclamarem uma autonomia aparentemente ilusória, revelam ora atitudes conformadas e de aprovação dos modelos que se apresentam, ora apatia e insatisfação. Ocorre que, mesmo aqueles que desaprovam o modelo e se mostram desconfortáveis em relação às formas de conduzir a formação contínua, como é o caso da coordenadora pedagógica do Sistema A, não parecem seguros ou incentivados a ousar, a enfrentar possíveis imprevistos que qualquer ação que se propõe a mudança pressupõe. O conformismo de alguns ou inconformismo de outros parece justificar-se no pressuposto de que pensar formas inovadoras de formação, participando ativamente de um planejamento que se volte para cada realidade específica não é uma tarefa que lhes cabe.

Reconhecemos que lançar-se pessoal e profissionalmente a ações desse tipo pressupõe considerar a imprevisibilidade dos acontecimentos, assumindo os riscos de sucesso ou fracasso do empreendimento educativo. Conforme aponta Contreras (1999), "o transcurso do progresso educativo se parece mais com o vôo de uma borboleta do que com a trajetória de uma bala" (CONTRERAS, 1999 apud JACKSON, 1991, p. 197). Mas esclarece que

Só o ato de assumir e o compromisso pessoal com opções pedagógicas podem proporcionar o substrato para enfrentar o imprevisto, o incerto, o ambíguo, já que as respostas e sua justificação devem ser elaboradas de forma implícita, normalmente no decorrer da própria atuação (CONTRERAS, 1999, p. 105)

Ao mesmo tempo, assumir tamanhas incertezas de forma solitária e sem o apoio e incentivos necessários pode representar obstáculos intransponíveis para esses sujeitos que se encontram imersos num determinado jeito de pensar as ações educativas, 
especialmente quando estas se referem ao campo da capacitação profissional, aumentando ainda mais os desafios.

Além disso, está claro para nós que a aparente passividade e a apatia desses gestores nascem a partir de contextos variados, cujas configurações nos propõem também explicações diversas. Conforme esclarece Forquin (1993) ao ampliar a definição de cultura como matriz imutável propõe-nos

(...) reconhecer, com efeito, que esta ordem humana de cultura não existe em lugar nenhum como um tecido uniforme e imutável, mas que ele se especifica, ao contrário, numa diversidade de aparências e de formas segundo os avatares da história e as divisões da geografia, que ele varia de uma sociedade a outra e de um grupo a outro no interior de uma mesma sociedade, que ela não se impõe jamais de forma certa, incontestável e idêntica para todos os indivíduos, que ela está submetida aos acasos das "relações de força simbólicas" e a eternos conflitos de interpretação, que ela é imperfeita, lacunar, ambígua nas suas mensagens, inconstante nas suas prescrições normativas, irregular nas suas formas, vulnerável nos seus modos de transmissão e perpetuação. (FORQUIN, 1993, p. 14-15)

A definição acima proposta nos impulsiona a considerar que muito das representações de gestores e professores justifica-se a partir das respostas encontradas nas configurações locais, da observação da maneira de conduzir os processos de formação, a partir da organização das secretarias de educação no que tange à estrutura oferecida para a formação contínua, da organização legal de incentivo à participação dos professores na formação contínua.

Dessa forma, sem desconsiderar as influências em âmbito mais geral que influenciam as formas de pensar, sentir e agir em relação ao tema, está claro para nós que a cultura de condução das políticas locais de formação tem determinado as representações sobre formação contínua desses profissionais, ao mesmo tempo em que é por elas determinada e constituída ao longo de suas histórias particulares.

Nesse mesmo sentido, vimos, ao apreender as representações sobre formação contínua dos professores dos três sistemas, que estas se ligavam de forma mais qualitativa à prática pedagógica nos contextos em que a dimensão pedagógica se apresentava de maneira mais significativa nos processos, como é o caso do Sistema B. Nessa mesma perspectiva, a ausência de propostas inovadoras de formação nos demais Sistemas parece refletir representações sobre formação contínua mais voltadas aos benefícios salariais e às evoluções na carreira, sobressaindo nessas mesmas representações os aspectos quantitativos e de ordem prática. Enquanto no Sistema B, a 
ausência de incentivos na carreira em decorrência da participação em cursos não pareceu oferecer empecilhos para que os professores ligassem prática pedagógica e formação, nos outros dois essa ligação se mostrou, de certa forma, mais frágil.

Dessa maneira, nosso pressuposto é que os processos de condução das formações, especialmente o "como" as redes planejam, executam e acompanham seus programas de capacitação profissional pode estar determinando as representações de seus profissionais em relação ao tema. Fullan (2000), ao se referir à influência que os ambientes exercem no desenvolvimento profissional e no incentivo às culturas colaborativas, afirma que "as escolas costumam ter os professores que merecem" (FULLAN, 2000, p. 47).

Gatti et al. (2011) sinalizam para a necessidade de que sejam abandonadas as formas tradicionais de capacitação profissional. Nesse sentido, traz as reflexões de Imbernón (2009) em que descreve a urgência de mudanças culturais nas instituições, o que exigiria dos sistemas de ensino novas posturas na condução de seus projetos de formação contínua, compreendendo mudanças desde o planejamento até a avaliação, com ênfase na autonomia das escolas e na participação dos professores, o que, no nosso entendimento, não excluiria a função das secretarias de educação como principais motivadores de um formato mais colaborativo de formação.

Compreendemos como natural o posicionamento dos professores ao reconhecer a necessidade de que as formações sejam incluídas nos incentivos à carreira. No entanto, é preciso cautela, uma vez que há o risco de que a formação possa ser vista unicamente como incentivo salarial ou de promoção (IMBERNÓN, 1996, p. 105).

A falta de uma estrutura organizacional adequada dos processos de formação pode levar à ideia de que a simples participação nos cursos, sem a devida avaliação de sua significação para a prática docente, poderia ser suficiente para que tais programas cumprissem sua função. Enxergar a formação apenas como possibilidade de incentivo na carreira pode significar que tanto sistemas de ensino como parte dos professores possam estar desvirtuando a real função da formação contínua, mudando seu foco apenas para a obtenção de vantagens e não por considerar o processo de formação como algo que se estenda "ao terreno das capacidades, habilidades, emoções e atitudes", questionando "continuadamente os valores e as concepções de cada professor e da equipe de forma coletiva” (IMBERNÓN, 2010).

Em síntese, concluímos que as manifestações sobre as motivações dos professores dos três sistemas quanto à participação na formação contínua nos levam ao 
desvelamento de representações sobre formação contínua como um caminho de melhoria da prática pedagógica, mas também como um caminho para a obtenção de vantagens na carreira.

Não pretendemos aqui resolver as contradições que se apresentam, apenas apontá-las. Os cenários são distintos, revelando diferentes configurações de carreira e propostas de formação. Além disso, são as formas que as redes utilizam para por em prática os artifícios que têm a seu dispor para o desenvolvimento de programas de formação que parecem estar interferindo sobremaneira no modo de pensar e agir dos professores em relação ao seu processo de formação profissional. 


\section{CONSIDERAÇÕES FINAIS}

É amplamente reconhecida a importância da formação contínua para o desenvolvimento profissional dos docentes, tendo em vista as novas exigências frente às demandas educacionais e à necessidade de desenvolvimento da qualidade dos processos educativos no país.

Conforme relatamos, são várias as pesquisas que apontam para a necessidade de mudanças no campo da formação continuada desenvolvida por sistemas municipais e estaduais. Muitas delas indicam uma distância considerável entre os objetivos propostos e os resultados esperados, uma vez que tais propostas não têm gerado as mudanças esperadas na prática docente e, em consequência, pouco interferido na elevação dos níveis de qualidade da educação oferecida. Além disso, as escolas se prestam de forma ineficiente à organização de um trabalho de formação mais colaborativo, visto que a estruturação do trabalho pedagógico escolar é, na maioria das vezes, marcada pelo individualismo e ausência de colegialidade. O que se nota, desta forma, é a geração de poucas mudanças na prática pedagógica dos professores e, conforme já apontado, as mudanças constatadas pelas pesquisas se dão mais no nível do discurso elaborado sobre elas do que nas condições concretas em que se apoiam.

No caso dos sistemas municipais de ensino, os desafios enfrentados são ainda maiores, já que, em decorrência da recente descentralização das decisões sobre o ensino, ainda se encontram em fase de estruturação de suas políticas de educação, dentre as quais, as políticas de valorização do magistério e os programas de formação contínua.

Ao nos utilizarmos da teoria das representações de Lefebvre, elaboramos um conjunto de instrumentos de pesquisa a fim de alcançar quais representações sobre formação de professores possuíam tanto os professores de ensino fundamental como os gestores escolares e municipais dos três sistemas de ensino pesquisados.

Nesse sentido, foi a referida teoria que nos trouxe uma lente através da qual pudemos enxergar a realidade a partir da perspectiva antropológica dialética de Henri Lefebvre, considerando de forma contextualizada os discursos dos sujeitos envolvidos, suas motivações e representações, tendo como "pano de fundo" as culturas específicas, seus contextos institucionais e educacionais, atentando especialmente, na análise desse contexto, a estrutura organizacional das secretarias de educação voltada ao 
cumprimento das ações de formação contínua no município, enfatizando o "como" e mediante quais circunstâncias se dá o trabalho de qualificação profissional.

A partir da análise das diferentes configurações encontradas, considerando a qualidade das propostas de formação, a estruturação dos planos de carreira no que se refere à evolução funcional via acadêmica e não acadêmica, as representações dos sujeitos envolvidos na pesquisa, pudemos avançar na compreensão da interferência que esses diferentes elementos exercem uns sobre os outros, moldando a realidade.

Está clara para nós a mútua influência exercida pelas representações entre os diversos sujeitos, sejam eles professores ou gestores. Ao mesmo tempo, entendemos que são os gestores - coordenadores pedagógicos, diretores de escola, equipes técnicas da secretaria de educação - os profissionais cuja função proporcionaria as melhores condições na proposição de mudanças efetivas nessa área.

Assim, parece-nos que as representações (objetivadas ou não), apreendidas a partir da manifestação dos gestores, exercem importante influência na qualidade das ações de formação desenvolvidas em cada rede, verificando-se, dentre os nove gestores entrevistados, apenas dois cujas ações sugeriram indícios de superação de suas representações sobre formação contínua. Quanto aos demais, é bastante marcada a representação de formação contínua como responsabilidade de outrem, uma vez que o conjunto de suas ações e palavras conduziram a práticas gestoras de formação cujos processos decisórios, inerentes ao conjunto das ações de formação contínua, se encontravam transferidos, na maioria das vezes, para outros sujeitos, entidades, órgãos ou instâncias administrativas.

É interessante notar que, ao desvelarem-se as representações docentes sobre o tema, os professores do Sistema B, cujos gestores parecem possuir posturas mais comprometidas com a qualidade da formação contínua oferecida, os mesmos sinalizam para representações sobre a formação profissional em serviço como um meio de melhorar a prática pedagógica e aperfeiçoar sua prática em sala de aula.

Por outro lado, nas representações de gestores, do Sistema A e C, onde pouco se nota a presença da gestão, seja ela em nível municipal ou escolar, propondo inovações, considerando o próprio contexto e agindo sobre ele de forma autônoma, também os professores tendem a valorizar menos os processos de formação contínua como fonte de conhecimento e melhoria da prática pedagógica, considerando de forma bastante acentuada as possibilidades de melhoria de salário via evolução funcional. 
Vimos, então, que nas redes onde se observa maior grau de autonomia e pertencimento por parte dos gestores, encontramos propostas de formação mais inovadoras, em maior quantidade e, presumivelmente, de melhor qualidade que nos locais onde foram notadas atitudes mais passivas por parte dos responsáveis pela condução de propostas na área da formação profissional.

Mesmo reconhecendo na cultura das instituições e nos estilos de liderança valorizados em cada Sistema fatores que estimulam ou emperram a proposição de um trabalho qualitativo de formação, parece-nos que a essas equipes de gestão, cuja autonomia nos processos de formação contínua pouco se nota, falta o encorajamento ou suporte técnico necessário para o empreendimento de ações que ultrapassem os limites do discurso e que considerem desde o diagnóstico das necessidades de cada rede até os processos de avaliação conjunta dos avanços obtidos por cada Sistema.

Ao tentar desvelar as representações sobre formação contínua que possuíam os profissionais de ensino dessas redes, nossa atenção se voltou para as possibilidades de superação dessas representações e, em que medida, poderiam estar se constituindo em obras, no sentido proposto por Lefebvre. Como já explanamos ao longo do texto, os indícios dessas realizações se revelam mais fortemente no caso de uma das gestoras do Sistema B, representando, dentre os entrevistados, a única a demonstrar segurança e sentimento de pertencimento, atribuindo a sua função de gestora um papel determinante na organização da formação docente desenvolvida em sua unidade. A atitude crítica observada em suas palavras e ações parece nos remeter a imagem do "homem das fronteiras", aquele que mesmo imerso nos desafios postos pela realidade à qual pertence, busca meios de ultrapassá-la, superá-la, propor o diferente. Está, como sugere Lefebvre (1983), dentro e fora, incluído e excluído, suportando esta tensão. É no "homem das fronteiras" que o autor reconhece os indivíduos nas melhores condições para a realização de obras. Por outro lado, os demais gestores entrevistados parecem representar outra categoria de indivíduos descrita pelo autor como aqueles que se posicionam à margem, comportando-se como vítimas, e ali permanecendo confortavelmente.

A presença de sujeitos dotados de autonomia é, a nosso ver, escassa, devido a diversos aspectos relacionados à estruturação do trabalho voltado à formação docente em serviço, atribuída, na maioria das vezes, unicamente ao coordenador pedagógico. Como já explanamos no início desse trabalho, são diversos os problemas que emperram o desenvolvimento de uma formação contínua mais eficaz e que voltada às reais 
necessidades dos docentes no interior das escolas. Aliás, nem sempre é esse o ponto de partida, uma vez que, por diversas razões, os responsáveis pela formação contínua são obrigados a seguir orientações que lhes são externamente impostas.

Atualmente, constatamos inúmeras iniciativas de formação propostas por agências externas, ONGs, Ministério da Educação, universidades, consultorias terceirizadas, etc., cujos conteúdos dos cursos são, na maioria das vezes, de excelente qualidade. O que parece ocorrer é que essas modalidades de formação profissional, como o próprio PNAIC e o Ler e Escrever, dentre outros, ainda que definam, de forma genérica, as ações previstas para a coordenação pedagógica, pouco promovem uma reflexão que extrapole os passos programados pelos cursos e que incidam na construção da autonomia desses gestores e retirando-os da condição de reprodutores de práticas.

O que nos parece é que a superação da representação sobre formação contínua como responsabilidade de outrem passa necessariamente pelo equacionamento do conflito presente na articulação das forças internas e externas à unidade escolar, através de um viés de atuação que reconcilie as forças de baixo para cima e as de cima para baixo, proporcionando às equipes o urgente e necessário apoio técnico e o encorajamento fundamental para que se construam líderes mais seguros, autônomos e competentes para a condução de propostas de formação verdadeiramente inovadoras, voltadas aos contextos e necessidades locais, agregados qualitativamente à vida profissional dos educadores.

Entendemos que nosso estudo contribuiu não só para desvelar a mútua influência exercida pelas representações de professores e gestores, mas principalmente por enfatizar a força de cada contexto específico no que tange a capacitação docente - suas propostas de formação, legislação, jornada de trabalho, etc. - nas representações sobre formação contínua verificadas em cada um dos Sistemas.

Por isso, entendemos como imprescindível o desenvolvimento de investigações sobre as possíveis estratégias bem sucedidas na gestão dos programas de formação contínua desenvolvidos por estados e municípios, incluindo a forma de apropriação de cursos organizados por outras instâncias e os sentidos a eles atribuídos no cotidiano escolar. Desvelar essas possíveis obras e compreender como podem estar se constituindo poderia oferecer mais pistas e ampliar o entendimento e a apreensão das representações sobre formação contínua, com vistas a sua superação. 


\section{REFERÊNCIAS}

AFONSO, A. J. Estado, mercado, comunidade e avaliação: Esboço para uma rearticulação crítica. Educação \& Sociedade, ano XX, n69, Dezembro/99.

ALMEIDA, G. B. Representações docentes no Ensino Médio: Leitura, escrita e aprendizagem por competências no currículo do Estado de São Paulo.2012. Tese (Doutorado em Educação) - Universidade de São Paulo

ALTOBELLI, C.C. A. As dificuldades e queixas de professores alfabetizadores em tempo de formação continuada. 2008. Dissertação (Mestrado) - Pontifícia Universidade Católica de São Paulo.

ANDRÉ, M. E. D. A. A produção acadêmica sobre formação docente: um estudo comparativo das dissertações e teses dos nos 1990 a 2000. Revista Brasileira de Pesquisa sobre Formação de Professores. Autêntica, v. 1, n.1, p. 41-56, ago./dez. 2009 .

ASSIS, T. P. de. Formação Continuada em serviço: o olhar do professor/ Tatiana Pinheiro de Assis. Presidente Prudente: (s.n.)2014. 198p.

BALDOCK, J.; MANNING, N.; VICKRSTAFF, S. Social policy. 2. ed. Oxford: Oxford University, 2003.

BARDIN, L. (2006). Análise de conteúdo (L. de A. Rego \& A. Pinheiro, Trads.). Lisboa: Edições 70. (Obra original publicada em 1977)

BARRETO. E. S. de S. Políticas de Currículo e Avaliação e Políticas Docentes. Cadernos de Pesquisa. no 42. p.738-753. Dez. 2012.

BAUER, A. Avaliação de impacto de formação docente em serviço: o Programa Letra e Vida. 2011. Tese (Doutorado em Educação) - Universidade de São Paulo 
BRASIL. (Constituição de 1988). Constituição da República Federativa do Brasil. Brasília: Senado Federal, 1988. Disponível em: < http://www.planalto.gov.br/ccivil_03/Constituicao/Constituicao.htm.

BRASIL. Lei No 9.394, de 20 de dezembro de 1996. Lex: Leis de Diretrizes e Bases da educação Brasileira (LDB), Brasília, 1996.

BRASIL, Orientações Gerais para a rede de formação continuada. Brasília, 2005.

BORDIGNON, G.; GRACINDO, R. V. Gestão da educação: o município e a escola. In: FERREIRA, N. S. C.; AGUIAR, M. A. S. (Orgs.). Gestão da educação: impasses, perspectivas e compromissos. 4. ed. São Paulo: Cortez, 2004. p. 147-176.

CARR, W., Kemmis, S. Becoming Critical: Education, Knowedge and Action Research London: The Falmer Press, 1986

CONTRERAS, J. A autonomia de professores. São Paulo: Cortez, 1999. 296 p. 15,5 x $22,5 \mathrm{~cm}$.

DAVIS, C.L.F.; NUNES, M., M. R.; ALMEIDA, P.C.A. de. Formação continuada de professores: uma análise das modalidades e das práticas em estados e municípios brasileiros; relatório final. São Paulo: Fundação Victor Civita, Fundação Carlos Chagas, jun. 2011.

DINIZ PEREIRA, J. E. A pesquisa na formação e no trabalho docente/ organizado por Júlio Emilio Diniz Pereira e Kenneth M. Zeicnher.- Belo Horizonte: Autêntica, 2002. 200p. (Trajetória, 9)

FRANCO, M. L. P. B. Análise de Conteúdo. 3. ed. Brasília: Líber Livro, 2008.

FREITAS, M. T. de A. A abordagem sócio-histórica como orientadora da pesquisa qualitativa. Cadernos de Pesquisa. Print version. no.116. São Paulo, jul. 2002.

FULLAN, M. Change forces with a vengeance. London: Falmer, 1993 
FUNDAÇÃO CARLOS CHAGAS. Relatório Final: Uso da Avaliação Externa por Equipes Gestoras e Profissionais Docentes: Um estudo em Quatro Redes de Ensino Público. São Paulo. Fundação Carlos Chagas, 2012.

FUNDAÇÃO SISTEMA ESTADUAL DE ANÁlISE DE DADOS - SEADE. Disponível em: (acesso em 05/2014).

FORQUIN, J. C.; Escola e Cultura: as bases sociais e epistemológicas do conhecimento escolar. Porto Alegre: Artmed, 1993.

FUSARI, J. C.; FRANCO, A. de P. A formação continuada como um dos elementos organizadores do projeto político-pedagógico da escola. Salto para o futuro. Boletim 2005, 01 a 05 ago. 2005. Disponível em: $<$ http//www.tvebrasil.com.br/salto/boletins2005/fcptext2.htm>. Acesso em 10 dez/2013.

GATTI, B. A. Políticas Docentes no Brasil: Um Estado da Arte / Bernardete Angelina Gatti, Elba Siqueira de Sá Barreto e Marli Dalmazo de Afonso André. Brasília: UNESCO, 2011. 300p.

GATTI, B. A. Os Professores e Suas Identidades: o desenvolvimento da heteregeneidade. Cadernos de Pesquisa, n98, Fundação Carlos Chagas, São Paulo: Cortez, 1996.

GUNTHER, H. Como elaborar um questionário ( Série: Planejamento de Pesquisa nas Ciências Sociais, nº2). Brasília, DF : UnB, Laboratório de Psicologia Ambiental. 2003.

HARGREAVES, A., FULLAN, M. A Escola como organização aprendente: buscando uma educação de qualidade. Porto Alegre: Artmed, 2000.

IMBERNÓN, F. Em busca del Discurso Educativo. Buenos Aires: Edti. Magistério del Rio de la Plata, 1996.

IMBERNÓN, F. Formação Continuada de professores. Porto Alegre. Artmed, 2010.

IMBERNÓN, F. Formação docente e profissional: formar-se para a mudança e a incerteza. São Paulo: Cortez, 2002 (3. ed), 2010 (8. ed.). 
KONDER, L. O que é dialética. São Paulo: Brasiliense, 1997. Coleção Primeiros Passos, $\mathrm{n}^{\mathbf{0}} 23$.

LEFEBVRE, H. La presencia y la ausencia - contribuición a la teoria de las represenaciones. México: Fondo de Cultura Económica, 1983. edição original: 1980.

LUTFI, E.P.; SOCHACZEWSKI, S.; JAHNEL, T.C. As representações e o possível. In: MARTINS, J.S. (Org.). Henri Lefebvre e o retorno à dialética. São Paulo: Hucitec. 1996. p. 87-97.

LELLIS, L. de O. Um estudo das mudanças relatadas por professores de ciências a partir da formação continuada. 2003. Dissertação ( Mestrado em Educação) Universidade de São Paulo.

MANZINI, E. J. A entrevista na pesquisa social. Didática, São Paulo, v. 26/27, p. 149 $-158,1990 / 1991$.

MARTINS, A. M. Uma análise da municipalização do ensino do Estado de São Paulo. Cadernos de Pesquisa n⿳ 120. São Paulo. Nov. 2003.

MENDES, C. C. T. HTPC: Hora de Trabalho Perdido Coletivamente?/ Cíntia Cristina Teixeira Mendes. Presidente Prudente: (s.n.). 2008. 113p.

MOSCOVICI, S. A psicanálise, sua imagem e seu público/ Serge Moscovici; Petrópolis: Vozes, 2012.

MOSCOVICI, S. Representações Sociais: Investigações em psicologia social. $7^{\mathrm{a}}$ ed. Petrópolis, RJ: Vozes, 2010.

NÓVOA, A. O regresso dos professores. Pinhais: Melo, 2011

NUNES, N. N. Conhecimento escolar: um estudo de representações sociais e professores/ Nadir Neves Nunes. Campinas, SP (s.n.), 2010. 
PAZ, F. M. da. Estatutos, planos de carreira e valorização do magistério público: um estudo dos municípios sedes das regiões administrativas do Estado de São Paulo. Tese de doutorado. Presidente Prudente: 2014

PAZ, F. M. da. O índice de desenvolvimento da educação básica (IDEB): um estudo do município de Santa Fé do Sul (SP). Marília, 2011. 189p.

PENIN, S. T. de S. ROBERTI, S. Representações Sociais e Representações do Sujeito: Dialogando com Moscovici e Lefebvre. In Representações Sociais: Fronteiras, interfaces e conceitos. Curitiba: Champagnat : São Paulo : Fundação Carlos Chagas, 2013.

PENIN, S. A professora e a construção do conhecimento sobre o ensino. Cad. Pesq., São Paulo, n.92, p. 5-15, fev. 1995.

PENIN, S. Cotidiano e Escola: a obra em construção/ Sonia Penin. - 2 ${ }^{\text {a }}$ Ed.- São Paulo: Cortez, 2011.

QEDU.org. www.qedu.org.br. Acesso em 03/2015.

RAMOS, M. D. Formação Continuada de Professores: Novos arranjos institucionais após a descentralização do Ensino Fundamental/ Marilú Dascanio Ramos- Campinas, SP (s.n.) 2013.

SAVIANI, D. O Plano de Desenvolvimento da Educação. Análise do projeto do MEC. Educação e Sociedade, Campinas Vol. 28 nº100, p.1231-1255, out. 2007.

SACRISTÁN, J. G. Compreender e transformar o ensino / J.Gimeno Sacristán e A. I. Pérez Gomes, trad. Ernani F. da Fonseca Rosa - 4ª - ArtMed, 1998.

SOUZA, S. M. Z. L. Avaliação em larga escala da educação básica no Brasil: possíveis impactos no currículo. In: Carlinda Leite; José Augusto Pacheco; Antônio Flávio Barbosa Moreira; Ana Mouraz (Org.). Políticas, Fundamentos e Práticas do Currículo. Porto: Editora Porto, 2011, v., p. 238-251 
SCHON, D. Educando o Profissional Reflexivo: um novo design para o ensino e a aprendizagem/ Donald A. Schon; trad. Roberto Cataldo Costa - Porto Alegre: Artes Médicas Sul, 2000.

SCHON, D. The reflective practitioner. New York: Basic Books, 1983.

TARDIF, M.; LESSARD, C. O trabalho docente: elementos para uma teoria a docência como profissão de interações humanas. 6. ed. Rio de Janeiro: Vozes, 2011.

VELIENGO, A. Programa de Formação de Alfabetizadores em Portugal e no Brasil: representações de professores/Amanda Valiengo. Marília, 2012. $251 \mathrm{f}$.

ZEICHNER, K. M. Uma análise crítica sobre "Reflexão" como conceito estruturante na formação docente. Educação e Sociedade. Campinas. Vol. 29, nº103, p. 535-554, maio/ago. 2008. 


\section{Anexo 1 \\ Roteiro de entrevista semi-estruturada}

\section{Questões}

1. Existência e tipo de formação oferecida pelo município

2. Como se dá o processo de planejamento das formações oferecidas

- Definição dos temas

- Áreas de conhecimento abordadas

- Participação dos professores

- Público-Alvo das formações

- Existência de diretrizes e cronogramas de formação

3. Como se dá a articulação da formação oferecida pelo sistema e o trabalho de formação desenvolvido nas escolas.

- Formas de acompanhamento por parte da secretaria de educação

- Formas de registro

- Articulação com a prática de sala de aula

4. Como se dá o processo de avaliação da formação desenvolvida na rede de ensino

- Forma de acompanhamento dos resultados 


\section{Anexo 2}

\section{Transcrições da gravação em áudio de entrevistas com os gestores escolares e municipais $^{36}$}

\section{SISTEMA A}

\section{Gestora Municipal do Sistema A - GMSA}

\section{Entrevistadora: Fale sobre a formação contínua oferecida aos professores da rede oferecida pela secretaria da Educação}

GMSA: Desde que eu entrei, que foi em 2009, a gente sempre tem uma reunião, da Secretaria, buscando verificar as fragilidades que estão acontecendo com o município. Em 2010 nós começamos o nosso processo diagnóstico. Esse processo diagnóstico visava assim, fazer realmente uma avaliação, não era só uma verificação de onde que as crianças estavam, mas assim, fazendo essa avaliação, e tendo tomado essas decisões. Assim: o que as crianças não estavam atingindo, sendo assim, observar o que os professores que estavam com dificuldade de ensinar e, nesse sentido, fazer uma proposta de formação pra que nós pudéssemos subsidiar esses professores. Então desde que eu estou como orientadora, a proposta da secretaria é sempre nesse norte. De nós estarmos olhando, percebendo através de reuniões, das visitas nas escolas, analisando semanário, e nesse processo diagnóstico, que nós precisávamos oferecer aos professores pra estar dando um suporte no ensino, porque nós sabemos que tanto a criança tem o direito de aprender quanto o professor o direito de saber ensinar, não é? Então, é mais ou menos nessa visão e dessa forma que a gente vem pensando na formação. Então nós realizamos diversas formações próprias da secretaria, que em 2010 foi realizado para o ensino fundamental de 9 anos. Uma reflexão e também parcerias. A gente tem parceria com o estado, que é o programa Ler e Escrever e a parceria com o governo federal, que foi desde o Pró-letramento e o PNAIC, que é o programa que atualmente está aí, tentando fazer com que a alfabetização consiga melhores resultados. Então é mais ou menos nessa linha que a gente procura. Fora isso, a secretaria também pensando no aluno do ensino fundamental, nós oferecemos o programa "Amigos do Zip" que fazia também formação com os professores com a questão do lúdico e dentro de história, dentro do lúdico e estar desenvolvendo com a criança o saber olhar para a dificuldade. Então, como posicionar diante de uma dificuldade. Então, esse programa vem a fortalecer no aluno esse saber enfrentar as dificuldades.

Entrevistadora: Ele não é voltado pra nenhuma área do currículo?

GMSA: Se nós pensarmos, ele é transversal. E ele contribuiu por que eu que fui praticamente o elo da secretaria com esse programa que a secretaria ofereceu. Nós vimos nos relatos dos professores e das próprias crianças a questão desse alicerce emocional que estava contribuindo com a aprendizagem. Então a gente viu assim um elo, não querendo dizer que foi o fator determinante, mas que essa formação, com esses professores, assim, nos relatos que nós temos, inclusive, eles colocam que eles aprenderam sabe olhar o aluno, não é? Que foi assim, como se ampliasse assim esse

\footnotetext{
${ }^{36}$ A titulo de preservação da identidade dos municípios, omitimos os nomes dos gestores entrevistados e de pessoas citadas por eles durante as entrevistas.
} 
olhar do aluno. Então contribuiu pra isso e o próprio aluno de se fortalecer. Porque às vezes, com alguns problemas que eles vinham pra escola, eles conseguiram saber, e..., não seria dominar, mas, assim... como fazer pra não permitir que esses problemas atingissem a aprendizagem.

Entrevistadora: Certo. Isso pra todos os professores do primeiro ao quinto?

GMSA: Não. O programa amigos do Zip, ele é um programa até o terceiro ano.

Entrevistadora: E ele é uma parceria com alguma entidade?

GMSA: Não esse é um programa que tem franquia.

Entrevistadora: Ah, contratado.

GMSA: É contratado pela secretaria de educação. Foi numa formação que nós fizemos fora. Nós vimos, ficamos sabendo dessa formação, entramos em contato. Na época a secretária era a (*) e aí, ela passou, a gente analisou. Nós convidamos pra que viessem aqui passar pra gente toda essa formação e propomos pra rede. Era até um convite, não é nada obrigatório. E aí a participação, a adesão dessas escolas, a gente teve em 2011, nós tivemos em 2012 também e a gente percebeu o quanto foi significativo. Então, assim, o que to tentando até colocar é que a gente tem buscado esse olhar. Agora nada é $100 \%$. A gente a cada ano vai percebendo as adequações necessárias, que eu acho interessante, dessa gestão, é nesse sentido, de estar procurando verificar, tomar decisão em cima do que foi verificado e pensando nesse aluno como um todo. Sabemos o quanto a gente ainda tem que caminhar pra que cada vez mais seja possível, cada vez mais a qualidade seja fortalecida, um alto nível de aprendizagem, mas as formações tem caminhado neste sentido.

Entrevistadora: Você falou sobre um processo diagnóstico que gera os temas da formação de vocês. Como ele acontece?

GMSA: É um dos instrumentos de avaliação que nós fazemos pra nós pensarmos em avaliação. O processo diagnóstico, ele envolve a alfabetização e o letramento. Então foi nítido quando iniciou o processo diagnóstico o quanto as crianças estão mais voltadas à alfabetização propriamente dita, do que ao letramento. Então o que nós fizemos: mediante disso, nós começamos a fazer formação para que os professores pudessem estar direcionando o teu trabalho também voltado ao letramento, pra ter um equilíbrio. Porque como a gente coloca, é indissociável. Não se privilegia nem muito mais um, nem outro, mas estariam juntos. E nas primeiras, percebemos assim: como era nítido a questão do sistema de escrita, ali, os acertos, mas pautado na alfabetização e quando se via a possibilidade de estar refletindo sobre essa escrita, de estar interpretando, compreendendo, fazendo aquela leitura, construção de sentido, você percebia que caía um pouco. Então, você via essa questão que era totalmente voltada à escrita e pouca leitura, ou vice-versa. Então, esses olhares que a gente obtinha nesses resultados, a gente conversando todo o processo final de diagnóstico, a gente faz um relatório do que a gente percebeu na escola. Nós chamamos os diretores pra conversar e nós dialogamos no sentido de: olha foi esse o resultado o que você percebeu sobre isso? E dentro disso: o que você percebeu sobre isso? Era possível pontuar quais situações privilegiaram aquele resultado ou quais eram ações que as escolas tiveram, que de repente precisava mais de suporte. Então achei uma situação bem assim, produtiva, porque permitia esse diálogo de a gente estar analisando o resultado. E depois, ta. E pro ano que vem? O que vocês acham importante, o que nós podemos pensar pro ano que vem? Então a gente ia assim, pensando juntos o que seria, o que precisaria estar sendo fortalecido. Então em 
cima do que a gente percebia desse diálogo, cada diretor e coordenador de escola, que realizou também com seus professores é que a gente ia pensando nas formações.

Entrevistadora: São formações quinzenais, que você disse haver, é isso?

GMSA: Formações quinzenais?

Entrevistadora: Ah, desculpe, estou confundindo, são reuniões? Talvez quem tenha dito foi a diretora entrevistada.

GMSA: Ah, então, O "Ler e Escrever". Porque nós fazemos formações com os professores e também nós fazemos formações com os coordenadores. Está entendendo? Então o "Ler e Escrever", desde quando iniciou, iniciou para os coordenadores. Então nós fazemos quinzenalmente com os coordenadores toda uma análise desse processo de leitura e escrita e também envolvendo matemática, agora de um tempo pra cá. Com os professores, no pró-letramento eram todas as semanas que nós realizávamos com os professores, de 4 horas, entendeu? Agora essa formação que nós estamos realizando, já não. É uma vez por mês, é o dia todo, que é no sábado.

Entrevistadora: É o PNAIC?

GMSA: Isso. Então a gente está realizando esse ano essas duas formações. É uma com os professores e a outra com os coordenadores. Mas assim, o mesmo direcionamento que a gente procura dar para os professores, também os coordenadores recebem.

Entrevistadora: Certo. E aí, como é que chega esse trabalho na escola, como é que a escola realiza esse processo de formação de professores lá?

GMSA: Nós orientamos, assim, na utilização das HTPCs. Então toda a formação que a gente passa nessa formação dos coordenadores tem o intuito de, nas HTPCs, eles estarem compartilhando. E nós temos o HTPP também, que é outro momento que a gente propõe como estudo sobre essa questão de formação continuada. Nós temos também as reuniões coletivas que a gente realiza com todas as escolas, geralmente acontecem duas por ano, mais ou menos isso. Acho que no ano passado aconteceram duas também. A gente junta tudo pra falar, a gente junta tudo: professores, coordenadores, diretores e a gente faz também um momento de reflexão do ensino.

Entrevistadora: E essa mesma dinâmica também acontece com a educação infantil e as creches?

GMSA: Então, a educação infantil também tem a formação porque a educação infantil tem uma proposta pedagógica que algumas escolas, também foi convite - nada foi assim uma questão de obrigar as escolas a estarem realizando - um convite a "Fazer em cantos", não sei se você já ouviu falar desse projeto, um de Ribeirão Preto, da Carochinha, que é muito interessante porque propõe nas salas de aulas os cantos, onde as crianças vão realizar atividades em que o professor ta mediando essa aprendizagem sobre esse prisma. Então essas escolas têm formação com as orientadoras pedagógicas. Elas se reúnem com os coordenadores, agora, eu não sei te dizer precisamente em que tempo que... se é uma vez por mês, uma vez por semana, isso já não sei porque eu não estou na educação infantil e não posso te precisar a questão das datas, mas constantemente elas estão fazendo essa formação. É como a gente tem proposto que é um momento de estudo teórico e um momento de troca de experiência, porque pra nós, assim fica muito evidente que é enriquecedor esse momento de troca. Por que às vezes a teoria ta tão bonita ali no papel, mas quando a gente vai pra prática a gente sente 
dificuldade, e nesse momento de troca eles vão compartilhar como que eles fizeram determinada teoria estudada, ou determinado conhecimento obtido. Então pelo diálogo com as meninas da orientação pedagógica, a gente percebe esse momento nas formações do "Fazer em cantos". E fora isso também tem a formação dos berçários. Também tem uma orientadora pedagógica que é psicopedagoga também, que é especialista também nessa questão do berçário. Ela faz as formações com os professores que estão no berçário, porque nós temos professores no berçário. Então é mais ou menos nesse caminho.

Entrevistadora: Toda a formação que é realizada pela secretaria de educação, ela chega até a escola com uma diretriz do que fazer, do que estudar, com diretrizes mais claras, com orientações mais diretas? Qual é o espaço que a escola programar essa formação com os professores, isso no âmbito geral da secretaria?

GMSA: Então... nós nos baseamos... porque a nossa proposta enquanto secretaria de educação é alfabetização e letramento. Então a gente tem bem nítido tentar esse caminho de processo de ensino. E aí, essas orientações, a gente tem buscado nas diretrizes das expectativas que nós encaminhamos pras escolas. Nós temos as expectativas, constantemente elas estão sendo analisadas. Verificando adequações a gente realiza e nós fizemos, quando nós fizemos uma adequação agora há pouco tempo, que nós fizemos as expectativas apoiando uma ideia em Língua Portuguesa. Então nós desenvolvemos um olhar nos eixos. Então o que nós vamos ensinar quando nós falamos em compreensão e valorização da cultura escrita? O que nós vamos ensinar quando nós falamos sobre leitura? O que é o ensino da leitura? Vai além da decodificação. Então tem assim as expectativas voltadas pras leituras. O que nós desenvolvemos quando nós falamos em oralidade, o que vem a ser oralidade, o que precisa ser ensinado na oralidade. Então são expectativas que nós fizemos e discutimos com as coordenadoras. Por que a importância dos eixos? Produção de escrita? O que nós temos que nos atentar quando... Qual é o foco do ensino quando pensa em produção textual? O que não pode faltar? Então tem expectativas levantadas, como diretrizes da secretaria, buscando alcançar as diretrizes do Estado de São Paulo e também os PCNs. Então a gente tenta fazer um elo e assim dar como sugestão pra o que elas vão conseguir

Entrevistadora: E essas diretrizes, elas geram um currículo único pra rede ou o seu plano de ensino, o seu planejamento é individual?

GMSA: Penso assim, são diretrizes. Eles vão olhar, e eles vão ficar à vontade, no sentido de observar, de colocar dentro da realidade. Então cada escola vai colocar dentro da sua realidade, mas aquelas expectativas devem fazer parte. Não tem nada assim, fechado. Por que a gente pensa que cada espaço, ele vem de uma especificidade, de uma particularidade. Então algumas situações vão ser colocadas ali, que diferencia uma da outra. Seria mais ou menos isso.

Entrevistadora: O trabalho com o coordenador, com o diretor no HTPC é um trabalho de estudo, é isso? Como é o HTPC nas escolas?

GMSA: Essa é a nossa proposta. Essa é a nossa proposta em relação aos HTPCs. Olha, geralmente orientamos naquilo que eu te disse, que ela tem que estar pautada, ela tem que ter esse olhar de pensar numa situação de estudo e numa situação de troca de experiências. Então, na própria escola a gente pede muito pra estar, por exemplo, os professores dos primeiros anos conversando, os dos segundos, os do terceiros, quartos e quintos e o momento do geral, de socialização de todas, mas sempre procurando esses espaços. 
Entrevistadora: Então essa é mais uma orientação, mais geral?

GMSA: Documentos também. Sempre falando na importância desse procedimento, se baseando nisso. Não tem, suponhamos, uma resolução dizendo: é isso que você tem que fazer, não pode fugir disso daí, pode ter algumas medidas administrativas...

Entrevistadora: E como as escolas recebem? Isso acontece nas escolas?

GMSA: Eu penso que tem muitas escolas que conseguem assim ter um trabalho tranqüilo neste direcionamento. Tem algumas que precisam mais, assim, um apoio maior, tanto pro coordenador, como pro diretor. Então a gente percebe assim, que eu falando do tempo que eu tenho de prefeitura nós caminhamos muito em relação a isso, mas existem resistências ainda. Por essas resistências a gente percebe que o trabalho não caminha tão voltado a isso, mas se você pensar no que era antes você também percebe que a rede teve um avanço. Então a gente sente isso, que avançou muito.

Entrevistadora: O que objetivamente você colocaria como avanço?

GMSA: Olha, suponhamos: Se a gente pensar, vamos voltar nessa situação mais comentada que é o processo de alfabetização e letramento que a gente vê que todas as outras áreas do conhecimento perpassam por um processo de leitura e escrita. Tanto matemática, ciências, qualquer uma tem o seu processo de leitura e escrita. Então essa é uma base que a gente está lutando pra conseguir uma eficácia, por assim dizer nesse ensino, nesse processo de ensino. Então se a gente pensar, antigamente o professor era muito voltado pra aquele ensino que a gente via, vamos dizer, o tradicional.

Entrevistadora: O avanço a que você se refere seria no tipo de trabalho desenvolvido em relação ao ano passado?

GMSA: Aos outros anos, você vai percebendo esse avanço. Embora precisa ter mais, embora precisa algumas adequações, mas você percebe que teve uma mudança, e isso é legal. Penso que isso é legal.

Entrevistadora: As atividades de formação na escola, ou mesmo aqui, elas são pautadas por registros, por reflexões escritas?

GMSA: Sim, por exemplo, vamos pensar: desde o pró-letramento ou nas outras formações que a gente realizou que são próprias da secretaria, nós sempre pedimos, por exemplo, a cada encontro que a gente tem, é fazer um registro reflexivo sobre aquele encontro. Então, o professor ele vai estar fazendo esse registro e quando nós começamos a outra reunião, passou essa, no próximo encontro, no começo é a leitura do registro reflexivo, porque esse registro reflexivo ele também vai nortear se a gente precisar retomar alguma coisa. O que de repente não ficou compreendido. Então a gente busca isso, fazer reflexões sim. E a pauta, em si? Ela vem no sentido de, você dá um embasamento, por assim dizer, e faz uma reflexão de uma atividade em cima de um embasamento dado. Então, suponhamos: A gente está trabalhando gêneros textuais, nós estamos trabalhando sequiência didática. Então, o que é seqüência didática, a gente pega alguns pesquisadores da área falando sobre seqüência didática. Aí nós lançamos algumas atividades de alguns professores. Vamos analisar, houve sequiência didática?

Entrevistadora: Com os professores também?

GMSA: Com os professores também. Teve? Não teve? Por que é que não teve, ou por que é que teve? Então eles vão fundamentando, então aí a gente fecha. 
Entrevistadora: E os professores também participam com vocês dessas formações?

GMSA: Então, tem a formação para os professores e tem para os coordenadores.

Entrevistadora: Que é o Ler e Escrever?

GMSA: Isso, o Ler e Escrever nós estamos com os coordenadores e o PNAIC com os professores. O Pró-letramento com os professores, o Letra e Vida com os professores.

Entrevistadora: Para os professores dos quartos e quintos anos vocês tiveram alguma formação, porque o PNAIC é primeiro, segundo e terceiro?

GMSA: Inclusive eu estava comentando. Lembra que eu falei que a gente vai verificando? A nossa equipe conversou sobre isso na semana da passada que os professores do quartos e quintos anos nós precisamos agora estar envolvendo. Por quê? Porque nós percebemos uma fragilidade maior. Tava do primeiro ao terceiro e a gente tentou socorrer. Nós percebemos que agora o primeiro e o terceiro estar já numa estrutura, nós vamos percebendo uma tranqüilidade, não sei se assim posso dizer. Uma situação que já estar tendo um alicerce, já está tendo um resultado, sim. Nós já estamos percebendo isso. Em contrapartida nós percebemos que os quartos e quintos anos estão precisando agora do nosso apoio. Então nós estávamos conversando sobre isso de já montarmos formações concomitantes com o primeiro ao terceiro que a gente ainda precisa estar subsidiando e ao mesmo tempo estar fazendo com os quartos e os quintos. Porque a gente começa a perceber um pouco de ruptura. O aluno está vindo nesse direcionamento de alfabetização e letramento, chega no quarto e quinto ano, talvez ele sente um pouco mais voltado pra gramática e não pro letramento propriamente dito. Você sente, não num modo geral, é claro, você percebe, assim, trabalhos maravilhosos, mas você percebe que você tem que dar um apoio no letramento no quarto e quinto ano, agora também. Então já tá sendo, assim, proposta. Já estamos estudando no calendário a formação para o ano que vem para os quartos e quintos anos. Então eu volto naquela situação, conforme a gente vai verificando em visitas, no processo diagnóstico e outros instrumentos. Aqui, num diálogo entre os coordenadores, diretores, conforme a gente observa, a gente vai tentando fazer a formação daquela fragilidade que está mais aberrante, vamos dizer assim, nesse momento.

Entrevistadora: Como as escolas fazem a devolutiva do HTPC pra vocês, ou dessa formação que eles desenvolvem?

GMSA: Vamos começar do ler e escrever com os coordenadores...

Geralmente a gente dá, como se fosse uma "tarefinha", de uma situação problema que eles vão ter que ta levando na escola, desenvolvendo e no próximo encontro, socializando. Então essa devolutiva que a gente tem verificado, é nessa situação e também nas visitas pedagógicas que a gente faz.

Entrevistadora: Nas escolas?

GMSA: Nas escolas.

Entrevistadora: E a articulação com a sala de aula é isso que você falou, de levar pra sala e estar retornando?

GMSA: Isso.

Entrevistadora: Como proposta dos cursos?

GMSA: Só que os nossos cursos eles não são obrigatórios. Então os professores são convidados a participar. Então vamos falar dos avanços? No começo, quando foi 
oferecido o pró-letramento, eram 120 vagas. A adesão foi muito pequena. Isso, assim, a gente ficou muito triste. Como não era nada obrigatório, era só um convite, que pena, mas a gente tentou dar aquele pouco que tinha. Aderimos, para tentar fazer um trabalho legal. Como os professores fizeram e propagaram o que viram, em 2012 o número foi maior, de participação. Então, assim, pra mim que fui a tutora de 2011, a tutora de 2012 e estou sendo tutora agora em 2013, eu penso que foi uma avanço muito grande, porque nós sabemos, assim, existem professores abertos e querendo buscar e tal, mas existem professores que não tem tanta abertura, às vezes tem resistência ou às vezes eles estão com acúmulo de trabalho muito grande que não tem como fazer. Dou aula de manhã, dou aula à tarde, dou aula à noite. Aí chega no sábado, eles não conseguem. Nós tentamos de todas as formas, vamos fazer então durante a noite, que aí eles conseguem ir. Não, durante a noite tem gente que dá aula. Então vamos fazer num sábado. Aí esbarra porque tem gente que está fazendo pós-graduação. Então vamos pensar... onde vai atingir o maior número. Sabe? É fazer de sábado ou é fazer durante a semana? Tudo isso a gente tenta buscar pra poder favorecer a participação dos professores. Mas essa situação de ser convite, às vezes a gente fica com aquele ponto de interrogação. Até onde é bom ou não.

Entrevistadora: E o professor que não participa dessas formações, ele acaba tendo que fazer a formação só na escola, é isso?

GMSA: É ele tem o direcionamento dos coordenadores que a gente acredita que esteja passando, orientando. Nós temos um elo maior com os coordenadores, com os professores também, mas assim a gente busca subsidiar principalmente os coordenadores e os coordenadores em contrapartida nas escolas com os professores. Então é esse elo que a gente procura ter. E esses professores que não participam a gente fica esperando que pelo menos nessa reflexão proposta nas escolas, eles consigam estar indo num caminho que não fique tão diferente dos colegas. E nas visitas que a gente faz, nas visitas pedagógicas, a gente analisa, depois nós fazemos relatórios, nós conversamos, a gente volta, conversa com os professores, a gente busca fazer essa conversa individual. Então a gente pontua. Geralmente o que ele está direcionando de legal, assim bem dentro dessa proposta de alfabetização e letramento e quando a gente percebe fragilidade, vamos assim dizer, a gente faz sugestões, olha, aqui essa atividade, veja bem, seu objetivo, veja bem, você acha que essa atividade conseguiu atingir ou não? A gente pode direcionar se atingiu ou não? Por quê? Veja bem, será que se não fosse assim, assim, assado... Nossa! Eu não tinha pensado nisso! Nossa, legal! Então na próxima eu vou aplicar. Então eu penso que era isso. Aí você vai tentando convencê-lo, né, dentro de algumas fundamentações que seria interessante ou que viria atingir aquela expectativa, dos objetivos de uma forma que estivesse dentro desse processo de letramento. Tentamos. Tentamos, mas a gente sabe que temos que caminhar muito, muito. E as formações não só com eles, mas conosco. Então a cada ano que é oferecida formação pra gente também e que a gente também busca articular as concepções e a gente vem crescendo para um processo do qual a reflexão diária e as adequações a gente só consegue enxergar quando consegue parar, analisar, não ficar só na verificação apenas, mas verificação e uma tomada de decisão. Está assim, o que eu vou fazer daqui pra frente, como que eu vou direcionar o trabalho que atinja o quanto mais próximo possível a alfabetização e letramento.

Entrevistadora: Muito obrigada!

GMSA: De nada. 


\section{Gestora Escolar do Sistema A - GESA}

Entrevistadora: O município tem formação para os professores do ensino fundamental?

GESA: Tem. Os eventos acontecem quase o ano todo. Então eles contemplam os professores com cursos por área, pela área do atendimento, a educação infantil e o fundamental, e também tem o incentivo ao PNAIC, que eles fazem, a parte da alfabetização, o Ler e Escrever, Alfabetização e Letramento, que até o ano passado eles fizeram. Então, assim, oferecem bastante, e as professoras sempre estão aproveitando.

Entrevistadora: Quais são os formatos de formação. Cursos, palestras?

GESA: Nós temos cursos de curta duração. De trinta, sessenta horas. Cursos de 180, intermediário. E tem os cursos que eles fazem pelo sistema, são mais a longo prazo.

Entrevistadora: E essa formação que é desenvolvida, como é que ela chega na sua escola? Como é que você articula essa formação com o trabalho da sua escola?

GESA: Nós temos o período de HTPC e o HTPP. E tem uma vez por mês, uma vez a cada semestre as reuniões coletivas. Então todos esses espaços são aproveitados pra está orientando com relação aos cursos que elas estão fazendo, ou aproveitando pra está fazendo um estudo dos textos. Nós temos aqui na secretaria um encontro de 15 em 15 dias, uma reunião quinzenal entre as coordenadoras, que chama-se Ler e Escrever. Então elas entregam um material, a gente faz as análises, faz os estudos e a gente passa durante o mês com os professores nos horários de HTPCs. Então, os temas são variados: avaliação, a matemática, o ensino fundamental, a leitura e escrita, os gêneros textuais, então a gente vai trabalhando essa parte com os HTPCs e HTPP. O HTPP é individual, eu costumo receber as professoras na minha sala e faço o HTPP individual. As avaliações a gente procura fazer todo bimestre, a gente faz um acompanhamento das etapas em que as crianças se encontram nas construções de conhecimento, dos avanços, se vão tendo avanços, quais os tipos de dificuldades e existem os encaminhamentos. Então a gente tem os acompanhamentos do AEE e do reforço.

Entrevistadora: Só voltando um pouquinho à questão de como chega essa formação e como vocês desenvolvem. Vocês fazem esse encontro quinzenal. Que tipo de material vocês levam pra escola?

GESA: São as teorias, são os slides apresentados, os filmes que são assistidos na reunião, ou uma palestra gravado com alguma... Nós vemos bastante, nesse ano, a(*). Então todos os vídeos nós fomos assistindo e lá no HTPC, a gente assiste com os professores e faz uma releitura do que está acontecendo e faz uma relação com o que está acontecendo na escola. Relação, a partir dos textos.

Entrevistadora: De que forma vocês fazem a relação com a realidade da escola?

GESA: Então, todas as avaliações diagnósticas que a gente tem, nesse curso foi passado pra gente, alguns exemplos do texto, por exemplo, do bilhete. Como a gente vai analisar, como vai fazer a correção com o aluno, como vai acompanhar a estrutura do 
texto com o aluno. Isso é só o que nós fizemos aqui, aí nós fazemos lá (na escola) com os professores e os professores fizeram com os alunos.

Entrevistadora: Todo o HTPC, todo o trabalho de formação na escola ele é basicamente pautado por essas reuniões?

GESA: Por essas reuniões.

Entrevistadora: Só por isso?

GESA: Só por isso. A gente não tem um outro horário. As HTPPs, sim porque a gente vai desenvolvendo um trabalho de um por um, que a gente vai conversando.

Entrevistadora: Esse individual é um trabalho de formação ou é um trabalho mais de intervenção na prática do professor?

GESA: A gente faz um trabalho de formação e depois um trabalho de intervenção. Tem uns textos sugeridos relacionado com a turma que o professor tem de observação, de como trabalhar, de como poderia estar sendo trabalhado.

Entrevistadora: E lá, essa relação, existe alguma coisa que é prática, que vai pra sala de aula?

GESA: Não, tudo que a gente faz é visando a prática.

Entrevistadora: Sim, visando a prática, mas um, vamos dizer assim, há algo que é levado mesmo pra sala?

GESA: Nós trabalhamos no começo do primeiro semestre a matemática. Então nós trabalhamos um projeto de figurinhas. Pra eles compraram figurinhas, conhecer o dinheiro, conhecer a seqüência numérica. Então foi um projeto que foi levado daqui. E foi desenvolvido lá. Foi acompanhado, eu acompanhei o projeto, aí nós filmamos eles fazendo a apresentação, fazendo a coleção, colecionando as figurinhas, somando quanto tinha, a classe dividir pra poder comprar as figurinhas. Então, tudo o que é feito aqui é aplicado na sala de aula.

Entrevistadora: E vocês avaliam, fazem uma devolutiva pra secretaria desse trabalho da escola?

GESA: Temos, temos. As supervisoras e as orientadoras, elas visitam as escolas, né, e os nossos registros são feitos em semanários. Esses semanários têm todos os objetivos, todas as expectativas que foram estudadas e foram trabalhadas aqui com a gente, a gente trabalha com o professor e tem esse semanário. Aí elas vão e a gente conversa, discute sobre esse semanário. O que está bom, o que não está bom. Precisa às vezes mudar a organização e também o que valeu a pena, passa pros outros diretores, pros coordenadores.

Entrevistadora: Vocês têm alguma formação pra diretor?

GESA: Nós temos formação pra diretor e formação pra coordenador. Então eu participo de todos, porque eu exerço as duas funções.

Entrevistadora: E nessa formação pra diretor, o que é abordado?

GESA: A parte do diretor é realmente na parte de gestão, na parte de aplicação, né, de verbas. A parte mais administrativa, mesmo.

Entrevistadora: Em que momentos ela é realizada? Também quinzenalmente? 
GESA: Quinzenalmente. E o de coordenador também, quinzenalmente. Mas aí já é uma parte mais prática. Nessa última nós trouxemos os semanários. Então eram atividades da parte de leitura e escrita. Então nós trouxemos situações de aprendizagem que tava sendo desenvolvido, tava sendo trabalhado, no bilhete, aí nós analisamos tudo e passamos pra escola.

Entrevistadora: E avaliação externa, vocês tem alguma coisa específica. Prova Brasil... Há algum trabalho voltado especificamente pra esse tema?

GESA: A gente tem orientações. As supervisoras e as orientadoras elas passam orientações pra gente, da forma da aplicação, acompanham o processo e a gente passa para os professores. Então tem aquela parte de preparação. Eu, particularmente procuro preparar os professores nas reuniões, mostrando como são as avaliações, como vai ser a aplicação, quais as sistemáticas. Temos orientações para todos.

Entrevistadora: Vocês participam dos levantamentos dos temas a serem trabalhados nessas formações? A escola participa?

GESA: É por que a gente, no começo do ano, nas primeiras reuniões é o que vai, então a gente vai fazendo as reuniões pra estar elencando o que foi trabalhado. No ano passado, foi muito a parte de leitura. Então esse ano foi mais a parte de matemática e ciências também. A gente tem um grupo de estudo de ciências agora, a partir do meio do ano, a parte de ciências, então. No começo do ano, a gente já vai elencando junto com os orientadores tudo pra ser trabalhado durante o ano.

Entrevistadora: Está certo. É isso. Muito obrigada.

GESA: De nada.

\section{Coordenadora Pedagógica do Sistema A - CPSA}

Entrevistadora: fala pra gente sobre a formação continuada que é desenvolvida aqui no município. Como é essa formação?

CPSA: Bom, a formação é feita principalmente com as coordenadoras. Nós nos reunimos uma vez no mês com a equipe pedagógica, onde a gente vem trabalhando o projeto, o programa Ler e Escrever. A reflexão tem sido feita em cima do programa "ler e Escrever" dentro de Língua Portuguesa e de Matemática.

Entrevistadora: Que mais? Essa é basicamente a formação?

CPSA: Sim, que tem sido feita, sim. Não tem tido contato, por exemplo, com outros profissionais. Não há uma equipe de fora pra fazer o trabalho com a gente.

Entrevistadora: E como é o formato dessa formação? Como é com os coordenadores? Como isso é repassado pra vocês?

CPSA: Então. Há reflexão mesmo de textos, uma discussão entre o grupo dos textos que elas trazem. Esse é o esquema que elas têm montado. Desde já alguns anos isso. Faz tempo que a gente não tem, assim, outra formação com pessoas de fora. E a gente sente falta disso. Eu sinto falta. Eu acho assim. A rede precisava estar elaborando mesmo um programa de formação continuada. Eu acho que fica muito restrito quando você trabalha dentro da reflexão do próprio grupo, aquilo que os iguais pensam. Eu acho que fica muito dentro do igual. Não traz, a gente não tem uma formação de pessoas, que, por 
exemplo, que faz por exemplo um mestrado, que trabalha mesmo com essa visão. Eu sei que em (xx) vocês têm. Que há uma contratação de um profissional, que acompanha durante todo um ano, que traz esse tipo de reflexão. Nós não temos isso.

Entrevistadora: Como você descreveria esse "fica muito nesse igual"?

CPSA: Eu vejo assim: há pessoas que pesquisam, que estudam, que fazem a formação, por exemplo, se a gente falar: ah eu tive contatos, eu fui num congresso onde eu assisti a uma palestra com fulano de tal. Então eu tive.... Essa pessoa, a vida dela é um estudioso. Às vezes a gente fala assim, é muito teórico o que ele está dizendo, mas não é resultado de pesquisa mesmo, resultado de observações e você traz aquilo, você vai adequar aquilo pra sua realidade, pra dentro da sala de aula, pras dificuldades de seus alunos. Quando eu falo que é muito igual, são as nossas... é aquilo do dia-a-dia, elas fazem leitura. O programa Ler e Escrever: você lê, você tira noções. Elas participam de uma formação do programa, mas aí ela te traz aquilo como uma oportunidade mesmo de reflexão.

Entrevistadora: E chega como na escola?

CPSA: Eu preciso estar passando pro meu grupo de professores. E eu acabo passando da mesma forma. Ofereço os textos que foram lidos, sugestões de atividades. Então a gente trabalha mais em cima disso.

Entrevistadora: Sugerindo atividades e lendo os textos?

CPSA: É, lendo os textos, pontos de vista.

Entrevistadora: E como é a articulação desse formato com a prática, com a sala de aula? Você consegue ver essa articulação?

CPSA: Não, eu acho que sempre, toda vez lê um texto, toda vez que o professor, ele te traz questionamentos, às vezes uma atividade que ela aplicou e sentiu dificuldade, um aluno, olha foi muito legal desenvolver essa atividade, foi significativa a produção das crianças, ou não foi. Elas dão uma devolutiva. Há dentro do grupo bastante troca e fala de seu dia-a-dia. Vamos dizer das conquistas, do caminhar, olha deu certo, não deu certo. $\mathrm{Eu}$ acho que elas conseguem trazer, mas a rede municipal de nossa cidade precisa investir num programa de formação direto, para o professor e não deixar só a cargo da coordenadora ta levando pra dentro da escola. Por que eu acho assim, quando você faz... oferecem alguns cursos que são oferecidos, mas que nem todos participam.

Entrevistadora: Que cursos são esses?

CPSA: Por exemplo, agora, do próprio programa, o ano passado, eu me lembro que foi do... como chama? Do programa "Ler e Escrever", mas ... teve a formação em língua portuguesa e matemática.

Entrevistadora: Mas esses são aqueles cursos do Governo Federal...?

CPSA: Do governo, mas não cursos em nível de 180 horas ou de pós graduação que você faz, que também é passado pelas meninas da secretaria, coordenadoras.

Entrevistadora: Vocês participam de alguma forma, enquanto escola, enquanto professores, da discussão dessa formação, sobre os temas, sobre como conduzir essa formação no município?

CPSA: Não. Não. Também, assim, eu não tenho acesso ao que elas tem, o que é oferecido, eu acho que isso fica a cargo da própria equipe pedagógica, de estar 
decidindo, vendo os cursos que é acessível e que elas querem ta colocando à disposição, oferecendo.

Entrevistadora: Como a Secretaria acompanha essa formação lá na escola? Existe alguma forma de acompanhamento?

CPSA: Seriam visitas. Seriam visitas.

Entrevistadora: Na formação?

CPSA: Não, na formação, não, porque elas dão a formação. A equipe de orientação é que dá a formação. Por exemplo, o ano passado funcionou , inclusive foi usado o espaço da minha escola, com um grupo de professores, eram duas turmas, a (formadora) era responsável por um grupo e acho que a $(\mathrm{xx})$ era a responsável por outro grupo. Trabalharam portugueses e depois matemáticos. Então elas passaram pro grupo de professores que tiveram interesse e que fizeram adesão pra participar.

Entrevistadora: Então a articulação entre a secretaria e a escola, a produção dos professores, diretrizes da secretaria pra que vocês conduzam a formação, isso também não tem?

CPSA: Não.

Entrevistadora: Nem a avaliação dos professores em relação à própria formação? $\mathrm{O}$ que eu gostaria de saber é se há uma formação articulada, fora essa do Ler e Escrever, uma outra formação, um outro encaminhamento, uma outra proposta de formação pra que vocês desenvolvam enquanto equipe, enquanto rede?

CPSA: Não, não há.

Entrevistadora: Além desses programas, tem alguma outra coisa que você trabalha como formadora, vamos dizer assim, nos seus HTPCs?

CPSA: Eu procuro dentro das dificuldades do grupo, projetos que a gente, projetos, então nós vamos nos propor a desenvolver o projeto de matemática, porque eu observo que as crianças precisam trabalhar matemática conforme, através de jogos, então eu busco, por exemplo a leitura de um livro, de ler com as professores por etapa e ir discutindo também . Então assim, é aquela coisa, isso que eu te falo que vai ficando muito, vai ficando muito nas idéias daquele grupo mesmo.

Entrevistadora: Seria uma assessoria?

CPSA: É, não tem.

Entrevistadora: Vocês têm um currículo único na rede?

CPSA: Sim. São as expectativas de aprendizagem. São trabalhadas e isso foi organizado desde este ano, inclusive pra se trabalhar por bimestre, as expectativas mínimas pra serem trabalhadas em quase toda a rede.

Entrevistadora: Vocês fazem algum tipo de devolutiva escrita pra secretaria, através de relatório sobre a formação que você desenvolve na escola?

CPSA: Não. Não. Eu faço registro das HTPCs, da organização que eu faço com os professores. Em visita da supervisão ou da orientação pedagógica que elas solicitam ta olhando o trabalho. Esse é o tipo de acompanhamento.

Entrevistadora: É isso, obrigada. CPSA: Imagine. De nada. 


\section{SISTEMA B}

\section{Gestora Municipal do Sistema B - GMSB}

Entrevistadora: O município realiza formação de professores?

GMSB: Sim, nós realizamos. Eu vou passar as informações pra você em duas visões: Como professora e como formadora agora, que a gente faz esse acompanhamento por que eu estou nessa equipe desde o mês de agosto (2013). Então, sim, a Secretaria de Educação, a Prefeitura faz a formação continuada de diferentes formas: semanalmente, na reunião de coordenadores, cursos oferecidos para os professores e também grupos de estudo. Então, são diferentes formas de formação continuada.

Entrevistadora: Certo. Você poderia descrever cada um deles. Como é que eles acontecem?

GMSB: Ah, sim. A secretaria de Educação organiza de quinze em quinze dias a formação continuada para os coordenadores visando a formação dos professores. Então a Secretaria faz levantamentos no começo do ano, nós fizemos o levantamento das necessidades, da realidade da educação municipal naquele momento e fizemos a oferta de dois cursos naquele momento, um específico para leitura de $4^{\circ}$ e $5^{\circ}$ ano e o outro pra ensino de nove anos, que ainda é uma proposta que ainda causa bastante dúvidas nos professores. Então essa era uma necessidade daquele momento. Esses dois cursos foi mensal, na verdade foi uma carga de 30 horas quinzenal, esse foi quinzenal. Eu falei mensal por conta das turmas que eram dividas, mas foi quinzenal. Agora na formação com os coordenadores é quinzenal também. Em nível de secretaria, quinzenal. Então nós fazemos uma reunião com os coordenadores, de acordo com as necessidades que nós percebemos em toda a secretaria. Depois os coordenadores vão pras escolas e fazem uma reunião semanal. Quando eles percebem que há necessidade de que aquele assunto que foi discutido aqui na secretaria seja de interesse para os professores naquele momento eles já passam as informações, o curso e atende a necessidade. Caso contrário, não. Os coordenadores têm a liberdade de observar a realidade da escola dele e fazer o planejamento de acordo com a sua realidade. Este encontro então é semanal. Pros coordenadores nas escolas é semanal. Dos coordenadores com a equipe técnica, quinzenal. E temos também os cursos fora do horário de trabalho para professores, diretores, professores coordenadores. Então, tem mensal, de regularidade mensal, que é o grupo de estudo. Tem o de regularidade quinzenal e tem semanal também. Aí depende do cronograma.

Entrevistadora: Sobre esse curso, esses encontros que vocês realizam com os coordenadores: Que tipo de material, que tipo de proposta ele leva para a escola? Como ela está organizada?

GMSB: Nós fazemos principalmente aprofundamento teórico. Vou te dar um exemplo: Nós fizemos a prova do SAREM, que foi uma avaliação da secretaria, da rede, como estava. A partir dos dados levantados no SAREM, nós fizemos a análise das questões teoricamente e também demos o suporte teórico para análise de cada questão. Isso tudo, escrito, nesse primeiro momento. Agora nós tivemos outros momentos em que foi prático. Então preparação de material, por exemplo, o chamado HEC, os coordenadores 
de matemática, foi feito através de oficina, então os coordenadores tiveram condição de levar o material pra escola. Os vídeos, os slides que são organizados pela secretaria também são disponibilizados para os professores. Os textos que dão suporte teórico também são disponibilizados para os professores.

Entrevistadora: Certo. Então ele leva para a escola um conteúdo teórico?

GMSB: Um conteúdo teórico, quando nós percebemos que o enfoque é mais nesse sentido. Agora, quando é prático eles levam também os materiais que foram possíveis serem confeccionados, as idéias, os esquemas, o que for necessário naquele momento.

Entrevistadora: E o que vocês percebem na execução na escola? O que acontece na escola com essa proposta que vocês enviam, que vocês disponibilizam?

GMSB: Nós temos um acompanhamento da aplicação, da aplicabilidade dessas sugestões via relatórios do HEC -. Então nós percebemos que há um esforço dos professores coordenadores em provocar uma discussão na escola com os professores daquelas sugestões, daquelas discussões que são realizadas aqui na secretaria. Nós percebemos também que quando eles percebem que a realidade, a necessidade da escola é outra, eles informam os professores, apresentam os temas discutidos, porém eles vão pra aquilo que a escola tem mais necessidade naquele momento.

Entrevistadora: E vocês tem um acompanhamento sobre o quanto essas propostas são aplicadas e, em que medida, elas não são? Uma porcentagem de aplicabilidade, se tem escolas que aplicam ou seguem suas próprias diretrizes. Vocês têm esses dados?

GMSB: Não. Dado ou percentual e não tenho. Porém o que eu posso te afirmar pela leitura dos relatórios, nós percebemos que a grande maioria das escolas fazem. Tem essa preocupação de apresentar para os professores aquilo que foi discutido aqui na secretaria. Porém tem escolas, nós temos um exemplo de uma escola. Essa escola, especificamente que está aqui contigo, ela faz um trabalho sobre gramática, né, ortografia. Então, além daquilo que é discutido aqui na secretaria, então ela reserva um tempo pra apresentar aquilo que é discutida na secretaria e trabalha paralelo aquilo que ela se propôs a fazer. Nós temos uma outra escola que tem um acompanhamento da universidade, de um grupo de pesquisa da universidade. Então a professora da universidade que é coordenadora desse grupo de estudos vai pra escola. Agora eu sinto muito, mas eu não sei te informar a regularidade, mas vai pra escola pra fazer esse acompanhamento. Então durante o HEC é reservado um tempo pra informes, pra apresentação daquilo que foi discutido aqui e porém um outro momento pra esse estudo. Eu sei que é um estudo de leitura, a aplicação de estratégia de leitura no ensino fundamental.

Entrevistadora: Além dessa formação, me fale um pouco mais sobre os outros formatos de formação de professores que vocês desenvolvem.

GMSB: No primeiro semestre, nós tivemos esses dois que eu já te apresentei: o de estratégias de leitura, que foi destinado aos professores de $4^{\circ}$ e $5^{\circ}$ ano. Depois os de ensino de nove anos para os professores do primeiro ano. Esse era quinzenal e quem organizou foram os assistentes, os assistentes técnicos da equipe da secretaria mesmo. Neste semestre nós tivemos, estão acontecendo ainda dois cursos: Um de matemática, que uma professora mestre em educação formada pela Faculdade (XX). A secretaria acompanha, porém ela quem ministra, ela que elabora e nós participamos da discussão da elaboração. Porque nos percebemos que havia uma necessidade da rede de se discutir um pouco melhor as práticas, a teoria aliada á prática. Nós percebemos que a proposta 
da (professora especialista) consegue contemplar isso. Uma outra proposição é do curso de leitura e escrita, produção de textos, técnicas de produção de texto a partir dos projetos, da pedagogia de projetos, projetos de trabalho, metodologia de projetos, depende de como nós enxergamos, da base teóricas, mas é mesmo pensando no projeto. A escrita com a sua função social. Esse ministrado pela professora ( especialista). Também uma professora formada aqui pela universidade, da pós-graduação da universidade, doutora também em educação. Assim como o outro, ela elabora, ela pensou o curso e apresentou pra nós, e nós acompanhamos. Nós temos a orientação do professor (especialista), não sei se você conhece, ele trabalha com leitura e ele dá assessoria pra secretaria. $\mathrm{O}$ foco dele são as crianças da fase final do ensino infantil e do primeiro ano do ensino fundamental. Então ele vem acompanhando não foram todas as escolas contempladas do ensino fundamental, apenas três escolas e dois professores de cada escola, do primeiro ano. Então o professor (especialista) acompanha. Ele faz uma reunião, isso é mensal. Ele faz uma reunião com os professores aqui na secretaria, a equipe técnica acompanha e depois nós vamos pra escola, pra ver as condições em que estão sendo aplicadas as propostas dele.

Entrevistadora: Como vocês fazem esse acompanhamento?

GMSB: Nós vamos pra assistir a aplicação dos professores, como eles estão aplicando as propostas do professor (especialista), mas nós vamos mesmo pra conhecer, os assistentes, nós só vamos mesmo pra ver como está sendo aplicado e assessoria ao professor. Às vezes o professor precisa de um material, de uma organização diferente, uma conversa com a direção da escola. Então nós vamos pra dar essa assessoria.

Entrevistadora: Mas esse acompanhamento é durante o estudo?

GMSB: Por exemplo: o professor vem no mês de outubro, ele faz uma proposta. Retorna agora no mês de novembro. Então durante o mês de outubro nós procuramos dar assessoria a essa professora a esse professor que está em sala de aula pra ver as condições dele aplicar aquilo que o professor sugeriu, aquilo que foi realizado, o estudo que foi realizado no encontro. Quando o professor retorna, ele vai na escola, ele tem uma conversa conosco, aí ele vai pra escola, assiste à aula do professor, depois nós fazemos um momento de avaliação com aquele grupo e depois voltamos aqui pra secretaria pra fazer uma avaliação geral. São três grupos, porém a EMEF participa só de um. Os outros envolvem a EMEI.

Entrevistadora: Então já é uma proposta mais prática?

GMSB: Articula a prática. Um estudo teórico, ele faz esse estudo teórico aqui conosco, articulado à prática e também articulado ao ensino da educação infantil. Porque nossa proposta é que não seja fragmentar, não seja estanque. Então aconteceram as coisas no ensino infantil, pronto acabou: agora é ensino fundamental. Então a idéia é essa continuidade, por isso que nós temos essa união entre os professores de EMEI e de EMEF.

Entrevistadora: Certo. Isso pra três escolas?

GMSB: Pra três escolas de Emei, de Emef e 12 de Emei, que tem uma abrangência maior.

Entrevistadora: Esses estudos, essas outras formações contemplam a rede como um todo, todos os professores? 
GMSB: A primeira etapa não. A primeira etapa, a proposta do professor foi mesmo de fazer um..., como eu diria pra você? Analisar mesmo as condições, a aceitação, de aplicação de estudo, porque o professor (especialista) não quer que seja nada forçado. Vendo, nós fizemos uma avaliação das condições, dos resultados na primeira fase e já pensamos na segunda fase. Então nessa segunda fase o professor já pensa em envolver mais escolas e mais professores. Inclusive na próxima semana ele retorna e eu estou vendo com ele com alguns diretores a possibilidade de nós fazermos uma reunião com mais professores.

Entrevistadora: Essa proposta e esse retorno, vamos dizer assim, daquilo que vocês observam nessa formação com essas três escolas, é socializado de alguma forma com as demais escolas?

GMSB: Com as demais escolas não. Porém, com a escola com que os professores estão envolvidos, sim. Por quê? Porque nós temos a preocupação do aligeiramento. Porque às vezes, você faz uma proposta de atividade... isso acontece até no HEC, aqui com os coordenadores. Depois que vai pras escolas nós sempre fazemos um alerta pros coordenadores. Então, muitas vezes você faz um registro de atividade e quando você vai passar pro colega... Então você precisa ver se você tem todas aquelas condições, se você fez a apropriação de tudo pra fazer essa transmissão, ou mesmo passar pro colega. Então o prof. pede pra que por enquanto não. Na escola, sim. Na escola em que está sendo aplicado o projeto. Então o coordenador, o diretor, os outros professores companheiros que estão percebendo, que estão vendo a dinâmica na sala de aula, aí sim, passar, informar, mas com vagar, nada com uma preocupação de... apesar de o prof. dizer que agente tem o tempo pedagógico o tempo político, mas procurando mesmo se apropriar mesmo das propostas, pra depois nós passarmos pras outras turmas. Então, essa é a intenção agora na segunda fase. Envolver outros professores.

Entrevistadora: Essas outras formações, com exceção essa que você citou, que envolvem todos os professores, excetuando-se a que ocorre com os coordenadores e essas três escolas. Esses demais estudos envolvem todo mundo?

GMSB: Não. São destinados, por exemplo. O de leitura e escrita com a professora Stela Muller foi destinado aos professores de $4^{\circ}$ e $5^{\circ}$ ano. Porém é livre também, nós fazemos a oferta e o professor faz a inscrição. Se ele quiser participar, tudo bem. E quando há sobra de vagas, podem vir os professores dos outros anos. Esse é o público alvo. Por quê? Porque a intenção é: Nós analisamos os documentos, os HECs, e conversa com os professores, em conversa com os diretores mesmo, os professores coordenadores. Percebemos a dificuldade, aí nos fazemos a proposição. Nesse momento nós percebemos que havia necessidade pra esses anos, $4^{\circ}$ s e $5^{\circ} \mathrm{s}$ anos. Então por isso a proposição com a professora (especialista ).

Entrevistadora: Vocês têm formação pra outros segmentos como a Educação Infantil, creche?

GMSB: Tem

Entrevistadora: Como acontecem?

GMSB: Educação Infantil nós temos - e aí eu vou pegar uma colinha que eu trouxe aqui -

Entrevistadora: Claro 
GMSB: Como a estrutura organizacional é diferenciada, eles não tem os HECs. Então eles se organizaram de uma forma bastante interessante. Após o período de trabalho é oferecido aqui na secretaria palestras para os coordenadores, palestras para os professores também, para os diretores. Então tem palestras, tem oficinas, tem um momento de estudo também. Os professores... é interessante que tem uma quantidade de professores que participam também na universidade de grupos de estudo oferecidos na Universidade. Então na educação infantil tem também essa preocupação. Eu tenho aqui, não sei se você...

Entrevistadora: Ela vai me passar depois a relação

GMSB: Ah, ela vai te passar depois!? Então nós temos cursos, palestras, oficina e também na escola, uma vez por mês... isso eu não vou afirmar. Se é uma vez por mês ou é por bimestre, mas também tem esse momento de estudo para os professores. Provavelmente essa planilha de dados vai poder te informar melhor, mas há uma preocupação, Qual é a preocupação maior? Como nós estamos procurando esta integração entre Emei e Emef , então eu estou sempre "de orelha em pé" pra saber o que pessoal da Emei está conversando. Eles tem mesmo essa preocupação com a formação da criança, em pensar a criança enquanto criança, a criança enquanto sujeito das suas práticas, a criança enquanto um ser em desenvolvimento. E pensando um pouco em deixar a idéia de que é um brincar pelo brincar, vamos brincar porque educação infantil é brincadeira, sem uma organização dessa brincadeira, sem um lúdico pensado mesmo, um desenvolvimento da criança. Pensar sim, num brincar lúdico. Mas como o professor pode ser um mediador dessas atividades lúdicas, que a criança se sinta bem, porém que promova o desenvolvimento da criança. Já pensando na formação da subjetividade, enquanto sujeito autônomo, toda essa preocupação. Porque nós temos uma teoria que nos orienta. Quando a professora Fabiana nos convidou, ela nos convidou e já nos fez uma proposta porque ela tem um estudo, ela tem um embasamento teórico e fez essa proposta pra nós. Então nós temos a teoria históricocultural como embasamento teórico. Então nós procuramos mesmo. Quando nós fazemos a proposição para os professores-coordenadores, como para os professores, procuramos então pensar nesse sujeito que se desenvolve, mas já pensando nele enquanto sujeito autônomo, enquanto professor mediador. Toda essa questão do sujeito mesmo em desenvolvimento

Entrevistadora: Você acha que toda a formação desenvolvida é pautada por essa concepção?

GMSB: Nós procuramos apresentar sim. Inclusive para as pessoas que vem participar conosco na formação dos professores, nós procuramos trazer pessoas que dialogam conosco. Então, a professora (especialista), por exemplo, nós temos conhecimento de que ela tem um estudo na teoria histórico-cultural. A professora (especialista) ela tem uma proposta de projetos. Nós temos também a formação na área das tecnologias. Então uma preocupação, inclusive tem cursos para os professores de Emei e de Emef que o formador também vem com essa preocupação. Preocupação com os projetos. Envolver toda a turma, envolver o professor como mediador, mas o sujeito também em atividade. Todos os sujeitos em atividade.

Entrevistadora: Com relação ao currículo desenvolvido nas escolas de ensino fundamental, vocês tem um currículo único, um plano de ensino único, diretrizes curriculares? 
GMSB: Nós temos as diretrizes. Nós temos um projeto, mas só que aí cada escola vai fazer, organizar o seu projeto político pedagógico. Porém nós temos sim as propostas curriculares. A secretaria tem - eu não tenho aqui pra te mostrar -

Entrevistadora: Ela vai me fornecer

GMSB: Ela vai te fornecer?

Entrevistadora: Vai.

GMSB: Então nós temos aquela orientação que não é desvinculada daquilo que nós temos nos PCNs, que nós temos nas orientações oficiais, porém nós buscamos sim adequar à nossa realidade. Inclusive as nossas propostas, como nós estávamos falando da fundamentação teórica, então nós percebemos que em algum momento nós conseguimos perceber na fundamentação teórica dos documentos oficiais, por ex: o pacto pela educação. Então nós percebemos que o pacto pela educação, ele coaduna com aquilo que a secretaria propõe, que são os eixos de alfabetização que é a preocupação com a leitura, com a escrita com a informação social, que isso não seja aprendizagem pela aprendizagem, mas nos focarmos em ver qual é a função social da leitura. Então é uma proposta oficial do pacto, é um documento oficial, porém coaduna com aquilo que a secretaria nos coloca.

Entrevistadora: Em termos de diretrizes?

GMSB: Em termos de diretrizes

Entrevistadora: E vocês adotam algum material específico. Como é o material didático das escolas?

GMSB: Nós temos duas propostas: Uma é o semanário que o professor organiza. Então ele tem a proposta da prefeitura, depois ele tem o projeto político pedagógico da escola. Ele tem o plano das séries pra escola. Diante de todas essas informações ele vai organizar o seu semanário. Nós temos uma proposta onde o professor vai trabalhar com a realidade, não perdendo as diretrizes, mas trabalhando de acordo com as condições da sua sala. Sempre pensando mesmo no avanço da criança.

Entrevistadora: E o livro didático?

GMSB: O livro didático vem como suporte para o professor. E o professor vai optar. Vem sim os livros didáticos. Todas as turmas, todas as séries tem o livro didático.

Entrevistadora: Material apostilado a rede nunca utilizou?

GMSB: Não. Nós não adotamos apostilado. Para o ensino da matemática nós adotamos o AM (Atividades Matemáticas) - Também é oferecido para os professores.

Entrevistadora: Como vocês avaliam junto aos professores a formação que vocês desenvolvem?

GMSB: Nós buscamos sempre, é certo que tem sempre uma avaliação escrita que nós perguntamos aos professores o que eles gostaram, o que não gostaram, como nós podemos avançar... mas principalmente nós pedimos que eles vejam a aplicabilidade daquilo na sala deles. E depois nós...nada...olha na próxima semana do curso você me traz alguma coisa que você aplicou na sala. Não tem essa... nós não temos essa exigência, porém nós solicitamos: olha você fez... Vou exemplificar porque eu acho que fica mais fácil. A professora, no curso de matemática: ela fez uma proposta, fez uma 
discussão. O professor, ele vai pra sala e ele aplica na sala dele. Depois ele traz para o grupo e promove uma discussão no grupo. Então nós vemos que é possível e desperta interesse.

Entrevistadora: É uma proposta do curso aplicar, ou é uma iniciativa do professor em fazer a aplicação?

GMSB: Nós fazemos a sugestão. Sempre a sugestão. Olha, pra nós percebermos se dá certo ou não é preciso experimentar. Essa discussão... porque nós não podemos falar: olha não comi e não gostei. Não pode ser assim. Então nós temos que experimentar. E nós, nos cursos, nós procuramos oferecer cursos que tem uma prática bastante prática. Por quê? Porque nós percebemos que se o professor passa pelo processo de aprendizado de uma determinada atividade ele percebe as dificuldades que ele tem, ele vai conseguir orientar o aluno melhor. Então depois ele vai fazer a relação daquela atividade que ele desenvolveu com a atividade da criança. $\mathrm{O}$ orientador do curso normalmente promove uma discussão. "Como é que foi? Você gostou? Deu certo? Qual o resultado? Se for trabalho escrito, muitas vezes eles trazem o resultado pra nós vermos

Entrevistadora: Eles fazem uma produção escrita? É uma proposta se fazer uma produção escrita os cursos pelo próprio professor? Como é o registro esse conhecimento dele? Tem alguma forma?

GMSB: Não, é livre. Além dos documentos que os orientadores vão oferecendo, ele também tem a sua anotação. Agora, nos HECs, nas formações aqui que nós oferecemos na secretaria, é através do relatório do HEC mesmo. Como os professores do primeiro ano, eles enviam uma avaliação bimestral pra nós. De como foi, inclusive, as discussões dos HECs e também do curso de formação que eles tem. Agora os demais professores não. É sempre no final do curso, durante o curso. Aí vai depender de quem está organizando o curso. Posso exemplificar: eu ministrei curso no primeiro semestre. Então, ao final do dia, eu já conversei com os professores e perguntei, promovi com eles uma discussão sobre a possibilidade de aplicação daquelas atividades. No mesmo momento. Foi oralmente. No caso da professora (especialista), ela propõe que os professores apliquem na sala e depois traga o resultado dos alunos. Então...

Entrevistadora: Depende muito do formador?

GMSB: Depende do formador.

Entrevistadora: De que forma entra na formação de vocês as avaliações externas? Saresp, Prova Brasil? De que forma elas entram nos estudos dos professores?

GMSB: Como é o primeiro ano dessa equipe, nós tivemos, assim, um momento de grande revelação, mesmo pela aplicação do SAREM . Foi um momento muito bom pra reflexão, tanto da equipe pedagógica, quanto dos coordenadores. Como nós participamos de todo o processo. Desde a elaboração, até a correção e apresentação dos resultados para as escolas, nós tivemos condições de perceber que essas avaliações, nós também temos que observar todo o processo. Que não é possível nós nos apegarmos apenas a dados. Por quê? Porque nós temos uma porcentagem de uma determinada escola, mas aquilo vem refletir o todo de uma escola. Nós precisamos nos preocupar sim. Veio o dado da escola, nós temos aí um resumo de tudo. E como é que nós estamos vendo cada sala, cada turma. Qual foi o resultado em particular de cada sala, de cada turma. Então. É interessante nós termos o resultado externo, avaliações externas 
elaboradas por outras instâncias, instituições. É interessante sim, porém pra nós, pro nosso trabalho, como é que nós vamos pegar esses dados, esses resultados pra analisar a nossa realidade enquanto escola e cada professor na sua sala de aula. Como é que ele vai transferir essas informações pra prática dele. Então isso foi uma discussão bastante intensa e uma discussão no sentido de: eu tenho uma escola com uma porcentagem $\mathrm{x}$, porém isso reflete a realidade da minha escola. Então é um questionamento que nós lançamos para os diretores e para o professor. Essa realidade reflete realmente a realidade da minha sala de aula?

Entrevistadora: Você acha que esses resultados, de certa forma, direcionaram a formação de vocês?

GMSB: A proposição desses cursos?

Entrevistadora: Sim

GMSB: Não. Não direcionaram. Não direcionaram. A preocupação foi mesmo um levantamento da primeira etapa. Desse primeiro grupo, não de coordenação, mas da equipe mesmo da secretaria de educação. Quando essa equipe entrou, ela se preocupou mesmo em fazer um levantamento, um diagnóstico da realidade das escolas sem a preocupação com o SAREM, SARESP...

Entrevistadora: Diagnóstico seria uma consulta. É isso?

GMSB: É, uma consulta mesmo. De como estavam as escolas, da necessidade dos professores, pensando nas produções textuais, na função social da escrita, pensando mesmo: Será que isso está acontecendo nas escolas? Tá havendo uma preocupação dos professores com relação a isso? Nossa educação está voltada para o ensino técnico, mas sem reflexão do processo? Reflexão pelas crianças, pelos professores, pela coordenadora. Não um processo de reflexão do aprendizado só da equipe técnica. Ou só do grupo de coordenadores. Isso não pode. Na nossa concepção isso não pode acontecer. Tem que passar pelo professor, inclusive pela criança. Agora, como fazer isso? Então, como fazer isso, se você não tem o professor que não está capacitado pra fazer isso, então você tem que capacitar. Então foi essa a nossa preocupação inicial. E os reflexos disso na prova do SAREM foi também, qual foi a nossa avaliação? Então, diante dos resultados, o nosso professor, como é que ele trabalhou? É possível perceber isso na produção escrita? Nos resultados matemáticos. De acordo com as respostas das crianças. A estrutura do texto, vocabulário, o uso de vocabulário. A gramática textual. É possível perceber, é interessante. Essas informações estão sempre atuais

Entrevistadora: Você acha de diante do que o aluno apresentou nas avaliações você faz um diagnóstico do trabalho do professor?

GMSB: Não diria do trabalho do professor, somente. Não somente. Mas de toda a rede mesmo.

Entrevistadora: Toda a rede

GMSB: Toda a rede. De toda a estrutura

Entrevistadora: Daquilo que está chegando até o aluno?

GMSB: Daquilo que está chegando até o aluno. Porque nós não podemos pensar no professor sozinho em sala de aula. Nós sabemos que tem situações impares, que o professor, ele vai fazer e não é nenhuma questão de autonomia, às vezes é uma questão de resistência de uma nova proposta, às vezes é uma questão de autonomia também, 
mas, de um modo geral, é possível nós enquanto secretaria sabermos como é que essas orientações estão chegando, ou como que elas estão sendo aplicadas, se estão sendo aplicadas, como é que o aluno está se apropriando disso como o professor está se apropriando disso, como o próprio coordenador, nós também enquanto secretaria. Será que nós estamos falando de forma que esses professores entendam, esses coordenadores entendam? Por que tem a questão da autoridade e do autoritarismo. Então de repente nós estamos fazendo uma proposição que está sendo entendida como? Como uma autoridade no assunto ou como um autoritarismo, uma imposição. Então é uma preocupação da secretaria de que os professores se apropriem dessas proposições, internalizando mesmo...

Entrevistadora: Ele seria o sujeito?

GMSB: Tanto o aluno como o professor são sujeitos de aprendizagem. O professor pensando também na sua aprendizagem promove "ensinagem" mesmo.

Entrevistadora: Fala um pouco desse professor como sujeito de sua aprendizagem.

GMSB: Uma coisa que nos faz observar. Como é que o professor se entende enquanto sujeito, enquanto mediador, enquanto uma pessoa responsável mesmo pelo desenvolvimento do aluno. Será uma das nossas preocupações? Será que ele tá se enxergando mesmo nesse processo? Será que ele está se enxergando enquanto sujeito ativo, enquanto uma pessoa que vá promover toda essa mediação entre o conhecimento e o aluno? Então.. é preciso que ele se perceba uma pessoa também em processo de construção. Eu. Aí eu penso enquanto Assistente Técnica, eu não posso pensar em mim como uma pessoa pronta e preparada, com uma terminalidade. Mas se eu defendo e penso numa teoria que pensa no sujeito como apropriação de todo conhecimento histórico e social da humanidade, nós ainda estamos produzindo conhecimento. Então nós ainda estamos produzindo conhecimento, não só do sujeito, do sujeito pronto e acabado. Então eu também tenho que me envolver nessas novidades que vão surgindo. Então, é uma proposta também para os professores. Que eles também se percebam enquanto sujeitos em desenvolvimento. E para que eles possam desenvolver o desenvolvimento do outro, eu também preciso me apropriar dessas novidades. Então uma das propostas do ensino das tecnologias, das oficinas que são oferecidas pela secretaria, é essa a preocupação. Eu não posso pensar no ensino...nos dois processos de ensino e aprendizagem como algo pronto, olha, vai ser assim sempre e não vai ter alteração. Não, não é assim. Então, é... Não sei se respondi a sua pergunta?

Entrevistadora: Respondeu sim.

Acho que é isso. Obrigada!

\section{Gestora Escolar do Sistema B - GESB}

Entrevistadora: O município realiza formação de professores?

GESB: Sim.

Entrevistadora: De que forma? Qual o formato de formação que vocês têm aqui?

GESB: Como você mesma disse, vai mudando o governo, vai mudando a secretaria, vai mudando o formato. Nesses 14 anos que eu estou na rede já teve vários formatos. Logo 
no começo, quando eu entrei na rede, em 2000, a própria secretaria de educação tinha uma equipe montada: tinha uma professora de história, tinha uma que era responsável pelo ensino de ciências, tinha outro que era parte de língua portuguesa, tinha outro que era matemática e a própria equipe da secretaria montava os grupos de estudo com os professores. Foi logo que eu entrei, foi assim. Depois tem aqueles programas que vem do governo, eu tinha o... como se chamava? Progestão, antes do Progestão teve o próletramento, letra e vida, aquele de alfabetização que eu não estou (lembrada), o PROFA.

Entrevistadora: Sim.

GESB: Então esses programas foram implementados pela secretaria ao longo desses anos todos e a cada gestão foi mudando a maneira de montar a formação continuada dos professores. Independente disso, a gente, - uma opinião minha, individual - eu acredito que mais importante que isso é a formação que a gente faz dentro da escola porque a gente forma de acordo com a realidade da escola, da comunidade que se atende, da clientela que se atende, dos problemas que aparecem. A gente busca subsídio, às vezes, na secretaria, pra elaborar a formação continuada dentro da escola. Tanto com profissionais da secretaria, como com profissionais de fora da secretaria (interrupção entra mulher com o bolo). Eu acho muito importante a formação que acontece na escola que o diretor e o coordenador organiza, porque você direciona mais para o que o seu grupo precisa, os alunos precisam.

Entrevistadora: E essa formação que você diz que acontece na escola, como é essa busca na Secretaria? Esse auxílio?

GESB: Com profissionais da Secretaria, por exemplo: o prof. (assessor da secretaria) eu já convidei várias vezes, eu e outras escolas pra ir no HEC, o horário de estudo com os professores. A gente tem duas horas semanais, acho que lá vocês também têm?

Entrevistadora: Tem.

GESB: É... a gente busca, o prof. (assessor da secretaria), quando era aqui da equipe.

Entrevistadora: O professor (assessor da secretaria) também está nessa parte pedagógica?

GESB: Esse ano mudou. Nessa gestão mudou. Mas até a última gestão ele fazia parte, ele coordenava a equipe pedagógica, a parte pedagógica. Esse ano que ele saiu. E outros profissionais que estavam no grupo aqui, a gente chamava e eles iam. A maior parte das Secretárias também costumam reunir os diretores e perguntar o que vocês acham que está precisando de formação pros nossos professores. A (secretária atual) mesmo, nesse ano, no começo do ano, nos reuniu e perguntou o que é mais urgente pra gente elaborar cursos de capacitação pros nossos professores. Cada um deu seu parecer. Buscamos nas escolas, trouxemos na reunião e ela elencou as prioridades pro ano, de curso de capacitação.

Entrevistadora: E isso consultando os professores?

GESB: Consultou a gente, a gente consultou os professores na escola e trouxe pra ela.

Entrevistadora: Então esse planejamento, vamos dizer assim...

GESB: Perpassa pela necessidade da rede.

Entrevistadora: Esse levantamento é feito com base no que os professores dizem e no que os diretores também dizem de necessidade. 
GESB: Isso.

Entrevistadora: Existe algum outro tipo de diagnóstico da secretaria pra direcionar essa formação?

GESB: Sim. O tempo inteiro, diagnóstico o tempo inteiro acontece, porque a secretaria tem uma equipe que visita as escolas periodicamente, uma vez a cada bimestre, olha material de aluno, material de professor, vê o que está bom, o que não está. Se os índices de alfabetização não estão bons, os índices na matemática não estão bons. Isso também serve pra direcionar a formação continuada. E a gente tem o sistema de avaliação do município que é o SAREM, que eu comentei com você, lá.

Entrevistadora: Sim

GESB: É o sistema de avaliação do município que todo ano era aplicado em todos os quintos anos, agora passou a ser no terceiro e no quinto. Existe outro mecanismo de avaliação no município, por exemplo, que é uma prova feita no computador, informatizada, pros alunos de $4^{\circ}$ ano, então existem vários mecanismos de avaliação, de como estão as coisas e esse resultado é também pra programar os cursos de capacitação. A matemática está ruim na rede, vamos correr atrás.

Entrevistadora: Baseado também nos índices de avaliação externa, Prova Brasil?

GESB: Exatamente!

Entrevistadora: Vocês também fazem o SARESP?

GESB: Sim. Fazemos. É por adesão, mas o município todo ano adere. Esse ano a Fabiana optou por não aderir porque a gente tem... Ela optou por fazer assim: a gente tem o SAREM e a Prova Brasil. Então o ano que não tiver Prova Brasil nós vamos fazer SAREM e SARESP. O ano que tiver a prova Brasil, nós vamos fazer SAREM e PROVA BRASIL. Pra não ficar três avaliações no ano.

Entrevistadora: Um excesso de avaliações...

GESB: E também as coordenadoras das escolas têm reunião aqui, quinzenalmente, com a equipe pedagógica. E através delas também são levantadas as necessidades das escolas, de formação para os professores.

Entrevistadora: Então há por parte das secretarias um direcionamento desses HTPCs (HECs)?

GESB: Há, sim.

Entrevistadora: De que forma?

GESB: Pros HECs eles fornecem bastantes subsídios, bastante material. Fazem estudo com as coordenadoras pra prepará-las pra elas fazerem lá no HEC com os professores. Agora, não é obrigado. Por exemplo, a minha coordenadora, ela vem aqui, ela participa da reunião, ela participa do estudo, e o estudo foi sobre matemática. Só que na minha escola nós não estamos com problema em matemática, estamos com problema em ortografia, então a gente não é obrigado a estudar matemática no HEC. A gente pode elencar lá na escola, então a formação é dada aqui de acordo com a maioria, de acordo com a necessidade do município. Agora lá na escola a gente tem autonomia pra direcionar os estudos lá, pra o problema que ocorrendo na escola.

Entrevistadora: Que tipo de material e que tipo de proposta vão pra escola? 
GESB: Normalmente textos pra estudo. Normalmente. Vídeos, textos e também são organizados, por exemplo: Capacitação para os professores de $5^{\circ}$ ano. Então em dia de HEC, ao invés dos professores fazerem o horário na escola, fazem o HEC aqui na secretaria numa formação. Então depois, acabou os $5^{\circ} \mathrm{s}$ anos, começam com os $4^{\circ} \mathrm{s}$ anos, $3^{\circ}$ s... Então naquele dia os professores do terceiro ano da rede inteira se encontram. Já teve isso também. $\mathrm{O}$ ano passado já teve isso.

Entrevistadora: E quando essa proposta chega. De que forma ela é desenvolvida na escola? Como vocês, pegando essa proposta que é da secretaria, que vão os textos, como é que vocês desenvolvem isso na escola?

GESB: Dificilmente coincide de que o que está sendo estudado aqui seja o que está sendo estudado lá. A gente é muito pé no chão, a gente avalia a nossa escola o tempo inteiro. O tempo inteiro, o tempo inteiro, o tempo inteiro. A minha coordenadora e eu, particularmente, temos uma sintonia de trabalho muito grande. Nós começamos a nossa carreira juntas, no SESI. Trabalhamos 12 anos juntas no SESI, depois eu vim pra rede e ela veio também, então a gente tem uma sintonia, uma maneira de trabalhar muito parecida. Então a gente busca muito, assim, nos alunos, na sala de aula, nos cadernos, nos textos, o que está precisando. Diariamente a gente avalia. Nosso diagnóstico é diário. A gente tem muita clareza do que a gente precisa correr atrás. E vai emendando uma coisa com a outra, sabe assim, o tempo de estudo não é suficiente pra estudar tudo o que a gente acha que é preciso estudar na escola. Dificilmente a gente quebra isso que a gente tem lá, dificilmente. Então agora a secretaria começou a trabalhar tal coisa, ah, então nós vamos parar? A gente já tem mais ou menos uma sequência do que precisa pro ano inteiro.

Entrevistadora: Entendi. Então você acha que difere?

GESB: Eu estou falando da minha realidade. Tem escolas que abraça com as duas mãos e leva.

Entrevistadora: Entendi.

GESB: E põe, e usa e é bom e dá resultado. Mas eu tenho uma, digamos, uma autonomia, não sei, em relação a isso. Por que a gente tem uma identidade já, muito forte.

Entrevistadora: E a Secretaria dá essa autonomia?

GESB: Dá essa autonomia. Conquistada. Assim, essa credibilidade que a gente ganhou em 14 anos, nós conquistamos. Conquistamos essa credibilidade por que todos que já passaram por aqui assistem assim o tanto que a gente se empenha. $\mathrm{O}$ resultado que a gente consegue. A credibilidade com a comunidade, com a nossa clientela, então tudo isso.

Entrevistadora: Então você pode dizer assim que essa autonomia conquistada se dá pelo fato que o estudo proposto pela secretaria é teórico demais para a sua escola? Seria isso?

GESB: O que a secretaria propõe?

Entrevistadora: Isso.

GESB: Não. Eu acho que é o momento que chega, às vezes não coincide com o momento que a gente está vivendo na escola. Só isso. 
Entrevistadora: Entendi.

GESB: É o momento. Não que não sirva pra escola. Às vezes esse material é guardado e no momento que eu vou estudar aquele assunto, a gente usa também, busca aqui, vídeo, material, bibliografia. Eu só digo assim que o momento... a secretaria não faz o meu momento lá. Esse momento é nosso, próprio. Nós temos lá a nossa sequência.

Entrevistadora: E você, na sua escola, como você desenvolve essas propostas de formação de professores. Você organiza de que forma o seu estudo? Como ele está estruturado?

GESB: Você pergunta assim, a estrutura do HEC?

Entrevistadora: Isso.

GESB: O estudo, oficina de trabalho com os professores. Além do estudo teórico a gente parte para a prática.

Entrevistadora: De que forma vocês partem para a prática?

GESB: Oficinas com os professores. Eles participam ativamente fazendo. Não só estudando teoricamente. A gente pratica, por exemplo, eu vou te dar um exemplo. A gente está trabalhando com estratégias de leitura: síntese e sumarização, antecipação, conhecimento prévio, estratégias de leitura. Então, além da gente estudar o material teórico, depois a coordenadora pratica aquilo com os professores, ela faz a prática pros professores assistirem e depois ela lança um livro, uma sugestão pro professor preparar para o próximo HEC e ele apresenta em forma de oficina. Ele fazendo com o grupo.

Entrevistadora: E ele faz com o grupo?

GESB: Sim

Entrevistadora: E tem alguma articulação com a sala de aula?

GESB: Sim. Ele também aplica na sala de aula e traz o resultado que ele aplicou. Ele traz o material que ele usou na sala de aula. Às vezes ele não precisa nem preparar aquilo porque ele já aplicou, ele já está aplicando, de acordo com os estudos. Então ele já traz pra mostrar. Tem todo um casamento.

Entrevistadora: Sobre esse formato. Você acha que tem também uma proposta da secretaria que incentiva esse formato?

GESB: Eu acho que sim, porque a gente envia mensalmente relatórios dos HECs para a secretaria. Então eles ficam sabendo como é que funciona o estudo na escola. Isso também nos dá autonomia, porque eles estão vendo o que eu não estou estudando o que a secretaria deu, mas que eu tenho um estudo e aprofundado. E normalmente tem sido aprovado. Assim, elogiado. Então, a gente aprofunda, a gente dá seqüência, a gente não lê um texto por semana, diferente, que não tem nada a ver.

Entrevistadora: Mas vamos supor que você ou que as escolas que aderissem à proposta da secretaria, ela pegaria os textos, então. Ela não pegaria uma proposta toda como essa que você tem?

GESB: É. Acho que sim. É mais um aprofundamento teórico. Mais um aprofundamento teórico no assunto.

Entrevistadora: E durante o processo. Voltando um pouquinho a toda essa formação do município. Como é avaliado todo esse processo pela secretaria. Como é que a 
secretaria avalia. Como é que a avaliação da formação continuada é feita por vocês, lá na escola?

GESB: Desculpa. Eu não entendi.

Entrevistadora: Vocês avaliam a formação continuada do município?

GESB: Não tem um momento que a gente avalia. No final do ano a gente recebe um cd com a avaliação institucional pra escola responder. Nessa avaliação, constam todos os cursos que foram oferecidos pela secretaria no ano e qual foi a adesão da minha escola. Quantos professores fizeram, gostaram ou não gostaram. Foi bom ou não foi. Isso no final do ano. Mais ou menos isso que você queria saber?

Entrevistadora: Isso. E a secretaria avalia, tem algum tipo de acompanhamento da secretaria em relação à formação? Do que acontece na escola?

GESB: Sim. Esse relatório de HEC que eu mando. Por ali eles ficam sabendo o que eu estudei na escola com os meus professores.

Entrevistadora: Então você mandou o quê, por exemplo?

GESB: Mensalmente... deve ter algum aí.. depois eu pego pra você, se você quiser... A gente faz um relatório, como por exemplo. É toda quinta-feira...

Entrevistadora: Isso é uma diretriz da secretaria? Você tem que enviar?

GESB: Eu tenho que enviar. No quinto dia útil eu mando do mês que acabou, os quatro relatórios, normalmente são quatro semanas, quatro quintas-feiras no mês. Então eu mando os quatro relatórios e na nossa escola, a gente, a minha coordenadora é muito minuciosa e a gente encaderna o relatório.

Entrevistadora: Tudo que vocês fizeram de formação?

GESB: É. Além de descrever qual foi o objetivo, como foi o desenvolvimento, quais foram os conteúdos, quais os textos estudados a gente põe em anexo, as atividades que a gente envolveu em oficina, ela recolhe de todos os professores e anexa, com a letra dos professores ela costuma anexar. Então, quem lê aqui tem clareza do que está sendo estudado na escola. Até as reflexões que os professores fizeram constam nesse relatório. Depois eu vou pegar um pra você olhar.

Entrevistadora: Eu até vou solicitar, se ela puder me fornecer...

$\mathrm{Eu}$ acho que é isso. A gente conversou sobre a forma de pensar, o planejamento, o acompanhamento e a avaliação.

GESB: Exatamente.

Entrevistadora: A formação, na sua opinião, desenvolvida por vocês ou pela secretaria, tem algum retorno na atitude profissional desses professores?

GESB: Tem. Eu vou te dizer por quê. Eu entrei em 2000. De 2000 a 2006, mais ou menos, a gente estudava sempre nessa coisa de levar bons textos, estudos aprofundados pro HEC e tal, só que eu não via melhorar os resultados da escola. Meu marco divisor foi em 2006 quando saiu o resultado da prova Brasil de 2005 é que eu vim pra reunião. Costuma demorar pra sair o IDEB. Então em 2006 quando saiu, acho que foi o primeiro IDEB, em 2005. A minha escola estava com 5,2. Eu me afundei na cadeira, assim, eu nunca vou me esquecer. Uma vergonha e me eu lembro que eu me perguntei, Meu Deus! O que estou fazendo de errado, que a minha escola está indo tão mal? Tinha ficado abaixo da média do município. Com tudo isso que a gente estuda! Meus 
professores, assim, eu tenho um perfil de grupo lá de pessoas responsáveis, na sua grande maioria são pessoas que arregaçam a manga e que querem ver acontecer. O meu grupo tem esse perfil, sempre teve. Quem não é assim acaba não ficando lá, acaba indo embora na remoção. Ou eu convido, ou eu dou uma indireta, ou a pessoa se enche de mim, da minha cobrança e vai embora por si só. Então o meu grupo tem esse perfil. E quando foi em 2006 que saiu essa nota, eu desesperei, eu vim aqui e falei com o professor (assessor da secretaria). Falei pro professor: Me ajuda, o que eu to fazendo de errado? Eu tenho um grupo bom, meu grupo é responsável, meu grupo quer que as coisas aconteçam. Eu quero que as coisas aconteçam, eu não tenho ninguém preguiçoso lá, ninguém irresponsável. O senhor vê os relatórios de HEC, nossos estudos são textos bons, são aprofundamentos de estudo e a gente não ta conseguindo resultado. Aí ele falou assim: (diretora), tudo isso que você falou é verdade. Então ele falou assim também: o que está faltando é você ver assim: o que está sendo estudado e aprofundado no HEC, teorizado...o professor está conseguindo transpor todo dia lá pra sala de aula dele? Eu não me esqueço que ele falou assim: Quando você ensina uma criança a atravessar a rua e ela tem que olhar pros lados, você ensinou, mas você não pode soltar, você tem que ir do lado dela e falar: você já olhou pra lá, você já olhou pra cá? Se não ela vai esquecer e não vai toda vez olhar pros dois lados. A partir daí, 2006, começo de 2007 eu comecei a trabalhar na escola com rotinas didáticas. Então, todo estudo que a gente, estudava, buscava... Um exemplo: etapas de produção de texto, chamei o professor (XX), chamei a (professora especialista da universidade), então ela foi lá. A nossa escola foi a primeira a trabalhar com etapas de produção de texto, com revisão de texto. Então eu comecei, tudo o que a gente aprofunda e estuda, todo mundo estuda e participa, a gente formata uma opinião, um consenso de que aquilo vai ser bom, a gente transforma em rotina. É uma rotina da escola, semanalmente, quinzenalmente, aquilo tem que acontecer.

Entrevistadora: Sai, de certa forma, do estudo e vai pro dia-a-dia?

GESB: Exatamente. Ele vira um documento de rotinas didáticas, que todo começo de ano a gente aprimora e refaz. Então na proposta pedagógica a gente refaz esse documento. Então, por exemplo, em língua portuguesa, a gente tem a etapa de produção, a gente tem a parte de leitura, a gente tem as rotinas, horas de leitura tantas vezes na semana, roda de leitura tantas vezes na semana, círculo literário, que é um material que a gente produz pra criança ter apoio de leitura. Então tudo isso, de acordo com estudos de leitura, a gente criou rotinas de leitura. Estudos de ortografia agora, que a gente está terminando de encerrar. Eu chamei a (especialista da universidade), então em dois anos seguidos ela foi pra escola pra fazer um trabalho de ortografia com a gente. Depois a coordenadora dá o fechamento dela e vai criando com os professores a rotina em cima daquilo. Então o que é que vai ficar pra nós por ano. Primeiro ano vai fazer isso, segundo ano isso. É transformado em um documento e a minha coordenadora que é mais "muié do piolho" que eu ainda, ela cria um documento pra análise do semanário. Então quando ela vai ler o semanário (eu não sei se eu to respondendo ou não, não sei se interessa isso?)

Entrevistadora: Muito. Pode continuar

GESB: Ela tem uma ficha de leitura do semanário. O semanário é o planejamento que a professora faz semanalmente. Na terça-feira todo mundo entrega e ela lê o semanário pra ver o que foi planejado pra aquela semana e ela faz essa leitura e ela marca na ficha dela. Ela tem a ficha do primeiro ano, quais são as rotinas didáticas do primeiro ano. Então ela olha pra ver se o professor está cumprindo. Ah, se nessa semana ele não 
cumpriu, na próxima semana ela olha de novo. Ah, na semana passada ele não cumpriu, por que será que nessa semana ele não cumpriu de novo? Então ela chama o professor e pergunta. Então ela faz um acompanhamento sistematizado pra ver se o professor está cumprindo o que foi combinado pra ele fazer.

Entrevistadora: E ela faz algum acompanhamento em sala?

GESB: Visita

Entrevistadora: Como são as visitas dela?

GESB: Ela tenta, é que é difícil porque é um acúmulo. O coordenador é a pessoa que mais trabalha na escola é o coordenador. Ela tenta, na semana pelo menos fazer duas visitas, duas de manhã e duas à tarde. Então ela passa pra eles, olha esse mês eu vou tal, tal, tal, vou nos primeiros, depois nos segundos. Ela entra na sala e fica lá, ela também tem uma ficha, na visita ela já aproveita e ela já olha os cadernos dos alunos, pra ver se aquilo que está no semanário do professor. Está nos cadernos dos alunos, ela olha a produção de textos dos alunos, se condiz com que o professor ta falando, então tem essa visita também, ela é bem sistemática, nós somos duas controladoras.

Entrevistadora: E vocês são duas na equipe? É o diretor e o coordenador?

GESB: E a vice.

Entrevistadora: Ah, tem a vice. A vice faz algum tipo de trabalho pedagógico?

GESB: Ela ajuda. Ela ajuda a coordenadora a preparar material pro HEC.

Entrevistadora: Como é a sua participação e a participação da vice-diretora na elaboração da formação dos professores?

GESB: Tudo junto, nós três.

Entrevistadora: E nos encontros, como é a sua presença?

GESB: Tudo, nós três! Tudo, o tempo inteiro, nos HECs nós estamos presentes. A Vânia ela vai fazendo registrando tudo que vai acontecendo pra ajudar no relatório de HEC, ela ajuda a coordenadora a fazer, então ela fica como escriba ali, e nós três. $\mathrm{O}$ pedagógico na nossa escola, a parte que eu mais gosto é o pedagógico. Eu não nasci pra ser diretora eu nasci pra ser coordenadora. Mas sou diretora a parte que eu mais gosto é o pedagógico. Às vezes eu acho até que sou negligente em outras partes em função do pedagógico. Já teve ocasiões de tirar a funcionária da limpeza, mas ela tinha curso de pedagogia, tirava ela da limpeza e colocava ela na sala de aula pra ajudar o professor. Então o meu foco...eu prefiro que a escola não fique tão limpa, mas que o pedagógico ande. Então eu, a coordenadora e a vice estamos sempre juntas, as três. Nenhuma das três é administrativa, as três o foco é pedagógico, é lógico que eu cuido da parte administrativa a contendo, mas não é o que eu gosto.

Entrevistadora: Obrigada.

GESB: É isso? De nada. 


\section{Coordenadora Pedagógica do Sistema B - CPSB}

Entrevistadora: O município realiza formação de professores? CPSB: Sim.

Entrevistadora: Qual é o formato da formação?

CPSB: Ela existe quinzenalmente para coordenadores, que é uma reunião onde também tem a parte de formação e ela acontece também para os professores. Ela é mais esporádica, mas ela também acontece a cada mês ou a cada bimestre, sempre tem a formação de acordo com a temática que o município detecta através dos dados coletados a necessidade da região.

Entrevistadora: Certo. E esses encontros? Fale sobre esses encontros com os coordenadores e como é que essa formação, isso que vocês estudam chega na escola?

CPSB: Ah, sim. Os encontros com os coordenadores acontecem quinzenalmente. Toda segunda segunda-feira do mês acontece e é ministrado pela supervisora de ensino junto com a sua equipe. Nesses encontros, o que acontece: passam-se as orientações e ministram os cursos de acordo com a necessidade da rede. Por exemplo, agora a gente ta vendo a questão dos dados do SAREM e junto com ele um foco sobre a questão da gramática, nesse último que a gente fez, mas desde o início do ano, foi passado por (enes) assuntos: sobre fração, que era uma das dificuldades da rede, como um todo, foi passado também um estudo sobre o encaminhamento da leitura. Então são vários os temas que eles vão detectando através dos dados que a escola fornece, da secretaria, das escolas como um todo e desses dados eles montam pra gente a formação. Passada a formação pra gente, o coordenador repassa pra escola nos encontros semanais que a gente tem que são os horários de estudos coletivos, que é o HEC. Toda semana a gente tem duas horas de HEC, Horário de Estudo Coletivo. Nesses encontros o que é priorizado? Passam-se os recados administrativos em termos de secretaria e de unidade escolar, e o outro tempo é destinado somente ao estudo, estudo de referenciais teóricos que a escola necessita, bem como o que a secretaria passa pra gente. Então a gente prioriza os dois momentos. Além disso, essa formação passada pra gente, que é o coordenador repassando pra escola, a gente também tem a parte de socialização, onde os professores colocam em prática aquilo que é falado em reunião, aquilo que é estudado nos referenciais, e eles socializam como é que foi essa prática. Nesse momento também tem essa abertura pra eles nos HECs.

Entrevistadora: Certo. Então nos HECs vocês tem, vamos dizer assim, você leva isso pra prática, e essa é uma proposta de levar para a prática que já vem da secretaria, ou isso é uma escolha da escola?

CPSB: Algumas coisas a gente tenta no convencimento. Por exemplo, quando a gente vê que tem algum professor que está precisando de alguma ajuda, de uma intervenção, a gente procura dar mais formação, mais ênfase naquilo procurando convencê-lo que um trabalho mais eficaz. Então não seria imposto nem pela secretaria, nem por nós. É uma questão de convencimento e de necessidade. Então eles vêem através dos resultados que precisa de uma mudança, que precisa de alguma coisa. Então através do convencimento.

Entrevistadora: Certo. Então quando você recebe, você leva essa proposta de formação da secretaria que vai pra escola. Como é que essa proposta vai? Ela vai de que forma? Ela vai formatada da forma como você deve fazer com os textos e os referenciais. De que forma ela chega pra você, como coordenadora? 
CPSB: Primeiro a gente vai elo referencial teórico, pelo estudo. Depois a gente vai mesmo pra parte prática, de análise de casos, de análise de situações, e aí eles vão tentar fazer, aplicar. Aquele que se sente possuído daquele conhecimento. Aqueles que se sentem à vontade vão, aplicam. Deu resultado, ele vem, socializa e isso já é um estímulo pro outro.

Entrevistadora: Então não está assim, sistematizado como uma regra, uma rotina de que eu levo isso e a partir disso eu faço. Eu tenho um desdobramento de práticas lá, você tem autonomia de organizar da forma como você achar melhor.

CPSB: Sim. Tanto nós como até o próprio professor. Enquanto ele não tiver aquilo absorvido, incorporado, ele ainda não... assim que ele conseguir ele faz a prática dele, não é uma coisa obrigada.

Entrevistadora: Da secretaria vocês levam basicamente textos, então?

CPSB: Textos e algumas práticas também.

Entrevistadora: Que práticas vocês levam daqui (da secretaria)?

CPSB: Bastantes exemplos que elas mostram pra gente de como intervir de como fazer em determinado assunto. Tudo isso é repassado. E aí não adianta uma ou duas vezes, tem que ser uma coisa constante, um ir e vir. Então está sempre retomando, sempre falando. Então isso faz com que o professor, pelo menos é a minha visão, que ele vá criando mais cautela no que ele tem pra fazer e aos poucos ele vai incorporando. Não digo $100 \%$, mas a grande maioria aos poucos eles vão passando, nada imposto e sim oferecido.

Entrevistadora: Então a hora de trabalho pedagógica na escola basicamente, na sua escola, por essas diretrizes da secretaria?

CPSB: Também. É que a gente sempre procura enfatizar as necessidades da escola. Então tem assuntos abordados aqui que por enquanto a escola não ta com dificuldade. Por exemplo, o do começo do ano que foi fração, eu não entrei nesse assunto porque não era uma necessidade da escola. Então eu só comentei o que foi passado aqui, porém a gente não fez um estudo aprofundado. Então os outros assuntos em relação às dificuldades apresentadas nas avaliações externas é algo que eu priorizei pra elas. Então análises, as dificuldades, aí sim eu repasso a gente faz um estudo aprofundado de teoria, prática e reflexão. Tem assuntos que é passado aqui, que eu repasso, mas não com aprofundamento.

Entrevistadora: De que forma você repassa?

CPSB: Sempre é informado como foi a reunião. Então aí eu falo, olha, falou-se sobre isso, isso, isso. Nesse momento nós vamos priorizar isso, em detrimento do que foi a necessidade de nossa escola através disso, disso, disso... Então fica muito claro pra eles porque daquele assunto.

Entrevistadora: E vocês têm algum documento, algo que vocês tenham que prestar conta dessa forma de organizar os (HECs), da forma de estudo que você tem na escola. Isso você devolve pra secretaria de alguma forma?

CPSB: Sim através dos relatórios de HEC é passado tudo como é que a gente faz.

Entrevistadora: O que tem que ter nesse relatório? 
CPSB: Tem que ter o tema do assunto do dia, ele tem que ter os objetivos do porque que eu quero trabalhar aquele assunto, outra parte que tem os assuntos administrativos que é tanto em nível de secretaria quanto em nível de escola, muitas vezes em algumas circulares que a gente tem que repassar até mesmo oferecendo algum curso para os professores é priorizado no momento, são os administrativos. E um segundo momento que é o pedagógico, que em média dá um a hora, uma hora e meia de estudo. E é aí onde a gente se detém no tema de estudo que a gente se propôs.

Entrevistadora: E os temas? Que temas permeiam a formação continuada do município? Você me disse que tem esse estudo e que tem outras formações proporcionadas para os professores. Fala um pouco dessa formação: dos temas e como ela acontece.

CPSB: Ela acontece, como eu já falei através da necessidade da rede, em nível de secretaria. Então neste ano, falou-se bastante da questão da fração, no começo do ano. Também do ensino e do encaminhamento do questionamento de texto.

Entrevistadora: Isso é não é uma formação de estudos dentro da escola?

CPSB: Então. Algumas coisas desses assuntos são levados à escola também.

Entrevistadora: Eu quero saber em termos de outros tipos de formação que não seja essa do estudo da escola. Existe uma outra formação que é realizada pelo município, que vocês participam, como é isso?

CPSB: Sim, por exemplo, tem as parcerias com as universidades, como a diretora comentou. Então, a gente participa. Tem uma professora e eu enquanto coordenadora, participamos de uma formação para crianças com autismo. Então vem uma professora da universidade, Doutora (XX), que a cada mês ela vem falar e fazer estudos de caso a respeito do trabalho com os autistas.

Entrevistadora: Com os professores?

CPSB: O professor que trabalha com essa criança.

Entrevistadora: Certo.

CPSB: Tem o professor e o coordenador participa também. Tem o da (professora especialista), que é sobre a deficiência auditiva. Então é disponibilizado também. A professora vem, conversa, faz os estudos de caso, tem todo um estudo em cima. Também tema parceria com a universidade em relação aos estudos da questão dos gêneros textuais, que acabou agora. Então, também tem esse.

Entrevistadora: Isso pra todos os professores?

CPSB: Foi oferecido para os de $4^{\circ}$ e $5^{\circ}$ ano, mas agora vai ser oferecido para os coordenadores também. Então o que acontece? Esses professores que participam desses cursos, eles também tem espaço no HEC pra socializar. Tudo o que foi passado, de uma forma mais simplificada, eles dão retorno para os outros professores. Então teve o de matemática também no início do ano, com um professor da universidade também. Sempre é disponibilizado. Então tem um outro também com uma doutora, em matemática, para os professores de $3^{\circ}$ e $4^{\circ}$ ano. Os professores de $1^{\circ}$ e $2^{\circ}$ ano tem o Pacto que o município faz parte.

Entrevistadora: Sua escola tem educação infantil? 
CPSB: Não. Só ensino fundamental. Então assim, nossa escola, a gente prioriza muito isso, os cursos que os professores fazem fora, tanto o professor, quanto o coordenador, a gente procura trabalhar esse conjunto de troca mesmo, de socializar, de passar. E o que é mais gritante na escola a gente foca num estudo mais teórico, mais definição teórica, mais reflexivo e prática junto. Então, algumas vezes casa com esse da secretaria, às vezes não.

Entrevistadora: E vocês têm um acompanhamento da secretaria, além desse documento, tem alguma outra forma que a secretaria acompanha essa formação de vocês?

CPSB: Então, tem os relatórios de HEC, tem visitas na escola também.

Entrevistadora: Nos momentos de estudo?

CPSB: A não ser quando a gente pede a parceria deles, aí tem. Tem uma outra formação que eu esqueci de comentar que é através dos profissionais que fazem parte do centro-escola, que atende as crianças que tem dificuldades de aprendizagem encaminhadas pela escola. Então, quando a gente solicita, eles vêm até a escola.

Entrevistadora: São especialistas?

CPSB: Tem fono, TO, psicopedagogo.

Entrevistadora: E eles formam o professor na escola?

CPSB: Quando a gente solicita, eles vão até a escola e dão umas orientações também. Tanto da área acadêmica quanto da área da necessidade especial de cada criança.

Entrevistadora: Eu queria que você falasse um pouquinho mais de que forma o professor articula essa formação com a sala de aula. Tanto a formação que vocês desenvolvem no momento de estudo, no HEC, quanto a essa que a secretaria proporciona em relação a essa parceria com a universidade e outros estudos. Como tudo isso se articula com a sala de aula?

CPSB: O que a gente percebe é que a maioria dos professores que se disponibilizam a fazer esses cursos, eles procuram levar para a prática sim de sala de aula e dar um retorno pra gente, se ta dando certo, se não está. Então esse espaço do HEC também é pra isso. Eles vem até o curso ou na secretaria ou em qualquer outro espaço, fazem o curso. Há essa socialização e há esse tempo pra aplicar na sala de aula. Aí, eles dão a devolutiva pra gente. Se algo está funcionando, se ainda não, se eles precisam melhorar. Mas a maioria, não digo $100 \%$, a maioria, eles procuram sim aplicar na prática.

Entrevistadora: Eles procuram aplicar por uma iniciativa deles?

CPSB: Isso. Como eu te falei. Quando eles incorporam aquilo como necessário, eu percebo muito isso. Por que tudo que imposto, a gente percebe que não está fazendo porque gostou, ou por que acredita e sim por que é imposto. Então quando eles vão, eles vão por que eles querem aprender. Ninguém obriga a fazer o curso.

Entrevistadora: Quando há essa articulação do que ele estudou com a prática, é por iniciativa dele? Isso não está na proposta do curso? Vamos dizer assim, há um desdobramento de aplicação prática?

CPSB: Não. Alguns cursos não. Não digo todos, mas alguns não. Os cursos são mais teóricos e aí não tem aquela cobrança. Muitas vezes é mais uma questão teórica mesmo e reflexiva e o professor tem que se apropriar daquilo e adequar a sua realidade. 
Entrevistadora: Você acha que o PNAIC tem uma proposta assim? De aplicação?

CPSB: Tem, ele tem.

Entrevistadora: Os professores realizam?

CPSB: Sim. Realizam e estão satisfeitos. Isso sim eu percebo pela minha escola, que elas estão bem motivadas. Nos outros cursos você não percebe essa articulação como é percebida no pacto. Os outros cursos não são em grande escala como no pacto. Então não dá pra ter essa noção, mas eu percebo assim, que o professor, quando ele se disponibiliza a fazer, ele procura sim. Por que se ele ta procurando uma formação, é porque ele não está satisfeito com algo, com alguma coisa, alguma prática, alguma estratégia que ele esteja usando. Então eu percebo assim, quando ele se disponibiliza a ir, ele ta em busca de alguma coisa. Ou em busca de melhorar ou em busca de realizar alguma prática.

Entrevistadora: E os professores e as escolas avaliam a proposta de formação da secretaria de que forma? Como vocês fazem essa avaliação?

CPSB: Muito positiva. Acho que toda formação em termos de rede, ela ta de um tempo pra cá contribuindo muito com a formação dos professores. Ela possibilita não só a questão da parte teórica, mas a reflexiva. Por que não adianta só teoria, teoria, teoria e não refletir sobre a minha prática e tentar transpor. Então nesse ponto a teoria tem contribuído muito.

Entrevistadora: Existe um processo de avaliação, onde vocês avaliam formalmente essa proposta?

CPSB: Nos próprios cursos, nos finais, eles pedem pra fazer uma avaliação. Em termos de escola, a gente não faz. O próprio curso mesmo. Então cada professor que participa como integrante, ele mesmo avalia. Mas aqui eu não tenho acesso às avaliações. Só quem faz o curso.

Entrevistadora: Obrigada. Você quer falar mais alguma coisa sobre a formação?

CPSB: Eu acho que é isso. Eu Acho que o mais importante de tudo isso é o educador ele ter a vontade de buscar quando ele tem a vontade e tem os recursos em mãos, que é o que está acontecendo. "Enes" cursos oferecidos aí. Ele tem essa disponibilidade, eu acho que é o caminho.

Entrevistadora: Obrigada. 


\section{SISTEMA C}

\section{Gestor Municipal do Sistema C - GMSC}

Entrevistadora: O município realiza formação de professores?

GMSC: $\operatorname{Sim}$

Entrevistadora: De que forma, como é que vocês realizam esta formação? Qual é o formato da formação de professores de vocês?

GMSC: Nós temos 10 escolas de ensino fundamental, 10 Emefs e todo inicio de ano tem um planejamento, que é o planejamento anual. E nesse planejamento são colocadas as expectativas dos professores em relação ao ano, tanto em relação a sala de aula quanto a formação. Desenvolvimento de projetos em sala de aula e quais formações externas poderiam contribuir. Então diante disso é feito um levantamento, um estudo da possibilidade dessa formação e aplicação dela durante o ano. Então nós já participamos aqui de algumas ações do governo federal, alguns projetos do governo federal, no caso, o pró-letramento, o letra e vida e agora, atualmente a gente está com o pacto nacional pela alfabetização, além de outros cursos que também percebemos a necessidade de acordo com as expectativas do grupo, do nosso grupo de professores. Então já houve formações direcionadas em relação a produção textual, direcionadas a professores de $4^{\circ}$ e $5^{\circ}$ anos, até pra saber melhor como lidar com essas avaliações externas, SARESP, Prova Brasil. Atualmente, no nosso município estamos com a formação do Pacto, atendendo professores de $1^{\circ}, 2^{\circ}$ e $3^{\circ}$ anos. São dois formadores, eu trabalho com $1^{\circ}$ e $2^{\circ}$ ano e professora que trabalha com professores de $2^{\circ}$ ano, alfabetização e linguagem.

Entrevistadora: Então nesse ano vocês estão só com o Pacto?

GMSC: Esse ano só com o Pacto. Atualmente só com o pacto.

Entrevistadora: Vocês têm alguma formação voltada especificamente para a Educação Infantil, pra creche?

GMSC: Não, as formações que acontecem na educação Infantil são as formações de rotina que acontecem diariamente que são os estudos em HTPC. Mas são formações assim, que estão dentro da jornada de trabalho delas e são os horários de trabalho pedagógico que elas têm na unidade, então elas tem formação continuada com a presença de coordenadora da unidade.

Então todos os estudos direcionados a essa turma, a esses professores de educação infantil, são sugestões da coordenadora geral do município, no caso, a professora, que passa sugestões de leitura, de aprofundamento nas unidades. Agora formação em âmbito Geral, nós estamos com o Pacto. Atualmente somente com o pacto.

Entrevistadora: Então quer dizer que existe aqui na Secretaria alguém que direciona um pouco esse HTPC, esse momento na escola.

GMSC: Sim, tem. A coordenadora geral, a coordenadora pedagógica geral que direciona todo esse trabalho de estudo da educação infantil e do ensino fundamental. Então essa coordenadora, ela faz um estudo mais aprofundado das necessidades dos professores nas unidades, elabora o material em discussão com mais coordenadoras locais, pra tirar um material único pra ser estudado nas unidades, no horário de trabalho pedagógico. 
Entrevistadora: De certa forma ela coleta essas necessidades da escola ela combina meio que isso com as coordenadoras?

GMSC: Isso, até a coleta é mais feita pela coordenadora local, como cada unidade tem uma coordenadora, ela vê as necessidades da unidade, do grupo de professores e em pauta com a discussão com as outras e com a coordenadora local, elas chegam no consenso, qual o assunto pra ser abordado e direcionado nos HTPCs.

Entrevistadora: Certo.Você falou sobre as avaliações externas?

GMSC: Sim

Entrevistadora: Que vocês têm alguma coisa voltada pra isso? Como é isso?

GMSC: Não é que é bem voltada. Como nós todos os anos nós participamos dessas avaliações externas, alguns HTPCs são direcionados pra reflexão do que são essas avaliações, então porque elas acontecem, até pra conscientizar o professor da importância dessas avaliações. Dessas avaliações que vêm. Então, nos próprios HTPCs são feitas leituras de manuais didáticos, de aplicação de provas, até pra conduzir melhor o professor no momento da aplicação. Não algo bem direcionado às questões em si, mas assim âmbito maior, como porque que existem essas avaliações, pra conscientizar mesmo os nossos professores dessa necessidade de esta aplicando essas avaliações externas.

Entrevistadora: Agora eu gostaria de te perguntar o seguinte: durante o andamento dessas formações, tanto no HTPC, como das formações do PNAIC, como essas que você disse. Como é participação do professor?

GMSC: Como assim a participação? Nos encontros, a questão da adesão?

Entrevistadora: É a adesão, mas também, assim: qual a articulação disso, de que forma essa formação que vocês organizam chega às escolas, mesmo essa que a coordenadora organiza, como é a participação do professor, de que forma ele participa dela?

GMSC: No caso, essa formação na unidade local, na unidade local que é a unidade de trabalho dos professores, todos têm que participar porque está dentro do horário de trabalho semanal, então como faz parte da rotina semanal, eles participam. Essas formações externas que nós fornecemos, que nós favorecemos através do governo federal, ou até da necessidade, como é em horário fora do horário de trabalho é uma adesão. Então é feita uma conscientização da necessidade, e nós temos assim, um professorado muito preocupado, não sei se é um privilégio aqui nosso, mas os nossos professores, todas as formações que nós passamos, direcionado a $1^{\circ}, 2^{\circ}, 3^{\circ}, 4^{\circ}$ e $5^{\circ}$ ano, a adesão é muito grande. Claro que a gente não consegue atingir os $100 \%$, mas estamos beirando lá. E, e nós percebemos assim, tem sempre alguns professores que se destacam mais nessas participações, tanto de relato de experiência, quanto em participações Tem um grupinho assim que a gente percebe que são pesquisadores natos. Eles buscam muitas coisas fora, que acaba acrescentando nessas formações. Então além de ter o formador preparado pra isso, a gente tem um grupo de professores por fora que são os alunos do curso que contribuem muito com essas pesquisas externas que eles acabam fazendo. Mas é uma busca individual, porque eles vêem a necessidade disso.

Entrevistadora: Como é que vocês vêem a questão da sala aula, o trabalho da própria sala de aula, daquilo que o professor desenvolve como prática. Como isso aparece na formação? Como vocês enfocam isso? 
GMSC: Olha. Depende muito da estrutura da formação que a gente monta. Porque, eu vou citar uma formação que foi realizada aqui, se não me engano, há uns dois anos sobre produção de textos. Percebeu-se a necessidade, foi uma época que houve muita contratação de professores que chegaram, muitas vezes não atuantes, saíram de faculdades ou nunca tinham assumido uma sala de aula e nós vimos a necessidade de aplicar uma oficina de formação pra esses professores de $4^{\circ}$ e $5^{\circ}$ anos, direcionada a produção textual. E nessa estrutura de cursos nós colocamos um dos tópicos relatos de experiências de professores que já estão com a gente há algum tempo. Então foi muito produtivo porque houve professores que não estavam fazendo o curso, porque não eram de $4^{\circ}$ e $5^{\circ}$ ano, mas já tinham trabalhado com $4^{\circ}$ e $5^{\circ}$ ano e vieram colocar os relatos de como eles produziam, de como eles trabalhavam essa temática, produção textual. Então todos os cursos que nós elaboramos, que nós montamos aqui pela secretaria, a gente sempre reserva um tempo pra relato de experiência. Pra que essa experiência colocada em sala de aula, seja mais um, digamos assim, um conteúdo a ser trabalhado nas nossas formações. Até pra comprovar, tudo que é feito na teoria, tudo que é falado na teoria pode ser aplicado na prática. De que maneira. A gente percebe muito isso através do relato dos professores. Então toda a formação, é o que eu digo pra você, ale, da análise teórica, da leitura de textos, nós temos o momento do relato de experiências. Isso contribui muito com a gente, inclusive o PNAIC, o Pacto, a estrutura do Pacto sugere muito isso, a discussão, é, colocar em pauta toda a prática, toda a vivência delas, deles, realizadas em sala, então, assim, o que eu percebo, como formador do pacto agora, é que muito do que a gente está lendo, estudando na teoria é o que muitas já aplicam na prática. Isso a gente percebe visivelmente, pelo relato, pela visita que a gente faz na sala de aula, até pra comprovar tudo que é falado, a gente vai até pra aprender um pouco mais. E tudo isso fica bem em evidência mesmo.

Entrevistadora: O município, a própria secretaria, ele tem um plano de formação sistematizado ou ele realiza sua formação conforme a necessidade. Como é que vocês organizam isso, como é que vocês pensam isso. Você disse já que vocês chamam as pessoas, mas isso está sistematizado, documentado, tem alguma coisa assim?

GMSC: Então, é mais pela segunda fala sua, a gente mais sente a necessidade do grupo, só que acaba sendo algo sistemático, porque todo início de ano, no planejamento inicial a gente tem na nossa programação, na nossa pauta de planejamento essa questão de dar liberdade pro profissional colocar em questão o que ele acha pertinente na sua formação profissional e pedagógica. Então em todo início de ano é feito esse levantamento e a partir daí que a gente começa a buscar formações pra ocorrerem durante o ano letivo. Então como eu disse, nós vimos a necessidade dessa produção textual pro $4^{\circ}$ e $5^{\circ}$ ano, que até $1^{\circ}, 2^{\circ}$ e $3^{\circ}$ ano, a coisa estava caminhando, mas quando chegava no $4^{\mathrm{a}}$ e $5^{\circ}$ ano, que entram várias questões de estruturação, os nossos professores iniciantes, e alguns já atuantes há algum tempo estavam apresentando muita dificuldade de como lidar com isso, mas isso assim, foi em decorrência do ano, tanto que essa formação ela não foi prevista no início, foi algo que nós percebemos a dificuldade durante o ano letivo. Não tinha sido prevista no planejamento de fevereiro, mas a gente incorporou porque viu a necessidade.

Entrevistadora: Vocês estão com a troca de governo aqui? GMSC: Sim

Entrevistadora: E você percebeu se isso algo sistematizado já de anos atrás ou essa é uma prática atual? 
GMSC: Não, ela já vem de alguns anos e permanece nessa nova gestão. Eu já estou na rede há treze anos e eu posso falar que, não muito ao certo, mas que já há uns cinco anos essa prática já é efetiva aqui no nosso município.

Entrevistadora: Existe aqui na secretaria um grupo que organizaria essa formação. Não é isso?

GMSC: $\operatorname{Sim}$

Entrevistadora: Como é essa estrutura da secretaria?

GMSC: Nós temos aqui, as duas supervisões, a do infantil e a do fundamental, a coordenadora pedagógica municipal, o diretor do fundamental e o diretor do infantil, que sou eu. Então quando a gente programa, quando nós programamos uma formação, sentamos toda a equipe pra elaborar toda essa estruturação e procurar, talvez, algum profissional mais habilitado pra lidar com aquele assunto e a gente valoriza muito o profissional de sala também. Pra ele falar, pra ele debater, pra ele colocar relato, pra ele inserir um assunto novo, pra ele discutir outros assuntos. Então quando a gente não encontra, a gente procura profissionais de fora pra estar acrescentando na formação. Agora nós temos um grupo muito bom aqui que dá pra gente aproveitar nessas formações. Como tutores mesmo.

Entrevistadora: Certo, e como que vocês organizam, são palestras, oficinas, quando vocês organizam?

GMSC: São mais oficinas do que palestras, porque isso é até um pedido delas. No planejamento de início de ano, quando elas colocam as questões das formações elas pedem muitas oficinas práticas, porque é o que elas encontram, é o que vem ao encontro das necessidades de sala de aula. Então nós trazemos formação todo ano. Nós temos a nossa semana de expressão cultural, nós temos a nossa semana do bebê, que a gente traz formações, palestras de fora, de pessoas renomadas no assunto, mas sempre a cobrança delas é que sejam oficinas, pra prática mesmo, pra aprendizagem prática. E esse ano, até ilustrando a situação, na nossa semana do bebê, que uma semana direcionada à primeiríssima infância, é uma semana de muita formação nas creches, nas nossas creches. Então nós trouxemos alguns palestrantes, as próprias unidades buscam palestrantes na nossa cidade, pessoas que trabalham no SOS pra ter uma fala, policiais militares, assistentes sociais, é uma fala de formação não tanto pro nosso profissional, mas mais pra sociedade, o público. Porque a gente pensa muito também nessa parceria da família, com a comunidade. Então a semana do bebê é uma semana que ilustra bastante a nossa busca constante pela formação. Não só do profissional, da instituição, mas da sociedade, da comunidade, do entorno como um todo.

Entrevistadora: Quando vocês coletam essas necessidades das próprias escolas, dos coordenadores é uma forma de fazer um diagnóstico das necessidades, do direcionamento da formação. Há um outro tipo, uma outra forma em que vocês diagnosticam a necessidade da rede?

GMSC: Assim, basicamente é essa. Na elaboração do PP, no início do ano, junto com o planejamento tem a equipe de profissionais responsáveis pela elaboração do PP, e nessa equipe de profissionais, você deve saber bem, tem a comunidade que representa. E essa comunidade são pais atuantes. A gente sabe que são pais que atuam, que veem a comunidade muitas vezes com olhos que a gente lá, profissional da unidade, a gente não vê. Então, eles participam, eles colocam também muitas questões que contribuem pra gente pensar nas formações dos nossos professores. Então nós temos unidades aqui, por 
exemplo, que são mais periféricas, então muitas vezes a formação direcionada pra esse profissional dessa unidade é diferente de uma formação direcionada a uma unidade mais centralizada, onde os objetivos e os anseios da comunidade e até do profissional daquela unidade é outro. Existem as formações gerais, mas também existem aquelas formações focadas nas necessidades da realidade da comunidade em si. Então os pais atuam muito na hora do PP, na hora de citar, na hora de argumentar, até de questionar eles colocam muito essas necessidades, que é onde gera as nossas formações, ajuda a contribuir com as nossas formações.

Entrevistadora: E isso vem tudo pra cá ( para a secretaria)?

GMSC: Vem tudo pra cá. Que onde é tudo condensado na sala da supervisão com a coordenadora pedagógica geral que é filtrado. Porque nem tudo dá pra gente aplicar durante o ano, então a gente filtra aquelas necessidades mais urgentes pra serem realizadas durante o decorrer do ano letivo.

Entrevistadora: Essas pessoas que trabalham nessa equipe teriam função pedagógica e administrativa?

GMSC: São divisões. No caso as supervisões tem as duas partes. Falando aqui, na secretaria. Tanto a supervisão do fundamental, quanto do infantil, tem a parte burocrática, mas eles caminham junto com a pedagógica. A minha parte, enquanto diretor do departamento de educação infantil é burocrática. É extremamente burocrática. Só que eu não deixo de me envolver $\mathrm{cm}$ o pedagógico, que como eu já faço parte da formação eu tenho que me envolver. Então a todo o momento eu estou na sala da supervisão, conversando com a supervisora do infantil pra discutir questões pedagógicas, questões de necessidades, de formação, então a gente acaba se envolvendo. O diretor é a mesma situação. Ele também. A parte dele é mais burocrática, mas ele também acaba se envolvendo com o pedagógico. Agora especificamente pedagógico, é uma coordenadora geral. Que ela só trata das questões pedagógicas de todo o sistema. Educação infantil, fundamental e o EJA, que nós temos também.

Entrevistadora: A gente falou bastante do planejamento. Vocês têm alguma forma específica, algo que você poderia dizer sobre o acompanhamento durante a formação, a forma como vocês avaliam isso, os resultados?

GMSC: Ah, sim. Nem toda formação há. As que a gente percebe a necessidade é feita uma tabulação de dados mo final da formação. No início, como se fosse uma diagnóstica dos anseios e, no final, se esses anseios foram alcançados. Então há sim essa tabulação. Voltando à semana do bebê, nós oferecemos, nesse ano, quatro oficinas pras educadoras que trabalham com crianças de zero a três anos. Oficinas que elas levantaram a necessidade no início do ano, no planejamento. Então nós oferecemos essas oficinas e fizemos uma tabulação de dados no início da formação e no final. As expectativas e anseios de todo o grupo e a conclusão disso, se isso foi alcançado ou não. E nós tivemos uma surpresa, assim, maravilhosa, que nós atingimos assim, $100 \%$ de pontos positivos. Não houve nenhum ponto negativo nessas quatro formações. Porque eram formações que elas já cobravam há anos e nunca foi possível. Esse ano a gente conseguiu buscar os formadores, alguns da cidade, outros de fora pra trabalhar essas quatro oficinas.

Entrevistadora: Você sabe que temas são esses que foram tratados?

GMSC: Eu sei. Se eu não me lembrar, eu tenho que buscar no meu caderno, mas foram oficina de bonecas, massagem para bebês, que elas trabalham muito com o B1, questão 
de massagem, atuação dessas massagens com os pais, brinquedos em tecido e artes plásticas. Então tudo prático, que elas trabalham diariamente, então elas têm que adequar tudo isso na rotina semanal que elas têm. Elas preparam e é sempre é uma cobrança delas porque como é algo prático, não dá pra buscar só em manuais de leitura, tem que ter a formação concreta. Então é algo que elas pediam há algum tempo e havia formações só que muito teóricas e esse ano a gente privou pela prática

Entrevistadora: Essa formação foi dada por quem?

GMSC: Houve profissionais da saúde, da educação, da assistência social, que são profissionais que já trabalham com isso no ambiente de trabalho deles, então eles vieram trocar essas experiências com a gente.

Entrevistadora: E essa específica de artes plásticas, como é que foi?

GMSC: Ela trabalhou muito com sucata, com construção de objetos através de sucata, usando mais o papel. Prato de papelão, copo de papelão, a própria caixa de papelão, através do que eu posso construir com essas caixas, porque isso é um material que as crianças quando a gente pede, eles trazem. E muitas vezes a gente não sabe o que fazer. Sabe que pode fazer algo, mas a gente não tem a formação técnica pra isso. Então esse trabalho foi muito bom, como eu coloquei pra você, a produtividade foi $100 \%$.

Entrevistadora: Em relação aos cursos do governo federal, vocês interferem de alguma forma? Como é que o curso, por exemplo, o PNAIC ou outros cursos, como é que ele entra no município, como ele se articula com o trabalho do professor, como é que a secretaria interfere ou não no desenvolvimento desses cursos?

GMSC: Então. Quando vem um curso do governo federal, ele já vem praticamente com a estrutura pronta. É só de aplicação, então corresponde a cada município aplicar esse curso. Eu já fiz o "Letra e Vida". Não como tutor, mas como aluno e depois participei do pró-letramento, não sei se você ficou sabendo na época, de alfabetização e linguagem. Nós fizemos formações fora, pela Unicamp, algumas formações pra aplicar aqui. O pró-letramento, falando mais especificamente dele, ele veio com uma estrutura, mas ela podia ser adequada à realidade do município. Então essa questão tem coisas que não tem como adequar, como a questão das horas, elas tem que ser cumpridas, mas a questão da dinâmica de trabalho, o tutor do curso, claro, juntamente com a permissão da coordenadora pedagógica da secretaria, pode fazer algumas alterações no andamento co curso. No pró-letramento houve essas alterações e no PNAIC também está havendo. Assim, eu estou indo nessas formações e estou percebendo que alguns assuntos do material, pra nossa realidade aqui, não é tão pertinente quanto outros. Então como o material é muito extenso, e as horas do curso não são possíveis pra realizar tudo isso, eu, juntamente com a coordenadora pedagógica, a gente senta e a gente seleciona, do material, o que é mais pertinente pra gente. Tem muita coisa lá, como eu disse, que nós já fazemos, já é uma rotina, já é uma prática. Então é algo que já está consolidado. A gente está pegando o que é novidade pra trazer pro grupo, até pra dar mais tempo pra gerar aquela troca de experiências, aplicação disso em sala de aula e trazer o retorno pra gente, de como foi. Porque a gente valoriza bastante essa parte da experiência em sala de aula.

Entrevistadora: Nos cursos desenvolvidos por vocês, de uma maneira geral, existe alguma produção do professor? Ela traz alguma produção, após ou durante esses cursos. Produção pessoal dele a respeito disso? 
GMSC: Sim, sim, eles trazem. Só que não é uma produção final. Durante todos os encontros, falando do pró-letramento, eles sugerem ações, atividades práticas mesmo. Pra serem realizadas em sala e trazer uma resposta daquilo. Então eles sempre aplicam atividade e trazem as respostas pra gente. No caso do PNAIC, já pedia um produto final, como se fosse um projeto, uma sequência do projeto. Você participa de todo o curso e no final você apresenta um produto sobre tudo aquilo que você aprendeu. Então no PNAIC, no caso, eles estão realizando sequências didáticas. Tem uma unidade do PNAIC que trata sobre projeto, de sequências. Em grupo, eles estão realizando uma sequência didática de atividades. Essa sequência didática está sendo aplicada em sala, e no final do curso vai ser exposto para os outros cursistas, pros outros professores. A sequência trabalhada, vai ser encadernado esse material, inclusive vai ser levado em Assis, pro seminário que vai ser realizado lá com a gente. Então, falando em estrutura, o Pró-letramento, essa reposta, esse material que vai ser levado pra sala foi durante todo o decorrer. No PNAIC, houve também, mas teve mais esse acréscimo do projeto final. Eles estão realizando o projeto final, que é um projeto. Além de teórico, eles buscam materiais, eles buscam fontes teóricas que defendem aquele tipo de atividade. Ele é prático também porque é aplicado em sala de aula.

Entrevistadora: Certo. Com exceção desses, vocês tem alguma outra produção, em outras formações?

GMSC: Não, que eu me lembre, no de produção de textos que nós fizemos, já foi mais direcionado à parte teórica mesmo. Claro que nós analisamos prática, mas não foi nada aplicado em sala de aula. Porque não foi uma formação tão extensa. Essa formação, se não me engano, foram 32 horas. Então nós focamos mais o debate em sala de aula e discussão de práticas de vários professores, não só deles. Então eles não tinham que aplicar, no momento da formação, o que a gente estava discutindo. Houve formações também na educação infantil, inclusive o Secretário trabalhou com elas diretamente ele poderia falar melhor - a questão das ciências aplicada na educação infantil, toda a parte prática das ciências. Como pode ser aplicada nas etapas 1 e 2 do pré, houve essa formação também que foi um pedido das professoras. Elas queriam trabalhar mais essa parte de aprendizagem lúdica e concreta, então foi um pedido e foi realizado. $O$ tutor foi o Secretário de Educação, que é formado em biologia.

Entrevistadora: Com relação ao currículo do $1^{\circ}$ ao $5^{\circ}$ do fundamental. Vocês têm um currículo unificado?

GMSC: É, nós temos assim, as disciplinas do núcleo comum que fazem parte do planejamento de cada um, mas cada unidade elabora o seu. Cada unidade tem o seu PP, tem o seu planejamento anual, tem o seu planejamento particular de aulas. Então cada $1^{\circ}$ ano vai ter o seu planejamento. A gente segue um material único, que é o livro didático. No final do ano passado, nós fizemos uma reunião com todos os professores, discutimos todos os materiais didáticos, todos os livros e optamos por pedir o mesmo, pra trabalhar toda a rede com o mesmo livro de $1^{\circ}$ ano, de $2^{\circ}$, até pra evitar aqueles transtornos de transferência, quando o aluno se transfere, não tem o livro, então ele fica sem o livro. Então nós optamos por fazer isso, mas mesmo assim, cada professor elaborou o seu. Então os conteúdos são os mesmos, mas a prática, a maneira que você vai intervir e mediar, cada professor tem a sua prática.

Entrevistadora: Mas não há, por exemplo, um direcionamento da própria secretaria quanto aos conteúdos? 
GMSC: Nós temos as diretrizes, que nós seguimos, da Secretaria. Existe. Ela pauta os conteúdos a serem trabalhados. Então esses conteúdos são adequados com o material didático que vem do governo federal, até então, e adequado com a metodologia de cada professor. Mas há essa diretriz da secretaria municipal. De zero até o $5^{\circ}$ ano do ensino fundamental.

Entrevistadora: Existe alguma formação pra gestores? Como os gestores participam? GMSC: Já houve eu não posso falar bem ao certo porque na época eu estava em sala de aula como professor. Houve sim várias formações pra gestores, diretor e coordenador de escola, mas não aqui. Se não me engano foi em Presidente Prudente. Agora, a temática, não sei te falar ao certo qual foi. Mas foi no âmbito de gestão mesmo.

Entrevistadora: E os gestores participam das formações que vocês realizam?

GMSC: As do governo, quando vem essas formações de fora, eles delimitam a quantidade e o profissional envolvido. Então elas acabam excluindo os gestores, porque atendem professores que estão em sala de aula, no caso o PNAIC e o pró-letramento. Agora as formações que nós fazemos por nós mesmos, de acordo com a necessidade, o coordenador tem que se fazer presente. Por que é ele que vai acompanhar toda a aplicação na escola.

Entrevistadora: E o diretor?

GMSC: O diretor não, a não ser que ele queira. O coordenador, sim, porque é o coordenador que vai ter o papel de passar pro gestor, passar pros outros profissionais da unidade o que está fazendo. E acompanhar o trabalho daquele que fez o curso.

Entrevistadora: OK. Acho que é isso.

GMSC: É isso?

Entrevistadora: Obrigada.

\section{Gestor Escolar do Sistema C - GESC}

Entrevistadora: Os professores da sua escola participam da formação do município?

GESC: Olha, 90\% participa. Alguns professores, inclusive a gente tem professores aposentados aqui, que já não pensam mais em fazer. E a gente vê diferença na prática dessas professoras que fazem a formação e daquelas que acham que já sabem tudo e não precisa mais de formação.

Entrevistadora: Você acha que tem uma diferença na prática desse professor? Como é que vocês percebem isso?

GESC: É bem claro. As professoras que fazem formação estão sempre inovando, sempre mudando a forma de lidar com os conteúdos. Enquanto essas que já se acham formadas, o que elas já sabem tem anos de carreira já não precisa. Até hoje deu certo, então agora é que vai mudar. Essas professoras continuam da forma tradicional, massacrando aquelas crianças, sempre das mesmas formas que a gente via há anos atrás. É evidente a diferença. 
Entrevistadora: Como é que você percebe a formação do município. Como é que ela chega até a escola?

GESC: Olha, a gente participa com reunião de coordenador, de diretor lá embaixo ( na secretaria), que eles sugerem cursos pra gente, principalmente pra coordenação que participa mais ativamente ali junto com os professores em HTPC. A gente recebe, como é que eu posso dizer - as coordenadas de como vai ser, as sugestões do que a gente acha que seria necessário pros professores, pra eles articularem um curso bacana e diante dessa pesquisa eles buscam pra gente. Então, junta-se, a gente passa pro professor e muitas vezes a coordenadora mesmo diante da realidade nossa, elas procuram textos pra formar os professores diante da nossa...da dificuldade da nossa escola também.

Entrevistadora: Você acha que a formação é mais realizada pelo que a própria escola desenvolve, pensa com autonomia ou você analisa que há um direcionamento grande da secretaria pra essa formação. Como você avalia isso?

GESC: Não, eu acredito que a secretaria num todo, vê as dificuldades de todas as escolas e procura um curso que atenda à demanda de todos, mas nós temos autonomia de ver a nossa dificuldade e buscar entre nós e a gente estuda em HTPC, através da coordenação.

Entrevistadora: Como é que vocês organizam esse estudo?

GESC: A gente senta com os professores em HTPC, levanta as dificuldades de algum aluno, passa pra equipe. Tem professores que buscam também pra contribuir com a coordenação. Ela busca informações, busca os textos e elas estudam em HTPC, que é num horário depois da aula.

Entrevistadora: Principalmente estudos de textos?

GESC: Estudos de texto, análise de atividades.

Entrevistadora: Quanto aos temas que vocês desenvolvem na formação do município. Como as escolas participam do planejamento?

GESC: A gente tem reuniões periódicas, principalmente reunião de coordenação. Aí elas levantam a dificuldade que a maioria das escolas passa, passa pra coordenadora geral e a coordenadora geral busca junto com o pessoal lá, os chefes, um curso que consiga abranger todas as dificuldades.

Entrevistadora: Que tipo de curso vocês tem desenvolvido aqui?

GESC: Esse ano os professores estão participando daquele curso do Pacto da alfabetização. Tem vários professores aqui da escola que estão participando. Do ensino fundamental até agora que eu me lembre, é só esse.

Entrevistadora: E nos outros anos, que tipos de cursos vocês tinham aqui? Como é que eram os cursos?

GESC: Olha, deixa eu lembrar...Cursos, a gente já fez vários cursos, já teve cursos de gestão pra gente, teve curso de pró-letramento, letra e vida, que são oferecidos pra quem tem interesse, não é obrigatório. As pessoas conscientes vão em busca mesmo, tanto é que às vezes não tem vaga pra todos, a gente tenta organizar até nesse curso que está tendo agora, teve coordenadores que queriam participar, mas o número de vagas não foi suficiente. A gente corre atrás, os professores correm atrás e quando não dá vaga pra todo mundo, esses professores que estão fazendo, eles vem e disseminam ali no HTPC 
pros professores mesmo. Eles socializam com todos pra que todos tenham oportunidade de ver o que ta sendo trabalhado e aplicar todos na mesma escola.

Entrevistadora: Existe algum documento da secretaria de educação, como um cronograma de cursos durante o ano, um planejamento mais sistematizado daquilo que vai ocorrer em termos de formação?

GESC: Não. No início do ano a gente participa de planejamento junto com os professores e eles sugerem cursos, sugerem temas que durante o ano vão ser desenvolvidos. Então eles buscam pra ser desenvolvido.

Entrevistadora: Vocês também fazem cursos voltados pras avaliações externas? GESC: Sim.

Entrevistadora: Como é que vocês trabalham isso?

GESC: Olha, a gente está trabalhando o SARESP agora, junto com a diretoria de ensino, nós tivemos reuniões na diretoria de ensino, tivemos reuniões na prefeitura e diante do que eles passam pra gente, a gente desenvolve aqui na escola. É bem informativo e alivia um pouco a tensão, porque a gente fica tensa com essas avaliações. Tira e esclarece bem as dúvidas. Dá um direcionamento bem bacana pra deixar a gente bem tranquila.

Entrevistadora: Essas formações em relação às avaliações externas vem através de documentos da secretaria?

GESC: Isso. Vem através da coordenadora geral ela passa pra gente, o diretor de departamento passa pra gente.

Entrevistadora: Que tipo de documento que é esse?

GESC: É ele passa por e-mail, passa por CI, por telefone.

Entrevistadora: Mas o que é o documento? Qual o seu teor?

GESC: Colocamos as dúvidas, a gente teve uma reunião na semana passada. Elas colocaram as dúvidas, aí elas descrevem e mandam por e-mail pra todas as escolas, esclarecendo as dúvidas, ou por telefone, a gente liga também pra esclarecer.

Entrevistadora: Sobre o trabalho do professor em sala de aula. Como você diria que esse trabalho, o que ele faz no dia-a-dia dele, de que forma ele está articulado com a formação que vocês fazem de uma forma geral?

GESC: Olha, a gente busca assim, a dificuldade casar com a aprendizagem teórica e a prática. Muitos professores buscam a dificuldade através dos cursos. A coordenação está sempre voltada pra tentar solucionar. Ela também participa de cursos, ela busca interferir junto na sala, intervir junto com o professor pra tentar ajudar o professor na sala pra tirar aquela dificuldade.

Entrevistadora: E isso aparece de alguma forma nos cursos? O curso que ele fez, a palestra, a oficina, ele desenvolve isso na prática?

GESC: A maioria dos professores trazem pra prática. A gente vê na sala de aula atividades, uma troca. EStá sendo muito bacana esse curso do pacto. A troca entre os professores daqui, que elas falam: "olha essa atividades que nós aprendemos. Vamos aplicar?" E as duas do mesmo ano aplicam, vêem a diferença. Falam, "Olha, nesse ponto..."Então a troca entre elas, que participam do curso, sai na sala, é evidente a 
atividade, aí uma compara com a outra. "Olha, o meu aluno está nessa fase...o meu, já teve mais dificuldades" Então entre alas, o curso é tão bom pra elas que até elas trocam, mesmo não sendo em HTPC. Em horário de café, no horário em que chega aqui. Elas estão sempre trocando o que estão aprendendo nos cursos.

Entrevistadora: E nos HTPCs há um espaço pra essas trocas de experiências, pro planejamento de atividades?

GESC: Sim. Uma vez na semana que é específico pra troca de experiências que elas trocam entre elas atividades. Um dia na semana.

Entrevistadora: E os diretores, eles tem alguma formação específica, voltada pro diretor. De que forma o diretor da formação?

GESC: Na formação com os professores?

Entrevistadora: É de uma forma geral?

GESC: Esse ano, eu fiz uma formação fora da rede. Eu fiz pós-graduação fora, diante da realidade que a gente vê aqui. Mas o município ofereceu um curso agora de gestão. Só que a vaga como eu falei foi limitado, foi sorteio. Só que aí assim, quem faz, depois é marcada uma reunião pra gente socializar pra gente, pra gente não ficar totalmente fora.

Entrevistadora: Mas mesmo da formação dos professores, os diretores participam, tem uma abertura, como é isso?

GESC: Não. Quando tem vaga, sim. Mas a prefeitura dá preferência pra coordenação e professor que está mais atuante ali junto aos alunos. Os nossos cursos são mais direcionados. Quando a gente solicita e tem vaga é aberto pra gente também.

\section{Coordenadora Pedagógica do Sistema C - CPSC}

Entrevistadora: Nós vamos falar de três aspectos da formação: do planejamento, do acompanhamento e da formação. Como é a formação oferecida aos professores da rede? CPSC: Bom a gente tem as formações que são oferecidas pela secretaria, que seriam cursos e que podem ser feitos pelos professores. Nós temos formação continuada durante os HTPCs que são semanais. Os cursos, geralmente, ficam a critério do professor, se ele tem disponibilidade, se ele quer participar. Se ele quer fazer o curso, ou não. As HTPCs são obrigatórias para todos os professores.

Entrevistadora: Com relação aos temas, como é que eles são pensados, planejados?

CPSC: É assim: Nesse ano a gente está passando por uma mudança. Teve uma mudança na estrutura, no trabalho da secretaria. Então, Até o ano passado, nós tínhamos uma coordenadora pedagógica só do ensino fundamental. Então nós tínhamos reuniões semanais, quinzenais com ela e durante essas reuniões nós trazíamos as propostas de estudo, nós planejávamos o que seria trabalhado em HTPC, com as professores, de acordo com a demanda. Nós tivemos documentos do governo federal que nós tivemos que estudar, que são os currículos. Nós tivemos formações voltadas pra prática mesmo, 
tivemos oficinas pedagógicas, tivemos formações voltadas mais pra teoria, pra formação do professor em relação à teoria, aí varia, de acordo com o momento, de acordo com a demanda. Nesse momento nós estamos trabalhando avaliações externas. Estamos vendo quais as características, cada tipo de avaliação, os referenciais de conteúdo que ter em cada avaliação. Varia de acordo com o momento. Temos formações teóricas, voltadas pra teoria e temos formações voltadas pra prática, relacionadas à metodologia.

Entrevistadora: Você acha que elas podem ser divididas em formações mais teóricas e mais voltadas prá prática?

CPSC: É porque quando você estuda algum autor. Você estuda assim uma linha, uma proposta pedagógica baseada em alguma linha de pensamento em algum autor, fica mais na teoria. Agora quando você parte mesmo pra focar a metodologia, você vem com o como ensinar. Então você não fica preso em pensamentos de autores, no que seria o ideal. A gente parte pra prática mesmo. É o como ensinar, que tipo de objeto vou usar, que material eu vou usar, na utilização de um material concreto. Vamos supor um exemplo: do material concreto pra trabalhar matemática nas séries iniciais. Então assim, a gente vai trabalhar vários tipos... Eu passo pras professores, tipos de atividades que elas podem trabalhar. A gente reflete junto sobre o objetivo de cada uma. Vai de acordo com a demanda da escola, do contexto.

Entrevistadora: Se a gente pensar nas formações oferecidas pelo município você visualiza mais a questão teórica ou mais a questão prática. Como é que essa formação chega aqui na escola?

CPSC: Olha, quando a gente fala de cursos que são oferecidos. Por exemplo, até esse ano, em relação aos anos anteriores foi oferecido o curso Pró-letramento, o curso de língua portuguesa e de matemática, que são cursos externos oferecidos pelos professores, que fica a critério de cada um participar, de acordo com a disponibilidade que tem. São formações mais individuais, apesar de ser o grupo do município, a formação é individual, porque cada um absorve de um jeito, aprende de uma forma, mas falar assim se o que ela aprende vem prá prática?

Entrevistadora: E de que forma ela vem pra escola?

CPSC: Então, tem formações que são específicas pras coordenadoras. Que é pra nós passarmos para os professores. Então é feito primeiro uma formação com a gente e depois a gente vem e multiplica na escola com os professores. Então é uma maneira que chega. Agora assim, de cursos, é difícil, porque assim, a participação é de acordo com a disponibilidade, não tem um curso que é obrigatório pra todo mundo, entendeu? Que todo mundo tem que fazer. Então muitas vezes, a maioria dos professores não estão fazendo, é a minoria que está fazendo. Então, entre eles acontece a troca, mas vem pra prática, geralmente mais individual, sabe? Não vem assim pra escola toda, não.

Entrevistadora: Essa formação pra coordenadores que vocês recebem e repassam, como é?

CPSC: Depende, porque, por exemplo, no ano passado, a nossa coordenadora geral, que era a $(\mathrm{XX})$, e mais umas duas coordenadoras, elas foram pra um congresso, tipo um congresso em Águas de Lindóia, não me recordo se é essa a cidade. Lá eles tiverem 
várias oficinas, tiveram várias formações lá. O que eles fazem: no momento em que eles chegaram aqui, eles passaram pras coordenadoras o que eles aprenderam lá em termos de cursos que fizeram, fazendo muni-cursos, mini-oficinas. E elas se juntaram e elaboraram juntos, as pessoas que foram lá elaboraram juntas uma oficina pedagógica pra todas as professoras da rede. Então a gente conseguiu abranger todas as professoras da rede, porque foi feito em horário de trabalho. Essas oficinas foram feitas em horário de HTPC.

Entrevistadora: Você se lembra do tema?

CPSC: Eram jogos.

Entrevistadora: Matemáticos?

CPSC: Era... Era matemática. Voltado pra matemática. Tinha alfabetização?...Não, era mais jogos voltados pra matemática mesmo. Era. Aí foi específico assim, de primeiro e segundo ano, de terceiro e quarto.

Entrevistadora: Certo. E a que você mencionou para a coordenação?

CPSC: Isso. Da coordenação, vamos supor: eu vejo que um estudo recente que a gente fez agora foi sobre a avaliação do deficiente intelectual. Que critérios utilizar? Assim, é uma necessidade que a gente tinha. Era uma necessidade do momento, porque nós estávamos no conselho. Nós estávamos antes do conselho e a gente precisava saber que critério de avaliação que a gente ia utilizar pra saber se as crianças que apresentam deficiência intelectual. Então isso foi um problema, uma necessidade da rede toda. Então a $(\mathrm{XX})$, que é nossa coordenadora geral, selecionou um material pra ser estudado nas escolas. Então, num primeiro momento foi feita uma formação com as coordenadoras, onde todas nós analisamos o material, fizemos um estudo do material, discutimos e preparamos o que nós trabalharíamos em HTPC com as professoras. Então num segundo momento, trouxemos o material pras professoras, xerocamos os textos, algumas atividades práticas, assim, de reflexão, pra estar abordando o tema com as professoras. Pra que fosse assim: o nosso objetivo era refletir sobre avaliação, sobre os critérios de avaliação, consideradas as limitações e as dificuldades das crianças que apresentam deficiência.

Entrevistadora: Quando vocês trabalham a formação, o professor, de certa forma, traz isso pra prática? Vocês têm alguma forma de acompanhar se a formação recebida está se refletindo na prática?

CPSC: Eu como coordenadora acompanho. Tem professoras, não é um documento obrigatório, que fazem um diário, que é um documento que elas preparam as aulas delas. Então, pra acompanhar o que a professora está trabalhando em sala de aula, a gente vê esse diário, a gente olha os cadernos dos alunos, que não tem material melhor pra analisar o trabalho do professor do que o caderno do aluno. Então a gente pega o caderno dos alunos, a gente também olha o que o professor está trabalhando. Outra forma de acompanhar o trabalho do professor é, antes de passar as atividades pros alunos elas passam pra mim, por exemplo: a gente trabalha com atividades xerocadas, elas passam pra mim pra que eu veja as atividades, pra eu veja se as atividades estão dentro do contexto, pra saber se elas estão dentro da nossa proposta pedagógica, pra que sejam passadas pros alunos. E, assim, geralmente a gente acompanha o trabalho do professor de acordo com o rendimento da sala de aula. Você vê assim, o que está com mais dificuldade, o que está precisando de uma intervenção maior de acordo com o rendimento que a sala está apresentando. 
Entrevistadora: Como vocês fazem a avaliação da formação em geral? Vocês fazem algum tipo de avaliação? O professor participa? A escola participa avaliando a pertinência dos cursos, se foi bom, se não foi?

CPSC: Olha, geralmente, vamos supor: uma oficina pedagógica que é proposta pra rede toda, geralmente a gente faz uma avaliação, sim, no final. Depende, às vezes vem um documento escrito pro professor avaliar, às vezes a gente faz uma avaliação no grupo mesmo. Pontos negativos, pontos positivos. Sugestões pra melhorar em relação ao que foi proposto pra eles. Mas aí depende da situação.

Entrevistadora: E vocês participam da seleção dos temas ou do tipo de formação. Como é essa participação?

CPSC: Olha, esse ano nós estamos tendo uma autonomia maior pra trabalhar de acordo com a necessidade da escola, de acordo com a necessidade dos professores da escola. Até então, até o ano passado era unificado, o que era estudado nessa escola, seria estudado na outra escola, era a mesma coisa. Nesse ano, a proposta de trabalho da secretaria mudou em relação à coordenação pra que a escola tenha autonomia de identificar as necessidades pra estar intervindo junto aos profissionais. Então, nesse ano, nós tivemos textos que foram propostos pela secretaria, porém eu também identifiquei a necessidade de focar minhas formações em metodologia tanto de alfabetização como de matemática. Então eu busquei materiais, eu busquei materiais pra estar trabalhando com as professoras assuntos relacionados à metodologia. Nós discutimos atividades, nós conversamos sobre a pertinência de determinado trabalho, de determinada atividade, do que é bom do que não é bom. Foi assim. Às vezes é uma coisa que é unificada pra rede toda, e agora a gente tem a autonomia de poder identificar a necessidade da escola e a própria coordenadora da unidade preparar o material.

Entrevistadora: Pra gente encerrar, fale um pouco sobre a proposta de estudos com relação às avaliações externas.

CPSC: Bom, esse ano, como já foi falado, novembro é o mês das avaliações externas. O segundo ano vai fazer provinha Brasil, se bem que a provinha Brasil é uma avaliação interna, mas é proposta pelo Governo Federal. Provinha Brasil e Saresp, o terceiro ano vai fazer ANA e Saresp, $5^{\circ}$ ano vai fazer prova Brasil e Saresp. Então só o primeiro e o quarto que não vão fazer avaliações. Então, a nossa atuação em relação às nossas formações, estão mais relacionadas ao referencial de conteúdo que será abordado nas avaliações. Se bem que são conteúdos que já são trabalhados na prática, já fazem parte do currículo da criança, mas trabalhos mais voltados pros referenciais, que tipo de habilidade, que tipo de conteúdo que vai ser cobrado nessas avaliações, o tipo de questão que vai cair pra estar repassando isso pros alunos. A gente não treina, não ficamos só nisso. As professoras do quinto ano, em ano de prova Brasil, elas focam o trabalho delas de língua portuguesa e de matemática na prova Brasil, porém, nesse trabalho elas abordam todo o conteúdo que elas têm que trabalhar com a classe. Assim, elas não ficam presas ao material, ao referencial que tem, elas vão diversificando de acordo com a sala delas. E, assim, pras professoras, o que é importante no meu ponto de vista do que a gente vem fazendo. Nós fazemos uma análise desse referencial, que tipo de conteúdo vai ser cobrado nessas avaliações, fazemos uma análise do tipo de atividade, quais as características das atividades. Elas preparam atividades em cima desses referenciais que vem de provas anteriores, que a gente já vem trabalhando com as crianças. Agora a gente vai entrar, na semana que vem... Hoje mesmo eu passei pra elas o documento da avaliação ANA, como já tinha falado, hoje eu tive uma formação 
só com o terceiro ano, já passei pra elas as características da avaliação, que conteúdos serão cobrados, aí já perguntei pra elas que conteúdos elas trabalharam, o que elas ainda não trabalharam, sobre o quarto bimestre, pra elas já darem uma introduzida, pra que as crianças tenham condição de fazer a avaliação. Agora na próxima semana eu já vou estar mais assim com a sistemática de aplicação mesmo, porque as professoras de segundo, terceiro e quinto aplicarão SARESP, então elas terão que saber aplicar, e é uma série de regras que tem que ser seguidas, que aí a gente vai estar analisando os manuais de aplicação.

Entrevistadora: Esse estudo foi feito durante o ano todo ou agora, mais recentemente. CPSC: Olha, Prova Brasil foi o ano todo. Agora em relação ao SARESP, à Provinha Brasil, desde o começo do ano, agora no final do ano, nós começamos a voltar, assim pro SARESP. Assim, trabalhamos reflexões mesmo sobre como o professor iria intervir na sala de aula pra que as crianças avancem, atinjam determinado objetivo proposto. É isso que é feito.

Entrevistadora: Obrigada! 
Anexo 3

Questionário aplicado aos professores do Ensino Fundamental dos três sistemas de ensino

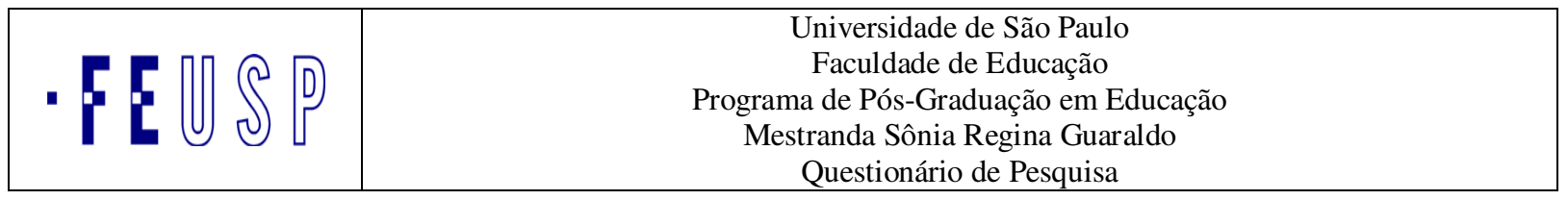

\begin{tabular}{|c|c|}
\hline \multicolumn{2}{|l|}{ DADOS PESSOAIS } \\
\hline Nome (opcional) & $\begin{array}{l}\text { Idade: } \\
\text { Sexo: } \mathrm{M}(\text { ) } \mathrm{F}(\mathrm{)}\end{array}$ \\
\hline \multicolumn{2}{|c|}{ Função: ( ) Professor efetivo ( ) Professor contratado temporariamente } \\
\hline Possui Curso de Magistério em Nível Médio? Sim ( ) & Não ( ) \\
\hline \multicolumn{2}{|c|}{ Possui curso de Licenciatura? Sim ( ) Não ( ) } \\
\hline \multicolumn{2}{|c|}{ Em caso de resposta afirmativa qual (is) licenciatura (as) cursou? } \\
\hline \multicolumn{2}{|c|}{$\begin{array}{l}\text { Possui curso de Pós-Graduação? Sim ( ) Não ( ) } \\
\text { Em caso de resposta afirmativa qual (is) Pós-Graduação cursou? }\end{array}$} \\
\hline \multicolumn{2}{|l|}{ Há quanto tempo você é professor (a)? } \\
\hline \multicolumn{2}{|l|}{ Há quanto tempo você trabalha nesta escola? } \\
\hline \multicolumn{2}{|c|}{ 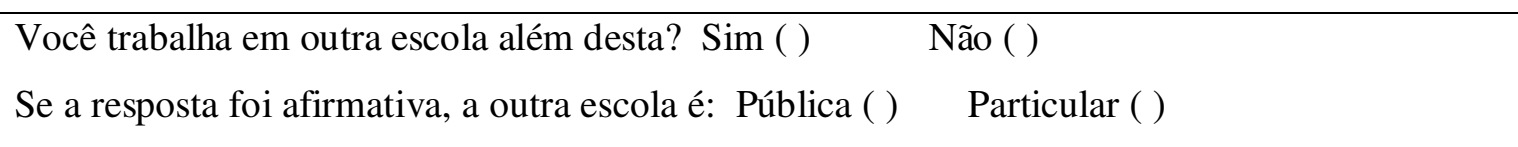 } \\
\hline \multicolumn{2}{|l|}{ Formação Continuada em Serviço } \\
\hline \multicolumn{2}{|l|}{$\begin{array}{l}\text { 1- Meus conhecimentos pedagógicos atuais se devem mais: } \\
\text { ( ) À minha prática e aos cursos realizados } \\
\text { ( ) Ao meu curso de graduação } \\
\text { ( ) outra }\end{array}$} \\
\hline \multicolumn{2}{|c|}{$\begin{array}{l}\text { 2- Qual das afirmações abaixo mais se encaixa na avaliação que você faz dos cursos oferecidos. } \\
\text { ( ) São muito teóricas e não se relacionam com a realidade da escola. } \\
\text { ( ) Apresentam apenas receitas prontas, sem explicar o porquê das coisas. } \\
\text { ( ) outra }\end{array}$} \\
\hline
\end{tabular}


3- O que considera mais relevante no enfrentamento dos desafios pedagógicos.

( ) O trabalho individual e coletivo na escola

( ) A ajuda externa possibilitada pelos cursos

( ) Outra

4- Com que freqüência você participa dos cursos de formação continuada oferecidos pelo município?

( ) sempre

( ) às vezes

5- Qual o principal fator que te motiva a participar de um curso de formação?

6- Em que período do ano considera mais adequado a realização de cursos de formação.

( ) Em períodos de férias/ recesso escolar

( ) No decorrer do ano

7- Em sua opinião, qual o formato de cursos é o mais adequado para a formação continuada? Por quê?

8- Que temas/áreas do conhecimento devem ser abordados nos cursos de formação?

9- Em sua opinião, um professor que procura aperfeiçoamento profissional:

( ) Deve obter benefícios na carreira.

( ) Não deve obter benefícios na carreira.

( ) Outra

10- Se os cursos oferecidos pela Secretaria de Educação não fossem contados para a progressão funcional, você:

( )Participaria

( )Não participaria. 